\title{
A Regulatory Guide to Leasing, Permitting, and Licensing in Idaho, Montana, Oregon, and Washington
}

by

Joyce Deshaye

Washington State Energy Office

Principal Investigator

R. Gordon Bloomquist, Ph.D.

Prepared by the Washington State Energy Office in cooperation with the Oregon Department of Energy and the Idaho Department of Water Resources

for

The Bonneville Power Administration Agreement No. DE-BI79-91BP16067 


\section{Disclaimer}

This publication was prepared for use by interested developers and the Bonneville Power Administration. Neither the Bonneville Power Administration, nor the United States Department of Energy, nor the Washington State Energy Office, nor any of their employees, nor any of their contractors, subcontractors, or their employees, makes any warranty, expressed or implied, or assumes any legal liability or responsibility for the accuracy, completeness, or usefulness of any information presented. The views and opinions of authors expressed herein do not necessarily state or reflect those of the United States Government or any agency thereof. Reference herein to any specific product, process, or service by trade name, mark, manufacturer, or otherwise, does not necessarily constitute or imply its endorsement, recommendation, or favoring by the United States Government or any agency thereof.

Please be aware that information included in this guide is subject to change. The Washington State Energy Office and Bonneville Power Administration are not to be held responsible for information that has changed since the printing of this guide. New laws are developed and old laws are altered or repealed during each legislative session. Agencies may update their administrative codes, increase fees, or reorganize.

Also, there are resource protection requirements that are not listed in this guide. Requirements issued by special districts, such as sewer and water, diking, irrigation, port districts, etc., are not addressed herein. Some requirements may have been inadvertently left out, and in some cases, state agencies chose not to include those requirements that would apply only in rare cases.

The only way to be absolutely sure about permit requirements that apply to your project is to contact the appropriate federal, state, and local agencies.

\section{Acknowledgements}

The Bonneville Power Administration and the Washington State Energy Office would like to pay special thanks to the following people for their help in preparing this guidebook: R. Gordon Bloomquist, Ph.D. of the Washington State Energy Office; Alex Sifford of the Oregon Department of Energy; Paul Cartwright of the Montana Department of Natural Resources and Conservation; Rick Sterling of the Idaho Department of Water Resources; and to Jack Feuer of the Bureau of Land Management. Special thanks and appreciation go to Char Gruessing of the Washington State Energy Office who helped to coordinate the information and was responsible for the word processing of this book. 


\section{Table of Contents}

\section{Introduction}

Organization

Cogeneration History and Technology …………………......................

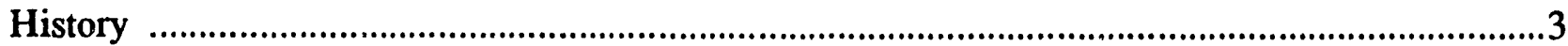

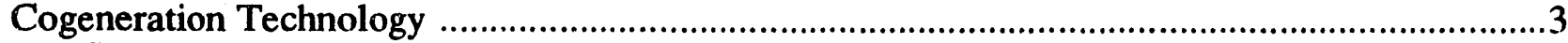

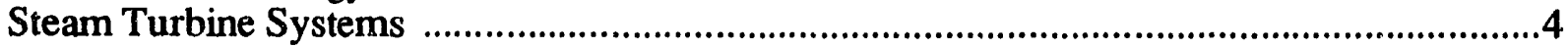

Gas Turbine Systems .......................................................................................................

Combined-Cycle Systems ..................................................................................................10

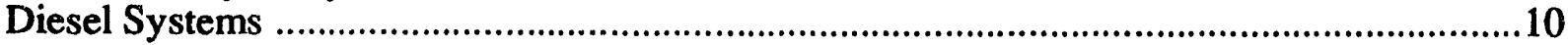

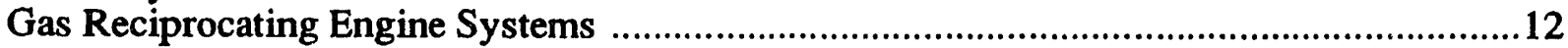

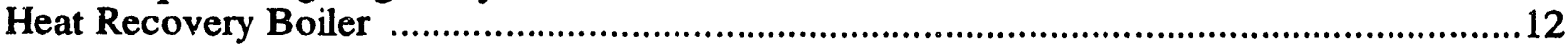

Chapter 1 - The Federal Process .........................................................13

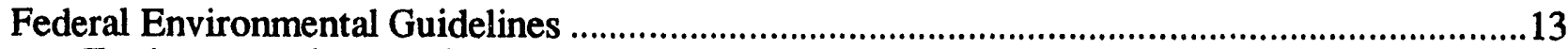

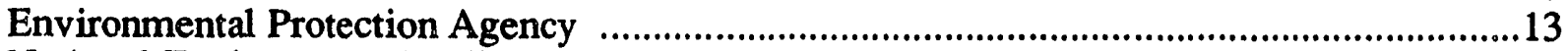

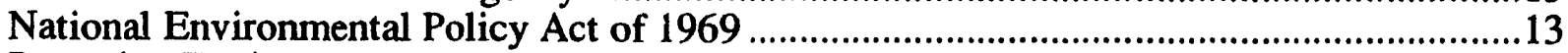

Preparing Environmental Impact Statements .....................................................................14

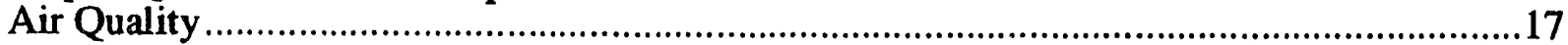

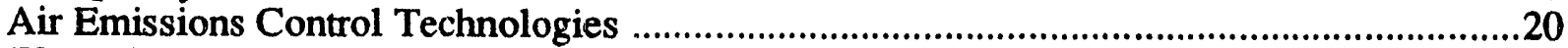

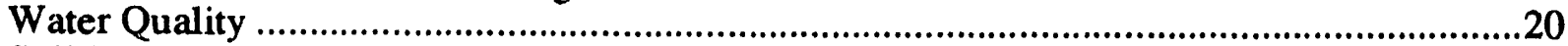

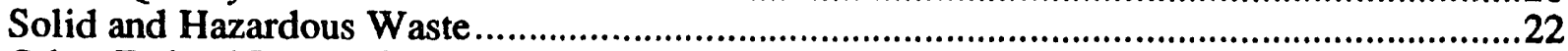

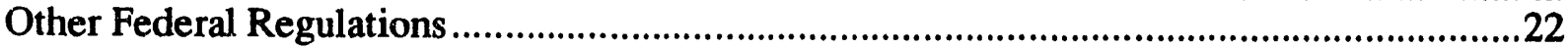

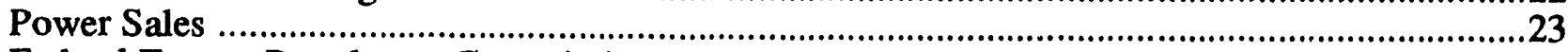

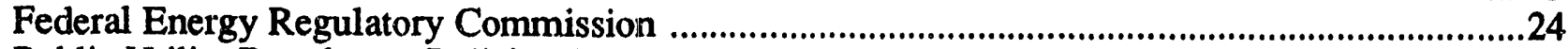

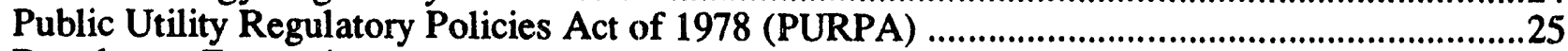

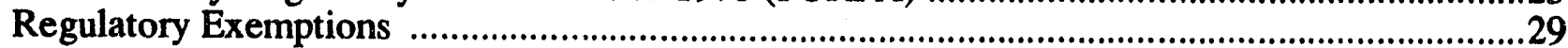

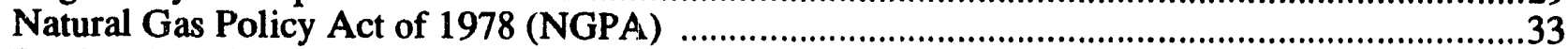

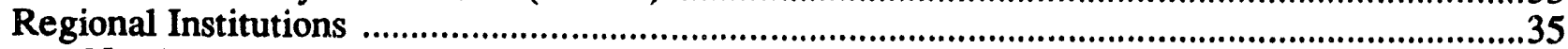

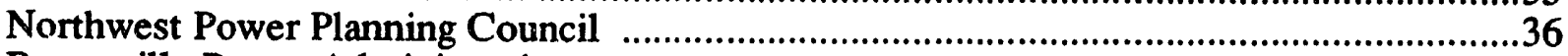

Bonneville Power Administration ...................................................................................37

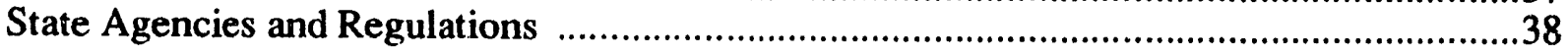

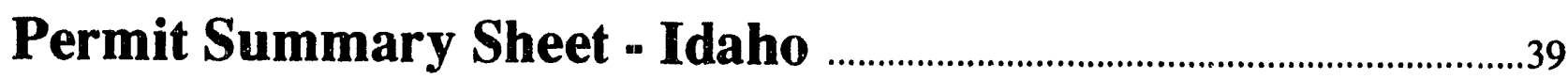

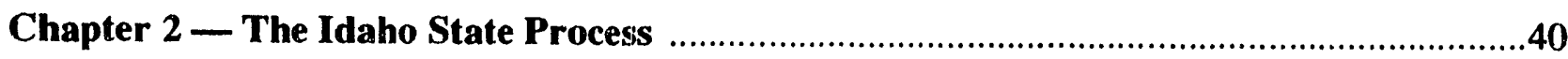

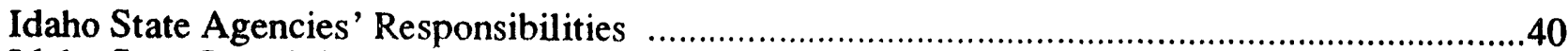

Idaho State Permitting and Licensing Requirements ..............................................................43

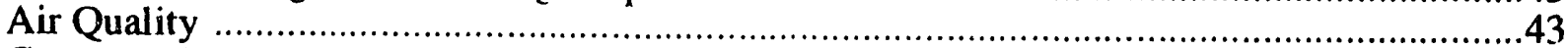

Cogeneration Facility Siting/Environmental Impact ..........................................................46

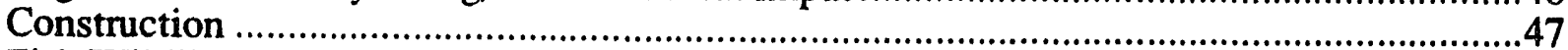

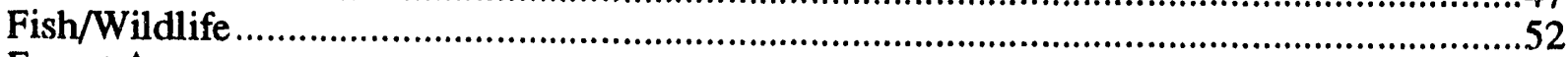

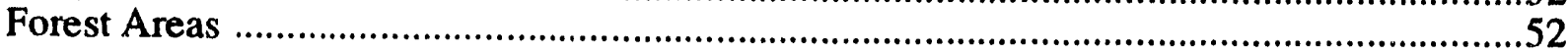


Land Use

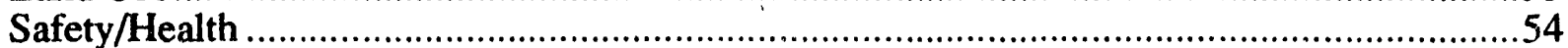

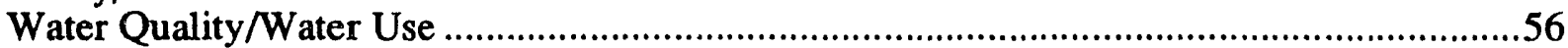

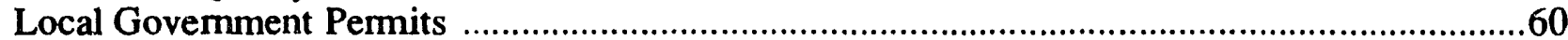

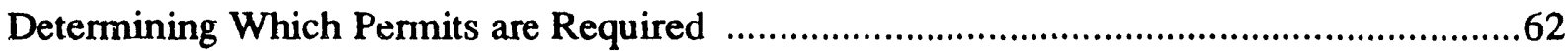

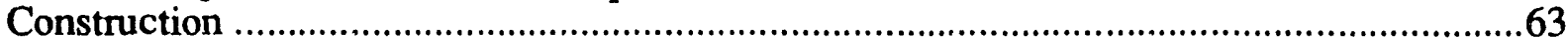

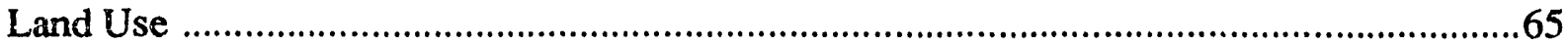

Safety/Health .................................................................................................................67

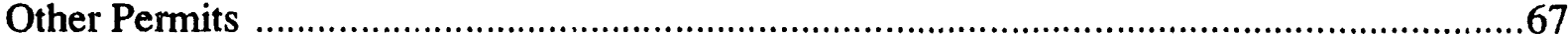

\section{Permit Summary Sheet — Montana …………………………………...69}

Chapter 2 - The Montana State Process …………………………...70

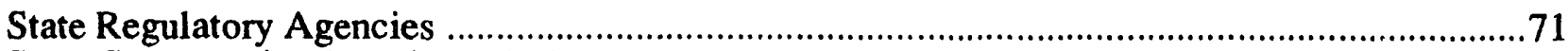

State Cogeneration Permits and Licenses .............................................................................

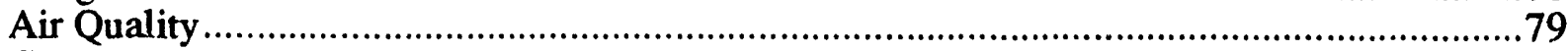

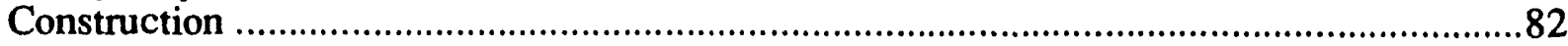

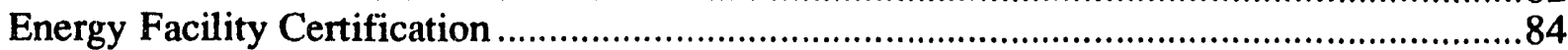

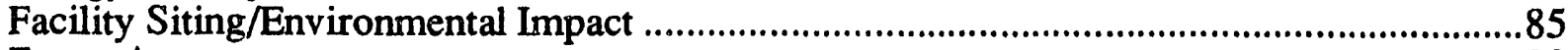

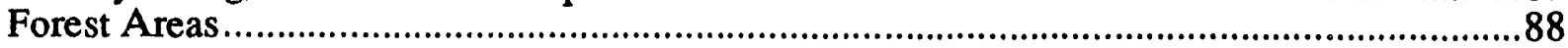

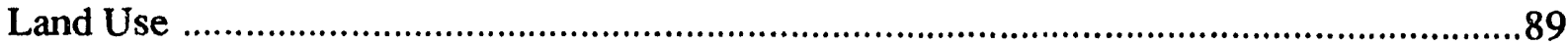

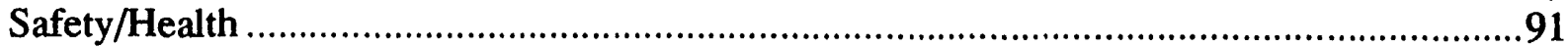

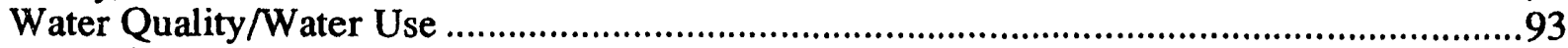

Local Permitting and Licensing Requirements .........................................................................96

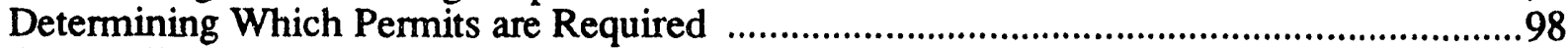

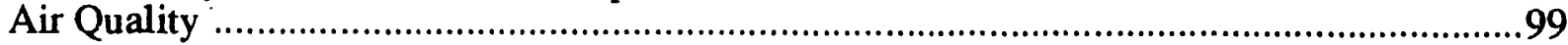

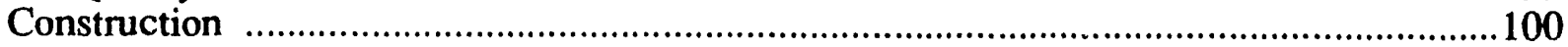

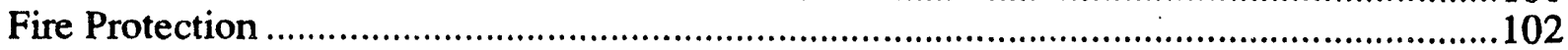

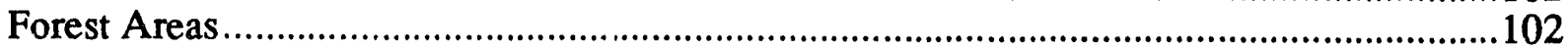

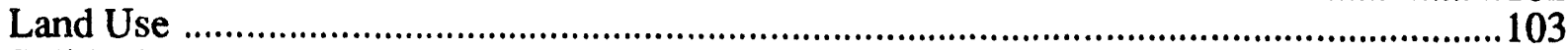

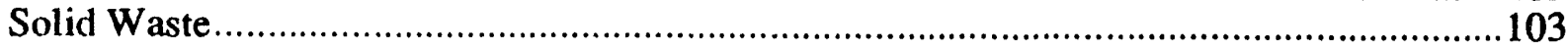

Permit Summary Sheet - Oregon ...............................................................105

Chapter 4 - The Oregon State Process ……......................................106

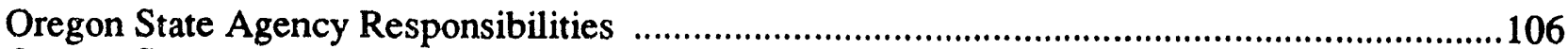

Oregon State Permitting and Licensing Regulations ........................................................111

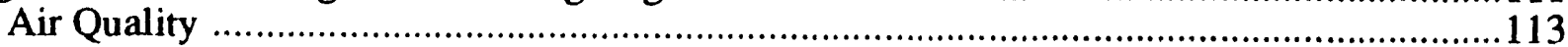

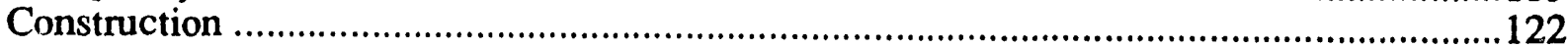

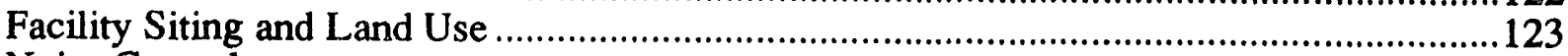

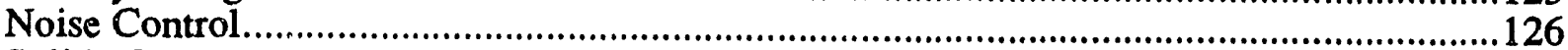

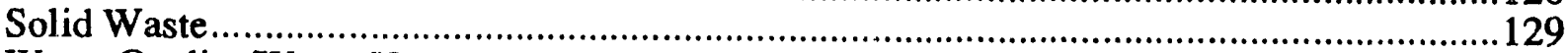

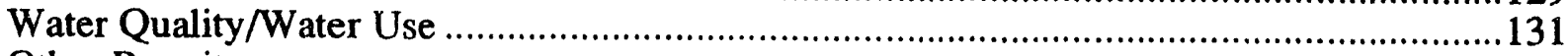

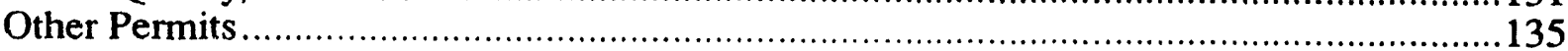

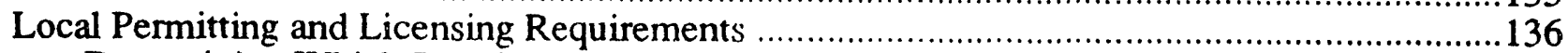

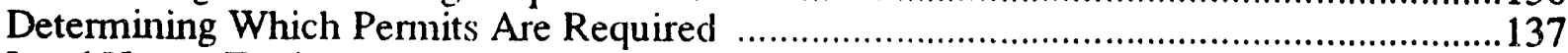

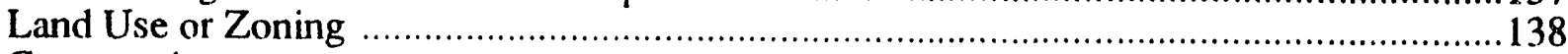

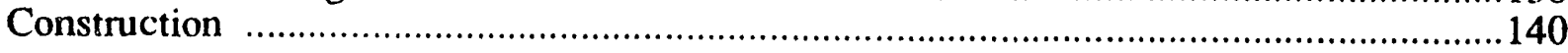




\section{Permit Summary Sheet — Washington ……………………………...141}

Chapter 5 - The Washington State Process .................................142

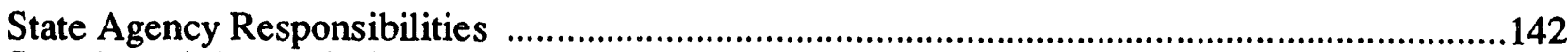

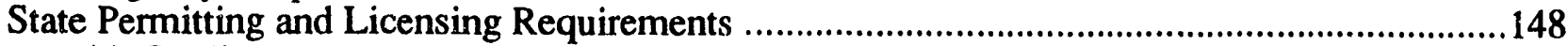

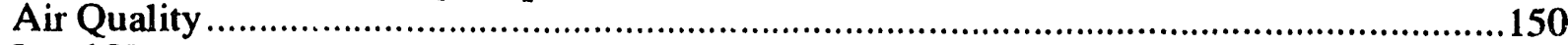

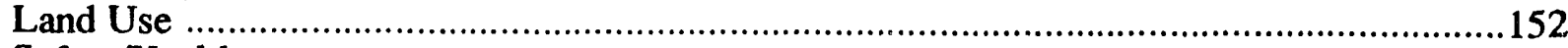

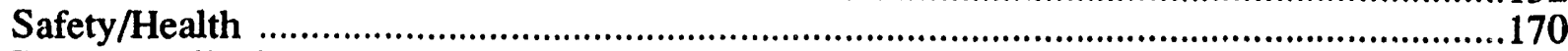

Water Quality/Water Use .....................................................................................172

Local Permitting and Licensing Requirements ..................................................................176

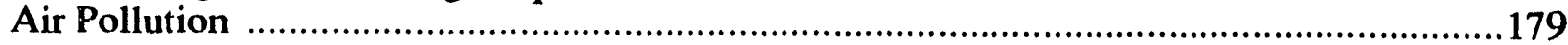

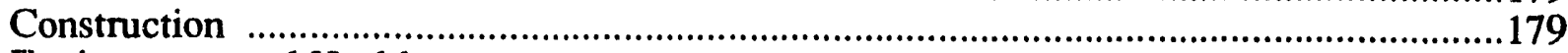

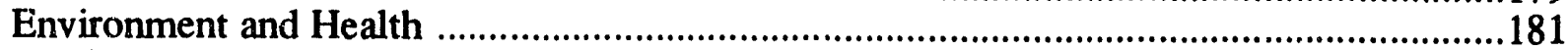

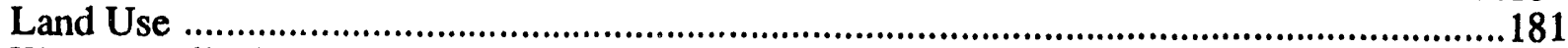

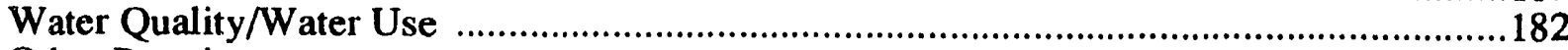

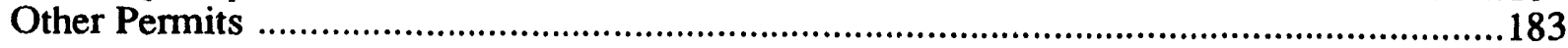

Glossary

\section{Appendices}

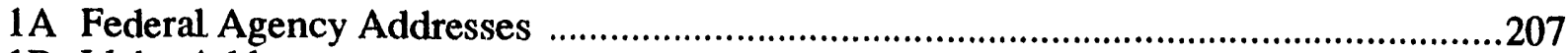

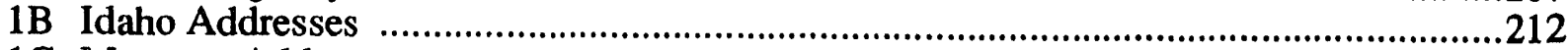

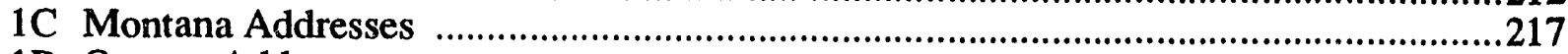

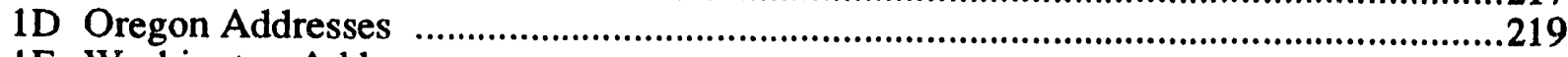

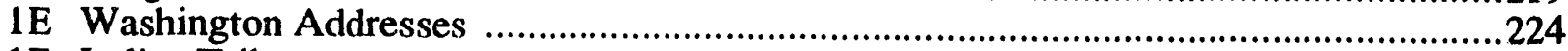

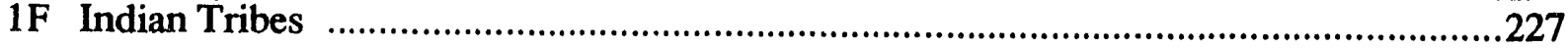




\section{Listing of Tables}

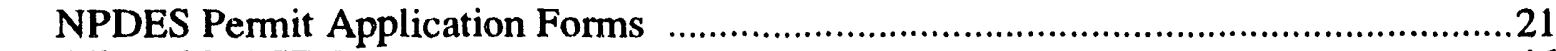

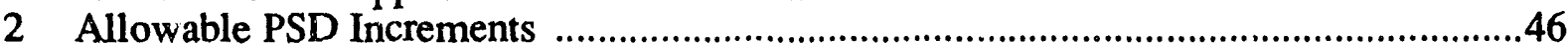

3 Some Air Pollutants Regulated by the State of Montana ……………..............................

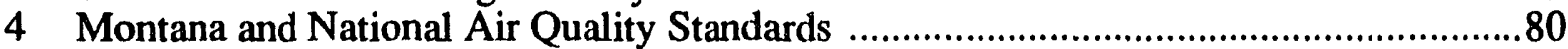

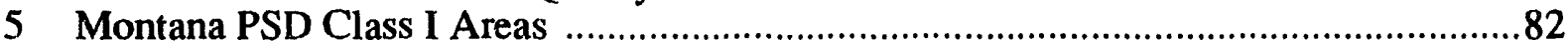

6 Do You Need a Permit? Or Do You Need to Notify Authorities? .................................112

7 Summary of Air Quality Permits ...............................................................................113

8 Emission Standards and Regulations Included in an Air Contaminant Discharge Permit (ACDP) .............................................................115

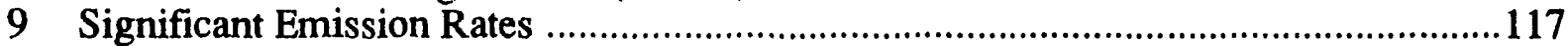

10 Specific Emission Rates in Medford-Ashland AQMA ............................................117

11 Sources Which Require a SERP ........................................................................118

12 New Source Performance Standards .....................................................................120

13 Maximum Pollutants Levels Allowed by PSD Rules ……...................................120

14 PSD Allowable Increments-Maximum Allowable Increase in

Pollution Levels in Micrograms per Cubic Foot ....................................................121

15 Titles of LCDC Statewide Planning Goals ……...................................................125

16 When to Submit Land Use Compatibility Statements …………….........................126

17 New Industrial and Commercial Noise Source Standards .........................................127

18 Industrial and Commercial Noise Source Standards for Quiet Areas ..........................127

19 Median Octave Band Standards for Industrial and Commercial Noise Sources ...........128

20 Do You Need a Solid Waste Permit? ........................................................................130

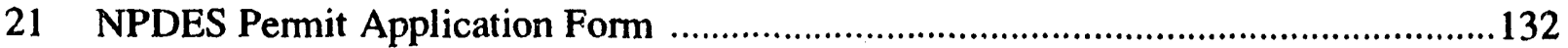

22 Environmental Coordination Procedures Act (1973) —Coordination Permits .............144

23 Do You Need a Permit? Or Do You Need to Notify Authorities? ................................148

24 Possible State Permits or Evaluation Required for Development of a

Cogeneration Project

\section{Listing of Figures}

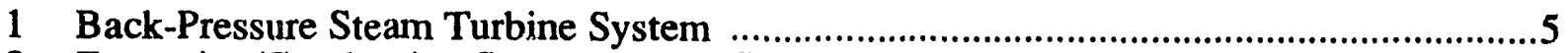

2 Extraction/Condensing Steam Turbine System ….....................................................

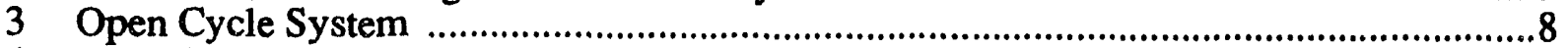

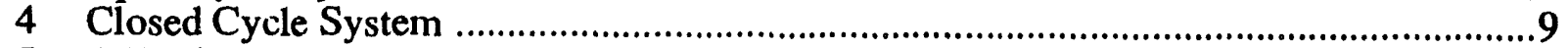

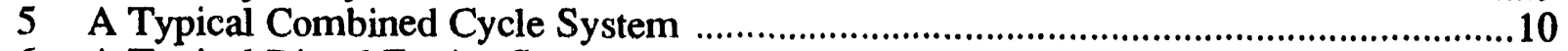

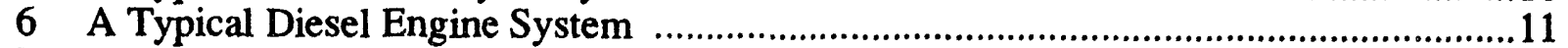

7 Calendar for Timing Typical Permits ....................................................................112

8 Oregon's Air Quality Regions and Air Quality Maintenance Areas .............................114

9 Energy Facility Siting Council Application Process Diagram ...................................124

10 Local Govermment Land Use Approval-Land Use Planning and Permit Process .....139

11 WEFSEC Certification Process ………………......................................................156

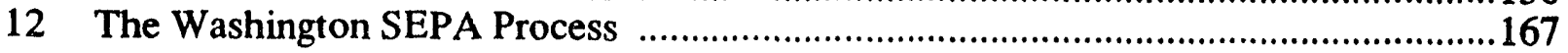




\section{Introduction}

This guidebook focuses on cogeneration development. It is one of a series of four guidebooks recently prepared to introduce the energy developer to the federal, state and local agencies that regulate energy facilities in Idaho, Montana, Oregon, and Washington (the Bonneville Power Administration Service Territory). It was prepared specifically to help cogeneration developers obtain the permits, licenses and approvals necessary to construct and operate a cogeneration facility.

The regulations, agencies and policies described herein are subject to change. Changes are likely to occur whenever energy or a project becomes a political issue, a state legislature meets, a preexisting popular or valuable land use is thought threatened, elected and appointed officials change, and new directions are imposed on states and local governments by the federal government.

Accordingly, cogeneration developers should verify and continuously monitor the status of laws and rules that might affect their plans. Developers are cautioned that the regulations described herein may only be a starting point on the road to obtaining all the necessary permits.

\section{Organization}

The first chapter will briefly describe cogeneration technologies and emissions control. It will also introduce the reader the Environmental Protection Agency (EPA) and to important environmental regulations impacting cogeneration. Readers will leam about how cogeneration facilities can become qualified as small power producers opening the doors to marketing excess power. It will explain the Federal Energy Regulatory Commission-an important federal agency having impact on the sale of energy from cogeneration facilities. It will describe the regional agencies-the Northwest Power Planning Council and Bonneville Power Administration. A cogeneration developer should become very familiar with these agencies and set up channels of communications with these agencies as they will keep you abreast of important federal legislation concerning energy production.

Chapters 2, 3, and 4 provide cogeneration regulations, permits, licenses and other approvals for the states of Idaho, Montana, Oregon, and Washington.

Important terms and abbreviations can be found in the glossary at the end of the book (page 185). Federal, state, and some local agencies' addresses and telephone numbers are listed in the Appendix (pages 207 through 230). 


\section{Cogeneration History and Technology}

Cogeneration is a technology that can produce electric, thermal and mechanical energy for industrial, commercial, heating, or cooling purposes, through the sequential use of a single energy source. Cogeneration facilities' overall efficiencies are much higher than for systems which produce electrical and thermal energy separately. Increased efficiencies result in reduced fuel requirements, offering a significant energy-savings potential and making industrial facilities less dependent on foreign oil.

\section{History}

Cogeneration can be traced to the earliest days of the electric power industry. In the early 1900 's, many U.S. industrial plants generated their own electricity, and practiced cogeneration by using the exhaust steam for process heat. When the price of utility-provided electricity became cheaper, more widely available, and more reliable, industry gradually shifted away for onsite electrical generation, by 1979, on-site generation accounted for less than four percent of U.S. power generation.

Significant changes in the availability and costs of energy over the past two decades have resulted in an increased emphasis on energy conservation and efficiency in energy intensive commercial and industrial facilities. Growing electricity demand and energy shortages have increased the attractiveness of cogeneration and have taken it from an almost nonexistent industry to a growth industry.

Until recently, industrial facilities provided for the most successful cogeneration applications. Their demands for electricity and thermal energy were fairly constant, and the facilities were large enough so investors could benefit from economies of scale. However recent energy trends, government policies, and technological advancements have made cogeneration more attractive to commercial and institutional building owner as well. More and more facilities are looking into cogeneration as a profitable investment that can provide greater ability to control both energy costs, a stable source of electric power, and has the potential of increasing revenues by marketing excess power.

\section{Cogeneration Technology}

Cogeneration is defined as the utilization of waste energy by a commercial or industrial facility to produce both electrical and thermal energy simultaneously from a single energy source. Cogeneration systems recapture otherwise wasted thermal energy. Their overall efficiencies are much higher than for systems which produce electrical and thermal energy separately. Increased efficiencies result in reduced fuel requirements, offering a significant energy-savings potential. 
Self-generation is the method by which a facility generates some or all of their electricity and thermal energy (often steam) requirements from a cogeneration/small power plant located onsite. Facilities generating their own electricity are not dependent on electric grid, isolated from future electric rate increases, isolated from brown outs/power shortages, and can provide for cost effective disposal of waste. Therefore, the goal of a cogeneration project is to develop a selfgenerating energy facility that provides, over the long-run, a reliable source of low-cost energy.

Cogeneration technologies are generally classified as either topping or bottoming cycle systems the most common cogeneration mode is the topping system. In this system electricity is produced first. The remaining thermal energy, in the form of steam or hot water, is available for commercial and industrial applications. The main types of topping systems include: steam turbines, gas turbines, combined cycle, and diesel and gas reciprocating engines.

Bottoming cycle technology first produces high temperature thermal energy, such as in a blast fumace, then the waste heat is channeled through a recovery boiler and a steam turbine to procure electricity. Bottoming system applications are currently limited to industries that need high temperature heat, such as the aluminum and steel industries.

\section{Steam Turbine Systems}

Steam turbine systems have been used extensively by industry for many years. The technology is proven and well understood. In this type of system, fuel is bumed in a boiler to generate steam at pressures between 600 and $1,450 \mathrm{psi}$ and at temperatures ranging from $750^{\circ} \mathrm{F}$ to $950^{\circ} \mathrm{F}$. Steam is then expanded through a turbine, and electricity is produced when the rotating turbine turns a generator motor. The steam generally leaves the turbine at a reduced pressure between 50 and $600 \mathrm{psi}$, and at temperatures ranging from $300^{\circ} \mathrm{F}$ to $700^{\circ} \mathrm{F}$. The steam is then available for direct use in plant processes.

The types of steam turbines used in cogeneration systems include back-pressure extraction/noncondensing, and extraction/condensing (Figures 1 and 2). The back-pressure turbine exhausts steam at a pressure and temperature appropriate for the process heat requirements of the plant. While at these turbines are typically less capital intensive than the extraction units, they have a fixed electricity to steam ratio and cannot adjust well to steam or electric load fluctuations. If plant requires more than one type of steam for its processes and extraction/non-condensing turbine may be applicable. These turbines can provide both high pressure steam from an intermediate extraction port or ports and low pressure exhaust steam.

When the plant's steam and electric loads vary significantly, extraction/condensing turbines may be utilized. In this type of unit, steam is extracted at one or more ports at intermediate pressures and temperatures, while all of the exhaust steam is condensed. These turbines offer considerable flexibility in adjusting the ration of electricity to steam produced. If process steam loads are 


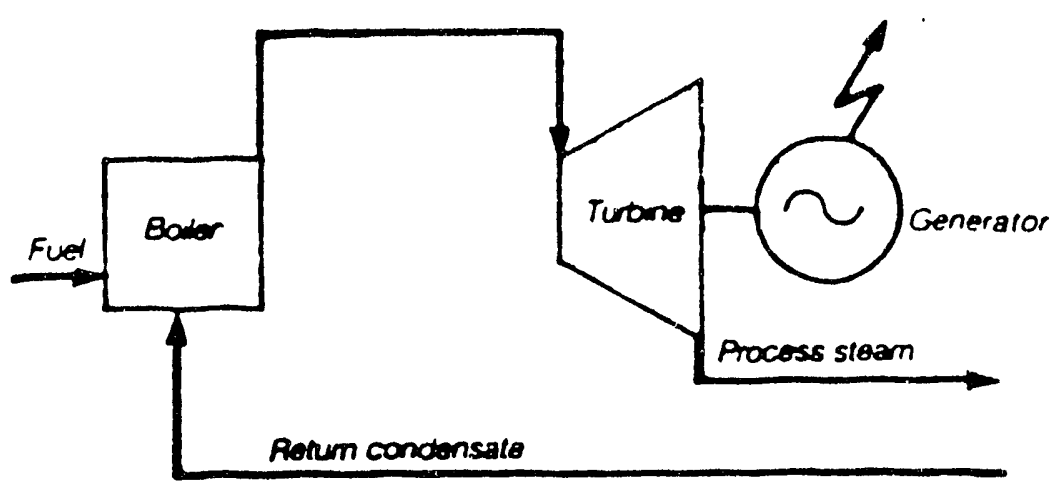

Figure 1: Back-Pressure Steam Turbine System

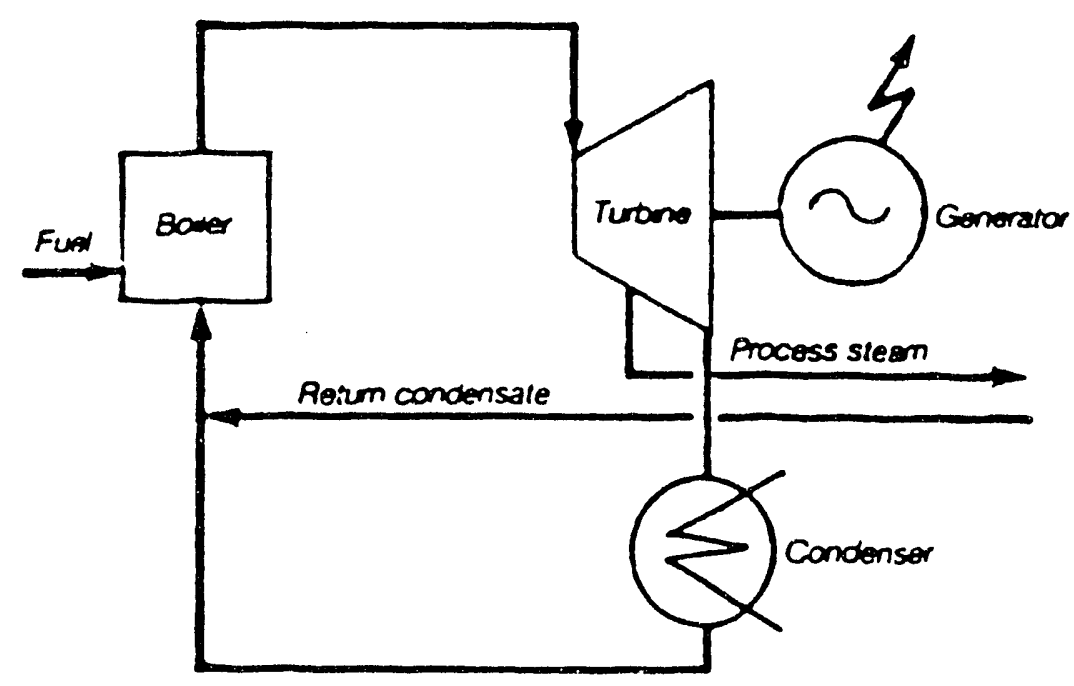

Figure 2: Extraction/Condensing Steam Turbine System

large, high extraction is appropriate. When steam loads are low, most or all of the steam can be directed to the condenser to increase the electricity produced. It should be noted, however, that the fuel utilization, or overall efficiency of the system, is highest when steam extraction is highest.

Steam turbines can also be classified as either single or multi-stage units. Although generally less expensive, single stage turbines may suffer a considerable loss of efficiency under partial loading conditions. Multi-stage turbines, on the other hand, are able to maintain higher efficiencies since they have reasonably flat efficiency curves. 


\section{Steam Turbine Systems Air Emission Control Technologies}

Fossil fuel steam generators used in producing electricity or process steam are major sources of air pollution and can also produce significant amounts of water pollutants and solid waste. Air pollutants produced during combustion in fossil fuel boilers include total suspended particulates, sulfur dioxide, and nitrogen oxides. Emission control systems for steam generating units are described in the following sections.

\section{Particulate Emissions Controls}

Particulate emissions are caused of the ash content of fuels, which can range from 5 to 15 percent in coals depending upon their geographic origin. Residual oil contains less than 1 percent ash while distillate oil and natural gas contains trace amounts. There are four types of pollution control devices used to capture these particulates. They are electrostatic precipitation, fabric filters, wet scrubbers and multitube cyclones.

\section{Electrostatic Precipitators}

Electrostatic precipitators (ESP) are characterized by a collection efficiency in excess of 99 percent, and have moderate operating costs compared with the other three systems. They are also adaptable to small boilers. However, the greatest efficiency is obtained with larger systems, such as utility boilers. Variations in fuel characteristics, such as sulfur and alkali content and particle size can play an important role in determining ESP performance. These variations are more common in industrial boiler fuels than in utility boiler fuels. Industrial boiler operators usually purchase coal on the "spot" market rather than obtaining it through long-term commitments as do utilities. In addition, load levels are more constant arid shutdowns are less frequent for utility boilers. Field tests of ESP performance have ranged from 97.0 to 99.8 percent removal for utility boilers. Emission levels have been measured at 0.01 pounds per million Btu heat input. Which is an emission limit set by many states. For oil-fired boilers, ESP efficiency can vary from 45 to 90 percent, but these units are not normally used for new installations. They are being used in oil-fired boilers that originally used coal. With no modifications, an ESP unit originally designed for coal and now used on an oil-fired boiler may only provide an efficiency of approximately 50 percent.

\section{Bag Houses}

Fabric filtration or "bag houses" for industrial coal-fired boilers account for approximately 10 percent of the market for particulate controls. Collection efficiencies of 96 to over 99 percent with emission rates of 0.01 to 0.046 pounds per million Btu have been achieved. Major factors affecting boilers equipped with fabric filters are additional maintenance requirements, potential corrosion problems, and transient operations. Fabric filters are not normally used for oil-fired units because of potential damage to filters from the hydroscopic charter or oil fly ash. Under the stringent level of emission control fabric filters are more cost effective than ESP when lowsulfur coals are used. 


\section{Wet Scrubbers}

The use of wet scrubbers for coal-fired boilers has several advantages and disadvantages. The major advantages are the ability to remove both particulates and gases; the ability to function in a wet, corrosive, and explosive gas atmosphere; and less space requirements than either ESP or fabric filters. Some of the major disadvantages are: energy penalties associated with their operation; poor efficiency for fine particulates; potential water and solid waste problems; and highpressure loss at equivalent ESP or fabric filter collection efficiencies. A major factor affecting scrubber performance is the non-steady state operation of industrial boilers, although, high particulate-removal efficiency can be achieved once a steady state is reached. Collection efficiencies of 98 percent are achievable even if the mass emission rate may exceed standards due to inability to remove fine particulates. Wet scrubbers are not usually used on oil-fired boilers since oil particulates are usually less then 2 microns, which are not readily captured.

\section{Multitube Cyclones}

Mechanical collectors such as multitube cyclones have lower particulate removal efficiencies than the other devices previously described. Their performance is a function of aerosol particulate size, with particles over 10 microns most readily captured. Mechanical collectors are mostly used in conjunction with other control devices to improve efficiencies. By themselves, these systems have emission rates of 0.19 to 3.05 pounds per million Btu, which are higher than allowed by most state regulations.

\section{Sulfur Dioxide Emissions Control}

Sulfur dioxide $\left(\mathrm{SO}_{2}\right)$ emissions are a function of the sulfur content of fuel which can range from less than 0.5 percent for distillate oil to over 4 percent for high sulfur eastern coal. Several methods may be used to reduce $\mathrm{SO}_{2}$ emissions from industrial boilers to comply with current emission limits at the state level. Potential control methods are the use of low sulfur fuel, physical and chemicil coal cleaning, use of coal derived gases or liquids fluidized bed combustion, and flue gas desulfurization (FGD). The most effective means of $\mathrm{SO}_{2}$ control for corgeneration systems are low-sulfur fuel to meet state emission regulations. Low sulfur eastern coal and western sub-bituminous coals typically contain less than 1 percent sulfur which is adequate to meet emission regulations for several states.

\section{Nitorgen Oxide Emissions Control}

Nitrogen oxides $\left(\mathrm{NO}_{\mathbf{X}}\right)$ formed during combustion result from either thermal fixation of atmospheric nitrogen in the combustion air, or to the conversion of chemically bound nitrogen in the fuel. For natural gas and distillate oil firing, nearly all $\mathrm{NO}_{x}$ emissions result from thermal fixation, while with residual oil and coals, the contribution from fuel bound nitrogen can predominate. The rate of formation of both thermal and fuel $\mathrm{NO}_{\mathbf{x}}$ is highly dependent on combustion conditions, and both are promoted by rapid mixing of the oxygen with the fuel. In addition, thermal $\mathrm{NO}_{\mathbf{x}}$ is increased by long residence time at high temperatures. Control techniques to date are emphasizing combustion process modifications. The modifications, which are applicable to coal-, oil-, or gas-fired boilers, include: 
- low excess air (LEA)

- $\quad$ staged combustion air (SCA); over fire air or side fire air

- low $\mathrm{NO}_{\mathbf{x}}$ burners

- flue gas recirculation

- reduced air preheat

- load reduction or reduced combustion intensity

- ammonia injection

These techniques have varying effectiveness in reducing $\mathrm{NO}_{\mathrm{X}}$ emissions, and also have operational, cost, and environmental impacts.

\section{Gas Turbine Systems}

Gas turbine systems are classified as either open-cycle or closed-cycle units (Figures 3 and 4). Closed-cycle units differ from open-cycle units in that the air or other working fluid is recirculated. In the more common open cycle system, compressed air and a gaseous or high petroleum fuel are fired in a combustion chamber. The combustion gases, which can reach temperatures as high as $2,200^{\circ} \mathrm{F}$, are expanded through a turbine, and electricity is produced when the rotating turbine operates the attached generator. The gases exhausted from the turbine at temperatures of between $900^{\circ} \mathrm{F}$ and $1,100^{\circ} \mathrm{F}$ flow through a heat recovery boiler to generate steam or hot water for plant use. Since the turbine blades in an open cycle system are exposed to the impurities of the combustion pro-ducts, solid fuels such as coal and biomass cannot be burned due to their corrosive and erosive properties. In addition, residual oil and liquid or gaseous fuel from coal or biomass cannot be used unless an auxiliary fuel cleaning system is installed.

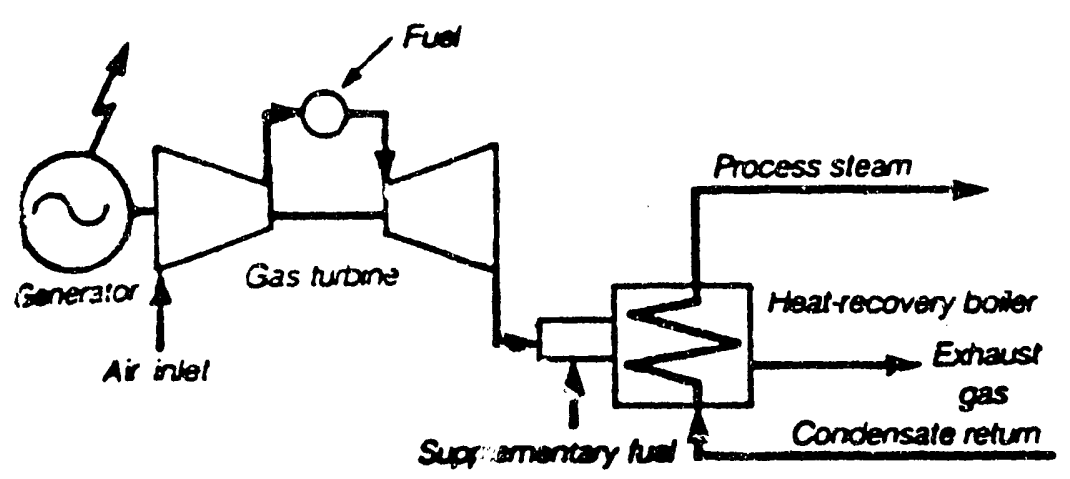

Figures 3: Open Cycle System 


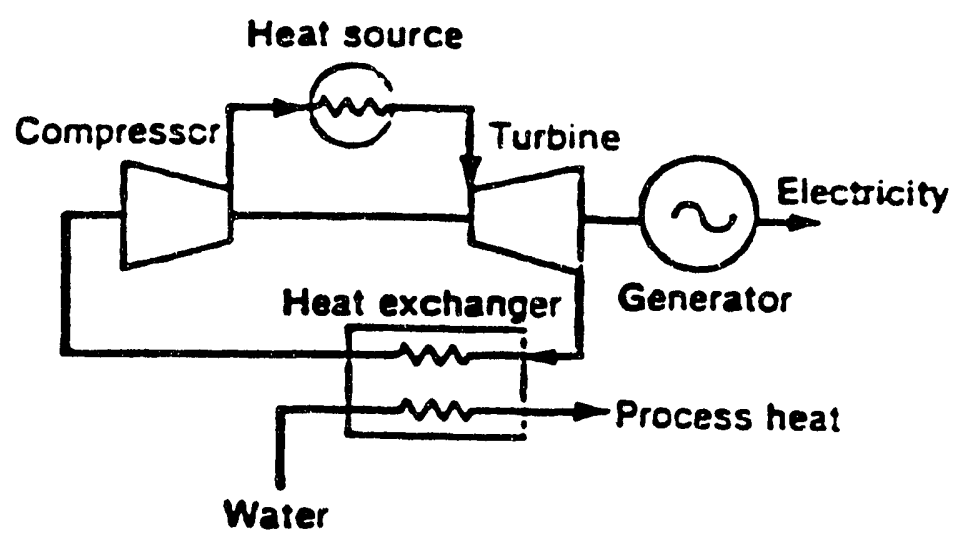

Figure 4: Closed Cycle System

In a closed cycle system, combustion takes place externally, and the recirculation working fluid usually helium or air, is brought to the inlet temperature by means of a heat exchanger. Thus, the turbine blades are never in contact with the corrosive/erosive combustion products. As a result, closed cycle systems can burn industrial or municipal solid wastes, biomass, and coal.

\section{Gas Turbine Systems Air Emissions Control Technology}

Gas turbines have limited environmental impact in that they produce some air pollutants, but have minimal generation of water pollutants, solid waste, and noise. The air pollutants of concern are nitrogen oxides and sulfur dioxide. New Source Performance Standards (NSPS) for stationary gas turbines were promulgated by EPA in September 1979 to regulate emissions of these pollutants. The emissions of particulates, hydrocarbons, and carbon monoxide are less significant with gas turbine systems.

Several basic techniques exist for reducing the formation of thermal $\mathrm{NO}_{\mathbf{x}}$ :

- reduce combustion pressure

- decrease peak flame temperatures in the combustor reaction zone

- reduce effective residence time of combustion gases at elevated temperature

- control the amounts of nitrogen and oxygen available for the production on $\mathrm{NO}_{\mathbf{x}}$.

Emissions control techniques for thermal $\mathrm{NO}_{\mathrm{x}}$ formation include wet systems consisting of water or steam injection, and dry systems consisting primarily of combustion modifications. The wet control techniques provide a heat sink which absorbs some of the heat of reaction, reducing peak 
combustion temperatures and the rate of $\mathrm{NO}_{\mathbf{x}}$ formation. Reductions in $\mathrm{NO}_{\mathbf{x}}$ emissions in excess of 80 percent have been achieved. Little difference in control efficiency has been found between water and steam injection, and both are accepted by industry as valid techniques for reducing $\mathrm{NO}_{\mathrm{X}}$ emissions. Wet control techniques also are not expected to affect turbine life, based on reported experience. A decreased of approximately 1 percent occurs in the overall efficiency of the turbine when water or steam injection is used.

\section{Combined-Cycle Systems}

A combined cycle system is usually an extraction/condensing unit (Figure 5). It is a variation of a gas turbine system in which the steam generated in the heat recovery boiler is used to drive a steam turbine. Supplementary firing may be necessary in the recovery boiler to achieve the needed inlet pressure and temperature for the steam turbine.

Combined cycle systems take advantage of the high electrical efficiencies of gas turbines coupled with the capabilities of extraction/condensing steam turbines.

\section{Diesel Systems}

Diesel cogeneration systems use the reciprocating internal combustion diesel engine as a prime mover (Figure 6). In a cogeneration mode, these engines are coupled with generators in order to produce electricity. Engine exhaust at temperatures around $800^{\circ} \mathrm{F}$ and the heat from the jacket cooling system are then directed to a waste heat recovery unit in order to produce steam and/or hot water.

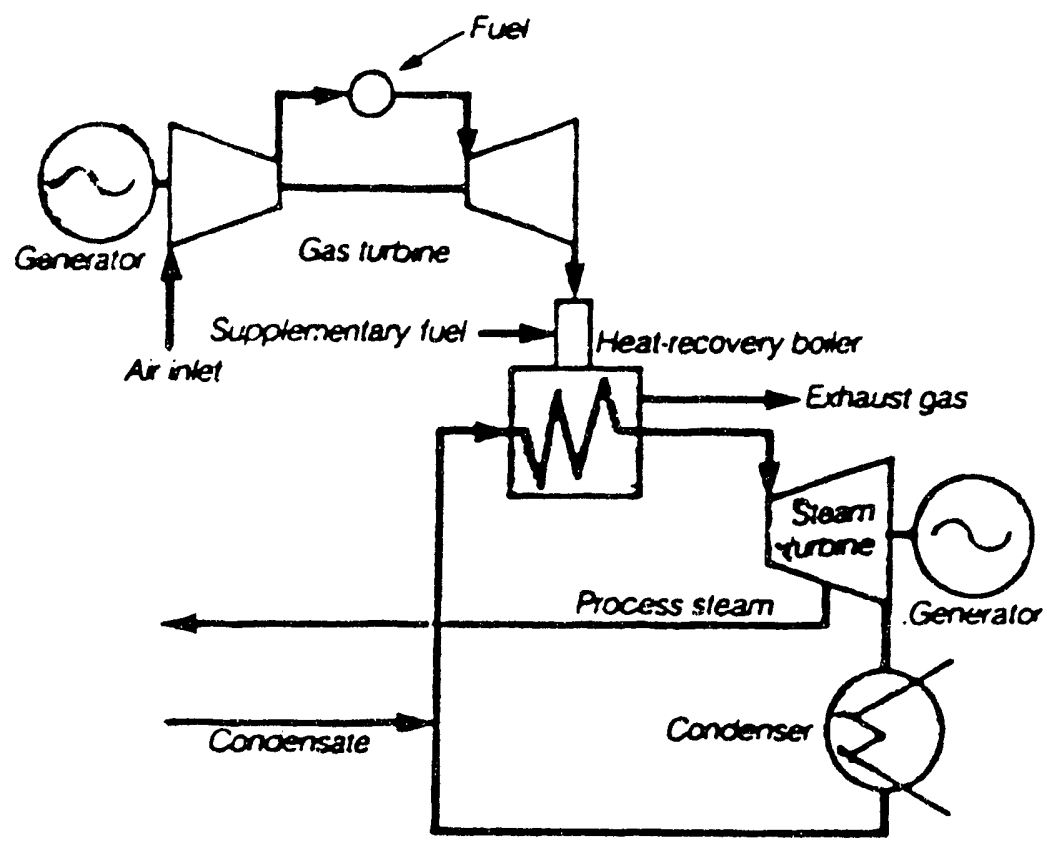

Figure 5: A Typical Combined Cycle System 


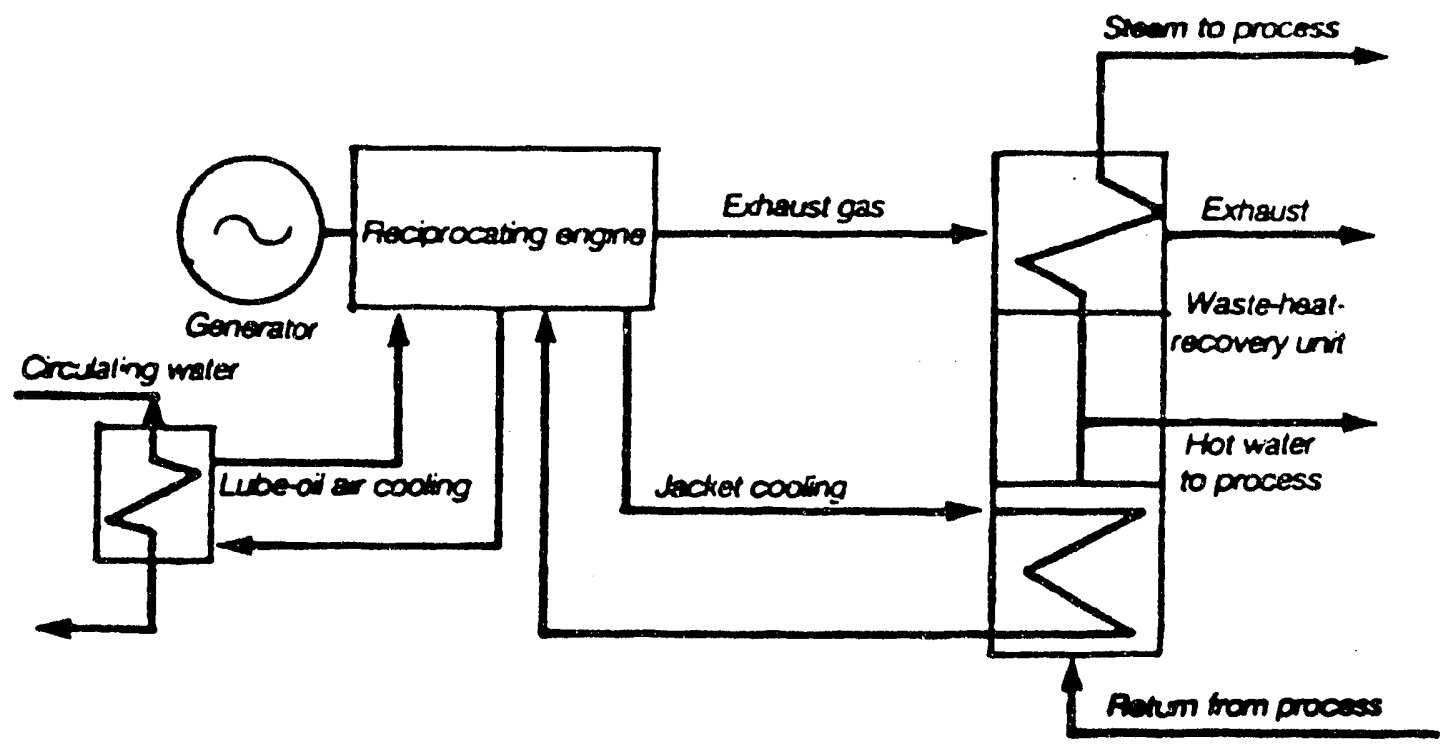

Figure 6: A Typical Diesel Engine System

Diesel engines are classified according to their speed of operation. High speed diesel engines operate between 1,201 and 3,600 revolutions per minute ( $\mathrm{rmm})$, and produce between 75 and $1,500 \mathrm{~kW}$ of electrical output. Medium speed diesel engines can produce from 0.5 to $10 \mathrm{MW}$, while operating at 500 to $1,200 \mathrm{rpm}$. Both high and medium speed diesels are four-cycle machines, which operate at approximately $200 \mathrm{psi}$. High speed diesels are generally ciesigned and used for vehicle propulsion, while medium speed diesels are generally designed and used for vehicle propulsion, while medium speed diesels are typically used in rail locomotive, or marine propulsion applications. Low speed diesel engines are two cycle machines which operate at approximately $120-180 \mathrm{rpm}$. The electrical output from these units ranges from 5 to $30 \mathrm{MW}$. They have historically been used for marine propulsion and for stationary electric power plants.

\section{Stationary Diesel Engines}

Stationary internal combustion diesel engines are sources of several air pollutants including nitrogen oxides, carbon monoxide, particulates, hydro-carbons, and sulfur dioxide. The $\mathrm{NO}_{\mathrm{x}}$ emissions from the engines are of the most concern because (1) $\mathrm{NO}_{X}$ is the primary pollutant emitted by stationary engines compared with total emissions for each pollutant; and (2) the EPA has assigned a high priority to development of $\mathrm{NO}_{\mathrm{x}}$ emission standards. 


\section{Gas Reciprocating Engine Systems}

Gas engine cogeneration systems, utilizing spark ignition Otto cycle reciprocating engines, operate in the same way as diesel systems. Electricity is produced by the engine-generator set, and steam and/or hot water is produced by a heat recovery unit utilizing the engine exhaust and heat from the jacket cooling system.

A major trend in the cogeneration market is toward small "packaged" systems, which usually have natural gas-fired reciprocation engines as their prime movers. Package systems offer full integration of all system components.

To give an example of their performance, a series of packaged systems, rated between 400 and $600 \mathrm{~kW}$, can produce $2,300 \mathrm{lb} / \mathrm{hr}$ of 15 psi steam or between 2 and 3 million Btu/hr of hot water at 180 to $230^{\circ} \mathrm{F}$. These units can use either natural gas or No. 2 fuel oil, and are provided with an exhaust gas fir-tube boiler for steam or hot water generation. Other packaged systems also include absorption chillers which use excess waste heat in the summer for space cooling.

\section{Heat Recovery Boiler}

The heat recovery boiler is used to transfer heat from the hot gases exhausted by gas turbines, diesels and other heat engines, or from stack gases, to produce steam. Several stack or engines may be connected to a common boiler.

The temperature at which the exhaust gases enter the recovery boiler is usually a few degrees less than the engine exhaust temperature, because some heat is lost through the walls of the duct connecting the engine to the boiler. Leakage losses through duct connections will also reduce the flow of gases to the boiler. Both the temperature drop and the flow losses will depend upon the particular placement of the boiler relative to the engine and the length, insulation, and integrity of the ducts connecting them. For estimating purposes, the temperature drop and flow losses may be taken to be $10^{\circ} \mathrm{F}$ and 2 percent, respectively. 


\section{Chapter 1 The Federal Process}

Throughout this chapter readers will be introduced to important federal agencies and important national acts that every cogenerator must know and learn about. In these days of global warming and concern over the environment, the environmental impacts of cogeneration is an important consideration. Therefore, this chapter begins by introducing the Environmental Protection Agency and significant national environmental acts and laws. Next for the cogeneration facility generating electricity on-site and is considering marketing excess energy. The reader is introduced to the Federal Regulatory Commission and the Public Utility Regulatory Policies. And last, the roles of Northwest regional institutions such as the Northwest Power Planning Council and Bonneville Power Administration are explained.

\section{Federal Environmental Guidelines}

\section{Environmental Protection Agency}

The Environmental Protection Agency (EPA) is a federal agency invested with authority over pollution control. It is responsible for the development of detailed, specific standards prescribing the limits of pollution for various contaminants and sources. It is entrusted-by Congress-to reduce pollution to levels "requisite to protect the public health."

\section{National Environmental Policy Act of 1969}

On January 1, 1970, the National Environmental Policy Act of 1969 (P.L. 91-190) became law. The Act declares that all practical means will be applied to conduct federal activities in a way that will promote the general welfare and harmony of the environment. Section 102 of the Act directs that to the fullest extent possible the policies, regulations, and public laws of the United States shall be interpreted and administered in accordance with the policies set forth in this Act, and all agencies of the federal government shall:

Include in every recommendation or report on proposals for legislation and other major federal activities significantly effecting the quality of the human environment, a detailed statement by the responsible official on:

- the environmental impact of the proposed action

- any adverse environmental effects which cannot be avoided should the proposed action be implemented

- alternatives to the proposed action

- the relationship between local sort-term use of man's environment and the maintenance and enhancement of long-term productivity

- any irreversible or irretrievable commitments of resources which would be involved if the proposed action should be implemented.

Primary environmental considerations in implementing cogeneration systems are regulations controlling air emissions and water effluents of specific pollutants caused by fuel combustion. 
The most limiting regulations for fuel combustion systems are those dealing with air pollution caused by siting and operational requirements. To a lesser extent water quality and solid waste regulations also impact combustion systems.

\section{Preparing Environmental Impact Statements}

When a proposed action is projected to have a significant impact on the quality of the human environment, an environmental impact statement (EIS) must be prepared. An EIS is intended to provide decision makers and the public with a complete and objective evaluation of significant environmental impacts, both beneficial and adverse, resulting from a proposed actions and all reasonable alternatives. An EIS is a major vehicle for fulfilling the substantive environmental goals set forth in the National Environmental Policy Act.

\section{Preparing a New EIS}

The process includes the following:

- scoping the EIS to focus the analysis on significant issues and reasonable alternatives

- publishing a notice of intent in the Federal Register to notify persons or agencies interested in, or affected by, a proposed federal action and to seek information and/or participation in scoping

- conducting the analysis and preparing the draft EIS

- $\quad$ issuing the draft EIS for public and other agency comments

- analyzing the comments and preparing the final EIS

- issuing the final EIS for comment

- reaching and recording the decision.

Once the draft EIS is completed and has gone through internal review, it is printed, filed with the EPA, and issued for public review and comment. A period of at least 60 days from the date the draft EIS is transmitted to EPA must be allowed for public review. A notice as to the availability of the draft EIS is normally published in the Federal Register and a press release is usually prepared for national and/or local media to announce the availability of the draft and to announce any public meeting or hearings.

Copies of the draft EIS are distributed to federal, state, and local agencies, individuals, and organizations on the mailing list and they are invited to be participants in public meetings.

Public meetings/hearings are usually held during the draft review period to receive comments on the draft. Once all meetings/hearings are held and public and agency comments received, the input is recorded and a final EIS is prepared, taking into account all relevant comments that are substantive and that relate to inadequacies or inaccuracies in the analysis or methodologies used, identify new impacts or recommend reasonable new aiternatives or mitigation measures, or involve substantive disagreements on interpretation of significance.

If substantive comments are received, the official in charge must determine whether the new impacts, new alternatives, or new mitigation measures should be analyzed in either the final EIS, a supplement to the draft EIS, or a completely revised and recirculated draft EIS. 
Once it is determined that a final EIS should be prepared, all substantive comments, changes, corrections, and revisions are incorporated into a preliminary final EIS. The document is then circulated for internal concurrence and must be approved by the manager responsible for authorizing the action covered by the EIS.

Following approval, the EIS is printed, filed with the EPA, and distributed to the public. A notice of availability must be published in the Federal Register and a press release is issued to national and/or local media. Copies are generally madr available to all substantive comments and others who have a strong interest in the proposal( $:$ ).

The Record of Decision (ROD) is not issued until a 30-day no-action period has lapsed following the publication of the EPA notice on the final EIS in the Federal Register and other programspecific requirements, if any, have been met.

Comments on the final EIS, if any, must be reviewed to determine if they identify significant issues not previously addressed or introduce new significant information. If substantial comments are received, the manager responsible for preparing the EIS must determine whether a supplemental draft EIS or supplemental final EIS is warranted. If not, the commentor(s) are advised, if possible and appropriate, of the availability date for the ROD.

The public must be advised of the availability of the ROD and a notice of availability is published in the Federal Register as well as in national and/or local press. Copies of the decision are made available to substantive commentors and to others known to have a strong interest in the proposal(s).

Following the 30-day availability period, a decision may be made. Decisions on an EIS are recorded in a public ROD. No action concerning a proposal may be taken until the ROD has been issued, except under conditions specified in 40 C.F.R. 1506.1.

\section{Incorporating by Reference (40 C.F.R. 1502.4)}

Incorporating previous analysis by reference in an EIS is a technique used to avoid redundancies in analysis and to reduce the bulk of NEPA documents. Materials or analyses incorporated by reference are not limited to NEPA documents. Special technical or professional studies and analysis prepared by other federal agencies, state, local, or tribal governments, or private interests may be incorporated by reference. If a document is incorporated by reference is at the heart of the EIS, it should be circulated for comment as part of the draft.

\section{Supplementing (40 C.F.R. 1502.9(c))}

Supplements to an existing draft or final EIS are prepared when additional environmental analysis is needed. The relationship between the supplement and the existing EIS is lateral, i.e., the proposed action and alternatives are analyzed to the same level of specificity and detail. A supplemental EIS is often used to address alternative not previously analyzed and may lead to new decisions. 
A supplement is generally prepared when:

- there are substantial changes in the proposed action that are relevant to environmental concerns

- there are significant new circumstances or facts relevant to environmental concerns and bearing on the proposed action or its impacts which were not addressed in the existing analyses

- using another agency's environmental document and additional analysis is needed.

An example of when supplementing an EIS may be appropriate is when a substantial change is proposed for a planned transmission line, pipe line, or power plant which was analyzed in a previous EIS.

\section{Using Another Agency's EIS (40 C.F.R. 1506.3)}

The purpose of using another agency's environmental document for NEPA compliance is to reduce paperwork, eliminate duplication, and/or make the process more efficient. Use of another agency's EIS is accomplished by either formally cooperating in its development or adopting all or parts of the EIS.

\section{Tiering (40 C.F.R. 1508.28)}

Tiering is used to prepare new, more specific, or more narrow environmental documents without duplicating relevant parts of previously prepared, more general, or broader documents. The more specific or more narrow environmental documents incorporate by reference the general discussion and analysis from the broader document and concentrate on the issues and impacts of the project which are not specifically covered in the broader document.

Tiering is appropriate when:

- The analysis for the proposed action will be a more site- or project-specific refinement or extension of the existing analysis.

- The decisions associated with the existing environmental document will not be changed as a result of the tiering.

Existing environmental analysis should be used in analyzing impacts associated with a proposed action to the extent possible and appropriate. This approach builds on work that has already been done, avoids redundancy, and provides a coherent and logical record of the analytical and decision making process (NEPA Handbook, 14-1790-1).

Several questions must be ac'dressed before an existing environmental analysis may be used:

- Have any relevant environmental analysis related to the proposed action been prepared?

- Who prepared and cooperated in the preparation of the analysis?

- Do any of the existing analysis fully analyze the proposed action and altematives?

In determining whether an existing environmental impact statement covers a proposer action currently under consideration, the criteria are as follows: 
- The new proposed action is a feature of or essentially the same as the alternative selected in the document being reviewed.

- A reasonable range of altematives to the new proposed action was analyzed in the document being reviewed, i.e., there are no unresolved conflicts involving alternative resource uses for the new proposed action.

- The circumstances or information upon which the document being reviewed is based are still valid and germane to the new proposed action, i.e., there is no significant change in circumstances and no significant new information.

- The methodology or analytical approach used in the document being reviewed is appropriate for the new proposed action.

- The direct and indirect impacts of the new proposed action are not significantly different than, or are essentially the same as those identified in the document being reviewed.

\section{Air Quality}

Emission and performance standards prescribe limits on discharges from individual pollution sources. Air-quality standards representing safe or acceptable concentrations provide a partial basis for the design of emission standards to achieve the ultimate goal of protecting beneficial uses of the air from excessive impairment.

\section{Clean Air Act of 1970 (42 USC 7401 et.seq.), Clean Air Amendments of 1977 and 1990}

The Clean Air Act of 1970 (42 USC 7401 et.seq.) and Amendments of 1977 and 1990 (P.L. 101 $1531)$ alter the regulatory program affecting cogeneration and other energy technologies. Efforts have been made to simplify and streamline the permitting process and to reduce some of the more restrictive requirements.

Early in 1971, primary and secondary air-quality standards for six pollutants were developed: particulate mater, sulfur dioxide, carbon monoxide, hydrocarbons, nitrogen oxides, and photo chemical oxidants. Lead was added in 1979. Congress in 1970 provided for the issuance of federal air-quality standards. The Clean Air Act authorizes the Administrator of the Environmental Protection Agency to adopt both "primary" and "secondary" standards for any pollutant that comes from "numerous or divers ... sources" if it "may reasonably be anticipated to endanger public health or welfare." Primary standards are defined as those which, "allowing an adequate margin of safety, requisite to protect the public health"; secondary standards are those "requisite to protect the public welfare from any known or anticipated adverse effects."

Each state is required to develop an air quality implementation plan subject to the approval of the EPA approval. If EPA determines that a state plan is "not ... in accordance with the requirements" EPA is directed to adopt one of his own for the state in question. 
New cogeneration facilities will be affected by regulations for 1) Prevention of Significant Deterioration (PSD), 2) Non-attainment areas, and 3) New Source Performance Standards (NSPS), in some cases, modifications to existing industrial plants where cogeneration systems are planned will also be affected by these regulations.

\section{Prevention of Significant Deterioration (PSD)}

The basic objective of the Prevention of Significant Deterioration (PSD) program is to prevent substantial degradation of air quality in areas that are in compliance with National Ambient Air Quality Standards (NAAQS) while maintaining a margin for future industrial growth (ambient air refers to the air out-of-doors, all matter making its way into the outdoor air, is a "pollutant"; whether or not it is harmful). Each proposed new or modified air contaminant source must undergo a new source review. As part of this review, PSD applicability is determined. If PSD review is required, a PSD application must be submitted and a permit obtained before beginning project construction.

Cogeneration systems are subject to permit requirements imposed by PSD regulations in areas that are attained NAAQS. Areas classified as non-attainment have different permit requirements as described later.

Under PSD regulations, most industrial firms building a new plant or installing a cogeneration system at an existing plant must submit a PSD permit application if the source will emit an excess of $100^{*}$ tons/year (TPY) of a criteria pollutant** and if the cogeneration plant (considered in an existing plant of part of a new plant); as a modified source, emits pollutants greater than levels considered significant. In the latter case, the PSD permit application must consider only those pollutants considered significant. In the permit application, the source owner or operator must provide an air quality modeling analysis to assess impacts on NAAQS and allowable increments. In some cases, baseline air quality data must be provided by means of measurements taken over a period of one year, if no data exists that meet EPA requirements. The need for baseline data usually occurs for sources located in rural areas, while in urban areas there is usually adequate historical dara. The permit application is submitted to an EPA regional office which will review the application and issue the permit. A list of ten regional offices is presented in Appendix $1 \mathrm{~A}$.

An additional major requirement for PSD is the application of Best Available Control Technology (BACT) for all pollutants subject to the PSD regulations. The BACT may take the form of a specific control technology in industrial process, or an emission limitation that the source may meet by any technology in industrial processes, or an emission limitation that the source - Plants in one of 28 categories defined by EPA. If not in one of these categories the limitation increases to 250
tons/year.

* Criteria pollutant refers to pollutants for which ambient air quality standards have been established on the basis of health and welfare effects. 
may meet by any technology capable of achieving these limitations. Generally, BACT may be negotiated between the source and EPA, based on source-specific considerations which consider the energy, environmental, and economic aspects of control options. For cogeneration applications using conventional steam turbine systems, BACT will require electrostatic precipitators or fabric filters for particulates, and flue gas desulfurization or low-sulfur fuels for sulfur dioxide. For gas turbines, however, this requirement can be met by using low-sulfur and low-ash fuel.

Additional miscellaneous impact analyses are required for the permit applications. The source owner must analyze the impairment of visibility, soils, and vegetation that would occur as a result of construction or modification of source. This analysis must include the effect of general commercial, residential, industrial, and other growth associated with the construction or modification. Also, an analysis is required of the air quality impact of the area as a result of general commercial, residential, and industrial growth associated with the project. No standard permit forms exist for PSD, although, the regional office can provide guidance on preparing the application.

More specific information on PSD requirements can be found in the Code of Federal Regulations (CFR) 40 CFR 52.21. However, this regulation is quite complex, so it is best to contact the appropriate air authority in your state to determine if your proposal will require PSD review.

\section{Non-attainment Areas}

Those areas that have not achieved NAAQS for one or more pollutants have been classified as "non-attainment," and sources wishing to locate in these areas are not subject to PSD requirements. Major emission sources in these areas must, however:

- arrange for emission reductions from existing sources in the region that more than offset the total emissions of the new source or modification

- meet the Lowest Achievable Emission Rate (LAER) for the non-attainment pollutant. The LEAR is the lowest emission level achieved in practice or required by any State Implementation Plan for attaining air quality standards.

All other sources under the same ownership as the source or modification must be in compliance or under compliance schedules for all pertinent emissions. The attainment status of any area can be obtained from the state air pollution control agency or the EPA regional office.

\section{New Source Performance Standards (NSPS)}

The New Source Performance Standards (NSPS) regulates emissions of specific pollutants for sources starting operation after the promulgation date of the standards. No standards exist specifically for cogeneration systems; however, standards do exist for fossil fuel steam generators and electric utility steam generators greater than 250 million Btu/hour heat input and for stationary gas turbines of 10 million Btu/hour heat input and greater. Cogeneration facilities with greater than 250 million Btu heat input and selling more than $25 \mathrm{MW}$ of electricity or more than 
one-third of their potential electrical output capacity would be regulated by the NSPS for electric utility steam generators. Facilities selling less electricity would be regulated under the less stringent regulations for fossil fuel steam generators of greater than 250 million Btu/hour heat input.

The EPA also requires NSPS's for several other source categories which can be used in cogeneration applications including industrial boilers, non-fossil fuel industrial boilers. These standards apply to particulate emissions from boilers firing wood, municipal solid waste, refuse-derived fuels. For coal and wood mixtures, $\mathrm{SO}_{2}$ standards also apply.

The NSPS for stationary internal combustion engines has been formulated; it is applicable to all diesel and dual-fuel engines that are greater than 560 cubic inch displacement per cylinder. The standards are applicable only to $\mathrm{NO}_{\mathrm{x}}$ emissions and limit emissions to 600 parts per million, corrected to 15 percent oxygen on a dry basis.

\section{Air Emissions Control}

This section presents a description of the environmental pollutants produced by the three main combustion systems used in cogeneration applications. The combustion systems include steam turbines, gas turbines, and diesel engines. Air pollutants are major environmental residuals as a result of cogeneration, and will have the greatest impact on siting new or modifying existing facilities.

\section{Water Quality}

\section{Federal Water Pollution Control Act (WPCA)}

Under the Federal Water Pollution Control Act an industry or "point source discharging pollutants into navigable water must have a National Pollution Discharge Elimination permit. A "point source" is a discernible, confined, discrete source.

The Act authorizes states to adopt water quality standards. State standards consider the value of water for public drinking supplies, propagation of fish and wildlife, and recreation, among other uses. Each standard considers the respective uses and value of the water and includes criteria based on those uses.

A "point source" wishing to discharge anything into navigable waters must comply with federal and state water quality standards. Applicants must obtain a certificate that all discharges will comply with the standards.

A certificate is required for any discharge. It applies even when a water user does not add anything to discharged water. For instance, a dam or diversion adds nothing to the water, but it may diminish flow needed to dilute downstream wastes. It may also change naturally-occurring temperatures and the dissolved oxygen level. If a state rule on one of these water quality parameters is violated, a certificate of compliance will be denied. 
The Act requires that discharges comply "with any other appropriate requirement of state law." It requires federal permits and licenses be granted subject to any appropriate requirement of state law.

\section{New Source Performance Standards}

New Source Performance Standards for water quality have been established for several industrial source categories, including steam electric power generating. These standards apply to facilities generating electricity for distribution and sale, with the exception of facilities with less than 25 MW rated net generation capacity or any units that are part of an electric utilities system with a total net generating capacity less than $150 \mathrm{MW}$. No water quality standards exist or are proposed for other combustion systems that can be used in cogeneration.

\section{National Pollutant Discharge Elimination System Permit (402 Permit)}

A National Pollutant Discharge Elimination Systems (NPDES) permit is required where a wasie water source is discharged to "waters of the United States." If a cogeneration project affects the quality of water in any way by adding sediments, decreasing oxygen content, or increasing temperature, this may be construed as discharging a pollutant and requires a NPDES permit. For more information, contact the EPA office listed in Appendix 1A.

A NPDES permit is usually required in all states for industrial wastewater. The permit application must indicate the type of facility to be operated, quantities of wastewater, pollution control system used, and composition of the waste waters. States are responsible for regulating soiid wastes for industrial sources that may impact surface and ground waters. A coal-fired boiler will generate fly ash and bottom ash that must be disposed of in approved landfills. Boiler wastes are usually exempt from hazardous waste regulations. However, the state may require an analysis of the wastes to assess whether surface or ground waters may be contaminated, especially by heavy metals in the bottom ash.

\section{Table 1}

NPDES Permit Application Forms

Permit Category

Any industrial, commercial, manufacturing, or mining activity
a. In quantities exceeding 50,000 gallons on any day of the year
b. In quantities of 50,000 gallons or less but which discharges a toxic pollutant

Application Form

Standard Form C

[EPA Form 7550-23A (7-73)] 
The application requires information on waste source flow and expected characteristics, disposal method, water supply, waste water disposal, water supply volumes, water utilization, planned improvements, storm water treatment, plant operation, materials and chemicals used, and production.

\section{Solid and Hazardous Waste}

Resource Conservation and Recovery Act (RCRA)

Solid and hazardous wasto management is regulated under the Resource Conservation and Recovery Act (RCRA) which addresses pollution of the terrestrial environment by solid and hazardous wastes, including those generated by air-and water-pollution control devices. These regulations are not expected to have much impact on combustion systems used in cogeneration applications as most of the wastes produced by these systerns are exempt from the regulations. These wastes include fly ash, buttum ash, slag, and flue gas emission control waste generated primarily from the combustion of coal or other fossil fuels. Management of these wastes will be controlled by state regulations. Solid or liquid waste that may meet the criteria of hazardous wastes are those containirig corrosion i. hibitors used to prevent boiler tube fouling in steam turbine systems.

\section{Other Federal Environmental Regulations}

Endangered Species Act of 1973

In 1973, the United States Congress passed the Endangered Species Act, P.L. 93-205. This act protects fish, wildlife and plants endangered or threatened with extinction. The Act also protects the ecosystems on which they depend. Federal agencies are to work with state and local agencies to protect endangered species.

Various species of fish, wildlife, and plants in the United States have been rendered extinct or in danger of extinction as a conseqierice of economic growth and development. These species of fish, wildlife, and plants have been found to have esthetic, ecological, educational, historical, recreational, and scientific value. Therefore, the United States encourages the states and other interested parties to develop and maintain conservation programs which meet national and international standards to preserve the nation's heritage in fish, wildlife, and plants. The ecosystem upon which endangered and threatened species depend must also be preserved.

It is declared to be the policy of Congress that all federal departments and agencies shall seek to conserve endangered and threatened species and shall utilize their authorities in furtherance of the purposes of the Act. Federal agencies shall cooperate with state and local agencies to resolve water resource issues in concert with conservation of endangered species.

Each federal agency shall in consultation with and assistance of the Secretary, ensure that any action authorized, funded, or carried out by such agency (action) is not likely to jeopardize the continued existence of any endangered or threatened species or result in the destruction or ad- 
verse modification of the habitat of such species...unless the agency has been granted an exemption for such action. In fulfilling the requirements of this paragraph each agency must use the best scientific and commercial data available.

A federal agency shail consult with the Secretary on any proposed agency action if there is reason to believe that an endangered or threatened species may be present in the area affected by a project and the implementation of such action will likely affect such species.

A biological assessment to identify any endangered species or threatened species for the purpose of identifying any endangered or threatened species which is likely to be affected by such action. Such assessment must be completed within $\mathbf{1 8 0}$ days if a permit or license application is involved (unless the agency provides the applicant with a written statement setting forth the estimated length of the proposed extension and the reason therefore). The assessment must be completed before any permit or license is granted and before any contract for construction is entered into or before any construction is begun. Such assessment may be undertaken as part of a federal agency's compliance with the requirements of section 102 of the National Environmental Policy Act of 1969 (42 U.S.C. 4332).

Any person who may wish to apply for an exemption under provisions of the Act for that action may conduct a biological assessment to identify any endangered species or threatened species which is likely to be affected by such action. Any such biological assessment must, however, be conducted in cooperation with the Secretary and under the supervision of the appropriate federal agency.

\section{Power: Sales}

The culmination of any successful resource development project is the sale of thermal energy or electrical output. A number of federal and regional agencies have played an important role in the establishment of the framework within which power sales are negotiated and entered into, including price structure and utility interconnection. At the federal level the Federal Energy Regule ory Commission (FERC) plays the dominant role while regionally the Northwest Power Planning Council (NPPC) and the Bonneville Power Administration (BPA) are the principal players.

Much of the legal framework was established in 1978 with the passage of the Public Utilities Regulatory Policies Act, P.L. 95-617, which provided developers of renewable energy projects with an opportunity to market electricity directly to utilities without fear of public utility regulation. Each state has also enacted legislation or administratively addressed the needs of non-utility developers of generation projects. 


\section{Federal Energy Regulatory Commission}

Established October 1, 1977, by the U.S. Department of Energy Organization Act, the Federal Regulatory Commission (FERC) is an independent regulatory agency within the Department of Energy (USDOE). Its primary goal is to assure the nation's consumers adequate energy supplies at just an reasonable rates, while allowing energy producers sufficient rates of return to provide incentives for increased productivity and efficiency. Its primary function is to regulate, directly or indirectly, the production, transmission, and sale of electric power, natural gas, and cil in interstate commerce.

Since electric grids and gas pipelines often extend over state lines, FERC has primary jurisdiction over a state's utilities. Non-regulated utilities, i.e., those not state-regulated, and federal power marketing agencies are regulated by FERC. Also, FERC regulates all wholesale transactions between utilities, federal power marketers and qualifying facilities (QFs). Trans-actions between direct service industries and federal power marketers are FERC-regulated. In the case of PURPA, the states are required to implement FERC rules for state-regulated utilities (Bain, 1989).

FERC is the most important federal agency relating to Qualifying Facilities (QFs) and the Public Utilities Regulatory Act (PURPA). Section 201 of the PURPA of 1978 designated certain small power production and cogeneration facilities as qualifying facilities eligible for various benefits. The FERC promulgated rules (Code of Federal Regulations, Title 18, Part 292) under which the qualifying status of a facility may be determined in advance of construction or operation. Although a facility is automatically a qualifying facility if it meets the requirements of the rules, the owner or operator seeking qualifying benefits is required to file an information report with FERC, known as a Notice of Qualifying Status. Alternatively, application may be made to the Commission for certification as a qualifying facility.

Aside from issuing PURPA rules (see PURPA overview), FERC has a major role in several areas that affect QFs. Of primary importance to developers is the QF certification process. Although FERC has rules for QF self-certification, many QFs seek FERC certification. Persons financing QFs often want to remove any uncertainty about qualifying status. However, seeking FERC certification opens a public comment period during which project opponents have standing to submit objections. FERC certification also is expensive. Recently, the certification process has been used by some developers to get qualifying status for their facility including miles of dedicated transmission lines. Such lines can extend the rights and obligations granted QFs by PURPA into other utilities' service territories. FERC is also playing a major role in expanding the market place for non-utility wholesale generation and addressing problems associated with transmission access and wheeling.

The following sections discuss in more detail the cogeneration provisions of PURPA, the National Gas Policy Act (NGPA), and the pertinent implementing rules. Prospective cogenerators should refer to the Federal Register and consult with the appropriate federal agency to obtain the latest information on implementing rules. 


\section{Public Utility Regulatory Policies Act of 1978 (PURPA)}

\section{Background}

Congress enacted the Public Utilities Regulatory Policies Act (PURPA), P.L. 95-617, on November 9, 1978, as one of five component bills to the National Energy Act of 1978. PURPA was designed to lessen the country's dependence on foreign oil by requiring state utility commissions to consider rate structures that conserve energy and by encouraging the development of energy efficiency, cogeneration, biomass-fired power plants, and renewable generating re-

sources. Renewable resources include solar, wind, hydropower, and geothermal generating facilities.

PURPA amended the Federal Power Act to reduce or eliminate obstacles to the development of cogeneration and small power projects. In effect, PURPA requires utilities to interconnect with qualifying cogenerators and small power producers (QFs) located in their service territories, to purchase power at a price based on the utility's full avoided cost for energy and capacity, and to provide non-discriminatory rates for back-up services. PURPA also exempts small power producers from portions of the Federal Power Act, 16 USC 791a-828c (1981), the Public Utility Holding Company Act of 1935, 15 USC 79b(a)(3), and certain state utility regulations. PURPA does not, however, require a utility to interconnect with and purchase power from independent producers located outside of its service territory.

Of particular importance to independent power producers are the provisions of PURPA dealing with small power production. Specifically, under Title II Sections 201 and 210, the Federal Energy Regulatory Commission (FERC) amended its regulations to deal with such critical issues as size, ownership, and efficiency criteria for qualifying small power production and cogenera-tion facilities; electric utility obligations; rates for purchase and sales; interconnection cost reimbursements; and state implementation requirements regarding PURPA. (These changes are located in Title 18 of the Code of Federal Regulations (CFR), Chapter I, Part 292.)

\section{PURPA Overview}

PURPA contains a number of significant provisions designed to encourage industrial cogeneration by preventing electric utility discrimination and reducing utility-related state and federal regulations.

Congress enacted sections 201 and 210 of PURPA as a part of the National Energy Act of 1978. These provisions authorized the Federal Energy Regulatory Commission (FERC) to prescribe rules as the Commission determines necessary to encourage cogeneration.

Section 210 of PURPA authorized FERC to prescribe rules requiring electric utilities to purchase electric energy from cogeneration facilities which obtain qualifying status under Section 201 of PURPA. For such purchases, FERC was authorized to require electric utilities to pay rates that are just and reasonable to the rate payers of the utility, are in the public interest, and that do not discriminate against cogenerators. Section 210 also required electric utilities to provide retail 
electric service to qualifying cogeneration facilities at just, reasonable, and non-discriminatory rates. Finally, Section 210 authorized FERC to exempt all qualifying cogeneration facilities from state regulation regarding utility rates and financial organization, from federal regulation under the Federal Power Act, and from the Public Utility Holding Company Act.

Section 201 of PURPA authorized FERC to prescribe rules establishing requirements for qualifying cogeneration facilities and develop procedures by which the qualified facilities can obtain the benefits set for under Section 210.

\section{Applicability of FERC Rules}

The rules promulgated by FERC apply to all electric utilities, defined in Section 3(4) of PURPA as any person, state agency, or federal agency which sells electric energy. Within this definition are investor-owned systems, cooperatively owned systems, and federal power-marketing agencies.

\section{Exchanges of Power Between Utilities and Cogenerators}

In recognition that it could not prescribe a perfect pricing formula appropriate for each utility and qualifying cogenerator, FERC issued a set of pricing principles to be used by the State Regulatory Commissions (SRC) and non-regulated utilities in developing methodologies of specifying rates. The operative term used in these pricing principles is "avoided cost." Under the "avoided cost" principle, rates for power produced by the cogeneration facility are based on the costs avoided by the utility in not having to generate the power itself or purchase it from another source. This obviates the need for the cogenerator to keep detailed cost-of-service records.

In those instances where a utility can cut back on its need to construct new power plants or to buy, lease, or rent capacity from another utility, the avoided cost can also include the capital costs of the otherwise required unit or the demand charge is included in the utility's firm power purchase contract.

FERC specifies that all interconnection requirements be reasonable. As for what is "reasonable," the regulations leave it up to SRCs to decide. These commissions must also make sure that the costs of interconnection are attributable to the cogeneration system. FERC regulations stipulate that the utility cannot charge the qualifying facility any more for interconnection than the actual net expense of connecting the qualifying facility, less charges the utility would have had to incur to connect its own power plants to its system to provide the same amount of power. Finally, FERC regulations state that a qualifying facility cannot be assessed twice for the same connection. If a qualifying facility that had already been connected to an electric utility for the purpose of buying electricity decides to sell power to the utility, the qualifying facility can only be charged for additional expenses. 
FERC's pricing rules state that if a qualifying cogenerator consents, the purchasing utility may transmit power to a second utility. If this occurs, the second utility is subject to the same purchase requirements as the "wheeling" utility, except that the second utility is only obligated to pay of the power it actually receives.

For fower purchases from a cogeneration facility whose construction commenced on or after the date of enactment of PURPA (November 9, 1978), utilities must pay the full avoided cost. For existing facilities, utilities may pay a lower rate so long as the rate is sufficient to encourage cogeneration.

The FERC rules also permit a new cogenerator to require an electric utility to purchase, at full avoided cost, all of the power produced by the new cogeneration capacity, while permitting the cogenerator to purchase all of the electric power it uses at non-discriminatory retail rates. The effect of this provision is to separate the activities of the facility as a genfrator and as a load, thereby enhancing the likelihood that new cogeneration capacity will be developed.

\section{Criteria for Qualification as Cogeneration Facility}

Two basic types of QFs exist: small power producers and cogenerators. Small power producers generate electricity from fuels other than oil and natural gas, i.e., biomass. A small power producer (SPP) is automatically a QF under PURPA if it meets specified size, fuel use, and ownership criteria. Oil or gas-fired cogeneration projects must meet additional operating and efficiency standards to be considered QFs. Small Power Production Facilities are defined as electric generating facilities 75 percent or more of who's energy input comes from a renewable resource, geothermal, or waste. Typical examples are wind, water (hydropower), solar, the burning of garbage, waste, coal or byproduct materials.

Section 201 of PURPA contains the criteria for designation as a qualifying cogeneration facility. It defines a cogeneration facility as a facility which produces electric energy and steam or forms of useful energy (such as heat) which are used for industrial, commercial, heating, or cooling purposes. The definition of a cogeneration facility established by FERC requires that electric energy and forms of useful thermal energy be produced through the sequential use of energy. Within this definition, it is important to note that electric energy must be produced to qualify as a cogeneration facility. Sequential use of energy is the key provision of this definition. Only those process that use heat rejected from one process for another process can be considered cogeneration facilities.

Eligible cogeneration includes both topping-cycle and bottoming-cycle cogeneration facilities. In 18 CFR 292.203, new diesel cogeneration systems were excluded as qualifying facilities pending further FERC action. However, on June 1, 1981 (Order 70-E), the commission approved an amendment to the PURPA rule allowing diesel and dual-fuel systems to be qualifying facilities and thus be legible for PURPA benefits. 
A cogeneration facility is a qualifying facility if it can meet the operating and efficiency standards and the ownership criteria prescribed by FERC in 18 CFR 292, Subpart B.

For multi-fuel fired facilities, at least 75 percent of the total energy input must be from biomass, wastes, renewable resources, including geothermal resources, or any combination thereof. During any calendar year, supplemental oil, natural gas, or coal use cannot exceed 25 percent of the total facility energy input.

\section{Operating Efficiency Standards}

To obtain qualifying status, the cogeneration facility may have to meet operating and efficiency standards established by FERC. All topping-cycle cogenerators must meet FERC's operating standard. If oil or natural gas is used by new topping-cycle cogenerators, the efficiency standards pertain as w'ell. No operating standard are prescribed for bottoming-cycle cogenerators. However, if oil or natural gas is used for supplementary firing, an efficiency standard is applied.

- Topping-Cycle Facilities

\section{Operating Standard}

The useful thermal energy output of the facility must, during any calendar year, be no less than 5 percent of the total energy output. This standard applies to all topping-cycle cogenerators regardless of the fuel used or date of installation.

\section{Efficiency Standard}

If any of the energy output is natural gas or oil and installation of the cogeneration facility began on or after March 13,1980, the useful power output of the facility plus onehalf the useful thermal output during any calendar year period must:

- be no less than 42.5 percent of the total energy input of natural gas or oil, or

- be no less than $\mathbf{4 5}$ percent of the total energy input of natural gas and oil if the useful thermal energy output is less than 15 percent of the total energy output of the facility.

- Bottoming-Cycle Facilities

Operating Standard

None prescribed for bottoming cycle facilities.

\section{Efficiency Standard}

For any bottoming-cycle cogeneration facility for which any of the energy input is supplementary firing is natural gas or oil, and the installation of which began on or after March 13, 1980, the useful power output must, during any calendar year period, be no less than 45 percent of the energy input of the natural gas and oil used for supplementary firing.

- Plant efficiency: plant efficiency is defined in the PURPA regulations as useful power production plus one-half of the useful thermal energy with the total divided by the total energy input from natural gas and oil. 
- Efficiency standard-other fuels: there is no thermal efficiency standard for fuels other than natural gas and oil.

- Calculation: all quantities are calculated on an annual basis. Useful electric power production does not include auxiliary power or parsitic loads to run the cogeneration facility. Steam energy is measured as the enthalpy difference between steam sent out and the condensate return.

- Size, unique rules apply: under 30 megawatts the standard PURPA rules apply and the facility is exernpt from state and federal regulation. From 30 to 80 megawatts the QF (unless owned by a unit of government) must obtain waivers from FERC of regulation under the Federal Power Act for any sales to the area electric utility. Such waivers are routinely granted. The facility may not exceed 80 megawatts.

- Geographic test: all power production equipment owned by the same owner within one mile is considered to be one facility (for hydropower plants the water must also come from a common source, i.e., lake or river).

- Fossil use: fossil fuel usages at the facility are limited to 25 percent of annual fuel use.

\section{Ownership Criteria}

To qualify for the regulatory exemptions and the electric power sale and purchase benefits under PURPA, a cogeneration facility must be owned by a person not primarily engaged in the generation or sale of electric power (other than electric power solely from cogeneration facilities). Electric utilities may participate in joint ventures that own qualifying facilities. However, electric utilities may together own no more than 50 percent of the equity of a qualifying facility (18 CFR 292.206). All qualifying facilities (topping cycle cogeneration, bottoming cycle cogeneration and small power production) must be less than 50 percent owned by electric utilities, their subsidiaries or affiliates.

A cogeneration or small power production facility is considered to be owned by persons "primarily engaged in the generation or sale of electric power," if more than 50 percent of the equity interest in the facility is held by an electric utility or utilities, or by an electric utility holding company, or companies, or any combination thereof. If a wholly or partially owned subsidiary of an electric utility or public utility holding company has an ownership interest of a facility, the subsidiary's ownership interest shall be considered as ownership by an electric utility or public utility holding company."

\section{Regulatory Exemptions}

One of the three objectives of PURPA is to exempt QFs from regulation as electric utilities. The FERC regulations do so by providing certain exemptions from the Federal Power Act (FPA), the 
Public Utility Holding Company Act of 1935, and state laws and regulations (see 18 CFR 292.601 and .602 page). These exemptions apply only to financial, organizational and rate issues. They do not affect environmental, zoning, planning, construction, licensing, or any other laws or regulations related to generating plants.

QFs are exempt from the FPA as follows:

- In general, small power producers (SPPs) are QFs if they have a design capacity of up to $80 \mathrm{MW}$. This restriction was removed from cogeneration power production under provision of P.L. 101-575. However, only SPPs of $30 \mathrm{MW}$ or less are exempt from any part of the FPA. All qualifying cogeneration facilities are exempt.

- SPPs of under $30 \mathrm{MW}$ are exempt from the traditional rate regulation and the regulation of securities of public utilities (sections 119, 120, 203, 204, 205, 206, 208, 301, 302, and 304 of the FPA).

But QFs are not exempt from certain provisions of the FPA. Thus QFs:

- $\quad$ are not exempt from most of Part I, which deals with license and permit requirements

- are not exempt from Section 202(c) under which QFs may have to provide energy if the Economic Regulatory Administration determines there is an emergency

- are not exempt from sections 210,211 and 212 , which provide for interconnection orders by FERC and allow a utility, federal power marketing agency or cogeneration $Q F$ to seek a wheeling order against a utility in a formal FERC proceeding

- are not exempt from Section 305(c), which imposes reporting requirements on interlocking directorates

- are not exempt from Part III, which has enforcement provisions, when the enforcement provisions apply to those sections from which the QFs are not exempt (listed above).

Certain QFs are exempt from all provisions of the Public Utility Holding Company Act of 1935 (PUHCA). These QFs include all biomass and cogeneration (CG) facilities (up to $80 \mathrm{MW}$ ). The $80 \mathrm{MW}$ limitation on cogeneration power production was eliminated in 1990 under provision of P.L. 101-575. However, other SPPs are exempt only if their design capacity is $30 \mathrm{MW}$ or less.

Such review and enforcement is not confined to whether or not the state commission or nonregulated utility properly put into effect regulations implementing PURPA 210. It also can include the case-by-case application of regulations.

Enforcement Procedures Summary

\begin{tabular}{|c|c|c|}
\hline $\begin{array}{l}\text { Order of } \\
\text { Redress }\end{array}$ & $\begin{array}{c}\text { For Actions } \\
\text { by Regulated } \\
\text { Utilities }\end{array}$ & $\begin{array}{c}\text { For Actions } \\
\text { by Non-regulated } \\
\text { Utilities }\end{array}$ \\
\hline $\begin{array}{l}\text { First } \\
\text { Second } \\
\text { Third }\end{array}$ & $\begin{array}{l}\text { State commission } \\
\text { State court or FERC } \\
\text { Federal Court }\end{array}$ & $\begin{array}{l}\text { FERC } \\
\text { Federal Court }\end{array}$ \\
\hline
\end{tabular}


The QFs described immediately above also are exempt from state laws and regulations regarding electric utility rates, finances, and organization. However, they are not exempt from the state laws and regulations intended to implement Subpart C of PURPA 210, which governs sales and purchases between $\mathrm{QFs}$ and utilities. State commissions and non-regulated utilities may apply to the FERC for a waiver from this broad exemption.

\section{PURPA Enforcement}

The FERC regulations implementing PURPA set certain procedures for enforcement and redress of grievances. Persons may go to state court or, under certain circumstances, to the FERC to require a state commission or non-regulated utility to implement the PURPA regulations, or to require enforcement of the implementation by the commission or non-regulated utility. Persons seeking review of any determination made by a federal power marketing agency may go to the appropriate federal court.

A state commission or non-regulated utility may require utility cost data that is different from what the PURPA regulations require. If a QF cannot derive the utility's avoided cost from this alternative data, the QF may go to court.

\begin{tabular}{|c|c|c|}
\hline \multicolumn{3}{|c|}{$\begin{array}{l}\text { Summary of Exemptions } \\
\text { from Regulations }\end{array}$} \\
\hline Law & $\begin{array}{l}\text { Who is } \\
\text { Exempt }\end{array}$ & $\begin{array}{l}\text { From Which } \\
\text { Section }\end{array}$ \\
\hline $\begin{array}{l}\text { Federal Power } \\
\text { Act (FPA) }\end{array}$ & $\begin{array}{l}\text { SPPs } 30 \mathrm{MW} \text { or less; } \\
\text { all CGs }\end{array}$ & $\begin{array}{l}119,120,203,204,205, \\
206,208,301,302,304 \\
\text { (regarding rate regulation and } \\
\text { regulation of securities of public } \\
\text { utilities) }\end{array}$ \\
\hline $\begin{array}{l}\text { Public Utility } \\
\text { Holding Company } \\
\text { Act (PUHCA) }\end{array}$ & $\begin{array}{l}\text { SPPs } 30 \mathrm{MW} \text { or less, } \\
\text { except biomass up } \\
\text { to } 80 \mathrm{MW} \text {; all CGs }\end{array}$ & All \\
\hline $\begin{array}{l}\text { State rules } \\
\text { and regulations }\end{array}$ & Same as PUHCA & $\begin{array}{l}\text { All goveming finance, organiza- } \\
\text { tion, and rate issues, except those } \\
\text { implementing Subpart C of the } \\
\text { PURPA } 210 \text { rules. }\end{array}$ \\
\hline
\end{tabular}


Small utilities need only provide system cost data on request of a QF. If such a utility fails to provide this information, the QF may apply to the state commission (if the utility is regulated) or to the FERC (for any kind of utility) for an order that it be supplied. However, the commission or the FERC should take into account the burden imposed on small utilities.

If a larger utility (greater than 500 million $\mathrm{kWh} /$ year in sales) does not provide the required avoided cost data, the FERC may prescribe the penalties in PURPA Section 133.

The FERC may revoke the qualifying status of a QF if appropriate. It may do so on its own initiative or if requested by some other party. It must first provide an opportunity for hearing.

\section{Federal Agency Contracts And PURPA}

Section 210(i) of PURPA relates to the effects of contracts between federal agencies and electric utilities on PURPA Section 210 implementation. Clauses in post-1978 contracts for the wholesale sale of electricity to a utility are voided to the extent they interfere with the utility's implementation of FERC's PURPA rules. The text of the provision is:

(i) Federal Contracts. - No contract between a federal agency and any electric utility for the sale of electric energy by such federal agency for resale which is entered into after the date of the enactment of this Act may contain any provision which will have the effect of preventing the implementation of any rule under this section with respect to such utility. Any provision in any such contract which has such effect shall be null and void.

"The term 'federal agency' means an executive agency (as defined in section 105 of Title 5 of the United States Code" (PURPA, Section 3(7)).

\section{Competitive Bidding}

In 1987, Martha Hesse, chairperson of the Federal Energy Regulatory Commission (FERC), proposed rules that would establish how state regulators allow independent power producers to competitively bid for the right to supply power to a utility. Although several states had established bidding programs prior to FERC's interest in the subject in order to bring order to the independent power market, FERC's proposed rules provided a catalyst for more states to become involved in competitive bidding. In theory, competitive bidding benefits consumers by establishing a market-based value for power and eliminating the risks to utilities associated with capacity expansion.

The process of competitive bidding begins when a utility identifies the need for new capacity. Well in advance of the date it begins to accept competitive bids, a utility typically publicizes the quantity and desirable attributes of its needed capacity, the terms of the offer to purchase capacity, participation criteria, and bid evaluation criteria.

Competitive bidding may affect PURPA development in several ways. Conpetitive bidding would likely affect the price paid for PURPA resources and therefore the return a PURPA de- 
veloper receives. For example, a developer wishes to build a QF. If the utility were to pay the developer a rate based on an administratively-determined avoided cost, the developer would receive a favorable return. However, if the rate were to be set through competitive bidding, the developer could conceivably eam a lower return. This type of situation would reduce incentives for developing PURPA resources. On the other hand, in a different situation, competitive bidding could increase the prices paid for non-utility generated power, thereby positively affecting the development of PURPA resources.

The actual influence of competitive bidding on price would depend heavily on how market forces replace administratively-set avoided costs and on what combination of least-cost resources are developed. For example, competitive bidding could lower a utility's marginal cost of electricity, resulting in higher profits. This improved profitability might lead the utility to purchase more power from PURPA resources, as long as the cost of those resources remains lower than the cost of utility-developed resources.

Cogeneration developers, whether a PURPA developer or successful competitive bidder, will need transmission access to deliver their product. PURPA only requires that utilities give transmission access to QF developers within the utility's own service area. Thus, if rules goveming wheeling are not changed and if provisions are not made for transmission and wheeling, the competitive bidding market will be severely limited since utilities might receive bids only from resources located within their own service areas.

\section{Revocation of Qualifying Status}

The Commission may revoke the qualifying status of a qualifying facility which has been certified under PURPA if the facility fails to comply with any of the statements contained in its application for Commission certification.

Prior to undertaking any substantial alteration or modification of a qualifying facility which has been certified under PURPA, a small power producer or cogenerator may apply to the Commission for a determination that the proposed alteration or modification will not result in a revocation of qualifying status.

\section{Natural Gas Policy Act of 1978 (NGPA)}

Title II of the Natural Gas Policy Act of 1978 (NGPA) provides that incremental cost increases incurred by natural gas suppliers as a result of the phased deregulation of natural gas wellhead prices (under Title I) must be passed through to customers buming natural gas in non-exempt industrial boilers and other non-exempt industrial facilities defined by FERC. The NGPA also authorizes FERC to exempt cogeneration facilities from incremental pricing. The incremental pricing rule applies only to boiler fuel use of natural gas used in large industrial boiler fuel facil- 
ities. However, "boiler fuel use" means the use of any fuel for the generation of steam or enlectricity. Natural gas use in combustion turbines and reciprocating engines may thus be defined as boiler fuel use.

FERC rules concerning cogeneration exemptions from incremental pricing are contained in 18 CFR 292.205, 18 CFR 292 (Subpart E) and 18 CFR 282. All topping-cycle cogeneration facilities which produce electricity may qualify for an exemption if the facility meets both the operating and efficiency standards specified by FERC under Section 201 of PURPA. However, the March 13,1980, installation date is not operative in determining compliance with efficiency standards for the incremental pricing exemptions.

For bottoming-cycle facilities, natural gas used for cogeneration is exempt to the extent that reject heat emerging from the useful thermal energy process is made available for power production. In other words, if half of the hot exhaust gases emerging from a high-temperature thermal process go into a heat exchanger for power production, the proportionately half of the natural gas input to the facility would be exempt. Since the incremental pricing rule applies only to industrial boilers, which are unlikely to be a heat source for a bottoming cycle, fuel if any bottomingcycle facilities would be subject to incremental pricing in the first place.

Under these rules, all gas used for supplementary firing is not exempt from incremental pricing. Of course, such gas may be exempt under other provisions of the incremental pricing rules.

Cogeneration facilities that were in existence on November 1,1979 , and used natural gas a fuel on or prior to that date may be exempted from incremental pricing under an Interim Rule that has been retained by the Commission. The Interim Rule, 18 CFR 292 (Subpart E), pertains only to incremental pricing. A facility qualifying under the Interim Rule does not gain the PURPA Section 210 benefits.

In brief, the Interim Rule consists of two alternative efficiency standards. A cogenerator can elect either standard, but all facilities must meet an efficiency test. The standards differ from the PURPA Section 201 efficiency standard in that:

- All fuels or energy inputs other than supplementary firing, are entered into the efficiency calculation

- Power outputs and thermal outputs are weighed equally (thermal energy is not divided by two)

- The ratio of energy outputs to inputs (deleting supplementary firing) must equal at least 0.55 , or in the alternative, 0.70 , after subtracting boiler efficiency considerations

- Gas used for supplementary firing may he exempted from incremental pricing under the Interim Rule. 
Cogeneration facilities producing no electricity may qualify for an exemption from incremental pricing under Order No. 104, issued on October 23, 1980 (45 FR 71787, October 30, 1980). The exemption afforded such mechanical cogeneration facilities is similar to that under PURPA Section 201, except that useful power outputs do include electricity.

\section{Regional Institutions}

There are two regional institutions in the Pacific Northwest that affect QFs. They are the Northwest Power Planning Council (NPPC) (created by the Northwest Power Act, P.L. 96-501, 94 stat. 2967; 16 USC 839-839h) and the region's federal power marketing agency, the Bonneville Power Administration (BPA). The NPPC is a planning authority. BPA provides electricity and transmission services.

The institutions are closely linked. The NPPC was created by the Northwest Power Act, P.L. 96501, 94 stat. 2967; 16 USC 839-839h. The Northwest Power Act's second and third resource priorities are "renewable resources" and "resources utilizing waste heat or generating resources of high fuel conversion efficiency." (Section 4(e)(1).) Also, Section 6(e)(1) says the BPA "Administrator shall, to the maximum extent practical,...(use his authority)...to acquire conservation... and renewable resources... and to provide credits and technical and financial assistance for the development and implementation of such resources..." The following definitions from Section 3 of the Act apply to most QF technologies, whether the power is for sale or on-site use.

(16) "Renewable resource" means a resource which utilizes solar, vvind, hydro, geothermal, biomass, or similar sources of energy and which either is used for electric power generation or will reduce the electric power requirernents of a consumer, including by direct application.

(19) "Resource" means -

(A) electric power, including the actual or planned electric power capability of generating facilities, or

(B) actual or planned load reduction resulting from direct application of a renewable energy resource by a consumer, or from a conservation measure.

All BPA-acquired resources must be cost-effective. The Act's cost-effectiveness standard is defined in Section 3 and appears below. On a conceptual basis, it is remarkably similar to PURPA's avoided cost standard as defined in 18 CFR 292.1()1(a)(6) and applied by 18 CFR 292.304.

(4)(A) "Cost-effective", when applied to any measure or resource referred to in this Act, means that such measure or resource must be forecast - 
(i) to be reliable and available within the time it is needed, and

(ii) to meet or reduce the electric power demand, as determined by the Council or the Administrator, as appropriate, of the consumers of the customers at an estimated increment $i$ system cost no greater than that of the least-cost similarly reliable and available alternative measure or resource, or any combination thereof.

(B) For purposes of this paragraph, the term "system cost" means an estimate of all direct costs of a measure or resource over its effective life, including, if applicable, the cost of distribution and transmission to the consumer and, among other factors, waste disposal costs, end-of-cycle costs, and fuel costs (including projected increases), and such quantifiable environmental costs and benefits as the Administrator determines, on the basis of a methodology developed by the Council as part of the plan, or in the absence of the plan by the Administrator, are directly attributable to such measure or resource.

(C) In determining the amount of power that a conservation measure or other resource may be expected to save or to produce, the Council or the Administrator, as the case may be, shall take into account projected realization factors and plant factors, including appropriate historical experience with similar measures or resources.

\section{Northwest Power Planning Council}

The Northwest Power Planning Council (NPPC) has three inissions, all of which affect QFs. They are the Power Plan, Fish and Wildlife Program, and Public Involvement Program. The regional Power Plan is periodically published by the NPPC. In it are forecasts of loads, evaluations of rescurces, a preferred supply strategy, and an action plan. The plan says how the renewable resources priority should be put into effect. The priorities will be important in determining how BPA acquires new resources. Except for conservation, the priority guides choices that cost the same. Conservation has a 10 percent cost advantage. Program directives are defined in the action plan, many of which address renewable resources issues. Resolving the issues can facilitate QF development.

The 1986 plan addressed the need for BPA to have the ability to acquire the capability of generating resources. Item 7 of the action plan set the following objective for BPA:

Develop an acquisition process and supporting activities designed to encourage the development of cost-effective priority resources, including conservation, renewables and high-efficiency resources, and lost opportunity resources, while also developing the capability to acquire conventional resources, when and if needed.

A number of activities were given to achieve the objective. Key among them, for QFs are:

...Develop a comprehensive acquisition process. An important part of any process to acquire resources is the purchase price of the resource. The concept, embodied in the Public Utility Regulatory Policies Act, of offering to pay the "avoided cost" (or what would have been 
paid for the development of the next planned resource), for qualified resources has been effective at encouraging the development of dispersed and renewable resources. Bonneville's acquisition process should embody this concept. Offering prices should be based upon the present value of these resources to Bonneville, including the effects of expected loads put on Bonneville by investor-owned utilities, and should consider characteristics of prospective resources which affect this value, such as dispatchability, and whether acquisition is constrained to a certain time period (a lost opportunity resource). Offering prices should be periodically adjusted to reflect changing demand forecasts, contracted loads and other conditions. The offer should include conditions to ensure that resource development is consistent with requirements of the plan and the Northwest Power Act.

Develop and demonstrate general approaches to contracting with utilities and independent power developers. When the region needs power, it is quite likely that utilities will not be the only developers of resources. Independent developers will likely sponsor many dispersed generating resources, conservation resources and, possibly, central station power plants. The intent of this activity is to encourage the orderly development of small-scale and high priority resources and to identify and acquire lost opportunity resources as these become cost effective.

\section{Bonneville Power Administration}

The Bonneville Power Administration (BPA) is the Northwest's federal power marketing agency. In this role it supplies most of the electricity that customer-owned utilities (COUs) sell retail customers. In fact, most utilities throughout the region obtain at least some power from BPA. BPA supplies 48 percent of the region's power. The regional transmission grid is operated by BPA and transmission services are extensively used by utilities. To some extent transmission services are also available to QFs.

The Northwest Power Act expanded the role of BPA in the region. Prior to the Act, BPA's main function was to distribute generation from federally-owned dams. Now, BPA is involved in many activities that affect QFs. BPA has sponsored numerous studies of renewable resources throughout the region. Resources and technologies that have been studied include hydropower, wind, cogeneration, geothermal, and municipal solid waste. The results of these activities can be very useful to $Q F$ developers.

In response to the NPPC's Power Plan, BPA is working on a resources acquisition policy and program. When fully implemented, the BPA acquisition process will be one way for resource developers to market the output from renewable resource generation projects. Section 6 of the Northwest Power Act covers resources acquisition and the process will need to conform to the Act. The first BPA competitive acquisition process calling for the purchase of resources was announced in 1991. 


\section{State Agencies and Regulations}

In addition of the federal regulations described previously, regulations at the State level would also be applicable to cogeneration facilities and may in some cases be more stringent than the federal regulations. Regulations vary from state to state depending upon specific environmental problems within the state or region, types of industries in the state, and type of fuels available. 


\section{Permit Summary Sheet IDAHO}

Agency

AIR QUALITY

Air Quality Permit

IDHW

WATER QUALITY/WATER USE

Public Water Supply License

Water Appropriation Permit

Stream Channel Alteration

Compliance with Idaho State

Water Plan

Compliance with the Idaho Comprehensive

State Water Plan

LAND USE

Soil and Water Conservation District

Land Use Regulations

Cooperative Unit Agreements

Floodplains and Floodway Permits

Historical Sites Permits

State-Owned Lands (permits, keases,

easements)

Local Zoning and Land Use Regulations

CONSTRUCTION

Highway Encroachment Easements

Overhead Lines

Highway Utility Easements

Lakeshore Work Permits

Wastewater Treatment/Subsurface

Disposal

Building Permits

Mechanical, Electrical, and Plumbing

Permits

Non-navigational or Commercial

Navigational Encroachment

FISH/WILIDLIFE

Fish and WillDLife Impact Evaluation

FOREST AREAS

Timber Removal/Slash Disposal Permit

SAFETY/HEALTH

Dam Safety Construction/Operation Permits

Solid Waste Permit

Waste Disposal Permit

Hazardous Waste Permit

Boiler License

OTHER

Cogeneration \& Small Power Production

Facilities Certification

\begin{tabular}{|c|c|c|c|c|c|}
\hline $\begin{array}{l}\text { Thermal } \\
\text { Resources }\end{array}$ & $\begin{array}{l}\text { Trans- } \\
\text { mission } \\
\text { Lines }\end{array}$ & Hydro & $\begin{array}{l}\text { Cogen- } \\
\text { eration }\end{array}$ & Wind & Biomass Geotherma \\
\hline
\end{tabular}

\section{IDHW \\ IDWR}

IDWR,IDL

IDWR

IDWR

LA
IDWR
IDWR,LA
ISHPO

IDL.

LA

\section{LA, ITD}

LA,ITD

LA, ITD

LA,IDL

IDHW,IDWR

LA,IDLIS

LA,IDLIS

IDL

IDFO

IDL

IDWR

IDHW

IDWR

IDHW

IDLIS

IPUC

\section{Agencles}

LA

Local agencies

IDWR Idaho Department of Water Resources

IDHW Idaho Department of Health and Welfare

IDLIS Idaho Department of Labor and Industrial Services

IDL IDAHO Department of Lands

IPUC Idaho Public Utilities Commission

ISHPO State Historic Preservation Office

ITD Idaho Transportation Departmen

IDFO Idaho Department of Fish and Game

\section{Key}

$\dagger=$ Permit required

- = Permit may be required

* = Site specific 


\section{Chapter 2 The Idaho State Process}

This chapter serves as a guide for understanding state and local requirements for the development of energy facilities in Idaho. These requirements are concerned with a wide variety of issues such as construction, legal rights, public safety, and environmental concerns.

The Idaho section is organized into three parts: state agencies, state permits and licenses, and local permits and licenses. A brief description of each agency involved in regulating cogeneration development are summarized under Idaho's State Agencies Responsibilities below. The agencies are listed in alphabetical order rather than in order of importance to the cogeneration developer. State permits are listed under Idaho State Permitting and Licensing Requirements on page 43. Local permits are listed starting on page 63.

The time required for obtaining all permits, licenses and/or approvals may be a substantial part of the total project duration. Therefore, it is important for the site developer to initiate the permitting process in the early stages of project development. Specific time requirements may be found in the sections describing the individual permits.

\section{Idaho State Agencies' Responsibilities}

There are approximately ten state agencies involved in regulating energy facilities. Although these agencies have potential permitting or review authority, cogeneration facilities are likely to require only a few permits and/or licenses. The primary state agencies regulating cogeneration development are the Idaho Department of Health and Welfare; the Idaho Department of Water Resources, Energy Division; and the Idaho Public Utilities Commission. Other state agencies that may require permits or otherwise act in a review capacity include the Idaho Department of Labor and Industrial Services, the Idaho Department of Lands, the Idaho Department of Fish and Game, the Idaho Department of Parks and Recreation, the Idaho Office of Secretary of State, the Idaho State Historic Preservation Office, and the Idaho Transportation Department.

\section{Agency: Idaho Department of Fish and Game (IDFG) Statutory Authority: Title 36, Idaho Code}

The Idaho Department of Fish and Game (IDFG) is responsible for protecting and enhancing fish and wildlife populations and habitats. Discharge of effluents or brines into natural water courses or wetlands can cause water quality problems, such as poor water chemistry, algal blooms, decreased dissolved oxygen content, increased water temperatures, or increased turbidity. The water quality standards set by the Idaho Department of Health and Welfare address these concerns with respect to both fisheries and human needs. 
Agency: Idaho Department of Health and Welfare (IDHW)

Statutory Authority: Section 39-3601 et seq., Idaho Code

As required by the Clean Water Act and the Clean Air Act, applications for energy project development must obtain certification that the proposed project will not cause any violation of state water or air quality standards. In Idaho, certification can be obtained from the Division of Environmental Quality of the Idaho Department of Health and Welfare (IDHW). Water quality standards are not the same for all streams in the state, and clarification of the appropriate standards should be obtained prior to application. Authorization for temporary violation of water quality standards, as would likely occur during construction, must also be obtained.

It may be advisable for projects involving significant environmental impacts to retain the services of an expert environmental consultant to help in gathering necessary information and in recommending mitigative measures. Agencies themselves also have environmental specialists who can assist in determining what information needs to be collected.

\section{Agency: Idaho Department of Labor and Industrial Services (IDLIS)}

Building construction and mechanical, plumbing, and electrical permits are based on compliance with state codes and are administered by the state Idaho Department of Labor and Industrial Services (IDLIS).

Agency: Idaho Department of Lands (IDL)

Statutory Authority: Sections 47-701 et seq., Idaho Code; Section 47-1601 et seq., Idaho Code; and Title 58, Idaho Code

If state land is involved in proposed cogeneration development, either for the power plant, road access, transmission line right-of-way, or pipelines for transporting brine or steam, necessary use permits and leases will need to be negotiated through the Idaho Department of Lands (IDL).

\section{Agency: Idaho Department of Parks and Recreation (IDPR) Statutory Authority: Sections 67-4201, Idaho Code; and Section 67-4301 et seq., Idaho Code}

The Idaho Department of Parks and Recreation (IDPR) is responsible for reviewing proposed projects for impacts on recreation. It can impose conditions to enhance the recreational potential of a stream or adjoining land, or it can impose mitigative measures to lessen adverse impacts. 
Agency: Idaho Department of Water Resources (IDWR) Statutory Authority: Title 42, Idaho Code

The Idaho Department of Water Resources (IDWR) administers the water appropriation permits program. It has several other public service oriented programs that are applicable to cogeneration development including those of the Energy Division.

\section{Agency: Idaho Department of Water Resources, Energy Division} Statutory Authority: Executive Order \#76-4; Executive Order 80-10

The Idaho Energy Division was created in February 1974. The office originally functioned as part of the Governor's Office. Subsequently, it was transferred to the Public Utilities Commission, but again was transferred back to the Governor's Office by Executive Order 76-4 in 1976.

In 1981, through Executive Order 80-10, the Idaho Office of Energy merged with the Idaho Department of Water Resources (IDWR). The newly-formed Energy Bureau existed until 1989, at which time it was elevated to division status.

The Energy Division's mission places emphasis on energy conservation activities and the use of renewable resources.

\section{Agency: Idaho Office of the Secretary of State}

Statutory Authority: Section 30-155, Idaho Code; Section 53-213, Idaho Code; and 48-501 et seq., Idaho Code

The Idaho Office of the Secretary of State handles such items as the filing of Articles of Incorporation/Certificates of Limited Partnerships, and the Registration of Trademarks.

\section{Agency: Idaho Public Utilities Commission (IPUC) Statutory Authority: Title 61, Idaho Code}

The Idaho Public Utilities Commission (IPUC) plays a strong role in energy facility siting and regulations. It has been very supportive of small power producers and has been an early leader in implementing the Public Utilities Regulatory Policy Act (PURPA). While no standard form contract is enforced, the IPUC has encouraged Idaho utilities to bargain in good faith with small power producers.

Contracts between a small power producer and a regulated utility must be approved by the IPUC. The IPUC has jurisdiction over the prices paid by investor-owned utilities for power purchased from electric generation facilities and over the rates and charges levied by investor-owned utilities on generation project developments for interconnection, line maintenance, and the supply of back-up power. The IPUC can also be helpful in identifying utilities that might be possible buyers of new electrical energy. 
Before an electrical corporation or water corporation begins constructing a line, plant, or system or extension of same, it must first obtain from the IPUC a certificate that the present or future public convenience and necessity require or will require such construction (Idaho Code $\$ 61$ 526).

Agency: Idaho State Historic Preservation Office (ISHPO)

Statutory Authority: Section 67-4101 et seq., Idaho Code; and Section 67-4601 et seq., Idaho Code

State and federal law protects historical and archaeological sites as well as National Register properties. The Idaho State Historic Preservation Office (ISHPO) has responsibility for reviewing the impacts of proposed projects and any avoidance, mitigation, or protective measures proposed by the applicant.

\section{Agency: Idaho Transportation Department (ITD)}

Statutory Authority: Title 49, Idaho Code

The Idaho Transportation Department (ITD) regulates construction and maintenance of a new and existing roads under state jurisdiction, and the placement of utility easements on those roads. Some roads are not under the jurisdiction of the state but under local jurisdiction. The ITD can advise as to who has jurisdiction.

Also, the ITD licenses and regulates commercial vehicles on highways.

\section{Idaho State Permitting and Licensing Requirements}

The permits, licenses and/or approvals are categorized by type. The categories, as well as the permits, are listed in alphabetical order. Specific time requirements are found at the end of each description. For more information on these permits, contact the agency listed. Addresses and telephone numbers can be found on page 212 .

\section{Air Quality}

Permit or Regulation: Permit to Construct

Statutory Authority: Section 39-115, Idaho Code

Agency: Idaho Department of Health and Welfare (IDHW)

Any owner/operator of a facility that emits or may emit an air contaminant such as dust, fumes, gas, mist, odor, smoke, vapor, pollen, soot, carbon, or particulated matter must apply for a Permit to Construct. Some exclusions are available and include: 
- fuel burning equipped for indirect heating and for heating and reheating furnaces using gas exclusively, with a capacity of less than 5() million Btu per hour input

- other fuel burning equipment for indirect heating with a capacity of less than 1 million Btu per hour input

- mobile internal combustion engines

- pilot plants, with written approval from the administrator renewable annually, the products from which are not offered for sale except in developmental quantities.

There are several levels of air quality permitting that are handled in the single permit application process. Not all of these will be applicable to every application. These include:

- Non-Attainment Area Review

- New Source Performance Standard

- National Emission Standards for Hazardous Air Pollutants

- Prevention of Significant Deterioration

- State Regulations, including Operating Permit.

\section{Prevention of Significant Deterioration (PSD)}

Prevention of Significant Deterioration (PSD) permitting is required for all developments defined as a major facility. Major facilities include, but are not limited to, any designated stationary source of air pollution emitting or having the potential to emit 100 tons or more per year of any pollutant subject to regulations. Such facilities include:

- combined fossil and biomass boilers totaling more than 250 million Btu per hour heat input

- fuel conversion plants

- municipal incinerators capable of charging more than 250 tons of refuse per day.

Also defined as major facilities are any other stationary sources that emit or have the potential to emit 250 tons per year of any pollutant subject to regulation.

An additional consideration in the PSD evaluation process is necessary if the facility will be constructed in or near a Class I area. Different air quality standards will apply in such a case, and the federal land manager responsible for the Class I area (e.g., U.S. Forest Service, National Park Service) will be involved in the permitting process.

\section{Non-Attainment Area Review}

Non-Attainment Area Review is applicable only to those facilities proposed to be located in an Environmental Protection Agency designated non-attainment area of the state. There are three such areas:

- Ada County (Boise) for carbon monoxide (CO)

- Don Siding (Pocatello) for total suspended particulates (TSP)

- Conda (Soda Springs) for total suspended particulates (TSP). 
Non-Attainment Area Review requires that four conditions be met, at least one of which will be outside the applicant's control.

- enforcement of an approved State Implementation Plan (SIP) containing growth provisions pertinent to the Non-Attainment area

- application of Lowest Achievable Emission Rates to the proposed facility

- compliance of all sources owned by the applicant that are located in the state with appreciable air emission regulation

- emission offsets (reduction in emission already occurring in the area) if at least 120 percent and demonstrated commensurate improvement in air quality.

\section{New Source Performance Standards (NSPS)}

Review is the most straight-forward of the evaluations since it requires a comparison of projected potential emissions from the new facility with an established emission standard for the particular type of facility.

In PSD permitting, location of the facility, topography, and meteorology of the area are extremely important to determine the applicable increment of allowable air quality deterioration.

If adequate data on background levels is not already available, which is usually the case, air quality monitoring by the applicant for up to one year may be required.

Emission control technology to be used on the facility must conform to the Best Available Control Technology (BACT) as determined on a case-by-case analysis. Allowable pollution increments for Idaho are given in Table 2.

The Idaho Department of Health and Welfare, Air Quality Bureau provides a standard application form for all air quality permits.

Information is required about the applicant; the proposed project; facilities operating within the state owned by the applicant; fuel burning equipment; estimated emissions; producing and manufacturing operations; refuse disposal and incineration, storage, handling, and use of volatile organic compounds; loading racks and oil-water separators; hazardous/toxic materials; and material transport and handling.

If PSD regulations are applicable, data on baseline air quality conditions must be provided. If PSD compliance is necessary, monitoring of baseline (existing) air quality conditions in the project area for up to a year may be necessary.

New Source Performance Standards applicability includes, but is not limited to:

- electric utility steam generating units with a heat input greater than 250 million But/hour of fossil fuel alone or in combination with any other fuel 
Table 2

Allowable PSD Increments $\mathrm{Mg} / \mathrm{m}^{3}$

Sulfur Dioxide

Annual

24 hour

3 hour

Total Suspended

Particulate Matter

Annual

24 hour

\begin{tabular}{r} 
Class I \\
\hline 2 \\
$5 \mathrm{a}$ \\
$25 \mathrm{a}$
\end{tabular}

5 a

10 a

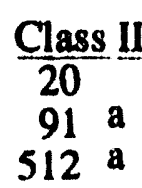

512 a

19

$37^{a}$ $\frac{\text { Class ஹI }}{40}$

182 a

700 a

a Not to be exceeded more than once a year

b No Class III lands are designated in Idaho

- storage vessels for petroleum liquids with a capacity greater than 40,000 gallons.

National Emission Standards for Hazardous Air Pollutants (NESHAPS) apply at present only to facilities handling:

- asbestos

- berylliuin

- mercury

- vinyl chloride

Approximate Time for Permit Process

Once an application for a Permit to Construct is received, the IDHW has $\mathbf{3 0}$ days to review for completeness. Once an application is accepted as complete, the IDHW has 60 days in which to evaluate the application before notifying the applicant of its decision to approve or deny the permit. In the case of facilities that would cause substantial air quality impacts or affect a Class I area, a 30-day period for public comment following notice must be provided before a determination is made.

\section{Cogeneration Facility Siting/Environmental Impact}

\section{Energy Facility Siting}

Idaho has no facility siting agency, but the Idaho Public Utilities Commission plays a strong role in facility siting. 
Permit or Regulation: Environmental Reporting/Compliance with the

National Environmental Protection Act (NEPA)

Statutory Authority: 42 United States Code 4321

Agency: Varies

Because the state of Idaho does not have statewide environmental review requirements, certain projects will require environmental review on the federal level. The federal approvals/permits required for a project that could trigger environmental reporting requirements, the U.S. Army Corp of Engineers 404 Permit, and in some cases, the National Pollutant Discharge Elimination System Permit. Prevention of Significant Deterioration permits are exempt for NEPA compliance.

The key issue is whether the proposed federal agency action constitutes a major federal action that significantly affects the quality of the environment. If the action is not significant, the agency may choose to issue a Finding of No Significant Impact (FONSI) in lieu of an environmental impact statement. Other options include enclosing an environmental impact statement prepared by another federal or state agency on the same project (see the Federal section of this book, pages 7 through 38).

\section{Construction}

\section{Permit or Regulation: 404 Permit}

Statutory Authority: 33 United States Code 401-1241; 33 CFR 320 and 322 through 329

Agency: U.S. Army Corps of Engineers; Idaho Department of Water Resources (IDWR)

Construction of structures within, dredging, and filling of navigable waters or wet lands as classified by the U.S. Amy Corps of Engineers (COE) requires a 404 Permit. These are permitted by the COE, depending on the complexity of the activity. General, Regional, and Nationwide Permits allow more common, generic types of activities without formal evaluation. The individual permit must be obtained for larger, more unusual actions that could result in major impacts to the waterway.

The basis for evaluating the permit application include effects of the activity on:

- the public interest and use of the water way resource

- the resources of wet lands

- fish and wildlife

- water quality

- historic, cultural, scenic, and recreational values

- adjacent properties or water resource projects

- other federal, state, or local requirements

- flood plain management 
- water supply and conservation

- energy conservation and development

- navigation

The availability of alternative methods that would result in less harmful effects is also an important consideration.

A standard form must be completed and submitted together with maps, plans, and specifications for the activity relating to its effect on the wetlands and/or waterway. If a Stream Channel Alteration Permit and/or State Land Easement or Special Permit is required for the activity, a joint application for the permit can be filed with the Department of Water Resources (IDWR) and copies will be sent to the other agencies. The IDWR will coordinate the process of the permit application.

Upon receipt of the completed application, the regional COE office will publish a public notice of the applications and request input from regulating agencies, individuals, and interest groups with a 15 to 30 day period. Substantial objections will result in a public hearing being held. Objections from public agencies must be resolved before the permit can be issued.

Approximate Time Required for Processing

Most permits will be issued within 60 days of application, although more contro-versial projects may take 120 days or longer.

\section{Permit or Regulation: Approval of Wastewater Treatment System and Subsurface Disposal System \\ Statutory Authority: Section 39-118, Idaho Code \\ Agency: Idaho Department of Health and Welfare (IDHW)}

All above-ground wastewater treatment systems must be approved by the Idaho Department of Health and Welfare (IDHW). Subsurface systems, except for injection wells, must be approved by the appropriate district offices.

Plans for above-ground treatment systerns must be submitted to the appropriate field office of IDHW. For a subsurface disposal system, the legal description of the property, information regarding the amount of water to be used, a plot plan of the proposed layout, and a description of soil types must be submitted.

\section{Approximate Time Required for Processing}

For above-ground systems, IDHW engineers will review and approve or request modification of the plans within a 30-day period. Subsurface systems will generally be reviewed and approved or directed to be modified at the time the application is submitted. 
Permit or Regulation: Building

Statutory Authority: Title 39, Chapter 41, Idaho Code

Agency: Idaho Department of Labor and Industrial Services (IDLIS)

The issuance of a building permit is based on the compliance of proposed plans with adopted building codes. In some counties, the building permit is administered by the Idaho Department of Labor and Industrial Services (IDLIS).

Approximate Time Required for Processing

Issuance of a building permit for industrial use can be expected to take several weeks after submittal of the building plans.

\section{Permit or Regulation: Highway Encroachment Easements}

Statutory Authority: State of Idaho Right-of-Way Use Policy, Section 12-450 through 451, Idaho Code

Agency: Idaho Transportation Department (ITD)

Any person or agency planning to access a highway or use a highway right-of-way for any purpose other than travel, must obtain an approved Application and Permit to Use Right-of-Way.

A sketch should be provided by the applicant showing the location of existing and proposed $p$ proach changes, location of other proposed work to be done within the highway right-of-way and highway signs in the area of the approach, as well as the costs of studies or appraisals when large development plans must be reviewed and/or extensive Idaho Transportation Department (ITD) time is expected on a traffic study or review. The ITD may require reimbursement for inspection time and travel costs. The intent is to recover ITD cost only. Application will not be processed before payment of the nonrefundable application fee.

The ITD reserves the right to make any changes, additions, repairs, or relocation to any approach or its appurtenances within the highway right-of-way necessary relocation, reconstruction, widening, or maintenance of the highway and/or to provide proper protection of life and property on, or adjacent to, the highway.

\section{Approximate Time Required for Processing}

Application for highway encroachment easements can take several days to several weeks to process, depending upon the complexity of the project. 
Permit or Regulation: Highway Utility Easements

Statutory Authority: Section 40.312(3), Idaho Code; Section 42-3212, Idaho Code;

Sections 62-701 through 705, Idaho Code; and Section 62-1101, Idaho Code

Agency: Transportation Board; Idaho Transportation Department (ITD)

Highway utility easements relate to the manner in which utility installations are to be made within the right-of-way of state highways when such use and occupancy of the highway right-of-way is deemed to be in the public interest, and will not adversely affect the highway or its users.

Utilities must be located to minimize the need for adjustments for future highway improvements, avoid interference with highway maintenance or signing, and permit access to the utilities for their maintenance with minimum interference to highway traffic.

The utility company or independent power developer is responsible for the design of the utility facility to be installed within the highway right-of-way or attached to a highway structure. The Idaho Transportation Department (ITD) is responsible for review and approval of the proposal with respect to the location of the utility facilities to be installed and the manner of attachment. This includes the measures to be taken to preserve the safe and free flow of traffic, structural integrity of the roadway or highway structure, ease of highway maintenance, appearance of the highway, and the integrity of the utility facility.

Facilities located on or across highways for which deeds of right-of-way have not been obtained, such as through National Forest Service (NFS) lands, U.S. Bureau of Land Management (BLM) land, etc., shall require a grant of right-of-way for non-highway purposes from the appropriate governmental agency having administration of the lands.

Facilities located on or across highways which are located on railroad property will require the approval of the railroad company.

Each new utility installation which is to occupy highway right-of-way requires a permit. The permit must, as a minimum, describe the ITD standards for location, construction, protection of traffic, maintenance, access restrictions, and any special conditions applicable to each installation.

The permit application must include detailed drawings or sketches showing the location of the proposed facility with respect to existing and/or planned highway improvements, the traveled way, horizontal and vertical clearance, the right-of-way lines and, where applicable, the access control lines and approved access points. When attachment to a highway structure is proposed, details of the attachment method must be included for approval by the ITD r rior to installation. The permit application must also include traffic control plans for any work to be performed within the highway right-of-way.

When a proposed facility involves a pipeline carrying potentially hazardous materials, the following additional data are required: 
- contents to be transported

- pipe size, nominal

- wall thickness

- location class and construction type

- design pressure (maximum operation pressure)

- maximum actual working pressure.

When indicated on the permit, the permittee must take out and maintain property damage and public liability insurance. The permittee may also be required to furnish a surety bond in the amount specified in the special provisions of the permit for installation and future repair, relocation, or removal of the facilities.

\section{Permit or Regulation: Mechanical/Plumbing/Electrical Permits}

Statutory Authority: Title 39, Chapter 27, Idaho Code; Title 54, Chapter 10, Idaho Code Agency: Idaho Department of Labor and Industrial Services (IDLIS)

Mechanical, plumbing, and electrical permits are based on compliance with state codes and are administered by the state Idaho Department of Labor and Industrial Services (IDLIS). The permits are issued directly to the contractor rather than to the owner/operator of the facility being constructed.

Approximate Time Required for Processing Issuance of these permits should not take longer than 2 weeks after submittal of the completed application.

\section{Permit or Regulation: Motor Vehicles}

Statutory Authority: Title 49, Idaho Code Agency: Idaho Transportation Department (ITD)

Commercial Vehicle Licenses - Special vehicle licenses are required for any commercial vehicle.

Temporary Trip Permit - This is required for all commercial vehicles licenses in other states and operating in Idaho. Permits can be purchased at ports of entry and other truck checks within the state for $\$ 12$ plus a fee based on combined gross weight and mileage.

Oversize Permit - Without an oversize permit, maximum width for a commercial vehicle is 8'6" wide, 14' high, $48^{\prime}$ ' long on a single trailer or 60 ' long on a double trailer, unless the overall length including the coupling is $75^{\prime}$ or less. Some roads cannot be traveled by an oversize vehicle. This is an annual permit.

Overweight Permit - Normal permitted weight for a commercial vehicle is $80,000 \mathrm{lbs}$. An extra weight permit may be obtained, but does not allow the holder to exceed the legal access weight (weight per axle). Some roads cannot be traveled by an overweight vehicle. 


\section{Fish/Wildlife}

Permit or Regulation: Fish and Wildlife Impact Evaluation

Statutory Authority: Sections 36-103 et seq., Idaho Code

Agency: Idaho Department of Fish and Game (IDFG)

In Idaho, all wildlife, including wild animals, wild birds, and fish are declared to be the property of the state. The Fish and Game Commission, acting through the Idaho Department of Fish and Game (IDFG) implements and enforces regulations regarding fishing and hunting, and also carries out actions to protect and enhance fish and wildlife populations and their habitats.

While regulations and IDFG authority is quite specific with regard to harvest, transport, capture, and management of fish and wildlife populations, IDFG's authority to manage habitat is not as clearly defined.

Since fish and wildlife habitats are generally controlled by state or federal land and water management agencies, the IDFG frequently exercises its influence through the regulatory processes of these agencies. By influencing how habitats are managed, the IDFG can effectively manage fish and wildlife populations and the effects caused by any facilities constructed in these areas. To illustrate, the IDFG could act as an intervener in proceedings before other agencies to acquire air, water, waste, or other permits.

There are no permits issued by IDFG to certify that fish and wildlife impacts have been adequately mitigated or do not exist. Nevertheless, because the agency can and will influence various aspects of the project through their actions, developers are strongly encouraged to consult with the agency very early in the planning process. The IDFG will closely coordinate with other agencies as appropriate.

\section{Forest Areas}

Permit or Regulation: Slash Disposal Permit

Statutory Authority: Title 38, Chapters 1 and 4, Idaho Code

Agency: Idaho Department of Lands (IDL), Board of Land Commissioners

Any burning operation conducted for the purpose of hazard reduction shall be in accordance with the law requiring burning permits during the closed fire season. Persons conducting burning operations must have sufficient men, tools, and equipment on hand to immediately stop the uncontrolled spread of fire. Burning operations shall be planned, prepared, and executed in such a manner that forest resources are not damaged and air quality standards are met. 
Permit or Regulation: Timber Removal

Statutory Authority: Title 38, Chapters 1 and 4, Idaho Code; IDAPA 24.19

Agency: Idaho Department of Lands (IDL), State Board of Land C'ommissioners

A permit is required from the Idaho Department of Lands (IDL) for timber cutting on state granted easements or right-of-ways.

\section{Land Use}

Permit or Regulation: Floodplain Development

Statutory Authority: National Flood Insurance Act of 1968; Flood Disaster Protection Act of 1973; Local County and City Ordinances

Agency: Idaho Department of Water Resources (IDWR); Local Governments

The appropriate local authority will review all plans to ensure that any changes proposed or structure to be constructed will not have an adverse effect upon flooding. One key element is that the capacity of streams cannot be changed.

Approximate Time Required for Processing

Permits will generally be approved within 6 weeks.

Permit or Regulation: Historical Site Permit

Statutory Authority: Section 106 of the National Historic Preservation Act of 1966;

36 CFR 800 "Procedure for the Protection of Historic and Cultural Properties" Agency: Idaho State Historic Preservation Office (ISHPO)

After being notified of a proposed project, the Idaho State Historic Preservation Office (ISHPO) will check inventory and survey records to determine if surveys have been conducted and whether archaeological sites on historic properties have been identified in the project area.

In some cases, professionals from the ISHPO will inspect a project area to help a private firm or individual comply with federal preservation laws. If a proposed project requiring federal approval or a federal license is not on federal land, is not federally funded, and if it is less than 25 acres in size, the ISHPO will consider inspecting the project at no cost to the applicant.

Approximate Time Required for Processing

Normally 30 days. Allowances are made in cases where the normal review period would cause a delay in a project. 
Permit or Regulation: State Land Easement

Statutory Authority: Title 58, Idaho Code

Agency: Idaho Department of Lands (IDL)

Whenever construction occurs below the mean high water mark of a river or encroaches on other state lands, an easement must be secured. A fee is charged based on the land's fair market value.

Approximate Time Required for Processing

Approximate time to process the permit application is several days to several weeks, depending on the complexity of the project.

\section{Safety/Health}

\section{Permit or Regulation: Boiler Safety}

Statutory Authority: Section 67-5204 as amended, Idaho Code

Agency: Idaho Department of Labor and Industrial Services (IDLIS)

All boiler and pressure vessels manufactured or installed in the state of Idaho or shipped into Idaho must be constructed in accordance with the requirements of American Society of Mechanical Engineers (ASME) Boiler Code (1983) and bear the stamp of the National Board of Boiler and Pressure Vessel Inspectors.

All boilers and pressure vessels must be installed and maintained in conformity with the requirements of the ASME Boiler Code (1983), and Chapter I through IX of the National Board of Boiler and Pressure Vessel Inspectors Inspection Code (1983) and Idaho Code 67-5204.

All welding and installation of boilers and power piping shall be in strict accord with the ASME Boiler and Pressure Code (1983), and the ASME Power Piping Code (ANSI B 31.1-1983). Each manufacturer and contractor shall be responsible for the welding done by his organization and shall have each welder tested in accordance with ASME requirements prior to performing and welding covered under Idaho Code 67-5204.

All boiler and pressure vessels installed or operated in the state of Idaho shall have an inspection conducted by a person holding a certificate of competency which must result in the issuance of a certification of inspection before such vessel is placed in operation. Whenever an inspection is made by a person holding a certificate of competency, a copy of the inspection report shall be submitted on forms as outlined in the National Board Inspection Code. Boiler inspections are done by certified inspectors in the employment of insurance companies who insure the boilers.

Boilers that do not specifically contain all the fail-safe features necessary to operate fully unattended shall have qualified boiler attendants. 


\section{Permit or Regulation: Hazardous Waste}

Statutory Authority: Sections 39.4401 and 5800 et seq., Idaho Code;

Federal Resource Conservation and Recovery Act 42 USC 6901

Agency: Idaho Department of Health and Welfare (IDHW);

\section{Environmental Protection Agency (EPA); Hazardous Waste Board}

Owners or operators of facilities that provide treatment, storage, or disposal of more than 220 pounds of hazardous waste per month must have a Hazardous Waste Permit from the Idaho Department of Health and Welfare (IDHW). Generation of less than 220 pounds per month is exempt from most hazardous waste standards and permitting requirements if the disposal of the waste is on-site or at a state approved disposal site for hazardous waste, or if the waste is treated on-site.

The permit application will be evaluated on the type of waste to be handled, security procedures proposed, plans for periodic inspection of the facilities, plans for preventive action and emergencies, design and layout of facilities, geologic and hydrologic information, safety training program for personnel, and plans for closure of the facility. Impacts on groundwater and soils will be closely evaluated.

Applications must be submitted to the IDHW and the Environmental Protection Agency (EPA). Once a completed application is accepted by IDHW, the IDHW must act on the application within 120 days or refer it to the Hazardous Waste Board for review and action within 120 days.

\section{Approximate Time Required for Processing}

The application process can be expected to take up to 1 year. EPA process of an application of the federal permit should require a similar amount of time.

\section{Permit or Regulation: Solid Waste}

Statutory Authority: Section 39-105, Idaho Code

Agency: Idaho Department of Health and Welfare (IDHW)

Any land area used for the storage, transfer, processing, separation, incineration, or disposal of solid waste having no intended future use must be approved by the Idaho Department of Health and Welfare (IDHW).

The issues involved in obtaining a permit deal with existing environmental and land use conditions in the area. These include depth to groundwater, soils conditions, prevailing winds, type of and distance to nearby land uses, etc., as well as proposed design and operation procedures, and restoration plans.

A complete application must be submitted on a standard form and must provide plans, maps, specifications, and proposed operational procedures. Applications should be submitted to the 
IDHW or to the local health district at least 30 days prior to the date of expected action. The application must be accompanied by a statement from the local land use authority(s) regarding compatibility with existing planning and zoning ordinances.

The application must be approved by the land owner, county commissioners, and local health district office before the IDHW will approve.

\section{Water Quality/Water Use}

\section{Permit or Regulation: Compliance with the Idaho Comprehensive State Water Plan Statutory Authority: Section 42-1734 et seq., Idaho Code Agency: Water Resource Board}

The purpose of the comprehensive state water plan is to plan for the conservation, development, management, and optimum use of all unappropriated water resources and waterways in the public interest. The plan contains a description of existing and planned uses, and the impact of such uses at the local, state, and regional level. The plan quantifies, insofar as possible, the unappropriated waters of the planning area and plans the allocation of such waters among the various competing uses.

As part of the plan, selected waterways have been designated as protected rivers. Protected rivers can be either a natural or a recreational river. A natural river is defined as a waterway which possesses outstanding fish and wildlife, recreational, geologic, or aesthetic values. The waterway must be free of substantial man-made impoundments, dams, or other structures and of which the riparian areas are largely undeveloped, although accessible in places by trails and roads. A recreational river is similar to a natural river, except that it might include some manmade development within the waterway or within the riparian area of the waterway.

Proposed projects would be evaluated for their effect on fish and wildlife, recreational, aesthetic, historical, cultural, natural or geologic values of the waterway. For rivers designated as natural, the following activities are prohibited:

- construction or expansion of dams or impoundments

- construction of hydropower projects

- construction of water diversion works

- dredge or placer mining

- alterations of the stream bed

- mineral or sand and gravel extraction within the stream bed.

In designating a recreational river, the Water Resource Board will determine which of the activities listed above shall be prohibited and may specify the terms and conditions under which activities that are not prohibited may go forward. 
Review for compliance with the comprehensive state water plan is started by filing a water rights application. If a proposed project has some potential for conflict with the plan, the director, can recommend review by the board.

\section{Approximate Processing Time Required}

Since review is concurrent with review of a water appropriation permit, processing time can vary depending upon whether protests are filed against the permit application. As the plan is more restrictive in regard to natural rivers, processing should be relatively quick. However, since the Board may need to develop terms and conditions for projects on recreational rivers, processing times will be longer.

\section{Permit or Regulation: National Pollution Discharge Elimination System (NPDES) Statutory Authority: 33 United States Code 1251; 40 CFR 125 Agency: Idaho Department of Health and Welfare (IDHW); U.S. Environmental Protection Agency (EPA)}

The owner/operator of any proposed cogeneration development that will discharge wastewater into surface waters by way of a discrete conveyance (pipe, ditch, etc.) must first obtain a National Pollution Discharge Elimination System Permit (NPDES). A separate application is required for each facility in the operation discharging separately.

The NPDES permit process addresses the amount of pollutants to be discharged to surface waters. Important considerations include the content of the process effluent; proposed treatment prior to discharge; and the particular body of water into which the discharge will be made.

For most operations, "best management practices," including schedules of activities, prohibitions or practices, maintenance procedures, and other management practices to prevent or reduce the pollution of surface waters must be implemented. Monitoring and reporting of discharge is required as is annual reporting of compliance with the regulations.

Applicants are to register with Environmental Protection Agency (EPA) and the Idaho Department of Health and Welfare (IDHW) at least 180 days prior to construction of the proposed operation. Information to be submitted includes:

- information about the owner, operator, and facility

- $\quad$ proposed treatment for processing wastes

- description of proposed runoff storage facility, including area drained, capacity, and design safety considerations

- measures to divert flowing surface water

- a sketch of the operation showing relation to surface water

- an operational plan to ensure compliance with the permit requirements.

The basis for evaluation of an NPDES application by EPA staff includes adherence to EPA specific effluent guidelines; state water quality standards for the specific body of surface water; and water quality certification performed by the state (see below). 
After the requirements and conditions for granting the permit have been developed, a 30-day public notice is given during which any objections to the granting of the permit must be made. Substantial objections could result in a public hearing.

\section{Approximate Processing Time Required}

Approximate time to process the permit application is 3 to 6 months provided the application is submitted 180 days prior to construction.

\section{Permit or Regulation: Public Water Supply \\ Statutory Authority: Section 39-118, Idaho Code \\ Agency: Idaho Department of Health and Welfare (IDHW)}

The Idaho Department of Health and Welfare (IDHW) requires that plans and specifications for the construction of any new, modified, or expanded drinking water system must be approved by the Division of Environmental Quality (DEQ). This includes piping that delivers water for consumption by 10 or more premises, or 25 or more people for at least 60 days a year, or other systems designated by the director or having a public health significance. Developers of smaller water systems should contact their local District Health Department.

Plans and specifications submitted to the IDHW must be prepared and certified by a professional engineer licensed to practice in Idaho. When the construction is complete, certified as-built plans must also be submitted to the IDHW. In lieu of as-built plans, the engineer of record may certify that the facility was constructed according to the approved plans. For this requirement, the engineer of record must be hired to inspect the project while it is being constructed. If the engineer is not hired, or is released from the job, the engineer is required to inform DEQ.

The purpose of engineering reviews is to ensure that public health and water quality are protected by using accepted construction practices and materials.

\section{Approximate Time Required for Processing}

Water quality engineers make every reasonable effort to complete reviews as promptly as possible, generally within 30 to 45 days. Reviews are scheduled on a first come-first served basis.

\section{Permit or Regulation: Water Appropriation}

Statutory Authority: Sections 42-202 through 222, Idaho Code

Agency: Idaho Department of Water Resources (IDWR)

A water right allows use of a certain amount of ground or surface water for a specified use during a definite time period. The permit sets a priority or time of the title-holder's first application for water. A water right for power purposes according to Idaho law (Chapter 42-202 of the Idaho Code) can be initiated only by filing an application for a permit to divert or use ground or surface water. 
A properly filled out application form submitted with a required fee starts the water right permit process. IDWR supplies application forms and assistance in completing the form. The fee required varies with the rate of flow requested. Cerrain project details and costs and a financial statement from the applicant may also be required.

IDWR will then advertise the application as a legal notice. The legal notice will be published for 2 consecutive weeks in a local newspaper to notify residents of the possible increased use of water. People believe that a new appropriation of water may injure their prior water rights or other interests, they may file a protest with IDWR within 10 days of the last date of publication of the legal notice.

IDWR always attempts to resolve the differences between parties by means of an informal conference. If the issues cannot be resolved during the conference, IDWR may take testimony in a formal hearing format. In that case, information as required by rule 4,5,3 of IDWR's rules and regulations for water appropriation must be submitted.

Five criteria, as specified in Section 42-203 of the Idaho Code, must be evaluated by the director of the IDWR before making a decision on any application. The five criteria are:

1. the quantity of water available under existing water rights will not be reduced

2. the water supply is sufficient for the purpose for which it is being appropriated

3. application is made in good faith and not for delay or speculative purposes

4. an applicant has sufficient financial resources with which to complete proposed work

5. a project will not conflict with the local public interest (the local public interest is defined as the "affairs of the people in the area directly affected by the proposed use").

An application for a permit may be approved, approved with conditions, or denied. The director's decision may be appealed to the district court by any dissatisfied party.

A permit is issued for a maximum development period of 5 years with the possibility of a 5 year extension to complete a project. If delayed by legal action, it is possible to get additional extensions. When the project is completed, the permit-holder must file proof of beneficial use along with the required examination fee. IDWR will then inspect the use of the water and issue a license.

In order to protect groundwater resources from over exploitation, Idaho law allows for two area designations that limit groundwater appropriation within a designated area. These are:

(A) "Critical groundwater area" is defined as any groundwater basin or designated part thereof, not having sufficient groundwater to provide a reasonably safe supply for irrigation of cultivated lands, or other uses in the basin at the then current rates of withdrawal, or rates of withdrawal projected by consideration of valid and outstanding applications and permits (Idaho Code § 42-233a). 
If an application for permit is made in an area that has been designated as a critical groundwater area, the director of IDWR may deny the application if he believes that there is insufficient water available subject to appropriation at the location of the proposed well described in the application. This belief may come from the investigation of the application, or from investigation made in determining the area to be critical, or from other information that has officially come to his attention. If groundwater at the location is available in a lesser amount than that applied for, the director of IDWR may issue a permit for the use of the water to the extent that the water is available for appropriation.

(B) A "groundwater management area" is a groundwater basin that the director of the IDWR declares is approaching the condition of a critical groundwater area. The critical groundwater area designation may be used to justify denial of a groundwater permit for cogeneration development (Idaho Code $\$ 42-233 b$ ).

Application for permits made within a groundwater management area are approved by the director only after he has determined on an individual basis that sufficient water is available and that other prior water rights will not be injured.

Upon determination that the groundwater supply is insufficient to meet the demands of water rights within all or portions of a water management area, those water right holders will be ordered on a time priority basis, within the area determined by the director, to cease or reduce withdrawal of water until the director determines there is sufficient groundwater.

\section{Local Government Permits}

Within the framework of federal and state regulation, local governments perform duties which can have unique and significant impacts on energy project development. Local governments can set an example by financing and developing energy facilities themselves. They can encourage private development through information distribution and active recruiting of facilities. Cities and counties also regulate energy facilities. Below state-level citing thresholds, the jurisdictions are the primary development permitting authority. They set land use policy which controls the type and location of future development and affect construction techniques by enforcing building and electrical codes. They direct the division of lots through subdivision ordinances. They also regulate the type, mix, and location of land uses using zoning ordinances.

Zoning ordinances implement policies established in local land use plans and reduce land use conflicts by dictating the type of development allowed within the jurisdiction, the design of those uses, and the way potentially conflicting uses may coexist.

Policies and standards reflect both technical information and popular opinion. Local land use law often reflects values that are difficult to evaluate objectively. Public participation in a pro- 
ject approval may reveal concerns for property values, neighborhood quality, and scenic quality. Few local governments have done more with energy facility regulation than provide a forum for public involvement in siting decisions.

In some states, counties and incorporated cities prepare and adopt comprehensive land use plans which are acknowledged by a state-level commission. The plans indicate the location and significance of affected resources, and provide a regulatory framework for potential use. If a conflict is identified which is resolved against energy resource development, then another site must be found, unless the plan is amended. If the conflict is resolved in favor of energy resource development then, from a land use perspective, resource use is feasible. Development still may be subject to conditions which mitigate negative impacts. These requirements are described in the plan and local ordinances. Thus, developers can use comprehensive plans to learn what kind of projects might be feasible, and under what conditions.

Some counties discuss renewable resources in their comprehensive plans. However, discussion in the plans has often not led to zoning and ordinances. Frequently, adequate and up-to-date data on resources' location, quantity, and quality has not been given to local governments. Also, energy issues are not a priority in land use planning circles or most local governments.

In the absence of attention to the energy resource in the local land use plan, a prospective developer may have to champion a project proposal through the entire land use planning, zoning, and ordinance-writing processes. Such an effort would add many months to a project's lead time and increase its cost. Along the way, design changes are likely or the project may be found infeasible. The local government and public would be involved in broad planning, policy-making, and ordinance issues in the context of community reaction to a proposed project.

Local governments such as cities, counties, road districts, flood control districts, and drainage districts will have some jurisdiction over cogeneration development in nearly all cases. Most county governments in Idaho require building permits for construction and entail building code, electrical code, and plumbing code compliance. Most counties also have planning and zoning commissions that will review project plans for compliance with comprehensive plans, zoning regulations, and needs for conditional or special use permits. Counties may also have some jurisdiction over construction in or near defined flood plains and over use of, or construction near, county highways. The county courthouse, the county zoning administrator, and the county highway district are the best contacts for determining what permits or approvals will be required.

If a proposed site is within a city's limits or within its area-of-impact, appropriate contact should be made with city officials regarding building permits, zoning regulations, flood plain construction, and highway usage. Contact the city hall of the nearest city for a determination of the required permits and approvals and jurisdiction. 
Smaller communities often issue all permits through a single office, such as the Clerk's Office. In some counties, one or more highway districts exist that are responsible for construction and maintenance of roads. These agencies will be the administrators of all permits/approvals having to do with public rights-of-way.

A number of these permits, mainly those administered by the local planning departments, will involve substantial discretionary action on the part of the decision makers, approval being based on conformance of plans with established criteria or standards. Therefore, these decisions will usually be made by elected or appointed officials (city councilmen, county commissioners, or planning and zoning commissioners). Another group of approvals will be based on the adequacy of technical plans. These will generally be the permits listed as being administered by the public works department and building department. Several items will be simply a matter of registration, including the business license and registration of proprietorship. The following is a general description of each of the permits and approvals which may be required.

\section{Determining Which Permits are Required}

To enable a developer to determine what local permits are necessary for a particular site, and for guidance in obtaining local permits, the following guidelines are provided.

- Determine with certainty within what local jurisdiction the project site lies. Assumptions about jurisdiction are often inaccurate. Even if a site is within the county, it is possible it may be within a city's Area of Impact, which would give the city certain jurisdiction over the project.

- Contact agency staff early to obtain information about permits and to discuss your plans. Go into their office in person to make personal contact and to show your commitment to expediting the permitting process.

- Determine what permits will be required for the proposed project; what information should be provided; the process that will be followed; and time frames, including submittal dates, hearing dates, and the time within which a decision can be expected.

- Get copies of the applicable regulations so you can personally review them and the evaluation criteria. Ask questions if the written regulations vary from information the staff has provided.

- In the case of more discretionary permits, ask the staff about the likelihood of approval; also what might help to speed up the process and decision.

- Submit a complete application. Incomplete applications will result in processing delays. 
- Attend all meetings where the application will be discussed. If there is no one to respond to questions, delays may occur or the permit may be denied.

\section{Construction}

\section{Permit or Regulation: Approval of a Private Road} Agency: Local Planning and Zoning Department/Planning and Zoning Commission

Zoning ordinances often require public approval of a private road to ensure that adequate access will be provided to all parcels served by it and to evaluate its impact on the public street network. A plan of the proposed road showing dimensions, improvements, adjacent parcels, and land ownership generally serves as application. Approval may occur at the staff level after review, or may be granted after review by the Planning and Zoning Commission.

\section{Approximate Time Required for Processing}

Processing time will usually be a few days if approval can be made at the staff level, and may be several weeks if review by the Planning and Zoning Commission is required.

\section{Permit or Regulation: Approval of Public Road Plans Agency: Local Public Works Department}

Any street to be dedicated to the public for maintenance purposes must meet established standards for public streets, and be approved by the responsible authority for streets and roads. If accomplished as part of a subdivision, processing will be as specified for subdivisions. If undertaken as improvement to an existing street, plans are submitted to the street authority for review and approval.

Approximate Time Required for Processing

Processing can often be accomplished within several weeks.

\section{Permit or Regulation: Building Permit/Occupancy Agency: Local Building Department}

The issuance of a building permit is based on the compliance of proposed plans with the adopted building code. In some counties, the building permit may be administered by the Idaho Department of Labor and Industrial Services. The occupancy permit allows utilities to provide permanent service to the use. It is issued after on-site inspection confirms that construction has been carried out in conformance with plans. Notice of construction completion must be given to begin the inspection. 
Approximate Time Required for Processing

Timing for issuance of a occupancy permit will vary greatly depending on staff schedules, but can reasonably be expected to occur within 1 or 2 weeks of notification.

Timing for issuance of a building permit for an industrial use can be expected to be at least several weeks after submittal of building plans.

Permit or Regulation: County Road Access

Agency: Local Public Works Department; Local Highway District

Many counties require approval for a proposed driveway or private road that will access from a county road. To obtain approval, a drawing of the proposed driveway/road showing location of access and relation to intersections, hill, etc., will probably be required.

Approximate Time Required for Processing

Approval is generally by the staff and can be granted within 2 weeks of application submittal.

Permit or Regulation: Design Review Approval

Agency: Zocal Planning and Zoning Department

This process examines the functional logic and aesthetic impacts of proposed a r velopment plans, and is much more often a requirement of larger city governments than a county. A design review committee consisting ot design professionals and lay public often conducts such reviews.

Approximate Time iequired for Processing

Processing time may be as littlie as 2 weeks.

Permit or Regulation: Right-of-Way Encroachment

Agency: Local Public Works Department

Any work to be carried out within a public right-of-way requires a permit to interfere with the right-of-way. An application must state why such encroachment is necessary and the duration. In some cases, form.al permits are not issued, but notification of the road authority with jurisdiction is necessary.

Approximate Time Required for Processing

Approval is by the staff and should be granted within several weeks. 
Permit or Regulation: Sign

Agency: Local Planning and Zoning Department

A permit is often required for a sign to certify that it complies with adopted standards. Other permits required for larger or special types of signs are usually similar to Conditional Use Permits (CUP). Application for a sign permit is likely to require submittal of plans, including a scale drawing of the sign and a plan showing how and where it is to be located.

Approximate Time Required for Processing

Processing usually consists of staff review of the plans for conformance with ordinance requirements and may take as little as several days.

\section{Permit or Regulation: Utility}

Agency: Local Public Works Department

Installation of utility lines in a public right-of-way requires a utility permit. Plans must be submitted for staff review and approval.

Approximate Time Required for Processing

Processing may be accomplished within several weeks.

\section{Land Use}

\section{Permit or Regulation: Comprehensive Plan Amendment Agency: Planning and Zoning Commission}

Most cities and counties in the state have a comprehensive plan, establishing goals and policies for development. A project that will conflict with the goals and policies requires a change in the plan that will eliminate the conflict. Such an amendment is a major change in policy and thus requires public hearings and consideraible time (minimum about 3 months). The process normally requires a written proposal on how the plan should be amended, a public hearing by the Planning and Zoning Commission with a recommendation to the elected body, and a hearing by the elected body prior to a decision. Planning and Zoning Commissions are authorized by law to make such recommendations to the elected body only twice a year.

\section{Permit or Regulation: Floodplain Development Agency: Planning and Zoning Commission}

Where a project is proposed to be built near a body of water, a floodplain permit is often required. The major issue is usually the effect of the project on flooding conditions and on other 
properties. Application is made through submittal of topographic maps showing the location of the proposed development. Generally a public hearing will be held by the Planning and Zoning Commission, who will decide whether to issue the permit.

Approximate Time Required for Processing

Normal processing time is about 30 days but may vary greatly.

\section{Permit or Regulation: Rezoning Agency: Planning and Zoning Commission}

Most cities and counties in the state have established zoning within their boundaries. Each zone has land uses permitted either outright or by special permit. If the proposed energy project is not among uses permitted in the designated zone, the zoning must be changed to permit it at that site. A standard form is usually completed for the application. The hearing and approval process is essentially the same as for a Comprehensive Plan Amendment.

\section{Permit or Regulation: Special/Conditional Use Agency: Planning and Zoning Commission}

Land uses that are only permitted within the zone by special or conditional use permit must be considered in a public hearing by the Planning and Zoning Commission or the elected body. Their consideration is to address whether the proposed use is appropriate in the particular location, taking into account surrounding land uses, condition of streets, and other site factors. Conditions on the design and operation of the proposed use can be established in the permit. Application usually requires submittal of a standard form and plans for the proposed project.

Approximate Time Required for Processing

Minimum time to secure a permit is normally about a month to month and a half.

\section{Permit or Regulation: Variance}

Agency: Local Board of Appeals/Planning and Zoning Commission

Within each zone, standards are established regarding the location of structures on the property. If, for some reason involving unusual property conditions, compliance with the standards is impractical, a variance may be granted. Application usually requires a map showing the subject property, its unusual conditions, and surrounding property. A local Board of Appeals may hold the public hearing to consider the application and approve or deny the request. If a local Board of Appeals does not exist, the procedure is usually similar to that for a rezoning, with the Planning and Zoning Commission recommending to the elected body, who must approve or deny the variance. 
Approximate Time Required for Processing

Minimum time for processing is about a month, though it will depend on the process of the particular jurisdiction.

\section{Permit or Regulation: Zoning Certificate}

Agency: Local Planning and Zoning Department

A zoning certificate is issued to ensure that a project to be constructed is allowed in the particular zone. It will be required to obtain a building permit. If the zoning is proper for the proposed use, the certificate can often be issued immediately by the staff. Information required usually pertains to the proposed location and use.

\section{Safety/Health}

Permit or Regulation: Discharge to the Public Sewer System

Agency: Local Public Works Department

In order to discharge project effluent into a public sewer system, a permit is required by most municipalities/sewer districts. Information about the character and amount of effluent and times of discharge must be supplied in the application. While evaluation and approval will normally occur at the staff level, the matter may be presented to the elected body prior to issuance of a permit for its concurrence.

Approximate Time Required for Processing

Timing on the permit may be several weeks to a month.

\section{Other Permits}

Permit or Regulation: Registration of Sole/General Proprietorship Agency: County Recorder

The County Recorder is responsible for registering all sole general proprietorship business. 


\section{Permit Summary Sheet MONTANA}

Thermal Thermal Trans-

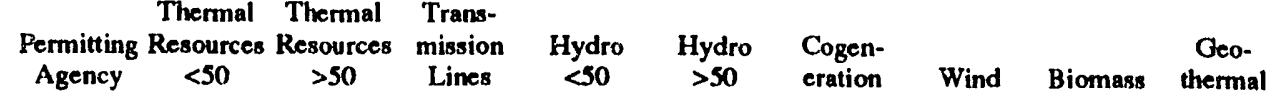

\section{MAJOR FACILITY SITING/ENVIRONMENTAL \\ IMPACI}

Montana Major l'acility Siting Act Certificale Montana Environmental Policy Act

AIR QUALITY

Air Quality Permit

WATER QUALITY/WATER USE

Water Pollution Discharge Permit

Beneficial Water Use Permit

Streambed/Streambank Alteration

Hydroelectric Power Development on

State Lands (easement)

Hydroelectric Power Development at

State-Owned Dams (eascments)

LAND USE

Soil and Water Conservation District

Land Use Regulations

Floodplains and Floodway Permits

Heritage Sites Permits

Natural Areas (Land use limitations)

State-Owned Lands (permits, leases,

easements)

Local Zoning and Land Use Regulations

\section{CONSTRUCTION}

Highway Encroachments (Easements)

Overhead Lines

Highway Utility (Easements)

Lakeshore Work Protection (Permits)

Public Water Supply (License)

Sewer Sysiem Approval

Building Codes/Permits

Mechanical, Electrical, and Plumbing

Permits

\section{FOREST AREAS}

Timber Removal/Slash Disposal

\section{SAFETY/HEALTH}

Dam Safety Construction/Operation Permits

Solid Waste Disposal (License)

Hazardous Waste Disposal (Permit)

\section{OTHER}

FERC Certification

Cogeneration and Small Power

Production Facilities Certification

\section{FISH/WILDLIFE}

Fish and Wildlife Impact Evaluation Need

$\begin{array}{lll}\underset{\text { Varies }}{\text { MDNRC }} & \bullet & + \\ \text { MDHES } & \dagger & + \\ \text { MDHES } & \text { o } & \bullet \\ \text { MDNRC } & \dagger & \dagger \\ \text { LA } & * & x\end{array}$

MDSL

MDSL

$\begin{array}{cc}\text { I.A } & * \\ \text { MDNRC,LA } & * \\ \text { MSHPO } & * \\ \text { MDSL,MDFWP } & * \\ \text { MDSL } & * \\ \text { LA } & *\end{array}$

MDT

LA

LA

MDHES

LA

LA,MDC

LA,MDC

MDSL

MDNRC

MDHES

MDHES

FERC

PSC

MDFWP

\section{+
$x$
+
+
+}

- $x$

- $\quad x$

\section{Agencles Kej}

Varies Lead agency varies by project

LA Local agencies

MDNRC Montana Dept. of Natural Resources and Conservation

MDHES Montana Dept. of Health and Environmental Sciences

MDSL Montana Department of State Lands

MSHPO Montana State Historic Preservation Office

MDT Montana Department of Transportation

MDC Montana Department of Commerce

MDFWP Montana Department of Fish, Wildlife, and Parks

$\dagger=$ Permit required

- $\quad$ Permit may be required

$x=$ Included in Montana Major Pacility Siting Act review. The Siting Act supersedes other state and local permitting requirements not related to air and water quality or occupational safety, but applicants are strongly urged to work with local agencies to make sure their concerns are met.

* $\quad=$ Site specific

$+=$ Transmission lines greater than $115 \mathrm{kV}$ are covered by the Major Facility Siting Act. For these lines the Siting Act overrides other related to air and water quality or occupational permits not safety. Transmission lines greater than $69 \mathrm{kV}$ but not greater than $115 \mathrm{kV}$ are exempt from the Act if they meet certain landowner approval requirements. Transmission lines $69 \mathrm{kV}$ or smaller are not covered by the Act. Lines of $230 \mathrm{kV}$ or less and 10 miles or less in length are also exempt from the Act. 


\section{Chapter 3 The Montana State Process}

The chapter is organized into three sections: 1) State Agency Responsibilities; 2) State Cogeneration Permits, Licenses, and Approvals; and 3) Local Permits.

Important cogeneration and solid waste terms and acronyms can be found in the glossary. A list of each agency involved in regulating cogeneration development with a brief description of its responsibilities can be found on pages 71 through 78 . The state agencies are listed in alphabetical order for ease in finding them and not in order of importance to the cogeneration developer. For the addresses and telephone numbers of these agencies are in Appendix $C$.

Cogeneration permits, licenses, and approval section on pages 78 through 96 are described in brief. Local permits are listed on pages 99 through 105 . Both the state and local sections serve only as a short summary of the requirements. The descriptions are intended only to introduce the reader to the regulations and corresponding institutions that affect cogeneration development. For more detailed information, consult the Montana Code Annotated (MCA) and the Administrative Rules of Montana (A.R.M). The MCA is available at most large public libraries and college and university libraries while the A.R.M. is available at most college and university libraries. Copies of specific rules are usually available from the agency that administers them. The Montana State Library in Helena is a good source for all state documents and reports cited in this section.

Developers are cautioned that the information described herein may only be a starting point on the road to obtaining all the needed approvals. It is not a substitute for working closely with authorized agencies and other professionals to assure a project that is in compliance with all state laws and rules.

The regulations, agencies, and policies are subject to change. Changes may occur when energy or a project becomes a political issue; the state legislature meets; a preexisting popular land use is thought threatened; elected and appointed officials change; and/or new directions are imposed on state and local government by the federal government. Accordingly, developers should verify and continuously monitor the laws and status of laws that might affect their plans.

The time required for obtaining all permits, licenses and/or approvals may be a substantial part of the total project duration. Therefore, it is important for the cogeneration developer to contact the state agencies to initiate the permitting process in the early stages of project development. 


\section{State Regulatory Agencies}

There are approximately ten state agencies involved in regulating biomass-fueled cogeneration development to some extent. The primary state agencies are the Montana Department of Health and Environmental Sciences, the Montana Department of Natural Resources and Conservation, and the Montana Public Service Commission. Other state agencies that may require permits or otherwise act in a review capacity include the Montana Department of Agriculture; the Montana Department of Commerce; the Montana Department of Fish, Wildlife, and Parks; the Montana Department of Labor and Industry; the Montana Department of State Lands; the Montana Department of Transportation; and the Montana State Historic Preservation Office.

The institutions that enforce the regulations and issue the necessary permits establish the forums where a project can be organized, changed, delayed, or stopped. By consulting with appropriate agency officials during the preliminary design and analysis phase, potential problems with a particular site or design can be identified. Appropriate modification can then be made, thus avoiding last-minute delays.

The following are the state agencies involved in regulating cogeneration development.

\section{Agency: Montana Department of Agriculture (MDA) \\ Statute: MCA 80-4-601 et seq.; MCA 80-9-201; ARM 4-12-201 et seq.; MCA 80-4-501 et seq.}

Any person who engages in a business involving or, as a part of his business, participates in buying, exchanging, negotiating, or soliciting the sale, resale, exchange, or transfer of any agricultural commodity in the state of Montana is a commodity dealer and must obtain a license from the Montana Department of Agriculture (MDA) before engaging in business in Montana.

The term, commodity dealer, does not apply to: 1) a person engaged in storing, shipping, or handling agricultural commodities for hire; 2 ) a person who buys agricultural commodities from a licenses commodity dealer or who does not purchase more than $\$ 30,000$ worth of agricultural commodities from producers during a licensed year; 3 ) a person who is the producer of agricultural commodities that he actually plants, nurtures, and harvests; or 4) a person whose trading in agricultural commodities in limited to trading in commodity futures on a recognized futures exchange.

Any person who wants to engage in the business of a commodity dealer must apply for a license to the MDA on forms provided by the department. The application must include the name of the applicant, the location of the principal places of business, a sufficient and valid bond, the number and description of trucks used to transport agricultural commodities, a financial statement, and any other information requested by the department. A license is issued annually and may be renewed by submitting all required licensing documents. 


\section{Agency: Montana Department of Commerce (MDC)}

Statutory Authority: 2-15-1801, MCA

The Montana Department of Commerce (MDC) is the state's lead economic development agency, providing technical and financial assistance to businesses, as well as state planning for economic development.

It has several offices that can provide cogeneration development assistance. The International Trade Office, the Census and Economic Information Center, and the Small Business Development Center, which works in conjunction with the federal Small Business Administration, are located in the Business Development Division. The Board of Investments manages state funds and issues loans frum the state Coal Severance Tax Trust Fund. The Science and Technology Alliance manages a capital financing program that provides seed money, supports research and development projects, and in general works with venture capital. The Building Codes Bureau is located in the department, as are the different professional and occupational licensing boards, such as for architects and engineers.

The Business Licensing Center of the MDC has a toll free number which is included in Appendix C. The center also produces the free publication, the Montana Business Licensing Handbook, which offers a brief summary of many of the business licenses and permits required by the state.

The MDC is also responsible for tourism, local government assistance, consumer affairs, low interest housing loans, and Indian affairs.

\section{Agency: Montana Department of Fish, Wildlife, and Parks (MDFWP); Montana Fish and Game Commission Statutory Authority: 2-15-3401, MCA}

The Montana Department of Fish, Wildlife, and Parks (MDFWP) is responsible for managing Montana's wildlife, state recreation lands, and state parks. Its policy is set by the Montana Fish and Game Commission and controls many types of land. Its authority over state lands exists under a number of arrangements, including patent, deed, lease, easement, agreement, or withdrawal.

The MDFWP participates with other state and local agencies to obtain instream water reservations for fish and wildlife, and reviews and permits projects under the Stream Preservation Act.

The MDFWP reports and advises state agencies on the impacts or potential impacts of major energy facilities and/or energy-related activities on fish and wildlife resources. It also participates in the state's review of proposed new hydroelectric projects. 


\section{Agency: Montana Department of Health and Environmental Sciences (MDHES); Board of Health and Environmental Sciences (BHES) Statutory Authority: 2-15-2101, MCA}

The Montana Department of Health and Environmental Sciences (MDHES) is responsible for protecting and improving the air, land, and water quality. It is responsible for administering the Montana Clean Air Act, and implementing clean air programs and plans mandated by the Federal Clean Air Act; enforcing odor control rules; administering the Montana Water Quality Act and the Montana Pollutant Discharge Elimination System Permit Program (MPDES); controlling how radioactive substances are handled in the state; operating solid and hazardous wastes programs; and regulating occupational noise and indoor emissions in workplaces.

The Board of Health and Environmental Sciences (BHES), which is administratively attached to the MDHES has authority to evaluate need, environmental impacts, and effects on public health, safety, and welfare for energy facilities.

The 1977 Federal Clean Air Act Amendments required classification of the areas of the state according to whether they meet the National Ambient Air Quality Standards (NAAQS). The MDHES classified each area into one of three categories including attainment, which is meeting the standards; nonattainment, which is exceeding the allowable limits for pollutants; or unclassified, which is insufficient information to determine the status. The areas which were designated nonattainment were required to develop state implementation plans to control emissions and bring the areas into compliance. Detailed information on classification requirements and attainment and nonattainment areas is available from the MDHES, Air Quality Bureau. Biomass projects locating in nonattainment areas may be required to meet more stringent air pollution emission rates depending on the existing air quality in the locale where the project is to be sited.

The MDHES is also responsible for enforcement of odor control rules. A person operating any business or using any machine, equipment, device, facility, or process which discharges into the outdoor air any odorous matter or vapors, gases, dusts, or combination thereof which create odors is subject to regulation. That person is required to provide, properly install, and maintain in good working order and operation, odor control devices or procedures as specified by the MDHES.

MDHES administers the Montana Water Quality Act and the Montana Pollutant Discharge Elimination System Pernnit Program (MPDES). The MPDES permit contains water quality limitations and requires self-monitoring of effluent by the permittee. The MPDES permit contains water quality limitations and requires self-monitoring of effluent by the permittee.

Problems may occur if leachate is produced when rain or other water passes through solid waste. The leachate can pick up various mineral, organic, or other contaminants, and then can contaminate surface or groundwater. Point source discharges of pollutants into state waters are regulated 
by the Montana Water Quality Act and require either a Montana Pollutant Discharge Elimination Sysiem (MPDES) Permit or a Montana Groundwater Pollution Control System (MGPCS) Permit (see Water Quality, pages 94 and 95).

The Montana Hazardous Waste Act (MCA 75-10-401 et seq.) and the corresponding rules (A.R.M. 16.44.101 et seq.) were adopted to administer and enforce a hazardous waste program pursuant to the federal Resource Conservation and Recovery Act of 1976. The MDHES regulates the permitting and siting of hazardous waste management facilities. MDHES also has detailed reporting and monitoring requirements with which these facilities have to comply.

Anyone who generates or transports hazardous wastes is required to register with the MDHES, Solid and Hazardous Waste Bureau and obtain an identification number. A generator is required to pay a sliding-scale fee based on the amount of waste generated annually, and to renew registration annually. Beginning in September 1986, anyone who produces 100 kilograms (approximately 220 pounds) or more of hazardous wastes per month will be required to register and comply with all reporting and transporting rules. Detailed reporting rules require both generators to fill out manifest forms with the source, amount, and destination of the wastes. The transporter, as well as the receiving hazardous waste management facility, must sign and date the manifest to acknowledge receipt of the waste shipinent. This process helps the generator ascertain that the waste has reached its destination at a properly licensed hazardous waste disposal site. The MDHES has established procedures for dealing with problems that occur in the transportation and reporting process.

The MDHES may, by rule, prescribe conditions under which specified hazardous wastes or specified quantities of hazardous wastes may be disposed of at solid waste disposal sites licensed by MDHES.

The hazardous waste rules also include regulations related to leaking underground storage tanks. These tanks include, but are not limited to, any one combination of tanks used to contain a regulated substance, the volume of which is 10 percent or more beneath the surface of the ground, and also include any underground pipes used to contain or transport a regulated substance and connected to a storage tank, whether the storage tank is entirely above ground, partially above ground, or entirely underground. If an owner or an operator of an underground storage tank discovers or is provided evidence that the tank may have leaked, the MDHES must be immediately notified that a leak may exist.

Energy producers are responsible for determining if any of their waste products or streams are hazardous wastes. They are also responsible for properly collecting, storing, and recovering or transporting the hazardous waste to a licensed disposal site. The Environmental Protection Agency (EPA) has identified a number of hazardous wastes (40 CFR 261.1-26.33) which must be kept under control from their origin to their point of disposal.

Cogeneration facilities have the potential to generate hazardous wastes or waste streams that contain hazardous constituents, especially when they are not operating under ideal conditions. 
For instance, a municipal solid waste combustor which is not operating under ideal conditions can produce hydrocarbons and creosote from incomplete combustion. These toxic substances should be captured by pollution control equipment, or as ash from the incinerator, and may need to be handled and disposed of as hazardous wastes. Under certain operating conditions, developing biomass energy technologies such as gasification, liquefaction, and pyrolysis, have the potential to produce wood tar containing creosote, benzopyrene, and phenol. Plants that produce hazardous wastes either under normal operating conditions or less than ideal operating conditions must register with MDHES as hazardous waste generators. They must present MDHES with a plan for proper collecting, handling, storing, and transporting the hazardous waste to a licensed disposal site or must obtain a permit as a hazardous waste management facility.

Commercial products used in energy production such as acids, bases, and solvents can be classified as hazardous wastes when they are discarded, spilled, leaked, or are left as residue in discarded drums. Energy products such as methanol, butanol, hydrocarbons, and diesel fuel substitutes can, if spilled, be classified as hazardous wastes because they are combustible.

Energy producers that use or produce commercial products that can be classified as hazardous wastes when discharged should register as hazardous waste generators with MDHES, Solid and Hazardous Waste Bureau, and make arrangements for proper disposal of those wastes at a licensed disposal site. The registration and planning will decrease the possibility of being cited for spilling or improper handling of hazardous waste. Acid and base effluent streams will not be subject to hazardous waste control if they are properly handled and neutralized under carefully controlled conditions.

The MDHES, Occupational Health Bureau, has the authority to regulate occupational noise and indoor emissions in workplaces that are under the jurisdiction of state and local governments. MDHES does not require or issue permits, but has established standards in these two areas. In the A.R.M. 16.42.101, MDHES establishes maximum noise exposure le vels that represent conditions that nearly all workers may be repeatedly exposed to without adverse effect on the ability to hear and understand normal speech. The MDHES establishes maximum threshold limit values for air contaminants that nearly all workers may be exposed to day after day without adverse effects.

\section{Agency: Montana Department of Labor and Industry (MDL\&I) Statutory Authority: 2-15-1701, MCA}

The Montana Department of Labor and Industry (MDL\&I) administers the state's industrial safety laws, holds contractor bonds, serves as an employment agency, collects and disburses state unemployment funds, provides for apprenticeships, and oversees federal Job 'Training Partnership Act (JTPA) grants. In addition, it enforces state wage and hour laws, hears disputes on state employee relations, unemployment insurance, and Workers' Compensation, and enforces state and federal antidiscrimination in employment laws. 
The Safety Bureau inspects all boilers installed and operated in Montana. Strict rules must be followed for safe construction, installation, operation, inspection, and repair of equipment.

\section{Agency: Montana Department of Natural Resources and Conservation (MDNRC); Board of Natural Resources and Conservation (BNRC); Board of Oil and Gas Conservation (BOGC)}

Statutory Authority: 2-15-3301, MCA

The Montana Department of Natural Resources and Conservation (MDNRC) executes statutory responsibilities concerning the state's land, water, and energy resources. It administers a wide range of state and federal programs dealing with renewable energy and energy conservation. It is responsible for preparing environmental impact statements (EIS) for projects that fall under Montana's Major Facility Siting Act and the Montana Environmental Policy Act.

The Energy Facility Siting Council is located within the MDNRC. The Concil reviews proposals to construct and operate facilities for generating, converting, or transmitting energy in Montana. Montana has given the Council limited powers over state and private lands. Authority for the construction of cogeneration facilities is handled by the Board of Natural Resources and Conservation (BNRC) under the Major Facility Siting Act.

The BNRC, which is administratively attached to the department, has authority to approve reservations of water under the Montana Water Use Act. Also, under the Major Facility Siting Aci the BNRC must certify public need for and environmental compatibility of energy facilities before construction begins. After a certificate has been issued, BNRC and other agencies have ongoing responsibility to monitor certified facilities for compliance with certificate conditions and with air and waster quality permits.

Any person who wants to appropriate surface or groundwater must apply to the MDNRC, Water Rights Bureau for a Beneficial Water Use permit. Beneficial uses include agricultural, domestic, fish and wildlife, industrial, irrigation, mining, municipal, power generation, and recreational uses. Every person, including but not limited to an individual, partnership, association, public or private corporation, city or municipality, county, state agency, or state of Montana, and federal agency of the United States of America, on its own behalf or as a trustee for an Indian or Indian tribe asserting a claim for an existing use of water, must file for a certificate of water rights. For more information on water rights, contact any of the MDNRC, Water Rights Bureau Field Offices listed in Appendix C.

In addition, the Board of Oil and Gas Conservation (BOGC), also administratively attached to the MDNRC administers laws regulating the drilling and recovery of Montana's oil and gas resources. 


\section{Agency: Montana Department of State Lands (MDSL) Statutory Authority: 2-15-3201, MCA}

The Montana Department of State Lands (MDSL) has four basic functions including management of the lands held by the state of Montana in trust for the support of the common schools and other institutions; regulation of mining conducted on private, state, and federal lands; fire prevention and suppression on certain private, state, and federal lands; and regulation of and assistance to private forest iand owners.

Requirements regarding harvesting of timber and removal of slash and wood waste for commercial uses vary depending on land ownership. The Boards of County Commissioners (BCC); the DSL, Forestry Division; the United States Department of Agriculture, Forest Service (USFS); and the United States Department of Interior, Bureau of Land Management (BLM) all administer forest lands in Montana.

A permit is required from MDSL for slash disposal, timber cutting, or timber stand improvements on private lands, state lands, or right-of-way clearing by public or private utilities. Permits may be issued to county residents to use dead or inferior timber for fuel or domestic purposes. Farmers, ranchers, and prospectors may also obtain permits for timber removal on state forest land in quantities not to exceed 25,000 board feet for domestic purposes in the repair and development of the farm or ranch. Permits may be issued to Montana citizens for commercial purposes at commercial rates without advertising for timber in state forests in quantities of less than 100,000 board feet or in emergency cases due to fire, insects, or blowdown (see Forest Areas, page 88.) For more information, contact the MDSL or any of its field offices at the ad-dresses listed in Appendix C.

Timber sales on federal lands administered by the BLM and the USFS are advertised for competitive bids. The BLM may negotiate individually with purchasers for small amounts of timber in special instances. For more information, contact each National Forest or each office of the BLM at the addresses in Appendix A.

The Lands Division has jurisdiction over rivers, lakes, and streams designated as navigable waters in Montana and maintains a current list of navigable waters in state. If there will be activity on a river, lake, or stream from low-water mark to low-water mark, consult MDSL for permitting and other requirements.

\section{Agency: Montana Department of Transportation (MDT) Statutory Authority: 2-15-2501, MCA}

The Montana Department of Transportation (MDT) regulates various aspects of transportation and activities adjacent to highways. Permits are required for special fuels; restricted routes or loads; temporary trips; over-sized vehicles; outdoor advertising; highway right-of-way, encroachments, and approaches; and utility mains. 
The Highways Division constructs, maintains, and protects the state highway and bridge system. It also grants right-of-way easements for utilities and property access. In addition, it manages the state motor pool and the roadside rest areas, and enforces the state Outdoor Advertising Control Act.

The Rail and Transit Division is responsible for public transportation coordination and rate analysis and litigation.

The Motor Transport Services Division enforces commercial vehicle weight and dimension laws, licensing, permitting, and fee collection on motor transport fuel taxes.

\section{Agency: Montana Public Service Commission (MPSC) Statutory Authority: 69-1-102, MCA}

Montana's Public Service Commission (MPSC) is a five-member elected body with the responsibility to ensure that public utilities provide adequate service to customers at reasonable rates. It approves investor-owned utility rates, including those for Qualifying Facilities (QF), but has limited authority over municipal utilities's rate increases. Its jurisdiction generally includes private natural gas, electric, telephone, and water companies doing business in the state.

The MPSC approves rules the competitive bidding process for the acquisition of new electric resources by the investor owned utilities (IOUs).

In addition, the MPSC regulates intrastate railroads and certain motor carriers. Also, it oversees natural gas pipeline safety regulations.

\section{Agency: Montana State Historic Preservation Office (MSHPO) Statutory Authority: 2-15-1512, MCA}

The Montana State Historic Preservation Office (MSHPO) is responsible for cooperating with and advising other state agencies when potentially valuable historical, archaeological, or other cultural resources are located in a project area (Montana Antiquities Act and the National Historical Preservation Act). Part of the advice given to other agencies may include comments on an applicant's plan for impact mitigation of sites eligible for nomination to the National Register of Historic Places. The MSHPO is also responsible for issuing antiquities permits for projects on state lands.

\section{State Cogeneration Permits and Licenses}

Although a number of permits, etc., are listed, cogeneration facilities may only require a few. The permits, licenses, and/or approvals are categorized alphabetically under type. Specific time 
requirements are found at the end of each description. For more information on these permits, contact the corresponding agency. Addresses and telephone numbers for these state agencies can be found in Appendix 1C.

\section{Air Quality}

Permit or Regulation: Air Quality Permit

Statutory Authority: Montana Clean Air Act, 75-2-101 et seq., MCA

Agency: Montana Department of Health and Environmental Sciences (MDHES)

A permit from the Montana Department of Health and Environmental Sciences (MDHES), Air Quality Bureau, is required for the construction, installation, and operation of equipment or facilities that may directly or indirectly cause or contribute to air pollution. Exceptions include sources that emit less than specified amounts (e.g., ventilating systems, motor vehicles).

A permit to construct or operate a new or altered air pollution source cannot be issued unless the source is able to comply with the ambient air quality standards, emission limitations, and other rules adopted under the Montana Clean Air Act and the applicable regulations and requirements of the Federal Clean Air Act (see Table 3 for Montana and National Air Quality Standarcás.) A city or county may administer its own air pollution permit program in lieu of the MDHES permit program. The Environmental Protection Agency (EPA) has jurisdiction over Indian reservations, except for incorporated municipalities on those reservations (see Appendix 1F).

\section{Table 3}

\section{Some Air Pollutants Regulated by the State of Montana*}

Asbestos

Benzene

Carbon Monoxide $\left(\mathrm{CO}_{2}\right)$

Fluorides

Hydrogen Sulfide $\left(\mathrm{H}_{2} \mathrm{~S}\right)$

Nitrogen Oxides

Ozone

Particulate Matter

Sulfur Dioxide

Sulfur-Reduced Sulfur Compounds (including $\mathrm{H}_{2} \mathrm{~S}$ )
Sulfur-Total Reduced Sulfur (including $\mathrm{H}_{2} \mathrm{~S}$ )

Sulfuric Acid Mist

Trace Metals

Beryllium

Lead

Mercury

Phosphors

Vinyl Chloride

*Sourcz: A.R.M. 16.8.921, page 16-179; 40 CFR Part 60 and 61 
Energy facilities that emit any air pollutants should calculate the potential emissions at maximum design capacity after the application of best available control technology (BACT). A permit is required from the MDHES, Air Quality Bureau for projects which have the potential to emit more than 25 tons per year of any pollutant except lead, in which case a permit is required at 5 tons a year. Some air pollutants regulated by Montana are listed in Table 4. This list of pollutants may be subject to change as new rules are developed.

\section{Table 4}

\section{Montana and National Air Quality Standards}

\begin{tabular}{|c|c|c|c|c|}
\hline \multicolumn{3}{|r|}{ Montana Standard } & $\begin{array}{c}\text { Federal } \\
\text { Primary Standard }\end{array}$ & $\begin{array}{c}\text { Federal } \\
\text { Secondary Standard }\end{array}$ \\
\hline \multicolumn{2}{|c|}{$\begin{array}{l}\text { Total Suspended } \\
\text { Particulates }\end{array}$} & $00 \mathrm{ug} / \mathrm{m}^{3} \mathrm{z}^{3}$ 24-hr average & $\begin{array}{r}75 \mathrm{ug} / \mathrm{m}^{3} \text { annual } \\
\text { geometric mean }\end{array}$ & $\begin{array}{l}60 \mathrm{ug} / \mathrm{m}^{3} \text { annual } \\
\text { geometric mean } \\
150 \mathrm{ug} / \mathrm{m}^{3} \text { 24-hr average* }\end{array}$ \\
\hline \multicolumn{2}{|c|}{ Sulfur Dioxide } & $\begin{array}{l}02 \mathrm{ppm} \text { annual average } \\
10 \mathrm{ppm} 24 \text {-hr average } \\
50 \mathrm{ppm} 1-\mathrm{hr} \text { average }\end{array}$ & $\begin{array}{l}0.03 \mathrm{ppm} \text { annual average } \\
0.14 \mathrm{ppm} 24-\mathrm{hr} \text { average* }\end{array}$ & $0.5 \mathrm{ppm} 3-\mathrm{hr}$ average* \\
\hline \multicolumn{2}{|c|}{ Carbon Monoxide } & $\begin{array}{l}\text { ppm 8-hr average* } \\
\text { ppm hourly average* }\end{array}$ & $\begin{array}{l}9 \mathrm{ppm} 8 \text { 8-hr average* } \\
35 \mathrm{ppm} \mathrm{1-hr} \mathrm{average*}\end{array}$ & 9 ppm 8-hr average* \\
\hline \multicolumn{2}{|c|}{ Nitrogen Dioxide } & $05 \mathrm{ppm}$ annual average & $0.05 \mathrm{Fpm}$ annual average & $0.05 \mathrm{ppm}$ annual average \\
\hline \multicolumn{3}{|c|}{$\begin{array}{l}\text { Photochemical } \\
\text { Oxidants (ozone) }\end{array}$} & $0.12 \mathrm{ppm} 1-\mathrm{hr}$ average* & $0.12 \mathrm{ppm} 1-\mathrm{hr}$ average* \\
\hline \multicolumn{3}{|c|}{ Lead $1.5 \mathrm{ug} / \mathrm{m}^{3} 90$-day average $\quad 1.5 \mathrm{ug} / \mathrm{m}^{3}$ calendar } & $\begin{array}{l}\text { None } \\
\text { quarter average }\end{array}$ & \\
\hline \multicolumn{2}{|c|}{ Foliar Fluoride } & $\begin{array}{l}\mathrm{ug} / \mathrm{g} \text { grazing season } \\
\mathrm{ug} / \mathrm{g} \text { monthly average }\end{array}$ & None & None \\
\hline \multicolumn{2}{|c|}{ Hydrogen Sulfide } & 05 ppm hr average* & None & None \\
\hline \multicolumn{2}{|c|}{$\begin{array}{l}\text { Settled Particulate } \\
\text { (Dustfall) }\end{array}$} & $\mathrm{gm} / \mathrm{m}^{2} 30$-day average & None & None \\
\hline \multicolumn{2}{|c|}{ Visibility } & $\begin{array}{l}\text { rticle scattering } \\
\text { coefficient of } 3 \times 10^{-5} \\
\text { per meter annual aver }\end{array}$ & None & None \\
\hline \multicolumn{4}{|c|}{$\begin{array}{ll}\mathrm{ug} / \mathrm{m}^{3} & =\text { micrograms pollutant per cubic meter of sampled air } \\
\mathrm{ppm} & =\text { parts pollutant per millio parts of sampled air } \\
* & \text { Not to be exceeded more than once per year. } \\
\text { ** } & \text { Not to be exceeded more than } 18 \text { times per year. } \\
\text { *** } & \text { Applies to PSD mandatory Class I areas. }\end{array}$} & \\
\hline
\end{tabular}




\section{Permit: Open Burning Permit}

Statute: MCA 76-13-121 and 7-33-2205 ARM 26.6.301-304 and 16.8.1301 et seq.

Agency: Montana Department of Health and Environmental Science (MDHES)

Any person, agency, institution, business, or industry conducting any open burning is required to have an air quality open burning permit. Open burning means combustion of any material directly in the open air without a receptacle, or in a receptacle other than a fumace, multiplechambered incinerator, or wood waste burner. Any major open burning source is one which will emit more than 500 tons per calendar year of carbon monoxide or 50 tons per calendar year of any other pollutant regulated by the Montana Department of Health and Environmental Science (MDHES) except hydrocarbons. A minor open burning source refers to any open burning which is not major open burning. A minor open burning source need not obtain a permit, but must comply with all rules and regulations and special buming periods as stated in the rules. The department requires use of best available control technology (BACT) for all open burning. BACT for open burning may include but not be limited to scheduling burning during periods and seasons of good ventilation, applying dispersion forecasts, limiting the amount of burning during any one time period, and promoting alternative treatments and uses of materials to be bumed. Materials which may not be disposed of by open burning are specified in the rules. The recognized protection agency for the area (county, state, or U.S. Forest Service) may also require a burning permit or may have special requirements or established time periods for burning. Exceptions are small recreational fires, construction site heating devices used to warm workers, and safety flares used to dispose of dangerous gases at refineries, gas sweetening plants, or oil or gas wells.

Prior to major open burning, an application must be submitted on forms provided by the MDHES. The application must contain a legal description or a detailed map of each planned site of open buming, the elevation of each planned site, the method of burning to be used and tik average fuel loading or total fuel loading at each site to be bumed. Permits are issued for one year. Conditional air quality open buming permits may be issued on a temporary basis for special categories of open buming of wood and wood by-product trade waste and untreated wood waste at licensed landfill sites which meet specific requirements stated in the rules. Emergency open burning permits may be issued to allow burning of a substance not otherwise approved for burning if the applicant demonstrates that the substance poses an immediate threat to public health and safety, or plant and animal life, and that no alternative method of disposal is available.

\section{Permit or Regulation: Prevention of Significant Deterioration (PSD) Permit Statutory Authority: Montana Clean Air Act, 75-2-102, et seq, MCA Agency: Board of Health and Environmental Sciences (BHES)}

Prevention of Significant Deterioration (PSD) standards apply when a major new source of air pollution is proposed in an area that has an ambient air quality better than the applicable standards. Review may include 1 year of preapplication baseline data, control technology review, air pollution impact modeling, and other appropriate measures. 
One may apply to the Board of Health and Environmental Sciences (BHES) for an exemption from applicable rules governing emissions. Such a variance may be issued if the BHES finds there will be no adverse impact on public health or safety, and that compliance with the rules would be an undue hardship on the applicant.

Class I areas, which allow small increases in pollution, include national parks, some wilderness areas, and some Indian reservations. Class I areas are listed in Table 8. The rest of Montana is designated Class II for air quality purposes.

Table 5

Montana PSD Class I Areas

Glacier National Park

Cabinet Mountain Wilderness

Flathead Indian Reservation

Mission Mountain Wildemess

Bob Marshall Wilderness

Scapegoat Wilderness

Selway Bitterroot Wilderness

Anaconda-Pinter Wilderness

Gates of the Mountains Wilderness
Red Rock Lakes National Wildlife

Refuge

Yellowstone National Park

U L Bend Wilderness Area

Northern Cheyenne Indian

Reservation

Medicine Lake National Wildlife

Refuge

Fort Peck Indian Reservation

*Source: Montana Air Quality Data \& Information Summary for 1984, Helena, MT, Montana Department of Health and Environmental Sciences, Air Quality Bureau, 1985.

Approximate Time to Obtain Permit.

There is a $\mathbf{3 0}$ day review period to ascertain if application is complete and accurate, followed by a 60 day review period for the permit. If there are environmental impact statement concems, this process could take considerably longer.

\section{Construction}

Permit or Regulation: Building Permit

Statutory Authority: 50-60-101 et seq., MCA

Agency: Building Codes Bureau, Montana Department of Commerce (MDC)

All construction throughout the state must comply with the state building codes and permit regulations. If towns or counties adopt local building codes, enforcement is by local rather than state authorities. A permit must be obtained from appropriate authorities before construction can begin. 
Approximate Time to Obtain Permit

Varies by town and/or county.

Permit or Regulation: Highway Encroachments and Easements

Statutory Authority: 7-14-2139, MCA

Agency: Montana Department of Transportation (MDT)

Permits are issued by the Montana Department of Transportation (MDT) for construction or maintenance of encroachments on or under highway rights-of-way. Encroachments include all private structures, devices, and facilities placed upon, over, or under the right-of-way. These include ditches, dikes, flumes, canals, or bridges and water, sewer, electric, natural gas, and communications lines. Written permission is required from the Board of County Commissioners (BCC) for any excavation or construction across county highways. Permission for easements and encroachments on or across state highway rights-of-way may be obtained from the MDT.

Approximate Time to Obtain Permit

It generally takes 2 weeks to obtain this permission.

Permit or Regulation: Highway Utilities Easements

Statutory Authority: 7-13-2101, 4101, MCA

Agency: Montana Department of Transportation (MDT)

Utility facilities used to transport or distribute hydrocarbons, electric power, energy/communication signals, water, and sewage are authorized to occupy highway rights-of-way if they conform to certain standards as approved by the Department of Transportation (MDT). City councils and boards of county commissioners grant similar approval along city streets and county roads.

Approximate Time to Obtain Permit

It generally takes 2 weeks to obtain this approval.

Permit or Regulation: Mechanical, Electrical, and Plumbing Permits

Statutory Authority: 50-60-101 et seq., MCA (Mechanical) 50-60-602 et seq., MCA (Electrical) 50-60-501 et seq., MCA (Plumbing)

Agency: Montana Department of Commerce (MDC); Building Codes Bureau

A mechanical permit is required for the design, construction, installation, quality of materials, location, operation, and maintenance of: heating, ventilating, cooling, or refrigeration systems; incinerators; and other miscellaneous heat producing appliances.

An electrical permit is required for any electrical installation in any new construction or remodeling. 
A plumbing permit is required for the installation, removal, alteration, or repair of plumbing and drainage systems.

The local building department may administer an enforcement program in lieu of the state program.

Approximate Time to Obtain Permits

Each permit can be obtained in about 2 days time.

Pernit or Regulation: Public Water Supply License

Statutory Authority: 75-6-101 et seq., MCA

Agency: Montana Department of Health and Environmental Sciences (MDHES)

A water system serving 10 or more families or 25 or more persons for 60 days out of the calendar year must be approved by the Montana Department of Health and Environmental Sciences (MDHES). Plans and specifications for public water supply wells must be approved, as well as plans for construction, alteration, or extensions of any water system or treatment facilities. Operators in charge of public water systems and treatment facilities must be licensed by the MDHES.

Permit or Regulation: Sewer System (Approval)

Statute: 75-6-101 et seq., MCA

Agency: Water Quality Bureau, Montana Department of Health and Environmental Sciences (MDHES)

Approval from the Water Quality Bureau, Montana Department of Health and Environmental Sciences (MDHES), is required to construct, alter, or extend a public sewer system serving 10 or more families, or 25 or more persons for at least 60 days out of the calendar year. Operators in charge of public sewer systems must be licensed by MDHES.

\section{Energy Facility Certification}

\section{Permit or Regulation: Certification as a Cogeneration or Small Power Production Qualifying Facility (QF)}

Statutory Authority: Cogeneration and Small Power Production Facilities, 69-3-601, MCA

Agency: Montana Public Service Commission (MPSC) and Federal Energy Regulatory Commission (FERC)

A cogeneration or small power production facility may be certified as a qualifying facility (QF). To be a qualifying facility, a facility must meet certain requirements as stated in Montana law:

- produce electricity by the use, as a primary energy source, of biomass, waste, water, wind, or other renewable resource or any combination of those sources 
- $\quad$ produce electricity and use-ful forms of thermal energy, such as heat or steam, used for industrial, commercial, heating, or cooling purposes through the sequential use of energy known as cogeneration

- have a power production capacity that together with any other facilities located at the same site is not greater than $80 \mathrm{MW}$

- be owned by a person not primarily engaged in the generation or sale of electricity other than electric power from a small power production facility.

The Federal Energy Regulatory Commission (FERC) controls the certification process for a qualifying facility. Facilities that are connecting to a utility can get interface guidelines from that utility. The Public Service Commission (MPSC) determines rates and conditions of those rates for contracts between small power producers and the utilities under MPSC's jurisdiction.

\section{Facility Siting/Environmental Impact}

\section{Permit or Regulation: Certificate of Public Need and Environmental Compatibility Statutory Authority: Major Facility Siting Act, 75-20-101 et seq., MCA Agency: Montana Department of Natural Resources and Conservation (MDNRC), Board of Natural Resources and Conservation (BNRC); Montana Department of Health and Environmental Sciences (MDHES); and the Board of Health and Environmental Sciences (BHES)}

The Montana Major Facility Siting Act provides for comprehensive review of proposals to construct and operate certain kinds of facilities for generating, converting, or transmitting energy in Montana. To minimize the impacts of such facilities, the Board of Natural Resources and Conservation (BNRC) must certify public need for and environmental compatibility of such facilities before construction begins.

The Montana Major Facility Siting Act applies to:

- facilities that can generate $50 \mathrm{MW}$ or more of electricity

- facilities that can use, refine, or convert 500,00J tons of coal or more per year

- electric transmission lines and associated facilities of more than 69 kilovolts $(\mathrm{kV})$, except:

a. lines of $230 \mathrm{kV}$ or less and 10 miles or less in length

b. lines of more than $69 \mathrm{kV}$ and up to and including $115 \mathrm{kV}$ for which the person planning to construct the line has obtained right-of-way agreements or options for a right-of-way from more than 75 percent of the owners who collectively own more than 75 percent of the property along the centerline

- facilities for developing and using cogeneration resources capable of producing 25 million Btu per hour or more.

Facilities such as transportation links, aqueducts, diversion dams, and transmission substations associated with the production or delivery of energy are included. Federally-owned or controlled facilities located on federal lands must satisfy the substantive criteria of the Major Facility Siting Act. 
Certification is required from the Montana Department of Health and Environmental Sciences (MDNRC) to ensure that the facility will not violate air and water quality standards or other laws administered by MDNRC. Both MDNRC and the Montana Department of Health and Environmental Sciences (MDHES) must accept an application as complete before the evaluation process can begin. Application must be made on forms supplied by the departments.

Applications for facilities filed under the Major Facility Siting Act must include a description of the proposed facility, with discussion of altemative sites, an explanation of need for a utility facility, and a filing fee, based on the estimated construction cost of the facility, to finance the state's evaluation.

The MDNRC and the MDHES may not accept an application unless the facility is identified in a long-range plan submitted to MDNRC at least 2 years before the application is filed.

A certificate may not be granted unless the BNRC finds and determines:

- the basis of the need for the facility

- the nature of the probable environmental impacts

- that the facility represents the minimum adverse environmental impact, considering the state of available technology and the economics of various alternatives

- that the facility is consistent with regional plans for expanding utility grids and will serve system economy and reliability

- that the facility's proposed location conforms to state and local laws and regulations

- that the Board of Health and Environmental Sciences (BHES) has certified that the facility will not violate air and water quality standards and implementation plans

- for a utility application, that the facility serves the public interest, convenience, and necessity.

Need, environmental impacts, benefits to the applicant and the state, effects of resulting economic activity, and effects on public health, safety, and welfare must be considered in making these determinations.

After a certificate has been issued, BNRC, MDNRC, BHES, and MDHES all have ongoing responsibility to monitor certified facilities for compliance with certificate conditions and with air and water quality permits. Certificates may be revoked for failure to meet safety standards or failure to comply with any other conditions imposed by BNRC.

An important element of the Major Facility Siting Act is its general applicability over other state laws. This authority means that if BNRC issues a certificate, no other state or local permit for construction or operation is required, except for air and water quality permits. In addition, such laws protecting employees are not superseded by this Act.

\section{Approximate Time Required for Processing}

Submission of an application to MDNRC and MDHES triggers a 90-day period in which the agencies must notify the applicant of any deficiencies. An acceptable application results in a study and evaluation by both departments. 
MDHES has 1 year for study and the MDHES or the BHES has an additional 6 months to decide if air and water quality permits should be issued.

MDNRC has 22 months from the date it accepts the application to complete its study and prepare a report including recommendations to the BNRC. The time limit for MDNRC's review and report for transmission lines under 30 miles long is 1 year.

The BNRC must schedule a hearing within 120 days of receiving the MDNRC's report. The applicant, the departments, affected municipalities, residents, and interested individuals and organizations may participate.

The entire hearing process, from the date of the MDNRC's report to the BNRC until the hearing examiner's report is filed, may not exceed 9 months unless the BNRC extends the time for good cause. The BNRC must make its decision within 60 days after the hearing examiner's report is submitted.

Permit or Regulation: Environmental Impact Statement (EIS) Approval Statutory Authority: Montana Environmental Policy Act, 75-1-101 et seq., MCA Agency: Varies by Project

Before any major action significantly affecting the quality of the environment is taken, a state agency must prepare an environmental impact statement discussing the environmental impacts of the proposed action. The requirement applies to issuance of state permits, licenses, and approvals for private actions that will have significant environmental impacts. When a single project requires permits from two or more agencies, a lead agency will be designated to collect the EIS fee and to coordinate preparation of the document.

Copies of the EIS and the comments and views of the appropriate state, federal, and local agencies that are authorized to develop and enforce environmental stardards must be made available to the Govemor, the Environmental Quality Council, and the public and must accompany the proposal through the existing agency review processes. Aiternatives to the proposal, irretrievable commitments of resources, and the relaiionship between short-term uses of the environment and long-term productivity must be discussed in the environmental impact statement.

An agency may prepare a preliminary environmental review (PER) to determine whether an environmental impact statement is necessary. If the need for an EIS is clear, the PER step may be bypassed. If the PER indicates no potential significant environmental impact, an EIS need not be prepared and the agency may proceed with the proposed action.

\section{Approximate Time to Obtain Environmental Impact Statement Approval}

If an environmental impact statement is necessary, the agency must prepare a draft environmental impact statement that is circulated to other agencies and to the public for comment. At 
least 30 days are allowed for comment with the possibility of a 30 day extension. A public hearing may be held after publication of the draft environmental impact statement. The agency is required to hold a hearing if a certain level of citizen interest is demonstrated.

A final environmental impact statenent will be prepared if necessary, incorporating responses to comments on the draft and comments received at the hearing if one was held. Final action on a permit inay not be taken sooner than 45 days after publication of the draft environmental impact statement nor sooner than 15 days after publication of the final environmental impact statement.

\section{Forest Areas}

Permit or Regulation: Slash Disposal/Timber Cutting Permit

Statutory Authority: 76-13-401 through 413, MCA

Agency: Montana Department of State Lands (MDSL)

A permit is required from the Montana Department of State Lands (MDSL), Forestry Division, for slash disposal, timber cutting, or timber stand improvements on private lands or right-of-way by public or private utilities.

\section{Approximate Time to Obtain Permit}

If it is done by mail, it will take approximately 2 weeks. The permit may be obtained immediately at a local MDSL office.

\section{Permit: Timber Removal Permit}

Statute: MCA 7-8-2608 through 2609, 77-5-211-213, ARM 26.6.401 et seq. Agency: Montana Department of State Lands (MDSL)

Permits for removal of dead or inferior timber from state forests are required by the DSL or Board of County Commissioners (BCC) for county forests. Permits may be issued on state or county forests to use dead or inferior timber for fuel or domestic purposes. Permits may also be issued to citizens of Montana for commercial purposes at commercial rates without advertising for timber on state or county forests in quantities of less than 100,000 board feet. Farmers, ranchers, and prospectors may also obtain permits to purchase timber on state forests in quantities not to exceed 25,000 board feet for domestic purposes in the repair and development of the farm, ranch, or mine. 


\section{Land Use}

Permit or Regulation: Easement on State School Trust Land

Statutory Authority: Title 77, Chapter 2, MCA

Agency: Board of Land Commissioners $(B L C)$ or Montana Department of State Lands (DSL)

The Montana Department of State Lands (MDSL) is involved in the permitting process for development if the proposed project is on state school trust land. The applicant is required to obtain an easement from the MDSL. Two types of easements are available: "Permanent Easements" require the approval of the Board of Land Commissioners (BLC). "Temporary construction permits" along or adjacent to permanent easements may be granted by license agreement with the MDSL. Another important factor is that the MDSL is required to obtain full market value for all easements on state lands. Thus, market value would have to be determined and sought.

Approximate Time to Obtain Permit

Applications requiring BLC's approval take about 2 or 3 months for approval.

Permit or Regulation: Floodplain and Floodways Permit

Statutory Authority: Floodplain and Floodway Management Act, 76-5-101 et seq., MCA Agency: Montana Department of Natural Resources and Conservation (MDNRC)

Artificial obstructions and nonconforming uses within a designated floodplain or floodway require a permit from the local governing body or from the Montana Department of Natural Resources and Conservation (MDNRC) if local authorities have not adopted rules. Local governments may adopt land use regulations, including floodplain management regulations within sheetflood areas, that may restrict development. If local regulations are not adopted, MDNRC must enforce minimum standards adopted by the Board of Natural Resources and Conservation (BNRC).

\section{Approximate Time to Obtain Permit}

It will take approximately 60 days to obtain this permit.

\section{Permit or Regulation: Heritage Site}

Statutory Authority: Montana Antiquities Act, 22-3-421 through 442, MCA

Agency: Montana State Historic Preservation Office (MSHPO) and

\section{Land Management Agencies}

State actions or state licenses, assisted, or permitted actions that have the potential to substantially alter heritage properties or paleontological remains on state-owned lands are regulated, as is excavation of heritage properties on state-owned lands.

In consultation with the Montana State Historic Preservation Office (MSHPO), the land management agency is required to determine wheth.r a proposed action may impact sites, structures, or 
objects on state-owned lands that qualify or would qualify as heritage properties. This may require completion of a systematic cultural resources inventory, recordation of a property likely to be harmed, consideration of alternative projects, special protective stipulations, project modifications, or denial of the project. Agencies may require applicants for permits or licenses to complete portions of this analysis.

Approximate Time to Obtain Permit or License

It will take 1 to 2 weeks to obtain this license.

\section{Permit or Regulation: Natural Areas (Land Use Limitations)}

Statutory Authority: 76-12-101 et seq., MCA

Agency: Board of Land Commissioners (BLC); Montana Department of State Lands (MDSL)

A natural area is one affected primarily by natural forces, with evidence of human activity at a minimum, and with outstanding natural features worthy of preservation. State-owned lands that are controlled or acquired by the Board of Land Commissioners (BLC) may be designated natural areas. Each area so designated is managed by a "managing entity" and will be subject to a master plan setting forth specific land use limitations and controls. If feasible, the state of Montana will hold the water and mineral rights in order to adequately protect the area.

\section{Permit or Regulation: State-Owned Lands (Permits, Leases, Easements)}

Statutory Authority: Title 77, Chapters 1-6, MCA

Agency: Montana Department of State Lands (MDSL); Montana Department of Fish, Wildlife, and Parks (MDFWP); Montana Department of Natural Resources and Conservation (MDNRC); and Other State Agencies

Activities on state-owned lands generally require permits, leases, or easements from the Montana Department of State Lands (MDSL) and approval from the Board of Land Commissioners (BLC). In addition, Montana Department of Fish, Wildlife, and Parks (NDFWP) and the Montana Department of Natural Resources and Conservation (MDNRC), and other state agencies should be contacted for information regarding rules and procedures on lands owned or administered by those agencies.

Approximate Time to Obtain Permit, Lease, and/or Easement

This varies by agency and property. 


\section{Safety/Health .}

\section{Permit or Regulation: Boiler License}

Statutory Authority: 50-74-101 et seq., MCA

Agency: Montana Department of Labor and Industry (MDL\&I)

All boilers must be licensed by the Montana Department of Labor and Industry (MDL\&I), Safety Bureau. In addition, all boilers installed and operated in Montana must follow the rules for safe construction, installation, operation, inspection, and repair of equipment as stated by the MDL\&I. The definitions and rules follow nationwide engineering standards as published by the American Society of Mechanical Engineers.

\section{Approximate Time to Obtain License}

To obtain a certificate of inspection, it will take approximately 2 weeks if there are no problems found. The boiler must then be reinspected on an annual basis.

\section{Permit or Regulation: Boiler Operator's License Agency: Montana Department of Labor and Industry (MDL\&I)}

Persons operating all boilers and steam engines covered by state law are required to hold the proper grade of license. To obtain a license a person must meet qualifications for licensing as detailed in the law and pass an examination. There are four classes of engineers including firstclass, second-class, third-class, and low-pressure engineers.

Exceptions to the minimum qualification requirement for all classes of engineers are:

- an applicant for an engineer's license in any classification who holds a valid license in that classification from another state having license requirements equal to or exceeding the minimum requirements set out in the law, who successfully passes a written examination prescribed by the division, and is found to be competent to operate a boiler and steam driven machinery in that classification shall be granted a license in that classification

- operating experience in a classification accumulated in the U.S. military services or the Merchant Marine service satisfactory to the division may be accepted in lieu of the operating experience required for licensing of engineers in each of the license classifications

- an applicant who has trained in the operation of steam or water boilers and steam machinery and has been certified as having satisfactorily completed a prescribed training course may be credited with a maximum of 6 months' experience toward a first-, second-, or third-class engineers license.

Each application submitted to MDL\&I for a hoiler operator's license must be accompanied by a payment of 50 percent of the license fee for that application. This payment is forfeited if the applicant fails to appear for or fails to pass the examination. An applicant must pass a written examination and meet other requirements as stated in the law. Licenses must be renewed annually. 
Permit or Regulation: Hazardous Waste Disposal Permit

Statutory Authority: Montana Hazardous Waste Act, 75-10-401 et seq., MCA

Agency: Montana Department of Health and Environmental Sciences (MDHES)

Waste is defined as hazardous waste if it is included in an EPA list of specific hazardous wastes, or demonstrates any of the characteristics of ignitability, corrosiveness, reactivity, or toxicity under standard test procedures. All hazardous wastes may only be transmitted, stored, treated, or disposed of in a manner consistent with state and federal law. A permit from the Montana Department of Health and Environmental Sciences (MDHES) is required to construct or operate a hazardous waste management facility. A preliminary environmental review is a necessary part of the hazardous waste facility review process.

If it is determined that an application for a certificate under the Major Facility Siting Act will result in the generation, transportation, storage, or disposal of hazardous wastes, MDHES must conduct its review concurrently with the studies of air and water quality conducted under the provisions of the Major Facility Siting Act.

Approximate Time to Obtain Permit

If application is complete and accurate, it could take from 4 months to 1 year to receive this permit.

Permit or Regulation: Solid Waste Disposal License

Statutory Authority: Solid Waste Management Act, 75-10-201 et seq., MCA Agency: Montana Department of Health and Environmental Sciences (MDHES)

A license is required from the Montana Department of Health and Envis onmental Sciences (MDHES) for disposal of solid waste and for the operation of a solid waste disposal facility. Sites are approved and licensed by MDHES and validated by local health officials. A preliminary environmental review is a necessary part of the solid waste application review process. Any person may apply to the Board of Health and Environmental Sciences (BHES) for a variance from the rules.

Approximate Time to Obtain License

If application is complete and accurate, it could take from 4 months to 1 year to receive this license. 


\title{
Water Quality/Water Use
}

\author{
Permit or Regulation: 310 Permit \\ Statutory Authority: Natural Streambed and Land Preservation Act, 75-7-101, et seq., MCA \\ Agency: Conservation Districts; U.S. Army Corps of Engineers (COE); \\ Montana Department of Fish, Wildlife, and Parks (MDFWP)
}

In applying for a 310 permit, the applicant must comply with the provisions set forth in the Natural Stream Bed and Land Preservation Act, which came into existence during the 1975 Legislative Session with the passage of Senate Bill 310. The purpose of this act is to protect and preserve the natural perennial-flowing rivers and streams and the land and property immediately adjacent to them, to prohibit unauthorized projects and protect the use of water for any useful or beneficial purpose as guaranteed by the constitution of the state of Montana. The Act applies to all private individuals and corporations on private, state, or federal land.

Any physical alteration of a natural perennial flowing stream, its beds, or immediate banks requires approval from either the Soil and Water Conservation District Supervisors, the Grass Conservation District Supervisors, or the Board of County Commissioners (BCC). In addition, a permit is required from the U.S. Army Corps of Engineers (COE) for any dredge and fill activity or other work affecting "navigable waters." This may include dredge or fill activity in wetlands.

Before engaging in any project that may obstruct or alter a stream, a state or local government agency must notify the Montana Department of Fish, Wildlife, and Parks (MDFWP). The MDFWP must notify the applicant whether the project will adversely affect fish or wildlife habitat. The MDFWP may require modifications to the project. If agreement cannot be reached, an arbitration panel may be appointed by the district court.

Approximate Time to Obtain Permit

Allow 60 days to obtain the 310 Permit.

\section{Permit or Regulation: Beneficial Water Use Permit}

Statutory Authority: Montana Water Use Act, 85-2-101 et seq., MCA

Agency: Montana Department of Natural Resources and Conservation (MDNRC)

A Water Use Permit must be obtained from the Montana Department of Natural Resources and Conservation (MDNRC) for all beneficial uses. Beneficial uses include, but are not limited to, agriculture, domestic use, fish and wildlife, mining, industrial activity, municipal supply, power generation, and recreation. However, if the project is located outside the boundary of a controlled groundwater area, a permit is not required before appropriating groundwater by means of a well or developed spring with a maximum appropriation of less than 100 gallons per minute. Notice of Completion of Groundwater Development Form No. 602 must be filed, however, to obtain a water right. 
If the developer has an existing water right or a permit, the law also requires a change authorization be obtained to change the place of use, purpose of use, place of storage, or point of diversion.

An Application for Beneficial Water Use Permit (Form No. 600), a Notice of Completion of Ground Water Development (Form No. 602), and an Application for Change of Appropriation Water Right (Form No. 606) may be obtained from the Water Resources Division, MDNRC, at the local county clerk and recorder's offices, or from any of the Water Rights Bureau offices located in Bozeman, Helena, Missoula, Kalispell, Havre, Glasgow, Lewistown, Miles City, or Billings.

\section{Approximate Time to Obtain Permit}

It is recommended that at least 6 months be allowed to process the permit or change of application request.

\section{Permit or Regulation: Montana Groundwater Pollution Control System Permit Statutory Authority: Montana Water Quality Act, 75-5-101 et seq., MCA Agency: Montana Department of Health and Environmental Sciences (MDHES)}

Any person who wants to discharge pollutants into state groundwaters must obtain an Montana Groundwater Pollution Control System (MGWPCS) permit. Groundwater classifications are established to protect water resources for beneficial uses. The Montana Department of Health and Environmental Sciences (MDHES) has a nondegradation policy for any groundwater whose existing quality is higher than established groundwater quality standards for its classification. That groundwater must be maintained at that high quality unless it has been positively demonstrated that a change is justifiable as a result of necessary economic or social development, and will not preclude present or anticipated uses of such waters.

Exclusions listed in the rules include, but are not limited to, solid waste management systems and hazardous waste management systems licensed by MDHES, discharges or activities regulated under the federal underground injection control (UIC) program, persons disposing of their own household waste on their own property, and agricultural irrigation projects.

All applications must be submitted on forms which are obtained from the department and must contain a site plan, location of treatment works and disposal system, list of people who own or lease adjacent land, location of adjacent state surface waters, location of water supply wells and springs within one mile, description of waste or process solutions, information on existing groundwater quality, and any additional information the department may require.

The applicant, any affected agency, the regional administrator of the Environmental Protection Agency (EPA), or any interested person may submit a written request for a hearing. A hearing will be held if the department determines good cause or sufficient interest exists to hold a hearing. 
The conditions of the permit will include proposed discharge limitations and conditions; monitoring and reporting requirements, if any; necessary schedules of compliance, including interim dates and requirements for meeting proposed discharge limitations; or other special conditions.

\section{Approximate Time to Obtain Permit}

An application for an MGWPCS Permit must be filed at least 180 days prior to beginning operation. The MDHES will determine if the application is complete within 30 days. Upon receipt of a completed application, the MDHES must make a tentative determination with respect to issuance or denial of a permit. The MDHES is then required to issue a public notice regarding the proposed discharge and the tentative determination. At least 30 days must be provided for a public comment period. The department will provide a 30-day public notice of the hearing. If a hearing is not held, the department must make a final determination within $\mathbf{3 0}$ days. If a public hearing is held, the MDHES must make a decision within 60 days following the hearing. A permittee must request reissuance of his permit at least 90 days prior to its date of expiration.

\section{Permit or Regulation: Montana Pollution Discharge Elimination System Permit (MPDES)}

Statutory Authority: Montana Water Quality Act, 75-5-101 et seq., MCA Agency: Montana Department of Health and Environmental Sciences (MDHES)

A permit from the Montana Department of Health and Environmental Sciences (MDHES) is required to construct, modify, or operate a disposal system or to construct or use any outlet for discharge of sewage, industrial wastes, or other wastes into state surface waters. The Montana Pollution Discharge Elimination System (MPDES) permit regulates the discharges of pollutants from point sources into state waters. A point source can be any discernible conveyance from which pollutants are discharged, such as a pipe, a ditch, or a floating craft. An animal confinement facility may also be a point source. All discharges of pollutants into state waters authorized by an MPDES permit must be consistent with the conditions of the permit. If there is a violation of the permit, the MDHES may modify, suspend, or revoke the permit. The MDHES has a nondegradation policy which requires that any state water whose quality is higher than the established water quality standards be maintained at that high quality. Permits may require effluent limitations or other conditions on industrial, public, or private projects or development that constitute a new or an increased source of pollution to high-quality waters.

Federal permitting authority is involved for activities on Indian reservations. For more information see National Pollutant Discharge Elimination System (NPDES) located in the Federal section of this guidebook, starting on page 13.

The application for an MPDES permit must be filed no less than 180 days prior to the operation of a point source. Application information required by MDHES includes but is not limited to plans and specifications, site descriptions, process and waste flow diagrams, and volume and nature of projected discharges. Upon receipt of a completed application, the MDHES must make a tentative determination with respect to issuance or denial of a permit. The MDHES is then re- 
quired to issue public notice and allow 30 days for public comment. If MDHES denies the discharge permit, a hearing may be requested. All permits are issued for a fixed term not to exceed 5 years.

\section{Discharge Waste Water on Indian Reservations}

Anyone who wants to discharge waste water on Indian reservations must obtain an National Pollutant Discharge Elimination System (NPDES) Permit - 33 U.S.C. 1251, 40 C.F.R. 122 et seq. from the Environmental Protection Agency (EPA) and comply with minimum discharge limits established by the EPA. A permit is also required to modify or expand a project. Incorporated municipalities' activities on Indian reservations are excluded.

\section{Approximate Time to Obtain Permit}

Any person who wants to discharge wastewater on an Indian reservation must apply to the EPA on forms provided by that agency. After a completed application has been received, EPA drafts either the permit or the denial, and publishes the notice of intent to issue or deny. There is a 30day comment period and then the agency must issue a denial or approval. EPA may include effluent limitations and monitoring and reporting requirements as conditions of the permit. A permit is issued for a fixed term up to 5 years. The applicant must apply for renewal of the permit 180 days before its expiration date.

\section{Permit or Regulation: Stream Protection Permit \\ Statutory Authority: 87-5-501, MCA}

Agency: Montana Department of Fish, Wildlife, and Parks (MDFWP)

A state or local government agency must obtain a permit before engaging in any project which may obstruct or alter a stream.

\section{Approximate Time to Obtain Permit}

Within 30 days after receipt of project plans, the Montana Department of Fish, Wildlife, and Parks (MDFWP) must notify the applicant whether the project will adversely affect fish or wildlife habitat. The MDFWP may require modifications in the project. If agreement cannot be reached, an arbitration panel may be appointed by the district court.

\section{Local Permits and Approvals}

Local governments often have jurisdiction over building and construction, land use, utilities, roads, and some environmental concerns such as air quality. Early in the development process a developer should contact local, city, and county planning and public works departments. These departments should be able to inform the developer of all local permits the project will require. 
Within the framework of federal and state regulation, local governments perform duties which can have unique and significant impacts on energy project development. Local governments can set an example by financing and developing energy facilities themselves. They can encourage private development through information distribution and active recruiting of facilities.

Below state-level citing thresholds, the jurisdictions are the primary development permitting authority. Local governments set land use policy and plan commercial, industrial, multi-family, and residential development locations.

Through zoning ordinances, the mix of development is controlled. Zoning ordinances implement policies established in local land use plans and reduce land use conflicts by dictating the type of development allowed within the jurisdiction, the design of those uses, and the way potentially conflicting uses may coexist.

Policies and standards reflect both technical information and popular opinion. Local land use law often reflects values that are difficult to evaluate objectively. Public participation in a project approval may reveal concerns for property values, neighborhood quality, and scenic quality. Subjective values are difficult to put into laws. Few local governments have done more with energy facility regulation than provide a forum for public involvement in siting decisions. Developers can use comprehensive plans to learn what kind of projects might be feasible, and under what conditions.

Some counties discuss renewable resources in their comprehensive plans. However, discussion in the plans has often not led to zoning and ordinances. Frequently, adequate and up-to-date data on resources' location, quantity, and quality has not been given to local governments. Also, energy issues are not a priority in land use planning circles or most local governments.

In the absence of attention to the energy resource in the local land use plan, a prospective developer may have to champion a project proposal through the entire land use planning, zoning, and ordinance-writing processes. Such an effort would add many months to a project's lead time and increase its cost. Along the way, design changes are likely or the project may be found infeasible. The local government and the public would be involved in broad planning, policymaking, and ordinance issues in the context of community reaction to a proposed project.

Local governments such as cities, counties, road districts, flood control districts, and drainage districts will have some jurisdiction over cogeneration development in nearly all cases. Most county governments in Montana require building permits for construction and entail building code, electrical code, and plumbing code compliance. Most counties also have planning and zoning commissions that will review project plans for compliance with comprehensive plans, zoning regulations, and needs for conditional or special use permits. Counties may also have some jurisdiction over construction in or near defined flood plains and over use of, or construction near, county highways. The county courthouse, the county zoning administrator, and the county highway district are the best contacts for determining what permits or approvals will be required. 
If a proposed site is within a city's limits or within its area-of-impact, appropriate contact should be made with city officials regarding building permits, zoning regulations, flood plain construction, and highway usage. Contact the city hall of the nearest city for a determination of the required permits and approvals and jurisdiction.

Smaller communities often issue all permits through a single office, such as the Clerk. In some counties, one or more highway districts exist that are responsible for construction and maintenance of roads. These agencies will be the administrators of all permits/approvals having to do with public rights-of-way.

A number of these permits, mainly those administered by the local planning department, will involve substantial discretionary action on the part of the decision makers, approval being based on conformance of plans with established criteria or standards. Therefore, these decisions will usually be made by elected or appointed officials (city councilmen, county commissioners, or planning and zoning commissioners). Another group of approvals will be based on the adequacy of technical plans. These will generally be the permits listed as being administered by the public works department and building department. Several items will be simply a matter of registration, including the business license and registration of proprietorship. The following is a general description of each of the permits and approvals which may be required.

\section{Determining Which Permits are Required}

To enable a developer to determine what local permits are necessary for a particular site, and for guidance in obtaining local permits, the following guidelines are provided.

- Determine with certainty within what local jurisdiction the project site lies. Assumptions about jurisdiction are often inaccurate. Even if a site is within the county, it is possible it may be within a city's Area of Impact, which would give the city certain jurisdiction over the project.

- Contact agency staff early to obtain information about permits and to discuss your plans. Go into their office in person to make personal contact and to show your commitment to expediting the permitting process.

- Determine what permits will be required for the proposed project; what information should be provided; the process that will be followed; and time frames, including submittal dates, hearing dates, and the time within which a decision can be expected.

- Get copies of the applicable regulations so you can personally review them and the evaluation criteria. Ask questions if the written regulations vary from information the staff has provided.

- In the case of more discretionary permits, ask the staff about the likelihood of approval; also what might help to speed up the process and decision. 
- Submit a complete application. Incomplete applications will result in processing delays.

- Attend all meetings where the application will be discussed. If there is no one to respond to questions, delays may occur or the permit may be denied.

\section{Air Quality}

Permit or Regulation: City or County Air Quality Permit

Statutory Authority: Montana Clean Air Act, MCA 75-2-101 et seq. Agency: Local Air Pollution Control Agency

A city or county may administer its own air quality permit program in lieu of part or all the Montana Department of Health and Environmental Sciences (MDHES) permit program.

Cities and towns in Montana are classified according to the National Ambient Air Quality Standards (NAAQS). Nonattainment areas are those which exceed allowable limits for certain air pollutants. Energy projects locating in nonattainment areas may need to meet stricter requirements regarding emission rates depending on the particular problem pollutants and the current monitoring levels of those pollutants.

A municipality or county may establish a local air pollution control program if it is consistent with the state program and is approved by the Board of Health and Environmental Sciences. After approval, the municipality or county may administer the air pollution control program in its jurisdiction. A complete explanation of the requirements and restrictions involving local programs can be found in Montana law, MCS 75-2-301.

\section{Permit or Regulation: Open Burning Permit Agency: Local Air Pollution Control Agency}

On county lands, a burning permit may be required to ignite a fire in the open air without a receptacle or in a receptacle, other than a furnace, multiple-chambered incinerator, or wood waste burner. 


\section{Construction}

Permit or Regulation: Building Permit

Statutory Authority: 50-60-101 et seq., MCA

Agency: Local Building Department

All construction throughout the state must comply with the state building codes and permit regulations. If towns or counties adopt local building codes, enforcement is by local rather than state authorities. A permit must be obtained from appropriate authorities before construction can begin.

Permit or Regulation: Highway Encroachments Easements

Statutory Authority: 7-14-2139, MCA

Agency: Board of County Commissioners (BCC) and/or Montana Department of Transportation (MDT)

Written permission is required from the Board of County Commissioners $(\mathrm{BCC})$ for any excavation or construction across county roads. Highway encroachments include all private structures, devices, and facilities placed upon, over, or under a right-of-way. These include ditches, dikes, flumes, canals, or bridges, and water, sewer, electric, natural gas, and communications lines. Permission for easements and encroachments on or across state highway rights-of-way may be obtained from the Montana Department of Transportation (MDT).

\section{Permit or Regulation: Highway Utilities Easements}

Statutory Authority: 7-13-2101, 4101, MCA

Agency: City Council, Board of County Commissioners, or

Montana Department of Transportation (MDT)

Utility facilities used to transport or distribute hydrocarbons, electric power, energy communication signals, water, and sewage are authorized to occupy highway rights-of-way if they conform to certain standards as approved by the Montana Department of Transportation (MDT). City councils and boards of county commissioners grant similar approval along city streets and county roads.

Supplying electric power, natural gas, and water to a site is usually regulated on a local level. The city or town council or board of county commissioners must grant permission for construction of gas, water, sewer, and other mains within the city limits and for construction of utility mains and lines along city streets and county roads. City or town councils may permit extension of utility lines outside city limits. 


\section{Permit or Regulation: Lakeshore Protection Permit \\ Statutory Authority: 75-7-207 through 217, MCA \\ Agency: Relevant Local Agency}

If the local government has adopted lakeshore protection regulations, a permit is required for any work that will alter the current or cross-sectional area of a navigable lake or its shore. Such activities include constructing channels or ditches; dredging the lake bottom to remove muck, silt, or weeds; ponding; filling; and constructing breakwaters or wharves and docks. A variance from local regulations may be obtained if an impact statement is prepared and a public hearing held.

The proposed work must not: 1) materially diminish water quality; 2) materially diminish habitat for fish or wildlife; 3 ) interfere with navigation or other lawful recreation; 4) create a public nuisance; or 5) create a visual impact discordant with natural scenic values as determined by the local government, where such values form the predominant landscape elements.

If petitioned by 30 percent of the landowners with property abutting a lake, the Montana Department of Natural Resources and Conservation (MDNRC) may adopt and enforce regulations.

\section{Permit or Regulation: Mechanical, Electrical, and Plumbing Permits Statutory Authority: 50-60-101 et seq., MCA (Mechanical) \\ 50-60-602 et seq., MCA (Electrical) \\ 50-60-501 et seq., MCA (Plumbing) \\ Agency: Local Building Department}

Local building departments may assume jurisdiction over the building, mechanical, plumbing, or electrical permits required for construction projects. If a local building department administers their own program, they may also add to the standards enforced by the Montana Department of Commerce (MDC), extend their jurisdiction up to four and one-half miles outside the city limits, or establish their own fee schedule.

For those areas under county jurisdiction, building and electrical permits from the public works or building department are generally required. The project plans will be reviewed for compliance with Montana building and electrical code requirements. Operations on county roads may also require permits from the public works department.

A mechanical permit is required for the design, construction, installation, quality of materials, location, operation, and maintenance of: heating, ventilating, cooling, or refrigeration systems; incinerators; and other miscellaneous heat producing appliances.

An electrical permit is required for any electrical installation in any new construction or remodeling.

A plumbing permit is required for the installation, removal, alteration, or repair of plumbing and drainage systems or parts thereof. 
The local building department may administer an enforcement program in lieu of the state program.

\section{Permit or Regulation: Overhead Lines}

Statutory Authority: 69-4-401 et seq., 69-4-601, 602, 7-13-4106, MCA

Agency: Local Planning \& Zoning Department

The city or town council may regulate erection of poles and cables within city limits. Persons moving buildings, equipment, or other structures that will require moving overhead lines must give the person responsible for operating the lines 10 days notice.

Permit or Regulation: Sewer System (Approval)

Statutory Authority: 75-6-101 et seq., MCA

Agency: Local Public Works Department

Approval from local agencies is required to construct, alter, or extend a public sewer system. The applicant must disclose the quantity and type of sewage that will be discharged to make certain it does not overload the current treatment capacity. Operators in charge of public sewer systems must be licensed by their local agency.

\section{Fire Protection}

\section{Permit or Regulation: Fire Safety Inspections}

Statutory Authority: MCA 50-61-101, ARM 23.7.101 et seq.

Agency: Local Fire Authority

Buildings designed for assembly, business, education, industrial, institutional, or residential occupancy (other than single-family private homes) must meet fire escape, fire alarm, and fire extinguisher requirements. Industrial occupancy includes, but is not limited to, mills, power plants, and processing plants. Local fire authorities may have their own enforcement program, may require a permit, or may have adopted a fee schedule. Fire safety inspections may be conducted locally by the municipal fire chief or the county sheriff. Contact the local fire authority in your area.

\section{Forest Areas}

Permit or Regulation: Timber Removal Permit

Statutory Authority: MCA 7-8-2608 through 2609, 77-5-211-213, ARM 26.6.401 et seq.

Agency: Board of County Commissioners $(B C C)$

Permits for removal of dead or inferior timber from county forests are required by the Montana Department of State Lands (MDSL) or Board of County Commissioners (BCC). Permits may be 
issued on to use dead or inferior timber for fuel or domestic purposes. Permits may also be issued for commercial purposes at commercial rates without advertising for quantities of less than 100,000 board feet.

\section{Land Use}

Permit or Regulation: Local Zoning and Land Use Permit

Statutory Authority: Title 76, Chapter 2, MCA (Counties)

Title 76, Chapter 3, MCA (Municipalities)

Agency: Local Planning \& Zoning Department

Before commencing any development activity, a person should determine if local zoning regulations exist. Under Montana law, cities, towns, and counties may adopt zoning regulations and establish zoning districts for the regulation of height and size of buildings, percentage of lot occupied, size of yards, density of population, location, and use of buildings, etc. If zoning exists, a pernit for the development or activity may be required.

\section{Permit or Regulation: Soil and Water Conservation District Land Use Statutory Authority: 76-15-701 et seq., MCA Agency: Local Soil and Water Conservation Districts}

Lands located within a soil and water conservation district may be subject to land use regulations designed to conserve soil and water resources, and control erosion. Variances awarded upon demonstration of great practical difficulties or unnecessary hardship are allowed.

Types of activities regulated may include the following: engineering operations for dams, dikes, ponds, ditches, fences, and other construction.

\section{Solid Waste}

Permit or Regulation: Solid Waste Management System (Approval) Statutory Authority: 2-15-2101, MCA

Agency: Local Health Department

A Snlid Waste Management System License is required from the Montana Department of Health and Environmental Sciences (MDHES), Solid and Hazardous Waste Bureau to establish and operate a solid waste management disposal facility. Sites for these facilities must be approved and licensed by MDHES and validated by local health officials. Resource recovery systems that provide for the collection, separation, recycling, or recovery of solid wastes, including disposal of nonrecoverable waste residues are classified as solid waste management systems. 


\section{Permit Summary Sheet OREGON}

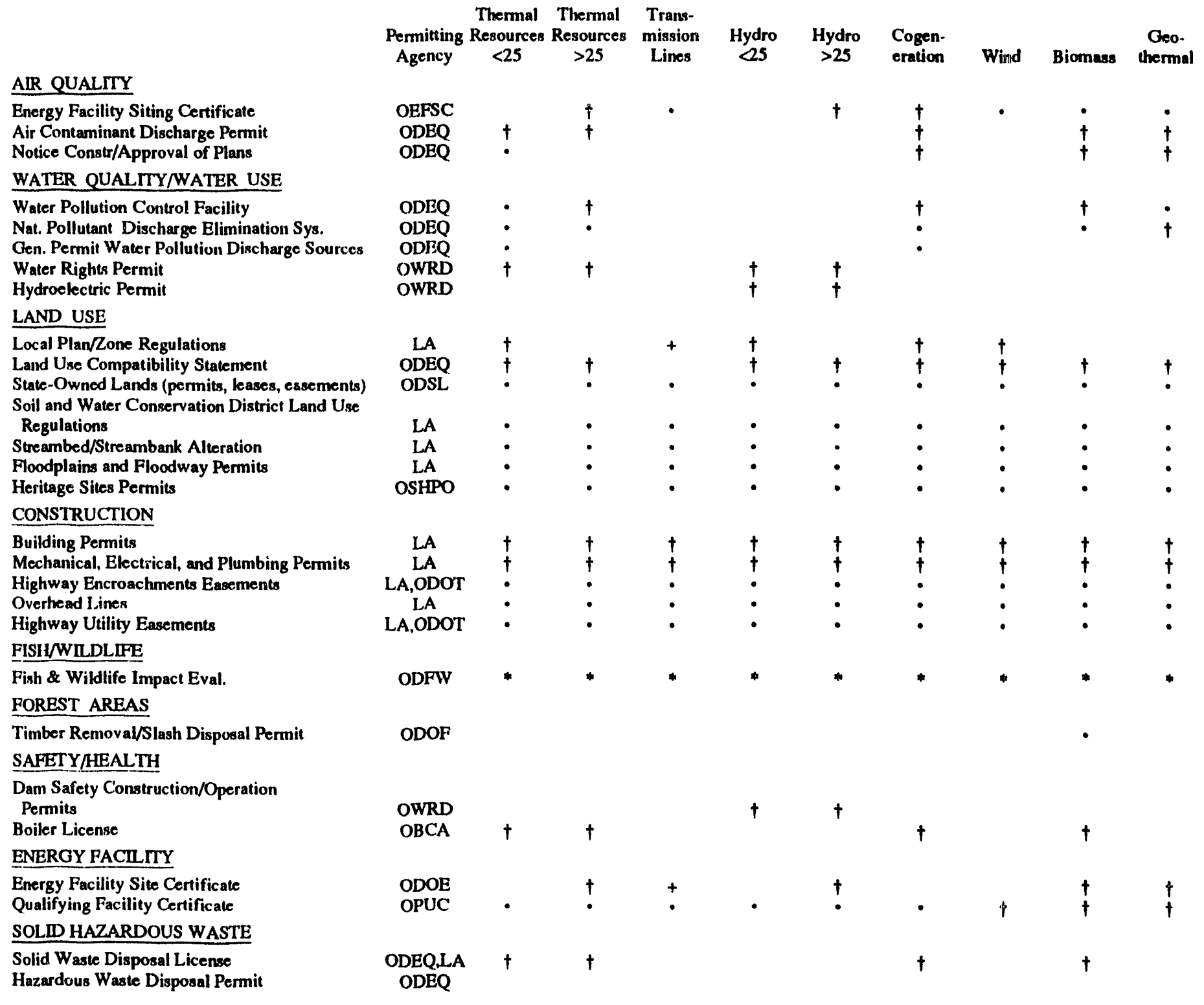

Agencles

LA

ODSL

OEFSC

ODFW

ODOE

ODOF

ODEQ

ODOT

OPUC

OWRD

OSHPO

OBCA
Local Agencies

Oregon Division of State Lands

Oregon Energy Facility Siting Council

Oregon Department of Fish and Wildlife

Oregon Department of Energy

Oregon Department of Forestry

Oregon Department of Environmental Quality

Oregon Department of Transportation

Oregon Public Utility Commission

Oregon Water Resources Department

Oregon State Historic Preservation Office

Oregon Building Codes Agency
Key

$\dagger=$ Permit required

- = Permit may be required

$x=$ Included in Energy Facility Site Certificnte review. The Siting Act supersedes other state and local permitting requirements, but applicants must get local agency upprovuls.

* = The agency provides comments on projects to other agencies processing permits.

$+=$ Transmission limes greater than $230 \mathrm{kV}$, plus longer than 10 miles, plus are located in more than 1 political subdivision must get a Site Certificate. Limen not meeting ell three criteria. 


\section{Chapter 4 \\ The Gregon State Process}

This chapter serves as a guide for understanding state and local requirements necessary to develop energy facilities in Oregon. It explains the permits and regulations which the state requires before construction begins. These requirements are concerned with a wide variety of issues such as construction, legal rights, public safety, environmental concerns and many may apply to other types of projects in addition to cogeneration development.

The time required for obtaining all permits, licenses and/or approvals may be a substantial part of the total project duration. Therefore, it is important for the cogeneration developer to initiate permitting in the early stages of project development. Specific time requirements may be found in the sections describing the individual permits.

Biomass is Oregon's second largest renewable energy resource. It provides approximately 25 percent of Oregon's energy, second only to hydroelectric power. In 1989, biomass supplied about 15 percent of residential space heat. Wood and pulping liquors supplied nearly 80 percent of industrial process steam.

\section{Oregon State Agencies' Responsibilities}

There are several state agencies involved in the regulation of energy facilities depending on size. Although numerous agencies have potential permitting or review authority, cogeneration facilities are likely to require only a few permits and/or licenses. Biomass fuels include wood, industrial and municipal solid waste, crop residues, manures, grain, or energy crops from forest plantations. These fuels are converted to energy through direct combristion, gasification, anaerobic digestion, and fermentation.

Oregon statutes (ORS 469.320 et seq.) provide for comprehensive review of proposals to construct and operate certain kinds of facilities for generating, converting, or transmitting energy in Oregon. Certification of $\boldsymbol{r}$ need for and environmental compatibility of these facilities is required before construction segins.

State policy encourages the development of permanently sustainable energy resources, including biomass. Oregon must also protect the environment from air and water pollutants. The state requires projects to obtain land use approval, environmental permits, and construction permits. 


\section{Agency: Oregon Department of Energy (ODOE)}

\section{Statute: ORS, Chapter 469}

Oregon Department of Energy (ODOE) was established to provide comprehensive state leadership on energy planning and forecasting, to support research on alternate sources of energy, to be a central repository for energy data and to educate the public about energy problems and conservation. Private or federal funds are used to support these activities.

The ODOE oversees three major programs, including Energy Conservation, Policy and Resource Planning, and Nuclear Safety and Energy Facilities. ODOE's Small Scale Energy Loan Program makes long-term, low-cost loans for projects that conserve or produce energy.

ODOE administers federal programs for energy conservation in schools, hospitals, public care, and local government buildings. It also provides staff support for the Oregon Energy Facility Siting Council (OEFSC) and the Energy Policy Review Committee. The director is responsible for supervising day-to-day functions of the department, supervising and facilitating work on siting as directed by the Energy Facility Siting Council, and adopting rules and issuing orders to carry out ORS Chap-ter 183 and the policy stated in ORS 269.010.

The director's office also is responsible for public information, writing and publishing a wide variety of handbooks and pamphlets for public distribution, maintaining film and publication lists, and arranging for public speaking engagements for department personnel.

ODOE is divided into four divisions. The Nuclear Safety Division staffs the OEFSC, discussed further in this guide. The Policy and Planning Division provides technical assistance to developers. The Conservation Services Division provides assistance to developers. The Business Energy Tax Credit Program provides a 35 percent tax credit for businesses that install energy conservation, renewable resource, and recycling projects.

\section{Agency: Oregon Energy Facility Siting Council (OEFSC) Statute: ORS, Chapter 469}

The Oregon Energy Facility Siting Council (OEFSC), established unjer provisions of the state Energy Facility Siting Act, claims jurisdiction over certain energy facilities on all lands, private, state, or federally owned. Site certifications are required by OEFSC for any biomass or cogeneration power plant with a nominal electrical generating capacity of more than 25 megawatts; pipelines transporting biomass or cogeneration fluids that are 6 inches or greater in diameter and 5 miles or longer in length; and high voltage transmission lines of more than 10 miles in length with a capacity in excess of 230,000 volts.*

\footnotetext{
*The United States Department of the Interior Bureau of Land Management does not, however, recognize OEFSC authority over federal lands, but will make every attempt to coordinate and cooperate with OEFSC on the siting of facilities within the state of Oregon (Mohorich, 1985).
} 
The OEFSC has adopted general standards that apply to all energy facilities and require the following mandatory findings:

- need for the proposed facility based on energy demand and economic prudence

- protection of public health and safety

- environmental protection

- beneficial use of wastes and byproducts

- conformance with statewide planning goals and comprehensive land-use plans

- protection of historical and archaeological sites

- no infringement on existing water rights

- necessary expertise to operate, construct, and retire the facility

- reasonable assurance of obtaining the necessary funds

- identification of foreseeable socioeconomic impacts in the vicinity of the proposed facility (OAR 345-74-025).

The OEFSC also has the power to conduct investigations into all aspects of site selection, to designate areas within the state as suitable or unsuitable for biomass or cogeneration power plants, and to establish standards and promulgate rules that must be satisfied in order to obtain a site certification.

A very important element of state energy facility siting statutes, and a critical role of the implementing authority, is to provide for the coordination of permits and license applications through all state and local agencies affected by such an application. Another important element is to ensure that the coordination with other agencies makes siting of all energy facilities a one-step process for applicants. This procedure saves both time and money, and ensures that all applications are handled and evaluated in a consistent manner. Once a siting certificate for a transmission or energy conversion facility is granted, all state and local agency permits and licenses must automatically be granted. Each permitting agency, however, retains the authority to enforce all requirements of the permit or license issued. Examples of some of the permits required include conditional land use permits, construction permits, drilling permits, a permit for the disposal of liquid wastes, and permits for air emissions.

\section{Agency: Oregon Public Utility Commission (OPUC)}

Statute: ORS, Chapters 757, 758

The Oregon Public Utility Commission (OPUC) regulates electrical and natural gas utilities, large water districts, telephone, and transportation industries. The OPUC must ensure that utilities provide consumers with adequate services at reasonable rates while earning a fair retum on their investment (ORS 756-772). Also, the OPUC approves rules the competitive bidding process for the acquisition of new electric resources by investor owned utilities (IOUs).

OPUC assists biomass and cogeneration energy projects with safety codes and electrical power contracts. Safety codes govern equipment designed to transport gas or generate electrical power 
for transmission. OPUC has adopted the National Electric Code (NEC). Plants that connect with utility systems must comply with the NEC. OPUC will intercede in disputes between small power producers and utilities over interpretations of the code.

The OPUC Utility Program makes an independent assessment of all utility rate proposals. It will not allow a utility to add a facility into its rate base if the power sales agreement is unfair to ratepayers. The utility will ask OPUC to review and approve a power sales contract before they sign it.

OPUC staff help the small power producer understand his rights in contract negotiations with a utility. If an impasse is reached in negotiating a contract, OPUC staff will clarify the rights of each party.

\section{Agency: Oregon Building Codes Agency (OBCA)}

Statute: ORS, Chapter 479

The Oregon Building Codes Agency (OBCA) regulates biomass and cogeneration energy projects through local building departments. In less populated areas, 11 OBCA field offices issue permits and conduct inspections.

Local building, electrical, mechanical, and plumbing permits ensure that facilities are built according to the codes adopted by the OBCA. Local officials issue permits and conduct inspections.

Pressure vessels and permits for boilers must be obtained directly from the OBCA Boiler Section.

OBCA professional licensing and advisory boards list professional engineers, architects, and landscape architects licensed to practice in the state.

\section{Agency: Office of the Fire Marshal, Executive Department}

Statute: ORS, Chapter 476

Local building departments review construction plans to ensure that they conform to the fire, life, and safety provisions adopted by the Office of the Fire Marshal. The division has 12 field offices.

\section{Agency: Oregon Department of Environmental Quality (ODEQ)}

\section{Statute: ORS, Chapter 454}

The Oregon Department of Environmental Quality (ODEQ) reviews plans for biomass or cogeneration projects to improve or maintain air, land, and water quality. 
ODEQ issues permits for air emissions, water discharges, water or waste treatment, and solid waste disposal. Each permit lists operating conditions and pollution limits. ODEQ enforces noise limits. There are no separate noise permits.

The state is divided into five ODEQ administrative regions.

There are also four Air Quality Maintenance Areas (AQMAs). These areas encompass metropolitan Portland, Salem, Eugene-Springfield, and Medford-Ashland. AQMAs contain non-attainment areas, where air quality does not meet one or more federal standards. Air emission limits are stricter for plants located inside AQMAs than in other areas. The Eugene-Springfield AQMA is managed by the Lane Regional Air Pollution Authority.

A developer should meet with the ODEQ regional office. ODEQ can help estimate environmental impacts and tell you which permits, or standards, apply to your project. Addresses are listed in Appendix D.

\section{Agency: Oregon Water Resources Department (OWRD) Statute: Constitution Article XI.D}

The Oregon Water Resources Department (OWRD) administers Oregon laws conceming the use of surface and groundwater. A Water Policy Review Board is composed of seven members appointed by the governor and confirmed by the Senate. It establishes policy to conform with the Surface Water Code and the Ground Water Act.

OWRD permits allocate surface and groundwater and protect critical areas. permits cover diversion of water, hydroelectric power siting, safety of dams, reservoirs, creation of irrigation districts, and ponding. Distribution of the available water supply is carried out by 19 Watermasters (Appendix D).

\section{Agency: Oregon Department of Fish and Wildlife (ODFW) \\ Statute: ORS, Chapters 497, 498, 501, 506, 507, 508, 509, 511, 513}

The Oregon Department of Fish and Wildlife (ODFW) consist of the commission, the director who is appointed by the commission, and a statewide staff numbering more than 600 permanent employees.

The commission formulates the general programs and policies of the state concerning the management of fish and wildlife resources and establishes seasons, methods, and bag limits for recreational and commercial take of the resource.

The ODFW is headquartered in Portland with regional offices in Newport, Clackamas, Corvallis, Roseburg, Bend, La Grande, and Hines. Twenty district offices are also staffed at strategic locations throughout the state. The ODFW operates a variety of facilities designed to enhance fish 
and wildlife resources, including 34 fish hatcheries, one game farm, numerous wildlife areas, public shooting grounds, hunting and fishing access sites, and several research stations.

\section{Agency: Oregon Department of Parks and Recreation (ODPR) \\ Statute: ORS, Chapter 390}

The Oregon Department of Parks and Recreation (ODPR) is responsible for the acquisition, improvement, maintenance, and operation of Oregon's state park system. The system is directed by the state parks administrator through a headquarters staff in Salem and five regional park supervisors stationed throughout the state.

In addition to operating state parks, the division gives technical assistance to local government agencies on park matters, develops and maintains the Statewide Comprehensive Outdoor Recreation Plan, and administers the Federal Land and Water Conservation Fund matching grant program in Oregon. The division also administers several special programs.

\section{Agency: Oregon Advisory Committee in Historic Preservation (OACHP) Statute: ORS, Chapter 390}

The Oregon Advisory Committee in Historic Preservation (OACHP) consists of nine members recognized professionally in the fields of history, architectural history, architecture, archaeology, and other disciplines as may be appropriate; one member representing the public at large; and one American Indian. The members are appointed by the governor.

The committee is charged with reviewing nominations to the National Register of Historic Places from the state of Oregon, and recommending approved nominations to the State Historic Preservation Officer pursuant to the National Historic Preservation Act of 1966. The committee also reviews the Statewide Plan for Historic Preservation.

\section{Oregon State Permitting and Licensing Requirements}

It is important for the site developer to initiate the permitting process in the early stages of project development. Specific time requirements may be found in the sections describing the individual permits.

In spite of appearing as a series of barriers to developers. the permitting process may actually be beneficial. By corresponding with appropriate agency officials during the preliminary design and analysis phase, potential problems with a particular site or design can be spotted early. Appropriate modification can then be made, thus avoiding last-minute delays. 


\section{Table 6}

\section{Do You Need a Permit?}

Or Do You Need to Notify Authorities?

YES - if, for example ...

$\underline{\text { Reference }}$

Page

You build a large plant for power (25 MW+)

EFSC

Your plant affects sensitive areas such as wetlands, or is federally funded

Planning

Your process emits dust, smoke, or gases

ODEQ-Air Quality

You make changes to a plant that will result in changes in emissions

ODEQ-Air Quality

Your plant will locate in an Air Quality

Maintenance Area

ODEQ-Air Quality

You discharge wastes into state waters, or build a waste water treatment

and/or disposal system

ODEQ-Water Quality

You use surface water, or more than

5,000 gallons per day of groundwater

Water Resources

\section{Minimum Time Lapse Before Approval}

Months Prior to Construction

Energy Facility Sit Certificate

Zoning or Land Use Permit

ODEQ Land Use Compatibility Statement

ODEQ Air Quality: Notice of Construction and Approval of Plans

Air Contaminant Discharge Permit (ACDP)

(May be up to 12 months

if data required)

Water: National Pollutant

Discharge Elimination

System (NPDES)

Water Pollution Control

Facility (WPCF)

Solid Waste Permit

\section{$\begin{array}{llllllllllll}12 & 11 & 10 & 9 & 8 & 7 & 6 & 5 & 4 & 3 & 2 & 1\end{array}$}
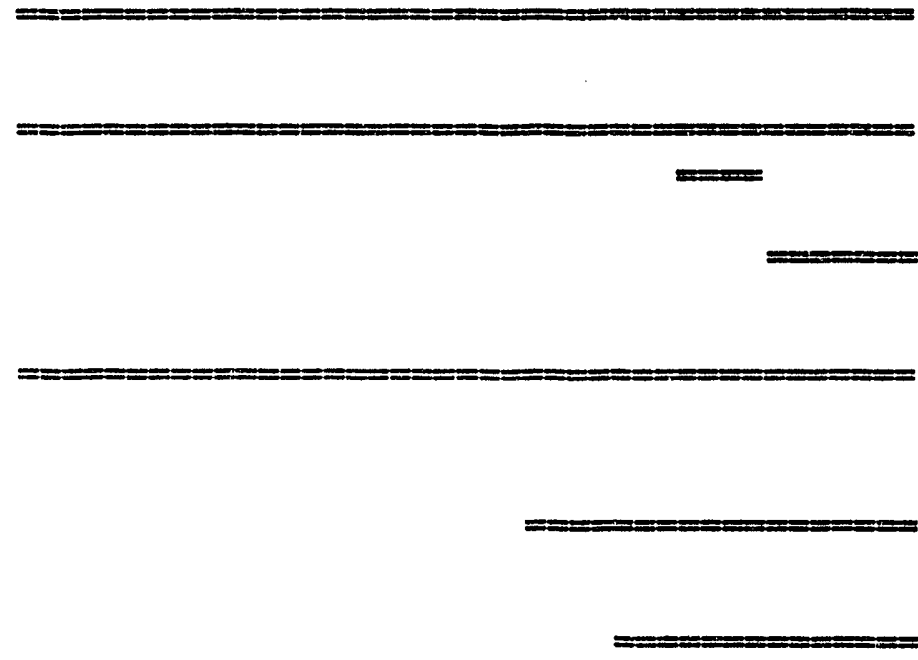

$=$

Figure 7: Calendar fe - Timing Typical Permits 


\section{Air Quality \\ Permit or Regulation: Air Contaminant Discharge Permit (ACDP) \\ Statutory Authority: ORS 468, OAR 340-20-140--340-20-185, \\ Fees, ORS 340-20-155 \\ Agency: Oregon Department of Environmental Quality (ODEQ)}

An Air Contaminant Discharge Permit is issued for almost any commercial or industrial scale biomass or cogeneration project. The Oregon Department of Environmental Quality (ODEQ) may decide after review that a small project either does not require an Air Contaminant Discharge Permit or should file only a "Notice of Construction and Approval of Plans."

Table 7

Summary of Air Quality Permits

Permit Required

Air Contaminant

Discharge Permit

(ACDP)

Notice of

Construction

and

Approval of Plans
Site

All

All

All

All
Fue

Any

Any

Any

An

None
Product, Rate, Other Conditions

Any air quality problem Equipment change causes emissions change

For sources not large enough for ACDP as follows: $400,000 \mathrm{BtuH}$ or more

Air pollutants from any process

Air Quality Maintenance Areas (AQMAs) is a specific populated area where air quality is a problem for one or more pollutants. These are Portland-Vancouver, Salem, Eugene-Springfield, and Medford-Ashland.

ODEQ uses the Air Contaminant Discharge Permit (ACDP) to regulate most stationary sources of air pollution. The permit details conditions a source must meet to comply with air quality standards. ODEQ administers both state and federal rules. Special rules for hazardous air pollutants, the Prevention of Significant Deterioration (PSD) (page 119), or New Source Performance Standards (NSPS) (page 118) are included as part of an ACDP. No separate permit is necessary. 


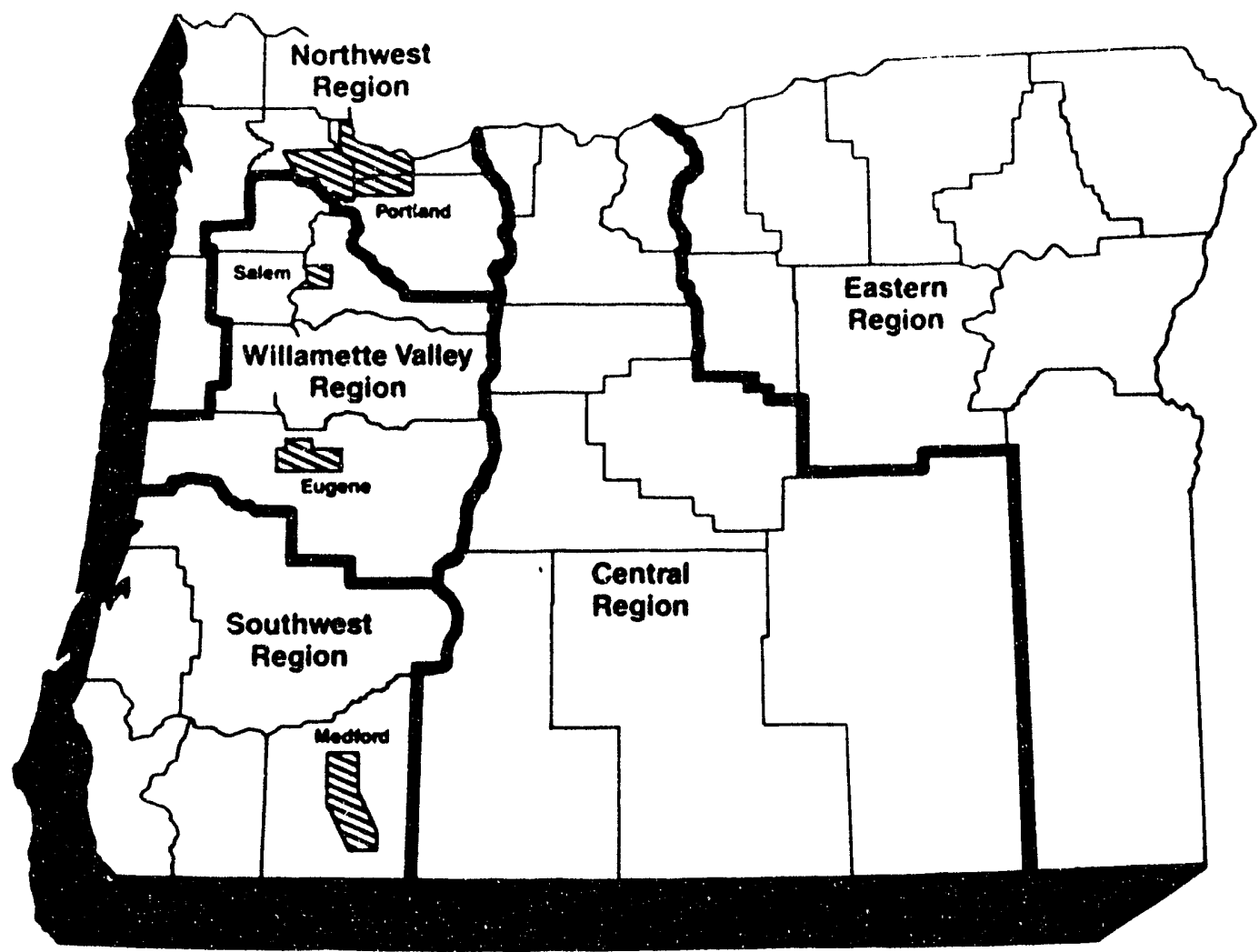

Air Quality Maintenance Areas

- Precise non-attainment area boundaries are different for various pollutants. Spocitic maps are available from DEQ.

Figure 8: Oregon's Air Quality Regions and Air Quality Maintenance Areas 
Table 8

\section{Emission Standards and Regulations Included in an Air Contaminant Discharge Permit}

\begin{tabular}{|c|c|c|c|}
\hline Standards or Rules & $\underline{\text { Site }}$ & Fuel & Product, Rate, Other Conditions \\
\hline Miscellaneous Rules & All & Any & \\
\hline $\begin{array}{l}\text { Non-attainment Area } \\
\text { Source Requirements }\end{array}$ & AQMA & Any & $\begin{array}{l}\text { Emissions exceed significant rates } \\
\text { Tables } 12,13\end{array}$ \\
\hline $\begin{array}{l}\text { Source Emission } \\
\text { Reduction Plan } \\
\text { (SERP) }\end{array}$ & AQMA & Any & $\begin{array}{l}\text { Emissions exceed specified rates } \\
\text { Table } 14\end{array}$ \\
\hline $\begin{array}{l}\text { New Source } \\
\text { Performance } \\
\text { Standards } \\
\text { (NSPS) }\end{array}$ & All & Any & $\begin{array}{l}\text { Electric } 250 \text { million BtuH or more } \\
\text { heat input }\end{array}$ \\
\hline $\begin{array}{l}\text { Prevention of } \\
\text { Significant }\end{array}$ & Outside & \multicolumn{2}{|c|}{ AQMA or impact non-attainment or Class I area } \\
\hline $\begin{array}{l}\text { Deterioration } \\
\text { (PSD) }\end{array}$ & & Any & $\begin{array}{l}\text { Emit more than } 250 \text { tons/year of } \\
\text { any pollutant }\end{array}$ \\
\hline $\begin{array}{l}\text { Hazardous Air } \\
\text { Pollutants }\end{array}$ & All & Any & $\begin{array}{l}\text { Emit asbestos, mercury, beryllium } \\
\text { or other specified by ODEQ or EPA }\end{array}$ \\
\hline
\end{tabular}

Permits must be renewed periodically. The ACDP can be issued for periods up to 10 years. Five-year permits are typical. Permit conditions can include:

- limits on total suspended particulates (TSP) released per year, or within any 24 hour period

- limits on other pollutants

- requirements to maintain pollution control equipment

- requirements to notify ODEQ of process upsets which would temporarily increase emissions

- requirements to reduce emissions in case of air pollution emergencies, "emergency episode plans"

- monitoring, periodic measurement of specific pollutants.

Approximate Time Required to Process

ODEQ must act on a complete application within 6 months. If monitoring is needed, you may need 9 to 12 months to complete the application. 
Permit or Regulation: Notice of Construction and Approval of Plans

Statutory Authority: ORS 468, OAR 340-30-020-340-20-032,

Fees ORS 340-30-155

Agency: Oregon Department of Environmental Quality (ODEQ)

A Notice of Construction and Approval of Plans Permit is issued for projects that are too small for an Air Contaminant Discharge Permit but may produce significant sources of air pollution.

Approximate Time Required to Process

It takes approximately 30 to 90 days to obtain permit.

Permit or Regulation: Requirements for Sources in Non-Attainment Areas

Statutory Authority: ORS 46. OAR 340-20, Sections 220-345

Agency: Oregon Department of Environmental Quality (ODEQ)

Air Quality Maintenance Areas (AQMAs) contain non-attainment areas where air quality does not meet federal standards. Rules for "major" sources locating in AQMAs keep new sources from interfering with the Oregon Department of Environmental Quality (ODEQ) strategies to bring these areas into compliance with federal air quality standards.

"Major" air pollution sources have emission rates equal to or greater than those shown in Table 9, and for the Medford-Ashland AQMA the specific rates are shown in Table 10.

If your project will be a "major" source, an ACDP will not be issued and construction cannot begin until you meet the conditions described below.

1. Emissions must be controlled to a level referred to as "Lowest Achievable Emission Rate" (LAER). This level is stricter than the "Best Available Control Technology" (BACT). LAER is often the lowest rate any system has achieved for the pollutant in question.

2. All other "major" sources you own or control in Oregon must comply with air pollution limits under the Federal Clean Air Act.

3. You must show that there is room in the air shed for the source's emission. You must comply with the established "growth increment" for the area. If a non-attainment areas has no growth increment you need to find "offsets," reducing emissions from other sources.

4. Where growth increments exist:

- No single source can use more than 50 percent of the increment remaining.

- A source can use "offsets" to stay within the growth increment.

- If a source can find offsets, it may not use part of an area's growth increment.

- When offsets are necessary, "net air quality benefit" standards and "reasonable further progress" criteria must be met. Consult the ODEQ. 
5. A new facility or a facility that is a "major" source of carbon monoxide (CO) or volatile organic compounds (VOC) must evaluate alternative locations, plant sizes, processes, and control techniques. The benefits of the controlled source must significantly outweigh the environmental and social costs of other alternatives.

6. Major sources of VOC in the Salem Ozone Non-attainment Area must meet conditions 1 and 2 abuve, but are exempt from conditions 3,4 , and 5 .

Table 9

Significant Emission Rates

\begin{tabular}{|c|c|}
\hline Pollutant & $\begin{array}{c}\text { Significant } \\
\text { Emission Rate } \\
\text { (tons/yr) }\end{array}$ \\
\hline Carbon Monoxide (CO) & 100 \\
\hline Nitrogen Oxides $\left(\mathrm{NO}_{\mathrm{X}}\right)$ & 40 \\
\hline Particulate Matter (TSP) & 25 \\
\hline Sulfur Dioxide $\left(\mathrm{SO}_{2}\right)$ & 40 \\
\hline Volatile Organic Compounds (VOC) & 40 \\
\hline Learl & 0.6 \\
\hline Me:cury & 0.1 \\
\hline Beryllium & 0.0004 \\
\hline Asbestos & 0.007 \\
\hline Vinyl Chloride & 1 \\
\hline Fluorides & 3 \\
\hline Sulfuric Acid Mist & 7 \\
\hline Hydrogen Sulfide $\left(\mathrm{H}_{2} \mathrm{~S}\right)$ & 10 \\
\hline Total Reduced Sulfur (including $\mathrm{H}_{2} \mathrm{~S}$ ) & 10 \\
\hline Reduced Sulfur Compounds (including $\mathrm{H}_{2} \mathrm{~S}$ ) & 10 \\
\hline
\end{tabular}

\section{Table 10}

Specific Emission Rates in Medford-Ashland AQMA

\begin{tabular}{|c|c|c|c|}
\hline Pollutant & Tons/Year & Pounds/Day & Pounds/Hour \\
\hline $\begin{array}{l}\text { TSP } \\
\text { VOC }\end{array}$ & $\begin{array}{r}5.0 \\
20.0\end{array}$ & $\begin{array}{r}50.0 \\
200.0\end{array}$ & 10.0 \\
\hline
\end{tabular}


Permit or Regulation: Source Emission Reduction Plan (SERP)

Statutory Authority: OAR 340-27-005--340-27-035. ORS 468.

Agency: Oregon Department of Environmental Quality (ODEQ)

A Source Emission Reduction Plan (SERP) is a plan to reduce emissions from large sources in non-attainment areas, during air pollution emergencies. SERP requirements set clear procedures to follow in the event of extreme levels of air pollution. Sources shown in Table 14 must include a SERP with an Air Contaminant Discharge Permit (ACDP) application.

Actions requested vary with pollution levels. The Oregon Department of Environmental Quality (ODEQ) comprehensive plan for air pollution emergencies describes the action required under "Alert," "Warning," and "Emergency" conditions.

\section{Table 11}

\section{Sources Which Require a SERP}

$\stackrel{\text { Area }}{\text { Portland AQMA }}$
Eugene-Springfield AQMA
Medford-Ashland AQM

Emissions Greater Than...

$\begin{array}{lcl}100 & \text { tons/year } & \text { CO } \\ 100 & " & \text { VOC } \\ 100 & " & \text { TSP } \\ 100 & " & \text { CO } \\ 100 & " & \text { CO } \\ 100 & " & \text { TSP } \\ 100 & " & \text { VOC }\end{array}$

Permit or Regulation: New Source Performance Standards (NSPS)

Statutory Authority: Tille 40, part 60 of the Code of Federal Regulations (CFR) and OAR 340, Division 25, Sections 505-675.

Agency: Oregon Department of Environmental Quality (ODEQ)

New Source Performance Standards were written by the U.S. Environmental Protection Agency (EPA) and adopted by the Oregon Department of Environmental Quality (ODEQ) to control very large pollution sources in over 20 categories.

Biomass sources include:

Combination wood and fossil-fueled

Sludge burning portion of sewage treatment plants

Electric utility steam

Generating units
$73 \mathrm{MW}$ (250 million Btu/hour steam generators heat input)

All sizes

$73 \mathrm{MW}$ (250 million Btu/hour)

heat input 
Stationary gas turbines

Incinerators
Heat input at peak load of 10.7

gigajoules/hour (1,000 HP)

capable of charging 50 tons/day

New sources must test emissions shortly after start-up to show that they meet the NSPS limits described in their ACDP. Often continuous monitoring is required. Tests must take place within 60 days after a plant achieves maximum production or within 180 days from start-up (Table 12).

Discuss NSPS early with the ODEQ. The Oregon Energy Facility Siting Council (OEFSC) coordinates ODEQ permits for power plants that need to follow NSPS rules before issuing an Energy Facility Site Certificate.

\section{Permit or Regulation: Prevention of Significant Deterioration (PSD) Statutory Authority: OAR 340-20-220--340-20-345, ORS 468 Agency: Oregon Department of Environmental Quality (ODEQ)}

Prevention of Significant Deterioration (PSD) rules prevent the decline of air quality where it is better than federal health and welfare standards in Class I wilderness areas, and in non-attainment areas found within Air Quality Maintenance Areas.

PSD rules control new or modified "large" sources outside of AQMAs and Class I areas that have major impact on these areas. PSD conditions must be met to obtain an ACDP prior to construction.

- Large sources are sources which emit more than 250 tons per year of any pollutant.

- Sources have an impact on non-attainment areas if they are located within $50 \mathrm{~km}(31.25$ miles) and if air quality will exceed levels shown in Tables 13 and 14. These levels apply only to the pollutants for which an AQMA is designated. If, for example, an area exceeds federal standards only for $\mathrm{CO}$ and TSP, having $\mathrm{NO}_{\mathbf{x}}$ impacts greater than those cited would not make the source subject to PSD rules. Consult with the ODEQ to verify applicability.

- Sources locating within $10 \mathrm{~km}$ (.61 miles) of a Class I area, that would have a 24-hour air quality impact of 1 microgram per cubic meter of particulates are also subject to PSD rules."

Show that "Best Available Control Technology" (BACT) will be used.

Approximate Time Required to Process

ODEQ must act on a completed ACDP application within 6 months. It can easily take up to 3 months to complete the application if monitoring is not needed, and 15 months if it is. 


\section{Table 12}

\section{New Source Performance Standards}

Combination wood-fired and fossil-fuel -fired steam generators

Sludge burning portion sewage treatment plants

Electric utility steam generating units

Stationary gas turbines

Incirerators
Particulate $-0.10 \mathrm{lb}$. per million Btu/hr heat input.

Opacity of $20 \%$ maximum.

Nitrogen Oxides $\left(\mathrm{NO}_{2}\right)$ $0.70 \mathrm{lb}$. per million Btu/hr heat input for wood. See Rules for Fuel Combinations.

Particulates - $1.3 \mathrm{lbs} / \mathrm{ton}$ of dry sludge input.

Opacity of less than $20 \%$.

Particulate - $.030 \mathrm{lb} /$ million Btu heat input, or

$1.00 \%$ of potential combustion when burning solid fuel.

Opacity of $20 \%$ maximum except for one six-minute period per hour of $27 \%$ maximum opacity.

Nitrogen Oxides - see Rules.

Nitrogen Oxides - See 40 CFR 60.331 for this complicated formula.

Particulate - .08 grains/dry standard cubic foot of exhaust gas corrected to $12 \% \mathrm{CO}_{2}$.

\section{Table 13}

Maximum Pollutant Levels Allowed by PSD Rules

Average

Measuring $\mathrm{SO}_{2}$

Time
Micrograms per Cubic Meter TSP

$\mathrm{NO}_{2}$

$\mathrm{CO}$

$\begin{array}{lrrrr}\text { Annual } & 1.0 & 0.2 & 1.0 & \\ \text { 24-hour } & 5.0 & 1.0 & & 500 \\ \text { 8-hour } & 25.0 & & & 2,000 \\ \text { 3-hour } & & & & \end{array}$




\section{Table 14}

\section{PSD Allowable Increments \\ Maximum Allowable Increase in Pollution Levels in Micrograms per Cubic Meter}

$\begin{array}{lll}\text { Pollutant } & \begin{array}{c}\text { Class I } \\ \text { Areas }\end{array} & \begin{array}{l}\text { Eisewhere } \\ \text { in Oregon }\end{array}\end{array}$

Particulate matter:

Annual geometric mean 5

24-hour maximum 10

Sulfur Dioxide:

Annual arithmetic mean $\quad 2 \quad 20$

24-hour maximum $\quad 5.91$

3-hour maximum $\quad 25 \quad 512$

Permit or Regulation: Emission Standards and Procedural Requirements for

Hazardous Air Pollutants

Statutory Authority: OAR 340-25-450--340-25-480 (Emission Standards and Procedural

Requirements forHazardous Air Contaminants). ORS 468

Agency: Oregon Department of Environmental Quality (ODEQ)

Sources of hazardous air pollutants are those which emit asbestos, mercury, or beryllium. The Oregon Department of Environmental Quality (ODEQ) or the Environmental Protection Agency (EPA) may add pollutants to this list.

There are only three biomass energy sources likely to have emissions in these three categories:

1. boilers buming demolition or other material which contains asbestos

2. sewage sludge incineration or sludge drying plants (mercury emissions)

3. high volume waste or garbage incinerators (mercury emissions).

ODEQ's prlicy is to proceed cautiously with source of hazardous air pollutants. A new source proposing to burn exotic materials or ninaterials which might be expected to produce toxic pollutants should expect to be carefully reviewed by ODEQ, and probably strictly controlled. Examples could be processes which burn the following:

- rubber

- industrial waste materials with plastics or exotic chemicals

- solvent byproduct distillates or wastes

- PCBs

- $\quad$ pesticides or herbicides

- paint residues

- other organic chemicals. 
Source of pollutants which ODEQ perceives to be potentially hazardous are addressed on a caseby-case basis with specific conditions included in the source's ACDP. ODEQ's general rules authorize them to require a level of control referred to as highest and best practicable treatment.

Sources of asbestos emissions are generally limited to no visible emissions.

Sources are required to limit their mercury emissions to 2,300 grams over any 24-hour period. The rules are slightly less restrictive for sewage sludge incineration plants or sludge drying plants. Those sources must limit mercury emissions to 3,200 grams per 24-hour period.

In addition to standard requirements, ODEQ will probably request the following:

- information on process material flow

- information on the percentage by weight of hazardous contaminants contained in the processed materials

- a description of control equipment for each emission point, including primary and secondary control devices and their estimated control efficiency.

Sources must also notify ODEQ 30 to 60 days in advance of the date operation is to begin.

The source testing described in miscellaneous ODEQ requirements will probably be required of sources of hazardous pollutants.

ODEQ will generally cite OAR 340-20-001 for exotic emissions other than asbestos, beryllium, and mercury.

\section{Construction}

\section{Permit or Regulation: Fire, Life, and Safety Review}

Statutory Authority: ORS 456-930-885, 456-915-950, 447-210-280, 476.030

Agency: Oregon Building Codes Agency (OBCA)

State law requires that construction plans be reviewed for compliance with fire, life, and safety provisions of the Uniform Building Code (UBC) and Uniform Mechanical Code (UMC). Make certain that your construction plans are designed to conform to these codes.

Typical biomass facilities will be designed for B-2 occupancy, but alcohol plants, methane digesters, and other plants which produce or store flammable substances must be designed to $\mathrm{H}-2$ occupancy. Design standards are followed by the professional engineers and architects, who are familiar with the UBC and UMC requirements. 
Many local building departments perform fire, life, and safety reviews of construction land while reviewing building permit applications. Where local governments, usually smaller jurisdictions, do not have this responsibility, applicants should submit their construction plans to the local building department and to the Oregon Building Codes Agency (OBCA) at the same time.

Further information regarding fire, life, and safety reviews may be found at the OBCA.

\section{Permit or Regulation: Uniform Building Code, (Building, Electrical, Mechanical, Plumbing) Statutory Authority: ORS Chapter 479 Agency: Oregon Building Codes Agency (OBCA)}

Building permits are issued by the local building department, and are not issued until the use of the site is approved by the local planning department. Permits ensure that construction plans meet state requirements. Cities and counties differ in the amount of responsibility they assume for plan review and inspection. The Oregon Building Codes Agency (OBCA) assists some areas through its field offices.

Buildings more than 20 feet in height or 4,000 sq. $\mathrm{ft}$. in size, and energy plants and processes that require engineering judgment or affect public health and safety, must be designed by a licensed architect or engineer. Electrical plans must be stamped by a registered electrical engineer.

Approximate Time Required to Process

Most permits are granted within 3 weeks of application. Complex plans may require longer review time.

Further information regarding fire, life, and safety reviews may be found in ORS 456-930-885, 456-915-950, 447-210-280, 476.030.

\section{Facility Siting and Land Use}

\section{Permit or Regulation: Energy Facility Siting} Statutory Authority: ORS 469.320-469.520. OAR Chapter 345, Division 111. Agency: Oregon Energy Facility Siting Council (OEFSC)

This permit applies to power plants that produce more than $25 \mathrm{MW}$ of electricity. The Oregon Energy Facility Siting Council (OEFSC) is the state's authority for siting major power plants. It regulates and monitors construction and operation. Figure 9 shows the OEFSC site certification application process. 


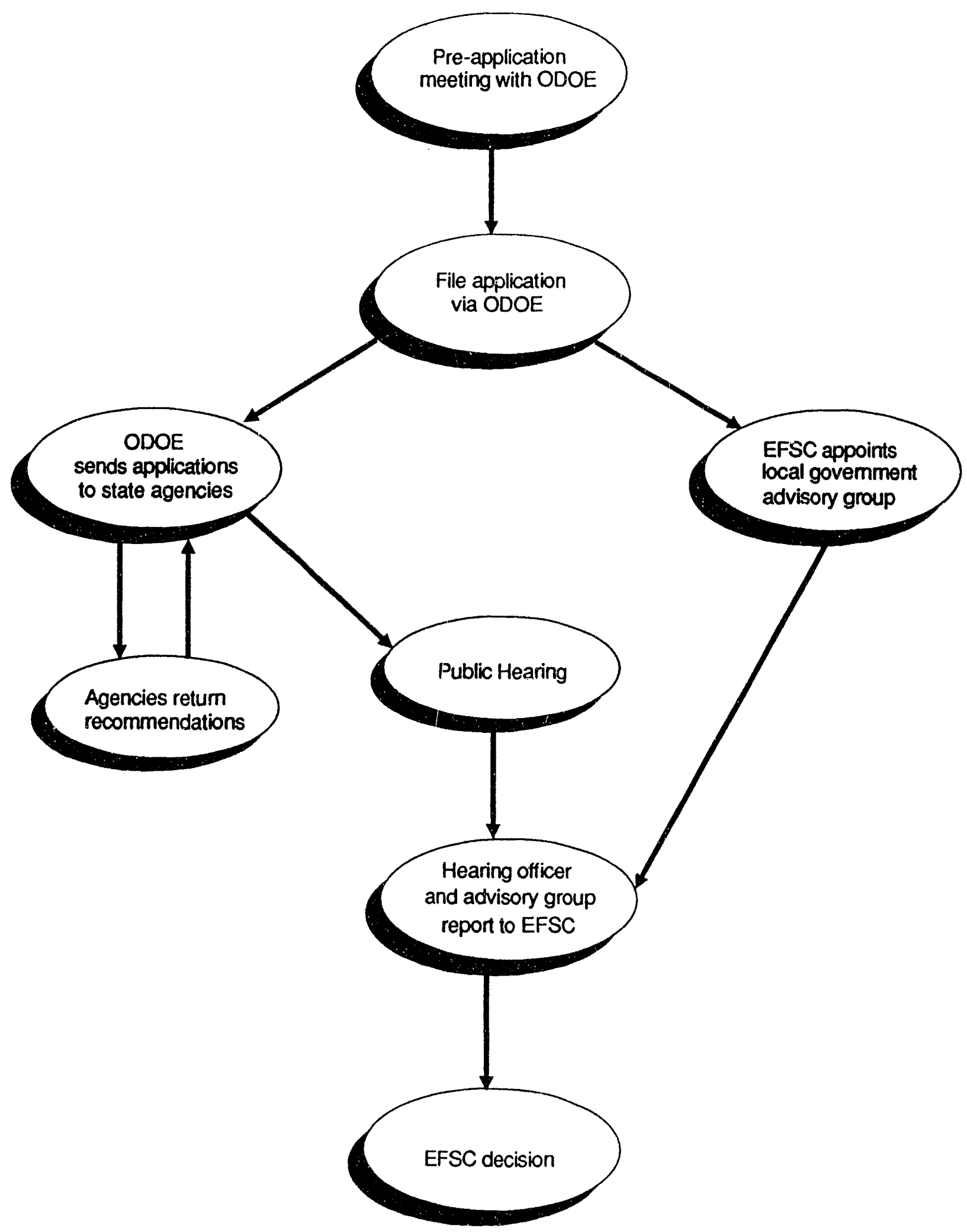

Figure 9: Energy Facility Siting Council Application Process Diagram 
OEFSC guides all permit applications. It coordinates project review by state and local agencies. Its final decision is binding on all state and local agencies. All interested persons and govemment agencies have access to the OEFSC process. Energy facility siting includes a public hearing.

Each site certificate includes conditions for construction and operation. These conditions are proposed, debated, and adopted through a contested hearing.

Approximate Time Required to Process

It takes approximately 6 to 12 months after the complete application is filed to obtain the permit.

\section{Oregon's Land Use Planning Process}

All cities and counties have Land Conservation and Development Commission (LCDC) approved comprehensive plans. The LCDC supervises planning in Oregon through the Department of Land Conservation and Development Department. From 1974 to 1976, the LCDC adopted 19 statewide planning goals (Table 15). Local governments adopt a comprehensive plan and state how planning, zoning, and development will be consistent with LCDC goals. The land use approval process is shown in Figure 10 on page 139.

\section{Table 15}

\section{Titles of LCDC Statewide Planning Goals}

Citizen Involvement

Agricultural Lands

Recreational Needs

Housing

Transportation

Urbanization

Coastal Shorelands

Ocean Resources

Areas Subject to Natural Disasters \& Hazards

Open Spaces, Scenic \& Historic Areas, \& Natural Resources

\author{
Land Use Plawning \\ Forest Lands \\ Economy of the State \\ Public Facilities and Services \\ Energy Conservation \\ Willamette River Greenway \\ Beaches and Dunes \\ Air, Water, and Land Resources Quality
}

For a complete description, request "Statewide Planning Goals and Guidelines" from LCDC.

\section{Coordination with Other Agencies}

The Oregon Department of Environmental Quality (ODEQ) requires a Land Use Compatibility Statement to be signed by a representative from local government. OEFSC appoints advisers from the local governing body. Other agencies also require local government authorization before permits are issued. 
Permit or Regulation: Land Use Compatibility Statement

Statutory Authority: ORS 197.180. OAR, Divisions 30 and 31

Agency: Oregon Department of Environmental Quality (ODEQ)_Air, Water, Solid Waste,

Land Use Compatibility

An Oregon Department of Environmental Quality (ODEQ) permit will not take effect until you have a Land Use Compatibility Statement. The Statement shows that the proposed project complies with Land Conservation and Development Commission's (LCDC) statewide planning goals or with an acknowledged land use plan.

\section{A-95 Review}

When a project receives financing from federal agencies, the local planning department coordinates an A-95 review. Federal and state agencies like the Historic Preservation Office, Fish and Wildlife, Department of Energy, and others will be asked to comment. A-95 review will extend time for land use approval.

Table 16

When to Submit Land Use Compatibility Statements

A. Statement Required BEFORE Permits Become EFFECTIVE Air Contaminant Discharge Permit (ACDP)

B. Statement Required BEFORE Permit is ISSUED

Water Pollution Control Facility (WPCF)

National Pollutant Discharge Elimination System (NPDES)

C. Statement Required WITH Application

On-site Sewage Disposal Permits

Solid Waste Permits

Hazardous Waste Disposal License

Sewage and Waste Water Industrial Permits

\section{Noise Control}

Permit or Regulation: Noise Control for Industry and Commerce

Statutory Authority: OAR 340-35-035 and ORS 467

Agency: Oregon Department of Environmental Quality (ODEQ)

The Oregon Department of Environmental Quality (UDEQ) controls noise through standards, review, and mitigation actions. There is no noise permit. A compliance schedule for certain high noise sources may be required, with intended actions listed. 
If there is reason to believe that anyone may object to the noise levels to be generated by a new biomass or cogeneration plant, you should request the optional pre-construction review by ODEQ. Provide ODEQ with details of the type of equipment to be used, its location, and barriers to noise transmission on the site.

Sources exempt from noise regulations include:

- tire or road vehicle noise if the vehicles meet standards

- construction site activity

- capital equipment construction or maintenance

- agricultural activity

- tree harvesting

- other exceptions authorized by ODEQ.

\section{Table 17}

New Industrial sind Commercial Noise Source Standards (OAR 340-35-035)

Allowable Statistical Noise Levels in Any One Hour

7 a.m. - 10 p.m.

10 p.m. - 7 a.m.

L50 - $55 \mathrm{dBA}$

L50 - $55 \mathrm{dBA}^{\circ}$

$\mathrm{L}_{10}$ - $60 \mathrm{dBA}$

$\mathrm{L}_{1}-75 \mathrm{dBA}$

$\mathrm{L}_{10}$ - $55 \mathrm{dBA}$

$L_{1}-60 \mathrm{dBA}$

\section{Table 18}

Industrial and Commercial Noise Source Standards for Quiet Areas

(OAR 340-35-035)

Allowable Statistical Noise Levels in Any One Hour

7 a.m. - 10 p.m.

10 p.m. - 7 a.m.

L50 - $50 \mathrm{dBA}$

$\mathrm{L}_{10}-55 \mathrm{dBA}$

$\mathrm{L}_{50}$ - $45 \mathrm{dBA}$

$\mathrm{L}_{1}-50 \mathrm{dBA}$

$\mathrm{L}_{10}-50 \mathrm{dBA}$

$\mathrm{L}_{1}-55 \mathrm{dBA}$. 
Table 19

\section{Median Octave Band Standards for Industrial and Commercial Noise Sources}

(OAR 340-035)

\begin{tabular}{|c|c|c|}
\hline \multicolumn{3}{|c|}{ Allowable Octave Band Sound Pressure Levels } \\
\hline $\begin{array}{c}\text { Octave Band Center } \\
\text { Frequency } \\
\mathrm{Hz}\end{array}$ & 7 a.m. -10 p.m. & 10 p.m. - 7 a.m. \\
\hline $\begin{array}{c}31.5 \\
63 \\
125 \\
250 \\
500 \\
1,000 \\
2,000 \\
4,000 \\
8.000\end{array}$ & $\begin{array}{l}68 \\
65 \\
61 \\
55 \\
52 \\
49 \\
46 \\
43 \\
40\end{array}$ & $\begin{array}{l}65 \\
62 \\
56 \\
50 \\
46 \\
43 \\
40 \\
37 \\
34\end{array}$ \\
\hline
\end{tabular}

\section{Permit or Regulation: Boiler or Pressure Vessel}

Statutory Authority: OAR Chapter 814-25-000--814-25-100. ORS 183. and 480.510-990 "Boiler and Pressure Vessel Law" (as amended by 1983 legislature)

Agency: Oregon Building Codes Agency (OBCA)

The law is intended to protect the safety of the people of Oregon from the hazard of fires and explosions caused by boilers and pressure vessels; to assure that only qualified persons do welding on boilers and pressure vessels; and to assure that vessels are properly manufactured, installed, repaired, operated, and maintained.

A "boiler" is a closed vessel or vessels intended for the heating or vaporizing of liquids to be used externally to such vessel or vessels by the application of heat from combustible fuels, electricity, or nuclear energy.

A boiler's "related appurtenances" include (but are not limited to) pressure piping directly connected and related to the safe operation of a boiler, and pressure piping beyond the second valve from the boiler.

"Pressure vessel" means containers for the containment of pressure, either intemal or extemal. This pressure may be obtained from an external source or hy the application of heat from a direct or indirect source, or any combination thereof. 
The law applies to any boiler or pressure vessel to be installed, altered, or repaired in the state of Oregon. It adopts the safety standards of the "Boiler and Pressure Vessel Code" and the "Code for Pressure Piping" of the American Society of Mechanical Engineers (ASME).

Exemptions include:

- a boiler or pressure vessel under federal safety regulations or control

- automatic utility water heaters not exceeding 120 gallons, that contain only water, and operate at less than $210^{\circ} \mathrm{F}, 150$ pounds per square inch (psi) and 200,000 BtuH

- certain small sizes of pressure vessels and tanks

- pressure vessels that operate at pressures of less than $15 \mathrm{psi}$ and outside any structure

- farm boilers operated at less than 15 psi gauge pressure and used solely for agricultural purposes, except for greenhouses.

\section{Solid Waste}

\section{Permit or Regulation: Solid Waste Disposal}

Statutory Authority: OAR 340-61-005--340-61-036, ORS 459. Agency: Oregon Department of Environmental Quality (ODEQ)

The permit applies to land and facilities used for disposal of solid waste. The Oregon Department of Environmental Quality (ODEQ) defines "disposal site" and other terms that apply to biomass energy process. Disposal sites include energy recovery facilities, incinerators, solid waste storage, handling, and transfer sites.

Disposal sites must obtain solid waste permits before they are established, operated, substantially altered, expanded, or improved. The ODEQ can set requirements for reporting, monitoring, entry, and inspection.

Approximate Time Required to Process

The approximate timing is 60 days.

Permit or Regulation: Special Rules for Incineration

Statutory Authority: OAR 340-61-045 and ORS, Chapter 459.

Agency: Oregon Department of Environmental Quality (ODEQ)

The Oregon Department of Environmental Quality (ODEQ) has special solid waste permit requirements for incinerators at disposal sites. Talk to ODEQ about the requirements that will apply to your proposed incinerator. Design the system to comply with them. 


\section{Table 20}

\section{Do You Need a Solid Waste Permit?}

Fuel or Feedstock Storage

Wood fuel storage piles.

Yard debris storage area.

Agricultural residue

fuel storage.

Sludge from anaerobic digester conversion of manure to methane.

Stillage from alcohol plants.

Company incinerator to burn in-house byproducts.

Solid waste incinerator burning solid waste delivered by the public or a solid waste collection service.

\section{ODEQ Solid Waste Permit Required?}

No. Hogged fuel is not considered to be useless or discarded, and therefore is not waste according to the definition.

No. Material would not be considered to be waste if it is used within a reasonable time.

No. Same answer.

Confer with ODEQ. Probably not, if spent residue is applied to agricultural lands.

No, if stillage is used as a product. Possibly yes, if stillage were stored as a decaying pile.

Probably not, according to ODEQ's definition of disposal site.

Yes.

Yes.

Sewage sludge burners.

DEQ can require the following detailed information:

- contours

- drainage control

- landscaping

- fencing

- access and on-site roads

- solid waste handling facilities

- truck washing facilities

- ash and residue disposal

- design and performance specifications of incineration equipment

- provisions for testing air emissions of the incinerator.

Incinerators that require permits must satisfy the following conditions:

- All air quality emission standards and regulations that apply must be met.

- Ash and residues must be disposed of in an approved landfill unless another procedures is approved by ODEQ. 
- No waste water is to be discharged to public waters except in accordance with a National Pollutant Discharge Elimination System NPDES permit.

- All-weather access roads are required, and must be designed and maintained to prevent traffic congestion, traffic hazards, dust, and noise pollution.

- The incinerator site is to be designed so that surface drainage will be diverted around or away from the site's operation.

- Fire protection plans must be approved in writing by ODEQ and must comply with pertinent state and local fire regulations.

- Access to the site is to be controlled by means of a complete perimeter fence and lockable gates.

- Sanitary waste disposal must be accomplished in a manner approved by ODEQ or the state or local health agency with jurisdiction over the site.

- If truck washing facilities are provided, they must be hard-surfaced with wash waters conveyed to a catch basin, draining and disposal system approved by ODEQ or the state or local health agency with jurisdiction.

- All solid waste deposited at the site must be confined to the designated dumping area.

- Accumulation of solid wastes and undisposed wastes must be kept to minimum practical quantities.

- There are limits and constraints to salvage activities.

- Litter must be controlled.

- All applicable ODEQ noise limitations must be met.

- Rodent, insect, and disease controls are required.

- ODEQ can require record keeping.

Further information should be obtained by direct contact with the ODEQ Solid Waste Division.

\section{Water Quality/Water Use}

The Oregon Department of Environmental Quality (ODEQ) issues two relevant water quality permits.

1. National Pollutant Discharge Elimination System (NPDES) permits cover all waste water discharges to surface waters. The NPDES is a federal program administered by the state. NPDES covers commercial or industrial plants, municipal sewage treatment plants, confined animal feed operations with point discharges, and mining operations.

2. Water Pollution Control Facility (WPCF) permits apply to waste waters directly disposed of on land or injected into the ground with no direct discharge to surface waters. Land irrigation, evapo-transpiration lagoons, and industrial seepage pits are examples. WPCF is a state program.

The Oregon Water Resources Department (OWRD) regulates the use of state surface waters from rivers and streams, and groundwater from wells or aquifers. 
Permit or Regulation: National Pollutant Discharge Elimination System (NPDES)

Statutory Authority: OAR 340-45-005--340-45-070, ORS 468

Agency: Oregon Department of Environmental Quality (ODEQ)

This permit applies to any project that will release wastes into public waters, unless:

- the discharge is into a sewage system that has valid permits, such as a municipal system, and you have obtained a permit to discharge into that system; or

- The Oregon Department of Environmental Quality (ODEQ) has written, in reply to your application, that no National Pollutant Discharge Elimination System (NPDES) permit is needed.

ODEQ has established water quality goals and regulations for 19 different water basins within Oregon. Water quality permit conditions are considered on a case-by-case basis. The size of the receiving stream and activity (see Table 21 ) are considered.

Approximate Time Required to Process

A permit can usually be issued within 60 to 120 days of receipt of a completed application.

\section{Table 21}

NPDES Permit Application Forms

(OAR 340-45-030)

Permit Category

Any industrial, commercial, manufacturing or mining activity

a. In quantities exceeding 50,000 gallons on any day of the year

b. In quantities of 50,000 gallons or less but which discharges a toxic pollutant

Permit or Regulation: Water Pollution Control Facility (WPCF)

Statutory Authority: OAR 340-45-005--340-45-070, ORS 468. Agency: Oregon Department of Environmental Quality (ODEQ)

Water Pollution Control Facility (WPCF) pernits ensure adequate water treatment in pollution control facilities designed to treat effluents like cannery waste by evaporative ponds or land application. 
These permits apply to construction or operation of a wastewater disposal system that does not discharge to navigable waters. The Oregon Department of Environmental Quality (ODEQ) must approve plans before construction can begin. Requirements are set on a case-by-case basis. A source discharging to a sewage system with a valid National Pollutant Discharge Elimination System (NPDES) or WPCF permit, such as a municipal sewage system, is exempt.

Approximate Time Required to Process

A permit can usually be issued within 60 to 90 days of receipt of a completed application.

\section{Permit or Regulation: General Permit for Water Pollution Discharge Sources Statutory Authority: OAR 340-45-033--340-45-035, ORS 468 Agency: Oregon Department of Environmental Quality (ODEQ)}

When a general permit has been granted for one source, any additional source conducting the same activity is permitted, unless an individual Water Pollution Control Facility (WPCF) or National Pollutant Discharge Elimination Systern (NPDES) permit has been issued.

Water pollution sources where only general requirements gure needed to protect water quality, such as:

- $\quad$ sources which discharge non-contact cooling water, defrost water, heat pump transfer water, or cooling tower blowdown

- sources which discharge continuous or intermittent boiler blowdown water

- $\quad$ log storage ponds

The following information must be submitted to the Oregon Department of Environmental Quality (ODEQ):

- water discharge temperature, volume, and $\mathrm{pH}$

- water discharge quality, chlorine, and flow

- water discharge location.

Several simple effluent tests are required monthly.

Approximate Time Required to Process

ODEQ will determine if a General Permit will apply, within $\mathbf{3 0}$ days. The permit is valid when issued. 


\section{Permit or Regulation: Water Rights Permit (Reservoir Permit, Surface Water Permit,}

Ground Water Permit)

Statutory Authority: OAR 340-45-005--340-45-070, ORS 468.

Agency: Oregon Water Resources Department (OWRD)

A permit to Appropriate the Public Waters of the state of Oregon grants you a right to use the public's water for beneficial purposes. Oregon law says that all Oregon waters from almost all sources belong to the public.

The Oregon Water Resources Department (OWRD) requests a map and completed application for each permit. Any biomass project that will use any surface water (lakes, streams, rivers, waters stored in reservoirs, or other surface sources) or more than 5,000 gallons per day of groundwater must apply. Request either the "Application for a Permit to Appropriate Ground Water" or the ".Application for a Permit to Appropriate Surface Water" from OWRD.

The form requests the following information:

- exact location of a project (legal description and location with respect to a public land survey corner)

- type of use

- well depth and diameter (if applicable)

- amount of water to be used

- description of works (means of diversion, type of pump and motor, pipeline size, etc.)

- date construction will begin and end

- date use will begin

- four prints (or one reproducible print) of a map drawn to a scale of at least four inches to a mile.

There may be special requirements for water works or any water use of Wild and Scenic Rivers:

- You need to locate your project on the District's Water Resources map.

- Ask if water is available at your prospective site.

- Estimate the amount of water your project will use. Ask for all of the water you will need. The water right will be based, however, on your actual use.

\section{Approximate Time Required to Process}

The OWRD grants the permit within 60 days after application. If no water is available, your application and fee are returned.

The following dates are set by law:

- Construction must begin within one calendar year after permit is granted. (Construction may mean purchase of equipment.) No extension of time is allowed during this first year. Each permit is issued for only one year.

- You have until October 1 of the next year to complete construction, and until October 1 of the year following to begin use. These latter two dates can be extended if satisfactory progress is being made. Request a time extension from the Department if necessary. 
After you begin using water, the District Watermaster's staff will inspect your plant. You must be using water for its intended purpose. You won't be allowed to use more water than your permit grants. If you are using less water, your permit will be modified.

A cubic foot per second is approximately equal to 450 gallons per minute or 648,000 gallons per day. This process is straightforward if water is available. You may have problems estimating the amount of water you will use, or meeting the construction dates.

A 30-day legally-required waiting period begins when your application is received. The OWRD distributes a list of applications each week. Protests may be filed during this period.

Contact your District Watermaster, the field office of the OWRD. Addresses are in Appendix C.

\section{Other Permits}

Permit or Regulation: Alcohol Production Permit

Statutory Authority: Title 27, Code of Federal Regulations, Part 201 and Title 26, USC, Chapter 51

Agency: Federal Bureau of Alcohol, Tobacco, and Firearms (BATF)

The Bureau of Alcohol, Tobacco, and Firearms (BATF) of the U.S. Department of Treasury administers federal laws and regulations governing the taxation, production, denaturation, and distribution of fermentation alcohol. It also provides information about current laws to potential producers. Anyone who intends to operate an experimental or commercial alcohol plant will require this permit.

There are two types of permits: regular and experimental. A permit is issued after an application, a plant inspection, and an Intemal Revenue Service Bond to cover estimated tax liabilities. BATF publication 5000.1 describes forms and procedures for a regular commercial permit. Experimental alcohol production permits are issued following application by letter, a plant inspection, and an IRS bond. Experimental permits are issued for a period of 2 years.

Permits for an experimental or farm-scale system include the following:

- letter to the BATF

- nature and purpose of alcohol production

- a description of the plant, production process to be used, and equipment

- security measures to be taken for alcohol storage

- the rate of production expected for an average 15-day period (e.g., 400 gallons at 160190 proof)

- in the case of more discretionary permits, ask the staff about the likelihood of approval; also what might help to speed up the process and decision

- submit a complete application-incomplete applications will result in processing delays

- attend all meetings where the application will be discussed. If there is no one to respond to questions, delays may occur or the permit may be denied. 


\section{Local Permitting and Licensing Requirements}

Within the framework of federal and state regulation, local governments perform duties which can have unique and significant impacts on energy project development. Local governments can set an example by financing and developing energy facilities themselves. They can encourage private development through information distribution and active recruiting of facilities. Cities and counties also regulate energy facilities. Below state-level citing thresholds, the jurisdictions are the primary development permitting authority. They set land use policy which controls the type and location of future developrnent and affect construction techniques by enforcing building and electrical codes. They direct the division of lots through subdivision ordinances. They also regulate the type, mix, and location of land uses using zoning ordinances.

Most county governments require building permits for construction and entail building code, electrical code, and plumbing code compliance. Most counties also have planning and zoning commissions that will review project plans for compliance with comprehensive plans, zoning regulations, and needs for conditional or special use permits. Counties may also have some jurisdiction over construction in or near defined flood plains and over use of, or construction near, county highways. The county courthouse, the county zoning administrator, and the county highway district are the best contacts for determining what permits or approvals will be required.

If a proposed site is within a city's limits or within its area-of-impact, appropriate contact should be made with city officials regarding building permits, zoning regulations, flood plain construction, and highway usage. Contact the city hall of the nearest city for a determination of the required permits and approvals and jurisdiction.

Smaller communities often issue all permits through a single office, such as the Clerk. In some counties, one or more highway districts exist that are responsible for construction and maintenance of roads. These agencies will be the administrators of all permits/approvals having to do with public rights-of-way.

A number of these permits, mainly those administered by the Planning Department, will involve substantial discretionary action on the part of the decision makers, approval being based on conformance of plans with established criteria or standards. Therefore, these decisions will usually be made by elected or appointed officials (city councilmen, county commissioners, or planning and zoning commissioners). Another group of approvals will be based on the adequacy of technical plans. These will generally be the permits listed as being administered by the public works department and building department. Several items will be simply a matter of registration, including the business license and registration of proprietorship. The following is a general description of each of the permits and approvals which may be required.

Zoning ordinances implement policies established in local land use plans and reduce land use conflicts by dictating the type of development allowed within the jurisdiction, the design of those uses, and the way potentially conflicting uses may coexist. 
Policies and standards reflect both technical information and popular opinion. Local land use law often reflects values that are difficult to evaluate objectively. Public participation in a project approval may reveal concerns for property values, neighborhood quality and scenic quality. These subjective values are difficult to put into laws. Few local governments have done more with energy facility regulation than provide a forum for public involvement in siting decisions.

In the absence of attention to the energy resource in the local land use plan, a prospective developer may have to champion a project proposal through the entire land use planning, zoning, and ordinance-writing processes. Such an effort would add many months to a project's lead time and increase its cost. Along the way, design changes are likely or the project may be found infeasible. The local government and public would be involved in broad planning, policymaking, and ordinance issues in the context of community reaction to a proposed project.

\section{Determining Which Permits are Required}

To enable a developer to determine what local permits are necessary for a particular site, and for guidance in obtaining local permits, the following guidelines are provided.

- Determine with certainty within what local jurisdiction the project site lies. Assumptions about jurisdiction are often inaccurate. Even if a site is within the county, it is possible it may be within a city's Area of Impact, which would give the city certain jurisdiction over the project.

- Contact agency staff early to obtain information about permits and to discuss your plans. Go into their office in person to make personal contact and to show your commitment to expediting the permitting process.

- Determine what permits will be required for the proposed project; what information should be provided; the process that will be followed; and time frames, including submittal dates, hearing dates, and the time within which a decision can be expected.

- Get copies of the applicable regulations so you can personally review them and the evaluation criteria. Ask questions if the written regulations vary from information the staff has provided.

- In the case of more discretionary permits, ask the staff about the likelihood of approval; also what might help to speed up the process and decision.

- Submit a complete application. Incomplete applications will result in processing delays.

- Attend all meetings where the application will be discussed. If there is no one to respond to questions, delays may occur or the permit may be denied. 
Local county and/or city governments are responsible for regulating development within local jurisdiction community. The following will provide general information and directions to the appropriate local planning and building departments for obtaining permits and approvals required for a project. These requirements pertain to local zoning and building codes, comprehensive land use and shoreline plans, and local development policies.

\section{Land Use Zoning}

\section{Permit or Regulation: Land Use or Zoning Statutory Authority: ORS Chapter 454 Agency: City or County Planning Department}

This permit applies to any commercial, agricultural, or industrial biomass or cogeneration project.

The local planning department must approve the use of a site for energy conversion before plans can be submitted for building permits.

Some governments require an architectural design review after the use of the site has been approved.

If the energy conversion process does not fit the site zoning class, a conditional use permit (CUP), or an amendment to the General Plan may be necessary.

An application for use of a site is considered during a public hearing where it is denied, approved, approved with conditions, or continued. A continuance refers the application back to planning staff for further review prior to another hearing. At the end of the process, you will receive a letter that will approve or deny your intended use of the site (see Table page __).

Approval is complex. Projects are reviewed to assure protection of public health, safety, and general welfare; to comply with statewide planning goals; and to comply with a city or county comprehensive plan. Local government must: coordinate with other state and federal agencies; consider special purpose zoning like historic preservation sites; and consider water quality, soils suitability, fish and wildlife, noise, and public roads.

Approximate Time Required to Process

It takes approximately 60 to 120 days to approve a site; sometimes over a year. 


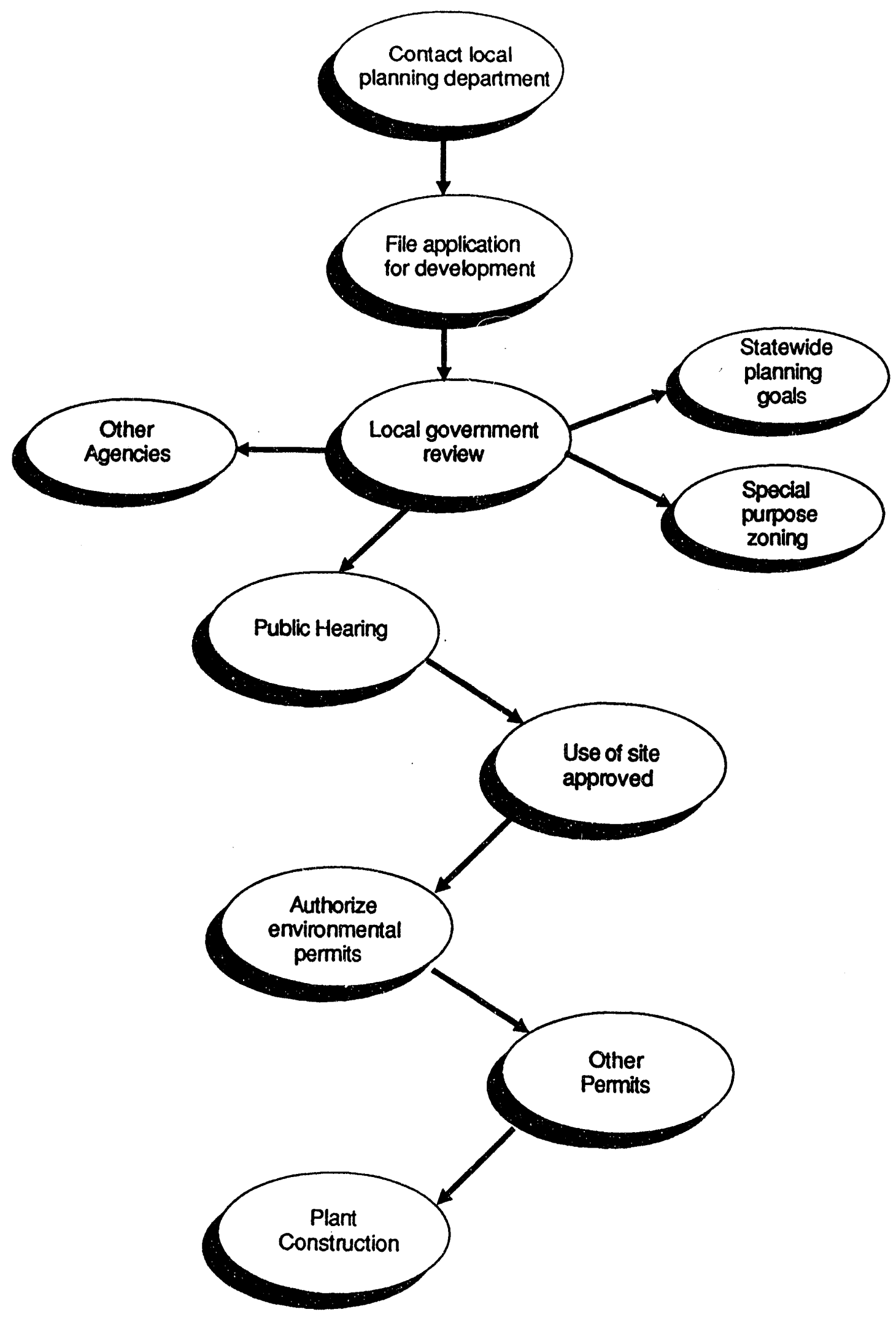

Figure 10: Local Government Land Use Approval Land Use Planning and Permit Process 


\section{Construction}

Permit or Regulation: Building (Building, Electrical, Mechanical, Plumbing)

Statutory Authority: ORS Chapter 479

Agency: City or County Building Departments

Building permits are issued by the local building department. The permits ensure that construction plans meet the state adopted Uniform Building Code (UBC) or the Uniform Mechanical Code (UMC).

Cities and counties differ in the amount of responsibility they assume for plan review and inspection. The Building Codes Agency assists some areas through its field offices.

Building permits are not issued until the use of the site is approved by the planning department.

Buildings more than 20 feet in height or 4,000 sq. $\mathrm{ft}$. in size, and energy plants and processes that require engineering judgment or affect public health and safety must be designed by a licensed architect or engineer.

Electrical plans must be stamped by a registered electrical engineer.

Approximate Time Required to Process

Most permits are granted within 3 weeks of application. Complex plans may require longer review time. 


\section{Permit Summary Sheet \\ WASHINGTON}

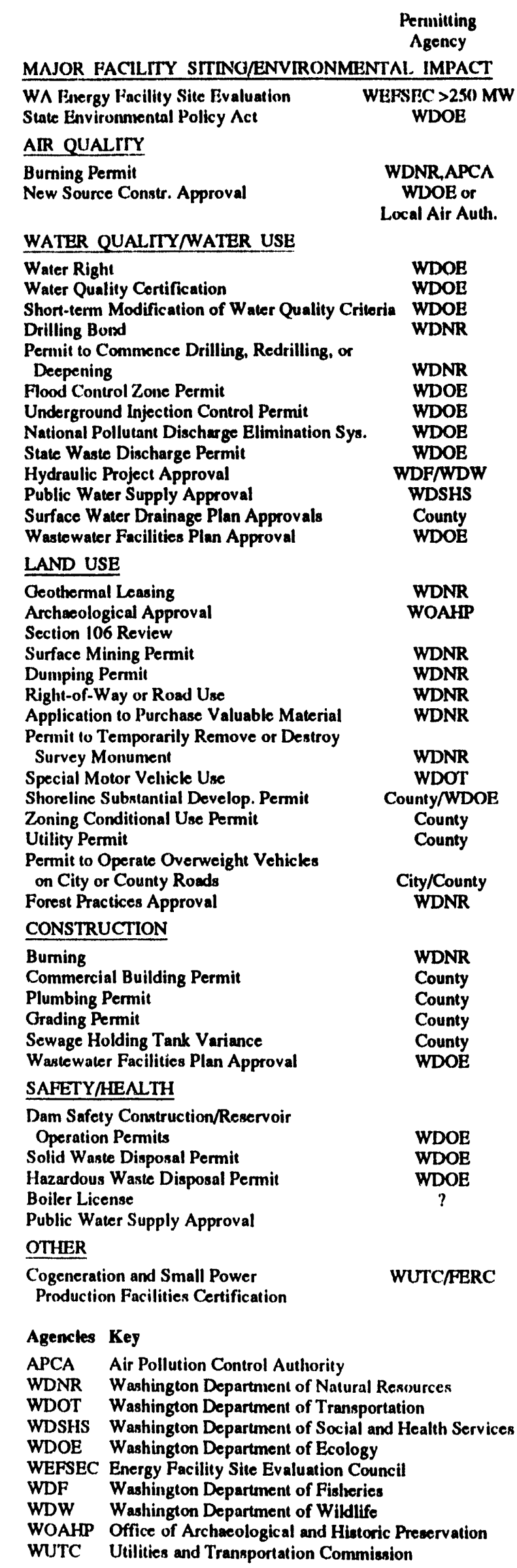




\section{Chapter 5 Washington State}

This chapter is designed to introduce you to state agencies involved in the regulation of cogeneration facilities in Washington State. It briefly describe permits and regulations which state and local governments require before construction of a cogeneration facility begins.

Washington siatutes provide for comprehensive review of proposals to construct and operate cogeneration facilities involved in generating, converting, or transmitting energy in Washington. These requirements are concerned with a wide variety of issues to include construction, legal rights, public safety and health, environmental concerns.

\section{State Regulatory Agencies}

There are several state agencies involved in the regulation of cogeneration facilities. A brief description of each agency's responsibilities are summarized in this subsection.

\section{Agency: Washington Department of Ecology (WDOE) Statutory Authority: 43.21A.040 RCW}

It is a fundamental and inalienable right of the people of the state of Washington to live in a healthful and pleasant environment and to benefit from the proper development and use of its natural resources. As the population of the state grows, the need to provide for increasing industrial, agricultural, residential, social, recreational, economic and other needs places an increasing responsibility on all segments of society to plan, coordinate, restore and regulate the use of the natural resources in a manner that will protect and conserve clean air, pure and abundant waters, and the natural beauty of the state. As the state environmental management and protection agency, the Washington Department of Ecology (WDOE) is responsible for ensuring that air, water, and related land resources of the state are protected and fully utilized for the greatest benefit to the people of the state.

The State Environmental Policy Act (SEPA) requires that proposed development in the state of Washington be evaluated to identify the environmental impacts that will result before state and local permit decisions are made. To assist developers in obtaining information on state permits, WDOE has established the Environmental Permit Information Center (EPIC). The EPIC can answer your general questions and provide certain services during the process of obtaining state environmental permits for your proposed development. By calling EPIC's Permit Information Line at (206) 459-6022, you will learn about state environmental permits, public notice requirements, processing times, and appeal procedures as well as required federal and local permits. You will also be told which agencies are involved and their locations. A Permit Application 
Packet tailored to the specific needs of your project will be assembled and sent to you. If you have a major project, a Natural Resource Coordinating Committee Project Facilitator can assist with preapplication needs. The project facilitator will, on your behalf, consult with agencies and as-semble a preliminary list of required permits, estimated time frames, and a description of poten-tial issues. The project facilitator will also, at your request, arrange preapplication meetings with the agencies for consultation and information.

You may apply for permits individually or you may use a special process which will help you obtain several environmental permits as a package. The Environmental Coordination Procedures Act (ECPA) was adopted by the Washington State Legislature in 1973 to coordinate permit procedures. This process gives you the option of submitting a Master Application form to assist in obtaining necessary permits for the development you propose to undertake. If you use this service, the EPIC will act as your permit coordinator and assist you from application through final disposition.

The permits and approvals listed in Table 22 are those mandated by the Washington State Legislature to be coordinated through ECPA.

\section{Agency: Washington Department of Fisheries (WDF) Statutory Authority: Chapter 75.08 RCW}

Under state law, the Washington Department of Fisheries (WDF) is charged to preserve, protect, perpetuate, and manage the food fish (e.g., salmon, smelt, sturgeon) and shellfish in state and offshore waters (RCW 75.08.012).

Any person desiring to conduct work that will use, divert, obstruct, or change the natural flow or bed of any stream secure written approval from the department (Fisheries or Wildlife) having jurisdiction of the site. This might apply to energy generation projects that require surface water for cooling or as an additional source of water for injection. The WDF is actively involved in consulting and conducting feasibility studies to evaluate and mitigate impacts on fisheries resources.

\section{Agency: Washington Department of Health (WDOH) Statutory Authority: Chapter 43.70 RCW}

The social and economic vitality of the state depends on a healthy and productive population. The Washington Department of Health (WDOH) is responsible for helping to preserve public health by monitoring the general oversight and planning for all the state's activities as they relate to the health of its citizenry. 


\section{Table 22}

\section{Environmental Coordination Procedures Act (1973) Coordinated Permits}

\section{Permits}

Shoreline Management

Substantial Development

Septic Tanks

Flood Control Zones

Miscellaneous Permits

Weather Modification

New Source Construction

Buming

- Commercial

- Agricultural

- For Seed

- Forest Material

- Household

Dams - 10 acre-feet or larger

Reservoirs - 10 acre-fee or larger

Water right (surface and ground)

- Appropriation

- Change

Waste Treatment Facilities

Waste Discharge - Groundwater

NPDES - Waste Discharge From Point Source

Water Quality Certification

Hydraulics Projects

Forest Practices

Dumping of Mill or Forest Waste

Operating Power Machinery in Dead or Down Timber

Rendering Plant Operations

Surface Mine Reclamation

Removal of Floating or Beach Logs

Oil and Gas Drilling

Public Water Supplies

\section{Agencies}

- County and City Government

- WDOE, WDOH, County Government

- WDOE, County Govemment

- County and City Govemment

- WDOE \& Regional Air Pollution Control Authority

- WDOE \& Regional Air Pollution Control Authority

- WDOE \& Regional Air Pollution Control Authority

- WDOE \& Regional Air Pollution Control Authority

- WDOE \& Regional Air Pollution Control Authority

- WDOE and WDNR

- County and City Government

- WDOE

- WDOE

- WDOE

- WDOE

- WDOE

- WDOE

- WDOE

- WDOE

- WDW and WDF

- WDNR

- WDNR

- WDNR

- WAGR

- WDNR

- WDNR

- WDNR

- WDOH
Legend:
APCA
DNR
WAGR
WDF
WDOE
WDOH
WDW
- Air Pollution Control Authority
- Washington Department of Natural Resources
- Washington Department of Agriculture
- Washington Department of Fisheries
- Washington Department of Ecology
- Washington Department of Health
- Washington Department of Wildlife

The agency works with local Health Departments and local governments to strengthen the state and local governmental partnership in providing public protection. It also works with other federal, state and local agencies and in facilitating their involvement in planning and implementing health preservation measures. 
Agency: Washington Department of Labor and Industries (WL\&I) Statutory Authority: Title 296 WAC and Chapter 43.22 RCW

The Washington Department of Labor and Industries (WL\&I) is responsible for the protection, safety, health, and welfare of employees for all occupations. It is also responsible for electrical inspection, elevator inspection, boiler inspection and registration and regulation of contractors. It is organized into five divisions:

1. Industrial Insurance

2. Industrial Safety and Health

3. Industrial Relations

4. Apprenticeship

5. Building and Construction Safety Inspection Services.

\section{Agency: Washington Department of Licensing (WDOL)}

Statutory Authority: Chapter 43.24 RCW

The Washington Department of Licensing (WDOL) is responsible for the licensing of businesses that wish to operate in Washington State. Through calling the toll free number (1-800-5628203), information is available including location of the nearest local office. Local offices can provide interested parties with the needed forms.

\section{Agency: Washington Department of Natural Resources (WDNR) Statutory Authority: Chapter 43.30 RCW}

The Washington Department of Natural Resources (WDNR) is a regulatory and land management agency. RCW Section 79.01.096 gives WDNR the authority to lease state trust land for the purpose of energy exploration and power plant construction. The Division of Lands has been instructed to adopt rules and regulations for leasing state lands for energy exploration and development since December 1991.

\section{Agency: Washington Department of Trade and Economic Development (WDTED) Statutory Authority: Chapter 43.31 RCW}

Economic development is an essential public purpose which requires the active involvement of state government. The Washington Department of Trade and Economic Development (WDTED) exists to encourage the retention and expansion of existing businesses, to attract new businesses and industries, and to foster the formation of new businesses.

It is the policy of the state of Washington to encourage and promote an economic development program that provides sufficient employment opportunities for our current resident work force and those individuals who will enter the state's work force in the future. WDTED monitors and helps to ensure that traditional functions of state government such as transportation, infrastructure, education, taxation, regulations strengthen balanced growth of the economy consistent with the preservation of Washington's quality of life and environment. 


\section{Agency: Washington Department of Wildife (WDW) Statutory Authority: Chapter 77.04 RCW}

The Washington Department of Wildlife (WDW) is mandated by the legislature to ". . preserve, protect, and perpetuate wildlife. .." of Washington (RCW 77). These wildlife, which are property of the state, include wild animals, wild birds, and game fish. Policies set forth by the WDW state that, "The first management priority will be to establish and perpetuate the highest quality wildlife habitat."

WDW also has obligations under such federal laws as the Federal Power Act and Fish and Wildlife Coordination Act. These require developers to consult with state agencies to determine what conditions may be necessary for protection of fish and wildlife resources. The WDW commonly works together with other agencies, such as the Washington Department of Fisheries, National Marine Fisheries Service, U.S. Fish and Wildlife Service, and Indian tribes, to determine potential impacts and possible mitigation proposals.

Although each energy project is individually evaluated, some guiding principles are common. Replacement of losses in-kind and on-site is the objective of the WDW's mitigation and compensation efforts. Although this cannot be achieved exactly, it may be approached in several ways.

WDW works with project sponsors to ensure in advance that adequate measures to protect fish and wildlife are included in initial plans. Specific provisions are usually assumed by the project sponsor and must be incorporated into the cost/benefit analysis of the planning process.

WDW requires studies that will determine project-specific and cumulative impacts and identify mitigation and enhancement measures. On rivers where cumulative impacts are possible, delays may occur as studies are conducted. These studies are funded by project proponents, preferable under the direction and guidance of fish and wildlife agencies. WDW also advises project sponsors throughout the planning, development, and operational phases of the project.

\section{Agency: Washington Office of Archaeology and Historical Preservation (WOAHP) Statutory Authority: $27.34 .210 \mathrm{RCW}$}

The Washington Office of Archaeology and Historical Preservation (WOAHP) is responsible for ensuring that a proposed development site is not listed in the National Register of Historic Places. If it is listed, WOAHP will determine the number and extent of any resources and their scientific or cultural importance. Accordingly, plans and procedures will be outlined for impact mitigation.

\section{Agency: Washington Energy Facility Site Evaluation Council (WEFSEC) Statutory Authority: $80.50 .030 \mathrm{RCW}$}

The Washington Energy Facility Site Evaluation Council (WEFSEC) maintains siting jurisdiction over all lands, private and state owned, when an non-hydro energy facility (existing or pro- 
posed) exceeds $250 \mathrm{MW}$. It was created to provide a one-stop licensing agency for major energy projects. WEFSEC is responsible for coordinating the application processing through all state and local agencies which results in saving the energy developer both time and money.

Energy facilities under $250 \mathrm{MW}$ are regulated by the Departments of Natural Resources and the Washington Department of Ecology and possibly fall under local jurisdiction as well. Some consideration is being given to lowering the threshold for WEFSEC review to $50 \mathrm{MW}$, putting Washington more in line with regulations in Oregon and Montana.

\section{Agency: Washington State Energy Office (WSEO) Statutory Authority: 43.21F.035 RCW}

It is the policy of the Washington State Energy Office (WSEO) to promote the development and use of a diverse array of energy resources. The use and development of renewable energy resources are particularly encouraged provided that such projects are consistent with the statutory environmental policies of the state. In order to assist in the construction of environmentally acceptable and cost-effective renewable resource projects, the state energy office has established a renewable resource section within the agency. Renewable resource specialists assist potential developers through the state and federal leasing, licensing, and permitting processes, as well as provide technical assistance in the areas of financing, design, and overall project development.

\section{Agency: Washington Utilities and Transportation Commission (WUTC) Statutory Authority: $80 \mathrm{RCW}$}

The general duties of the Washington Utilities and Transportation Commission (WUTC) are to regulates electric companies, gas companies, irrigation companies, telecommunications companies, and water companies. Rates, services, facilities, and practices of all persons engaged in the business of supplying any utility service or commodity to the public for compensation are subject to the rules and regulations of the WUTC.

The WUTC regulates electric company purchases of electricity from Qualifying Facilities (QF) and Independent Power Producers and Purchases of electrical savings from conservation suppliers (Chapter 480-107 WAC et. seq.). They establish rules for determining rates, terms, and conditions governing purchases by electric utilities from QFs, the electrical savings associated with eligible conservation measures, electricity from Independent Power Producers, the competitive bid process for the acquisition of new electric resources by the Investor Owned Utilities (IOUs), and electric utilities. The rules are intended to provide an opportunity for conservation and generating resources to compete on a fair and reasonable basis to fulfill a utility's new resource needs. It is the WUTC's intent that bids under these rules include the costs of compliance by the project with environmental laws rules, and regulations in effect at the time of the bid and those reasonably anticipated to be in effect during the term of the project. 
Electric utilities may construct electric resources, operate conservation programs, purchase power through negotiated purchase contracts, and take action to satisfy their public service obligations.

The provisions of the chapter apply to any electric utility which has submitted to the commission a least-cost plan as provided in WAC 480-100-251. A "least-cost plan" means a plan describing the mix of generating resources and improvements in the efficient use of electricity that will meet current and future needs at the lowest cost to the utility and its rate payers.

Each electric utility regulated by the commission has the responsibility to meet its load with a least-cost mix of generating resources and improvements in the efficient use of electricity.

\section{State Permitting and Licensing Requirements}

Although numerous agencies have potential permitting or review authority, cogeneration facilities are likely to require only a few permits and/or licenses. Permits and/or licenses described in this section may not all apply to your particular project.

\section{Table 23}

\section{Do You Need a Permit? \\ Or do you need to notify authorities?}

Yes - if, for example...

You build a large plant for electrical power production (250 MW+)

You build a new structure

Your plant affects sensitive areas such as wetlands

Your process emits dust, smoke, or gases

You make changes to a plant that will result in changes in emissions

You burn garbage, or materials that may emit hazardous pollutants

You discharge wastes into state waters, or build a waste water treatment and/or disposal system

You dispose of sludge from an anaerobic digester, store

stillage from an alcohol plant, or incinerate sewage sludge

You manufacture, distribute, sell, or fumish gas to a user

Your plant contains a boiler or pressure vessel

You use surface water, or more than $5,000 \mathrm{gal} / \mathrm{day}$ of groundwater

You produce alcohol experimentally or for sale

\section{Reference}

WEFSEC

Local Building Department

CORPS \& local Planning Depart.

WDNR and/or WDOE, APCA

WDOE or APCA

WDOE or APCA

CORPS and WDOE

WDOE and LHD

WUTC

WDL\&I

WDOE

BATF
Legend:
APCA
BATF
CORPS
LHD
Local Air Pollution Control Authority
WDL\&I
WDNR
WDOE
WEFSEC
U.S. Bureau of Alcohol, Tobacco and Firearms
U.S. Army Corps of Engineers
Local Health Department
Washington Department of Labor and Industries
Washington Department of Natural Resources
Washington Department of Ecology
WUTC
Washington Energy Facility Sile Evaluation Council
Washington Utilities and Transportation Commission 


\section{Table 24}

Possible State Permits or Evaluation Required

for Development of a Cogeneration Project

\begin{tabular}{|c|c|c|c|c|}
\hline Permit & Agency & Comments & Appr & Time \\
\hline $\begin{array}{l}\text { State Environmental } \\
\text { Policy Act Compliance }\end{array}$ & $\begin{array}{l}\text { SEPA lead } \\
\text { agency }\end{array}$ & & None & $\begin{array}{l}3 \text { wks- } \\
3 \text { yrs }\end{array}$ \\
\hline $\begin{array}{l}\text { Pernit to Appropriate } \\
\text { Public Waters } \\
\text { (Water Right) }\end{array}$ & WDOE & $\begin{array}{l}\text { Required for any use of water for cogeneration } \\
\text { generation. Permit must be obtained prior } \\
\text { to construction. I some cases an existing } \\
\text { right may be changed to energy use } \\
\text { upon approval by WDOE. }\end{array}$ & $\begin{array}{l}\text { Examination fees } \$ 10 \\
\text { minimum, or for each } \\
\text { cfs appropriated: } \\
1-500-\$ 2 / \mathrm{cfs} \\
500-2,000-50 \notin / \mathrm{cfs} \\
2,000+-20 \AA / \mathrm{cfs} \\
\text { Other fees may apply. } \\
\text { Contact any WDOK office } \\
\text { to see RCW } 90 / 03.470\end{array}$ & $\begin{array}{l}18-24 \\
\text { mos. }\end{array}$ \\
\hline $\begin{array}{l}\text { Water Quality } \\
\text { Certification }\end{array}$ & WDOE & $\begin{array}{l}\text { Required before a federal license or } \\
\text { permit is issued. }\end{array}$ & None & $\begin{array}{l}2 \text { mos. } \\
1 \text { yr. }\end{array}$ \\
\hline $\begin{array}{l}\text { Short-term Modification } \\
\text { to Water Quality Standards }\end{array}$ & WDOE & $\begin{array}{l}\text { Required for any activity that will result } \\
\text { in temporary violation of state water } \\
\text { quality standards (Chap. 173-201 WAC). }\end{array}$ & None & 2 mos. \\
\hline $\begin{array}{l}\text { Flood Control Zone } \\
\text { Permit }\end{array}$ & WDOE & $\begin{array}{l}\text { Required if project is located in designated } \\
\text { flood control zone. }\end{array}$ & None & 1 mos. \\
\hline $\begin{array}{l}\text { NPDES and/or State } \\
\text { Waste Discharge } \\
\text { Permit }\end{array}$ & WDOE & $\begin{array}{l}\text { Needed if pollutants, including energy fluid } \\
\text { will be discharged into surface or ground waters. } \\
\text { May not be required for heat pump applications. } \\
\text { May be required if project includes sewage } \\
\text { treatment or disposal system. }\end{array}$ & Approx. $\$ 1,000$ & $2-6$ mos. \\
\hline $\begin{array}{l}\text { Annual Power Production } \\
\text { License Fee }\end{array}$ & WDOE & $\begin{array}{l}\text { Assessed at the beginning of every year. } \\
\text { Based on theoretical horsepower. Less } \\
\text { than } 50 \mathrm{hp} \text { exempt. }\end{array}$ & $\begin{array}{l}\text { o-50hp-exempt } \\
50-1,000-10 \mathrm{kp} \\
+1,000-10,000-2 \notin / \mathrm{hp} \\
+10,000-1 \mathrm{c} / \mathrm{hp}\end{array}$ & \\
\hline $\begin{array}{l}\text { Public Water } \\
\text { Supply Approval }\end{array}$ & WDOH & $\begin{array}{l}\text { Required if public drinking water supply } \\
\text { is needed or altered. }\end{array}$ & $\begin{array}{l}\text { Based on size of } \\
\text { proposed system. }\end{array}$ & 3 mos. \\
\hline $\begin{array}{l}\text { Archaeological } \\
\text { Approval }\end{array}$ & WOAHP & $\begin{array}{l}\text { The National Historic Preservation Act } \\
\text { required that WOAHP be contacted prior } \\
\text { to development. }\end{array}$ & No set standard. & 2 mos. \\
\hline Forest Practices Approval & WDNR & For construction on forested, nonfederal land. & None & 5-30 days \\
\hline Buming Permit & WDNR & To burn wood and debris & None & I wk \\
\hline Dumping Permit & WDNR & $\begin{array}{l}\text { Dumping } 750 \text { cu.yds. of land clearing debris } \\
\text { on nonfederal land. }\end{array}$ & None & 1 wk \\
\hline $\begin{array}{l}\text { Easement to Use State } \\
\text { Lands }\end{array}$ & WDNR & Facilities, transmission lines on state lands. & Fair market value & 4 mos. \\
\hline $\begin{array}{l}\text { Right of Way or Road } \\
\text { Uses }\end{array}$ & WDNR & For easements to cross state lands. & \$ & $2+\operatorname{mos}$ \\
\hline $\begin{array}{l}\text { Application to Purchase } \\
\text { Valuable Material }\end{array}$ & WDNR & $\begin{array}{l}\text { Covers excavation and use of any stone, rock, } \\
\text { sand, gravel, or silt from stafe lands. }\end{array}$ & Fair market value. & $2+\operatorname{mos}$ \\
\hline $\begin{array}{l}\text { Permit to Temporanily } \\
\text { Remove or Destroy Survey } \\
\text { Monument. }\end{array}$ & WDNR & $\begin{array}{l}\text { Removal or destruction of any section comer } \\
\text { or other land boundary mark or monument. }\end{array}$ & None & I wk. \\
\hline $\begin{array}{l}\text { Special Motor Vehicle } \\
\text { Permit }\end{array}$ & WDOT & For any overweight or oversized vehicle. & None & 1 day \\
\hline $\begin{array}{l}\text { New Source } \\
\text { Construction } \\
\text { Approval }\end{array}$ & $\begin{array}{l}\text { Local Air Pollu- } \\
\text { tion Control } \\
\text { Auth. or WDOE } \\
\text { for certain counties }\end{array}$ & $\begin{array}{l}\text { For dust control during use of construction } \\
\text { machines such as concrete batch plants and } \\
\text { asphalt plants. }\end{array}$ & $\begin{array}{l}\text { Varies with individual } \\
\text { air authorities. }\end{array}$ & 1-2 mos. \\
\hline
\end{tabular}

NOTE: Most projects will not require all of the permits listed. Small projects are likely to require only a few of those permits.

*See additional information on the individual permit.

cfs - cubic feet per second

hp - horsepower 


\section{Air Quality}

Air pollution control in Washington is based on a set of local, state, and federal laws and regulations involving three levels of government. The federal government, through the Environmental Protection Agency (EPA), sets air pollution standards that apply nationally. The state government, through the Washington Department of Ecology (WDOE) and, in some cases, the Washington Energy Facility Site Evaluation Council (WEFSEC), is required to implement those standards. A third level of government, local air pollution control agencies, also has broad responsibilities for implementing air pollution control activities within their single or multi-county jurisdictions. Jurisdictional boundaries of the state's nine local air pollution control agencies and addresses and telephone numbers for air quality contacts can be found in Appendix 1E.

WDOE implements and enforces several air regulations. The local air authorities implement and enforce most state regulations, and some local agencies have additional regulations that are more restrictive than those of WDOE. These additional or more stringent regulations are not addressed in this guide.

WDOE has jurisdiction over all sources located in counties that do not have activated local authorities. Additionally, WDOE has assumed jurisdiction over primary aluminum plants, pulp mills, vehicles, and vehicle-related sources.

Large new energy related resources, such as thermal plants greater than $250 \mathrm{MWe}$, are under the jurisdiction of WEFSEC.

Permit or Regulation: Air Contaminant Source Registration

Statutory Authority: $R C W$ 70.94; 173-400 WAC

Agency: Washington Department of Ecology (WDOE)

Air contaminant sources in Washington State must be registered. Air contaminant source registration classifies the levels and types of air emissions. Registration is done through the Washington Department of Ecology (WDOE).

Permit or Regulation: Air Pollution Standards Variance

Statutory Authority: RCW 70.94; 173-400 WAC

Agency: Washington Department of Ecology (WDOE)

An air pollution standards variance is issued for temporary variances from air pollution standards. The Washington Department of Ecology (WDOE) issues this variance. 
Permit or Regulation: New Source Construction Approval

Statutory Authority: RCW 43.21A, 70.94; 173-400, 173-405, 173-410, 173-415, and 173-490 WAC

Agency: Washington Department of Ecology (WDOE) or Air Pollution Control Authority (APCA)

The Washington Department of Ecology (WDOE) or the local air pollution control authority (APCA) has review and approval authority over new source construction and/or additions to existing sources releasing contaminants into the ambient air. This permit requires the listing of all source units (not including mobile equipment on the site for less than 60 days), each type of air pollution generating equipment used, air pollution control equipment, and the type and amounts of pollutants produced. Two sets of plans are required with information on the equipment and control apparatus, plot plan, and the proposed means of air contaminant control or prevention.

Approval is required for construction, installation, or establishment of a new stationary source of emissions. Within 30 days of receipt of a Notice of Construction (NOC), the reviewing authority (local Air Pollution Control Authority [APCA]), WDOE regional offices, or Washington Energy Facility Site Evaluation Council (WEFSEC) may require additional information of the applicant.

Within 30 days of receiving all required information, the reviewing authority will make a preliminary determination. This determination will be made available in at least one location in the county(s) where the project is to be located.

The applicant must publish a notice informing the public of the opportunity to provide written comment on the preliminary determination within $\mathbf{3 0}$ days of published notice.

After review of all current information, the reviewing authority issues either an order denying construction or an order of approval for construction. An order of approval may contain specific requirements and conditions. The opportunity for public hearing is necessary for proposed construction where offsetting is proposed.

WDOE Environmental Permit Information Center (EPIC) (206-459-6022) can refer applicants to specific air pollution control authorities in their area.

The Washington Department of Health (WDOH) reviews and approves plans and specifications for on-site sewage systems with design flows, at any common point, between 3,500 gallons/day and 14,500 gallons/day. Local health departments can take on this responsibility with a contractual agreement with WDOH.

WDOE reviews and approves plans and specifications for on-site systems exceeding 14,500 gallons/day, all systems receiving state or federal construction grants under the Clean Water Act 
and systems using mechanical treatment or lagoons with ultimate design flows above 3,500 gallons/day. WDOE regulations generally require public ownership, operation and maintenance of domestic waste water facilities.

Approximate Time Required to Obtain Approval

This approval process will take from 1 to 2 months total.

Permit or Regulation: Prevention of Significant Deterioration (PSD)

Statutory Authority: RCW 43.21A; 173-400 WAC Agency: Washington Department of Ecology (WDOE)

The basic objective of the Prevention of Significant Deterioration (PSD) program is to prevent substantial degradation of air quality in areas that are in compliance with national ambient air quality standards, while maintaining a margin for future industrial growth. Each proposed new or modified air contaminant source must undergo a new source review. As part of this review, PSD applicability is determined. If PSD review is required, a PSD application must be submitted and a permit obtained before beginning project construction.

Criteria that trigger PSD vary depending on the type and amount of air contaminant(s) emitted, type of facility, and the proximity of a project to a designated Class I area. Generally, PSD review is not required for facilities that emit less than 100 tons per year of a regulated pollutant.

Specific information on PSD requirements can be found in the Code of Federal Regulations (CFR) 40 CFR 52.21, as adopted and supplemented by state statute. However, this regulation is quite complex, so it is best to contact the appropriate air authority to determine if your proposal will require $P S D$ review.

\section{Permit or Regulation: Sensitive Areas}

Statutory Authority: RCW 70.94; 173-400 WAC Agency: Washington Department of Ecology (WDOE)

Certain geographic areas within Washington State are designated as air quality Sensitive Areas after considering population, development, and recreational and scenic values. When located in Sensitive Areas, certain stationary source categories (specified by regulation) may be subject to more stringent standards and compliance requirements.

\section{Land Use}

The Washington Department of Natural Resources (WDNR), under the direction of the Commissioner of Public Lands, administers many permits regulating the use of over 12.5 million acres of state and private land. Forest practices enforcement, surface mine regulation, and administration of other land resource permits, are among the WDNR's responsibilities. The Washington De- 
partment of Community Development (WDCD) and the Washington Office of Archaeology and Historic Prevention (WOAHP) are charged with protecting historic and archaeological resources in the state.

WDNR has also established a policy concerning awarding right-of-way over state trust lands for the purpose of constructing roads or transmission inter ties. RCW sections 79.01.384 and 79.01.388 allow the state to grant rights-of-way to municipalities, private corporations, associations, or individuals for the purpose of constructing ditches, flumes, pipelines, or transmission lines in order to generate or transmit electricity. The applicant is required to complete a survey of the involved land and append plats to an Application for Right-of-Way or Road Use Permit Over Lands. WDNR may charge a one-time payment for permanent development rights that is based upon the fair market value of the land involved, or may require a base annual rental plus a percentage of gross income.

\section{Permit or Regulation: Application to Purchase Valuable Material Statutory Authority: RCW 79.01.124 and 79.01.132 Agency: Washington Department of Natural Resources (WDNR)}

A standard application form can be obtained from the Washington Department of Natural Resources (WDNR). It will evaluate the fair market value for a purchase price. The legal location of the pit or quarry, excavation method proposed, the location of any timber stands or state quarries, the proposed excavation time, the planned use of the material, and the reclamation plan should also be provided with the application. SEPA compliance is required prior to issuance.

Approximate Time Required to Obtain Approval

It will take at least 2 months to receive this permit.

\section{Permit or Regulation: Archaeological Approval \\ Statutory Authority: Executive Order 11593 \\ Agency: Washington Office of Archaeology and Historic Preservation (WOAHP)}

The Washington Office of Archaeology and Historic Preservation (WOAHP) should be contacted prior to the start of a project. A historic/archaeological assessment may be required at the project site. The status of any sites or structures that are listed for the National Register of historic places will be identified. The number and extent of any resources that are present and their scientific importance will be determined. Plans and procedures will be outlined for recovery or mitigation of adverse effects. This approval is required prior to obtaining federal permits or licenses and SEPA approval.

Approximate Time Required to Obtain Approval

Approval should be received in 2 months. 
Permit or Regulation: Archaeological Excavation

Statutory Authority: RCW 27.44, 27.53; 25-48 WAC

Agency: Washington Department of Community Development (WDCD), Washington Office of Archaeology and Historic Preservation (WOAHP)

The Washington Department of Community Development (WDCD), Washington Office of Archaeology and Historic Preservation (WOAHP) should be contacted prior to the start of the project to determine if historic or archaeological sites will be affected. A historic/archaeological excavation assessment may be required. A permit from WDCD, WOAHP, must be obtained prior to any excavation that will alter or remove Native Indian grave site or archaeological resources.

The status of any sites or structures listed in or eligible for the State or National Register of Historic Places or Local Landmark designation may need to be determined. Plans for protection of mitigation measures may be a condition of any permit issued.

\section{Permit or Regulation: Dumping Permit}

Statutory Authority: $R C W$ 76.04.242

Agency: Washington Department of Natural Resources (WDNR)

After a dumping area has been established, the Washington Department of Natural Resources (WDNR) is contacted and an inspector sent; the permit will be issued at the site. The inspector should be provided with a description of the dumping location and information regarding dumping practices and fire safety precautions.

Approximate Time Required to Obtain Permit

This permit can be obtained in 1 week.

\section{Permit or Regulation: Energy Facility Site Evaluation}

Statutory Authority: 80.50 RCW; 463 WAC

Agency: Washington Energy Facility Site Evaluation Council (WEFSEC)

The Washington Energy Facility Site Evaluation Council (WEFSEC) and the certification process (licensing) for siting, construction, and operation of major energy facilities is to ensure through available and reasonable methods, that the location and operation of major energy facilities will produce minimal adverse effect on the environment, ecology of the land and its wildlife, and the ecology of the state waters and their aquatic life.

WEFSEC is a Washington State agency comprised of a chairman appointed by the Governor and representatives from 13 state agencies. WEFSEC is augmented by representatives from particular cities, counties, or port districts potentially affected by a project. WEFSEC was created to provide a one-stop licensing agency for major non-hydro energy projects. 
WEFSEC is the only state agency to which an application to construct and operate a major energy facility may be filed. After WEFSEC reviews an application, it makes a recommendation to the Governor. The Governor is the final decision maker for approval or disapproval of the application.

For projects reviewed by WEFSEC, approved by the Governor, and granted a license to construct and operate, WEFSEC then regulates the construction and operation of the plant in accord with conditions of the license. WEFSEC fulfills its regulatory function through contracts with state agencies having the expertise to monitor and evaluate each aspect of the project. EFSEC has the authority to fine the owner or stop construction or operation if licensing conditions are not met. WEFSEC continues this oversight responsibility through site restoration after termination of the project.

To accomplish its work, WEFSEC meets regularly to discuss major issues at hand. An Executive Committee provides administration and sets WEFSEC agendas. Ad hoc technical review subcommittees may be formed for individual projects or review of special items of interest. The Washington State Energy Office (WSEO) provides staff to WEFSEC.

It is strongly recommended that prospective applicants meet with WEFSEC well in advance of submitting an application. The WEFSEC process is very open but structured. Applications for major energy facilities must be complete and thorough before they can proceed through the process. Early meetings with WEFSEC will help applicants understand what will be necessary and desirable for a specific project.

The WEFSEC certification process (Figure 11) was designed to give the applicant and others an opportunity to express their proposal and concems to WEFSEC, and for WEFSEC to address interests which have bearing on matters arising from the application.

The certification process may start in one of two ways. First, an applicant may apply to WEFSEC to begin the process or second, an applicant may want to have WEFSEC conduct a Potential Site Study before applying for a Site Certification Agreement (SCA). Because of the costs involved in preparing a full application, a Potential Site Study offers the benefit of determining if there are any environmental, social, or regulatory "hurdles" that can't be overcome. This can result in great savings of time and expense.

\section{WEFSEC Certification}

WEFSEC certification is the state licensing procedure for the construction and operation of an energy project. After WEFSEC review and approval by the Governor, a Site Certification Agreement (SCA) listing the construction and operational conditions the applicant must meet is signed by both the applicant and the Governor. There are four major steps in the certification process:

1. the application

2. application review
3. adjudicative proceedings

4. recommendation to the Governor. 


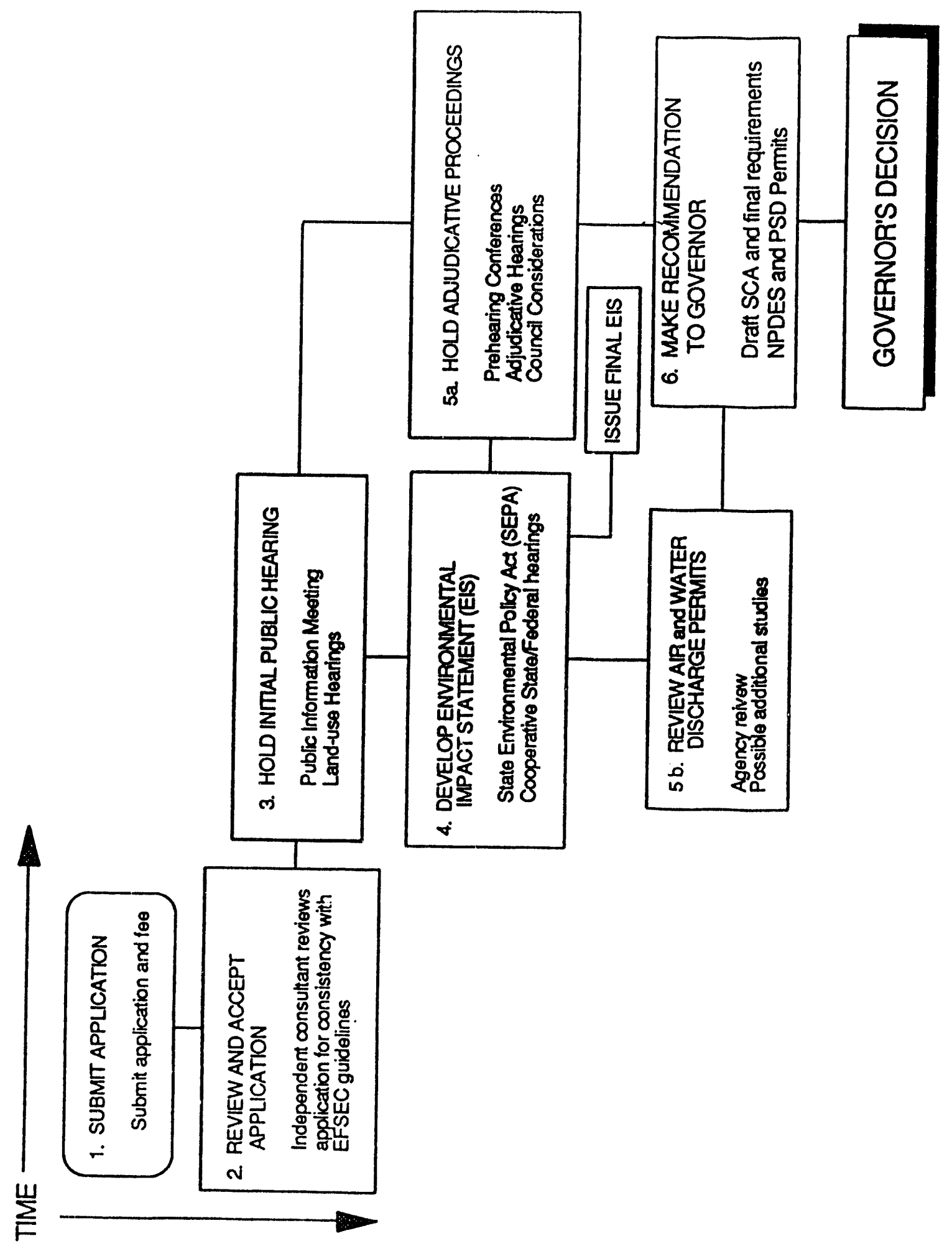

Figure 11: WEFSEC Certification Process 
Each step has specific requirements that the applicant and the WEFSEC must follow. The requirements provide for a comprehensive and balanced review of the project.

The major energy facilities subject to the WEFSEC are:

- any stationary thermal (non-hydro) power plant with electrical generating capacity of $250 \mathrm{MW}(250,000 \mathrm{~kW})$ or more including their associated facilities such as transmission lines in excess of 200,000 volts

- $\quad$ natural gas, synthetic fuel, gas, or liquefied petroleum gas pipelines larger than 14 inches and lengths of greater than 15 miles

- liquid natural gas facilities with capacity to receive equivalent of more than $100,000,000 \mathrm{cu} . \mathrm{ft} . / \mathrm{day}$ which has been transported over marine waters

- crude or refined petroleum or liquefied petroleum facilities that can receive more than an average of 50,000 barrels/day which will be or have been transported over marine waters (this won't apply to storage facilities unless they are part of a new energy plant or transmission facility).

\section{Potential Site Study}

Anyone considering developing an energy facility may, before applying for a SCA, request WEFSEC conduct a fatal flaw analysis of the proposed site. The Potential Site Study is an option that allows the developer to request that WEFSEC determine the environmental and socioeconomic feasibility of a project. A request should, at a minimum, include a legal description of the area in which the proposed facility is to be located and a complete description of the type, size, and significant features of the proposed facility. Additional information may be requested by WEFSEC.

After receiving a request to study a potential site, WEFSEC will commission an independent consultant to prepare a study relative to the potential site. The study can include but need not be limited to, the preparation and analysis of environmental impact information for the proposed potential site and any other matter WEFSEC and the applicant deem essential for an adequate appraisal. In conducting the study, WEFSEC is authorized to cooperate and work jointly with the county or counties in which the site is located, any federal, state, or local governmental agency that might be requested to comment upon the potential site, and any municipal or public corporation having an interest in the matter.

WEFSEC requires a fee of $\$ 10,000$ to accompany a request for a potential site study. If WEFSEC finds that $\$ 10,000$ will not sufficiently cover the costs of the study, WEFSEC will advise the applicant and request additional funds. The study will not be continued if the applicant does not agree to pay the additional costs. 
If the findings of the fatal flaw analysis reveal there are no major environmental, social, or regulatory problems, the applicant can continue with an application to WEFSEC for the license to construct and operate the energy facility. Because the Potential Site Study is not a requirement for certification, a developer should determine the economic benefits regarding the timing of an application or Potential Site Study in relationship to the development schedule for the project.

\section{Application}

There are no specific application forms except as may be otherwise approved by WEFSEC in negotiations with a potential applicant. An application should contain a letter of submittal, the application fee, and a completed document which contains the information required in WEFSEC rules (Chapter 463-42 WAC, Procedure-Guideline-Application for Site Certification).

There are two ways an application can proceed through the WEFSEC application process. The standard WEFSEC process requires WEFSEC to submit a recommendation to the Governor within 1 year of the date of application (unless it is mutually agreed by the applicant and WEFSEC that more time is needed). The second is an Expedited Process in which WEFSEC is required to make a determination of eligibility within 4 months of application submittal and give its recommendation to the Governor within 6 weeks of granting eligibility. However, to gain eligibility for expedited processing, the application must meet certain conditions.

\section{Expedited Process}

The expedited process request requires an WEFSEC determination of eligibility:

- consistency with existing local land use ordinances

- extent of environmental impact of the area potentially affected

- cosi id magnitude of the project

- deg : of change in use of the proposed site.

An application for expedited processing must address all the matters that are required by the Council Rules in Chapter 463-42 WAC.

A fee of $\$ 25,000$ is required for each application to be used by WEFSEC for processing. If processing costs exceed the application fee, WEFSEC may charge for all reasonable and appropriate work for processing each application. WEFSEC would return the unused portion of the fee if costs were less than $\$ 25,000$.

Following a review of an application and a land-use hearing, WEFSEC will make a determination within 120 days of the application date (or later if mutually agreed by WEFSEC and applicant) that the application qualifies for expedited processing. If WEFSEC determines and grants expedited processing, WEFSEC will not have an independent consultant review the application or hold adjudicative hearings. WEFSEC will prescribe the form, content, and necessary supporting documentation for site certification. All persons and the Counsel for the Environment will have an opportunity to make presentations before WEFSEC. 
In spite of expedited processing, any facility with air emissions requiring a Prevention of Significant Deterioration (PSD) permit or water discharges requiring a National Pollutant Discharge Elimination System (NPDES) permit would need to be processed according to WEFSEC rules regarding these permits. These permits would require public notification and public hearings. To process these permits within the expedited processing time limitations, the applicant would need to file with the application all emission data, air shed and water quality studies, and supporting information necessary to demonstrate the ability to comply with state standards for air or water emissions.

Within 60 days of the granting of expedited processing, WEFSEC will submit its recommendation to the Governor with a draft Site Certification Agreement.

WEFSEC's determination of environmental significance of a project under a SEPA review could be a controlling factor for determining expedited processing eligibility. Most projects that fall under WEFSEC authority would most likely not be eligible for expedited processing due to the environmental impacts of the projects.

\section{Standard Process}

An application must contain and be organized in the manner set in Chapter 463-42 WAC (section on Laws and Rules). All of the more than 60 subjects must be fully developed and addressed in the application.

The application is the document that provides the details necessary for WEFSEC to develop an Environmental Impact Statement (EIS). The application is also the document that commits the developer to construct and operate the facility in an environmentally safe manner and to abide by the rules and regulations which WEFSEC will use to monitor and check for compliance with state laws.

\section{Application Review}

WEFSEC requires a fee of $\$ 25,000$ with each application. This fee is applied toward the cost of an independent consultant who will evaluate the application for adequacy and, in many cases, develop an Environmental Statement for WEFSEC based on the information contained in the application. The applicant must also pay for all reasonable costs for WEFSEC processing of the application. Costs may include the salary of an administrative law judge who may be retained for any portion of the application process, a court reporter for developing transcripts of the adjudicatory proceeding, WEFSEC meetings or public sessions, staff salaries for processing the application, and overhead and supporting administrative costs.

Total cost of processing an application will depend on the complexity of and opposition to a project. The more complex a proposal, the more time and effort is necessary to process it. Possible additional environmental studies, consultants fees, EIS preparation, and staff time could be necessary if all concerns are not met by the initial application. 


\section{Environmental Impact}

State Environmental Policy Act (SEPA) and Environmental Impact Statement (EIS)

Upon receiving an application, the Washington Energy Facility Site Evaluation Council (WEFSEC) will determine if the proposal is an "action" and, if so, whether it is "categorically exempt" from State Environmental Policy Act (SEPA). If the proposal is an action and not exempt from SEPA, WEFSEC will request the applicant complete an environmental checklist. (A checklist is not needed if WEFSEC and applicant agree that an Environmental Impact Statement is required.) The applicant may also submit an environmental checklist with its application.

If agreed, WEFSEC will prepare, print, and distribute an EIS. If WEFSEC is unable to prepare an EIS, WEFSEC will retain a mutually agreed upon independent consultant to prepare the document. The applicant will bear the expense of the EIS preparation, but the consultant will work for WEFSEC. WEFSEC can require the applicant to provide additional information which may require the applicant to conduct specific investigations.

WEFSEC will coordinate with other governmental agencies in the preparation of joint Environmental Statements. If has, in the past, co-authored EIS's with federal agencies thus reducing duplication of effort. In each case, WEFSEC maintains lead agency status.

An estimate of 9-12 months can be expected for the development of an EIS (see The Federal Process, Preparing Environmental Statements). Time to develop the EIS depends on:

- the length of time required to develop a Memorandum of Understanding between the state and federal agencies to define the roles of each agency in developing the environmental document

- issuance and length of contracts for EIS development

- completeness of the information contained in the application

- scoping meetings

- need for additional data or studies

- development and finalization of draft and final documents.

Costs for development of an EIS could range from an estimated $\$ 100,000$ to $\$ 250,000$, depending on the complexity of the project. An EIS for siting a cogeneration facility in an area which has already been extensively studied or has substantial industrial development may cost substantially less than a gas pipeline traversing a portion of the state. Potential Site Studies and environmental studies completed prior to development of an EIS are usually initiated by the developer of a facility. The developer usually works closely with WEFSEC and its contractor to develop an EIS using information and data supplied by the developer.

The draft EIS will be subjected to public notice and review. WEFSEC may hold public hearings on the draft EIS. 
The timing of the development of the EIS and related public hearings on the draft EIS may be parallel with the adjudicative proceedings. However, the adjudicative proceedings must be finalized before WEFSEC issues the final EIS.

\section{Initial Public Hearing}

The initial public hearing will be used to explain the proposed project and the EFSEC process. It will be held in the vicinity of the proposed project after notification of public officials, publication of notices, and news releases. The public hearing usually will be conducted in two parts.

\section{Land Use Hearing}

WEFSEC will hold a Land Use Hearing to ascertain if the proposed project is consistent with county or regional land use plans or ordinances. Testimony or certification of consistency with county or regional land use plans will be accepted during this hearing. Testimony will be allowed by anyone wishing to address WEFSEC regarding consistency with land use plans.

Most cities require some sort of special use permit or only permit energy facilities in industrial zones.

Counties typically do not have zoning requirements for energy facilities that WEFSEC would regulate, but some counties may develop requirements for cogenerators of electricity.

If WEFSEC determines the project is not consistent with local land use plans, the applicant can apply to the local agency for a variance (463-28-030 WAC) to the plan or ordinance. If a variance cannot be obtained, the applicant can request state preemption under 463-28-020 WAC. The request shall address items outlined in 463-28-040 WAC. WEFSEC shall determine if preemption should be recommended to the Governor.

\section{Public Information Meeting}

The Public Information Meeting will allow the applicant to describe the proposed project. WEFSEC will describe the WEFSEC process for reviewing and determining the recommendation it will make to the Governor regarding the application. WEFSEC will also allow the public to present written or oral testimony relating to the proposed project, but the testimony will not be part of the adjudicatory proceedings.

\section{Adjudicative Proceedings}

The WEFSEC Adjudicatory Proceeding is a quasi-judicial process similar to courtroom proceedings where WEFSEC hears both parties to the proceedings. All state agencies having members on WEFSEC are deemed to be parties to any adjudicatory proceeding before WEFSEC. If the agencies wish to be active participants in the proceedings, the agency's Assistant Attorney Gen- 
eral will represent the agency during the proceedings. A Counsel for the Environment will be appointed by the state Attorney General's Office to represent the public and its interest in protecting the quality of the environment.

Other interested parties or persons may petition WEFSEC to become interveners in the proceedings. WEFSEC will consider the petitions and issue administrative orders regarding their findings. Parties and petitioners may ask WEFSEC for administrative review if they disagree with WEFSEC's decision on intervener status.

WEFSEC may conduct the hearings or may utilize an Administrative Law Judge provided by the state Office oi Administrative Hearings. Representatives of the county or counties, city, or port district will be appointed to WEFSEC for the duration of the proceedings. All but port district representatives will be voting members.

As stated, adjudicatory proceeding will be conducted in a quasi-judicial manner. Parties and interveners are recommended to have legal counsel represent them during the hearings. All orders, notices, and papers must be served on all parties with proof of service.

The hearings will be conducted pursuant to Chapter $34.05 \mathrm{RCW}$, the state's Administrative Procedures Act.

\section{Air and Water Discharge Parmits}

In tandem with the Adjudicative Proceedings discussed above, WEFSEC will initiate its process for developing air and water discharge permits if needed.

Discharges to the air may require the applicant to receive a Prevention of Significant Deterioration (PSD) permit. Issuance of the PSD has been delegated to WEFSEC by the Environmental Protection Agency (EPA). The EPA has also granted WEFSEC the authority to issue the National Pollutant Discharge Elimination System (NPDES) permit for discharging wastes in the state's water. WEFSEC has specific rules concerning requirements in obtaining these permits.

The permits will specify the level of contaminants the facility can discharge. Air quality standards are set in Chapter 463-39 WAC. This chapter will, ir most cases, reference WDOE standards set in Chapters 173-400 and 173-403 WAC. Water quality standards referenced by WEFSEC are in Chapter 173-201 WAC.

\section{Pre-hearing Conference}

Prior to any proceedings, a pre-hearing conference(s) will be held. The primary purpose of the pre-hearing conference is to define, focus, and narrow the issues as much as possible. WEFSEC or a hearings of nicer will use these conferences to determine what contested issues will be heard during the adjudicative hearings, the order of issues to be heard, and a schedule for the hearings. 
The pre-hearing conferences will also consider:

- the necessity of amendment(s) to the pleading

- the possibility of obtaining stipulations, admissions of facts, or documents

- the limitation on the number of expert witnesses

- other matters which may aid in disposition of the proceedings, including scheduling of the hearing and determination of sequence of the subject matter.

WEFSEC will make an order reciting action taken during any informal consultation, amendment to pleading, or stipulations.

\section{Hearings}

The hearings will provide an opportunity for the parties to cross examine each other and for WEFSEC to ask questions of parties. At the conclusion of the hearings, WEFSEC will adopt a proposed order and distribute it to the parties. Parties may take exception to the proposed order and parties may reply to the exceptions.

Upon consideration of the proposed order, exceptions, and replies to exceptions, WEFSEC will enter a final order, including findings of fact, conclusions of law, and recommendation to the Governor.

The length of the hearings depends on the complexity of the project and how controversial it may be. If the project is complex and impacts many aspects of the environment, several hearings may be required to address all aspects and sides of the issues. During the pre-hearing conferences specific issues will be identified. Each of these issues may be held separately and each hearing could last several days if there is extensive cross-examination.

To shorten the hearing process, WEFSEC may require submission of testimony prior to the hearing and permit only cross examination during the hearing. The separation of subject matter during the pre-hearing conferences also helps to isolate specific issues so the hearings wouldn't become bogged down.

WEFSEC endorses the concept of joint hearings as a means to save time and money; however, there are no rules that require joint hearings be held with other participating agencies. Joint hearings are often held with federal agencies requiring hearings on the siting and environmental aspects of a project as part of their regulatory role.

After the conclusion of hearings, WEFSEC will consider information heard or received as part of the adjudicative proceedings. It will then develop a final order and conclusion of law. If WEFSEC concludes the project should be recommended to the Governor, it will develop a draft Site Certification Agreement (SCA). The SCA will contain conditions the applicant must meet for construction and operation of the project and it will include any PSD or NPDES permits as attachnients. 
If WEFSEC finds that the project should not be recommended to the Governor, the final order will include reasons for WEFSEC's decision.

\section{Recommendation to the Governor}

A final order containing a recommendation to the Governor to approve the application will include a draft Site Certification Agreement (with PSD and NPDES permits as attachments) for the Governor's consideration. The Governor has 60 days to consider WEFSEC's recommendation and can take one of the following actions:

- approve the WEFSEC recommendation and execute the draft SCA

- reject the application

- direct WEFSEC to reconsider certain aspects of the draft SCA.

\section{Permit or Regulation: Environmental Coordination Procedures Act (ECPA) Statutory Authority: $90.62 \mathrm{RCW} ; 173-08 \mathrm{WAC}$ Agency: Washington Department of Ecology (WDOE)}

To coordinate permit procedures, the Environmental Coordination Procedures Act (ECPA) was adopted by the Washington State Legislature in 1973. This process gives you the option of submitting a Master Application form to assist in obtaining necessary permits for a project.

\section{Permit or Regulation: Forest Practices Approval \\ Statutory Authority: $R C W$ 76.09.060; 222 WAC Agency: Washington Department of Natural Resources (WDNR)}

This approval is required of the bona fide owner/operator of land before beginning any forest practice (harvesting, reforestation, road construction, etc.

Information is required on the location of the construction activities, the borrow and disposal areas, the construction methods and equipment, the size of needed rights-of-way, the restoration plans, the drainage plans, and an evaluation of the wildlife habitat to be removed.

Depending on the class of forest practice involved (see WAC 222-16-050), this permit may be contingent on the granting of Hydraulic Project Approval, Shoreline Substantial Development permit, Water Quality Certification, and SEPA compliance.

Approximate Time Required to Obtain Approval

It will take 5 to 30 days to receive this approval. 
Permit or Regulation: Right-of-Way or Road Use

Statutory Authority: $R C W$ 79.01.384, 79.01.388

Agency: Washington Department of Natural Resources (WDNR)

Applications for the right to use state lands are available at the Washington Department of Natural Resources (WDNR) headquarters or the local regional office. A separate application must be filed for each easement. The fair market value of any timber cut will be assessed and any costs incurred for a timber sale will be charged to the applicant.

Plans and sketches showing the location and design of all new construction must be submitted. Also needed are the locations, on plats, of new construction, a description of the engineering involved, and a description of the environmental impacts. SEPA compliance is required prior to issuance.

Approximate Time Required to Obtain Permit

It will take at least 2 months to obtain this permit.

\section{Permit or Regulation: Section 106 Review}

Statutory Authority: 36 CFR 800

Agency: Washington Department of Community Development (WDCD), Washington Office of Archaeology and Historic Preservation (WOAHP)

State and federal law protects historical and archaeological sites as well as National Register properties. The Washington Office of Archaeology and Historic Preservation (WOAHP) has responsibility for reviewing the impacts of proposed projects and any avoidance, mitigation, or protective measures proposed by the applicant. A report on the cultural resources located in the project area must be included in the license or exemption application. Assistance in preparing this report can be obtained from the WOAHP.

\section{Procedures for Review of Federal Projects}

After receiving a notification of a project, the WOAHP will check inventory and survey records to determine if surveys have been conducted and whether archaeological sites or historic properties have been identified in the project area.

Based on the nature of the project and on the project's location, the WOAHP will usually make one of the following comments (these comments technically are addressed to the federal agency, even though in some cases the federal agency requires private individuals to obtain WOAHP comments):

- Archaeological and historic surveys have determined there are no archaeological or historic properties in the proposed area. The project will have no effect.

- Based on the nature of the project and its location, it is unlikely the project will affect archaeological or historic properties. However, if archaeological materials (arrow points, bottles, etc.) are found during construction, the WOAHP should be contacted. 
- Based on the nature of the project and its location, it is likely, but not confirmed, that National Register properties occur in the project area and could be affected by the project. The agency should have the area inspected by a professional archaeologist, historian, or architectural historian, as appropriate, to locate and evaluate any archaeological sites and historic properties in the area. This work should follow the Secretary of Interior's guidelines for historic preservation projects.

- There has been a survey in the area, and archaeological sites or historic properties have been recorded. Following National Park Service standards, the agency should determine which sites or properties are eligible for the National Register.

- National Register properties will be adversely affected by the project, and the agency should obtain the comments of the Advisory Council on Historic Preservation.

In some cases, professionals from the WOAHP will inspect a project area to help a private firm or individual comply with federal preservation laws. If a project requiring federal approval or a federal license is not on federal land, is not federally funded, and if it is less than $\mathbf{2 5}$ acres in size the WOAHP will consider inspecting the project at no cost to the applicant. The decision depends on available personnel and funding.

The WOAHP maintains a log of the projects reviewed and the comments made.

Normally 30 days is allowed for the WOAHP to comment on federal projects. If the WOAHP has not commented in this period, the Agency can proceed with the Section 106 process. Allowances are made in cases where the normal review period would cause a delay in a project.

\section{Permit or Regulation: State Environmental Policy Act (SEPA) \\ Statutory Authority: Chapter 197-11 WAC Agency: Washington Department of Ecology (WDOE)}

The Washington State Environmental Policy Act (Chapter 43.21C RCW) requires state and local agencies to evaluate proposed projects for their environmental impact before issuing any permits or other approvals. Figure 12 highlights the key steps in the SEPA process and provides references to the applicable sections of the SEPA rules.

These rules are available in booklet format from any Washington Department of Ecology (WDOE) or Washington Department of Natural Resources (WDNR) office.

When a developer submits a permit application, the agency receiving the application determines whether or not the project is exempt from SEPA. If it is not, the agency then determines which agency requiring a permit is the "lead agency." The SEPA lead agency is responsible for complying with SEPA for a particular project. For any proposal involving a energy electrical generation project that is $250 \mathrm{MW}$ or greater, the lead agency is the Washington Energy Facility Site 


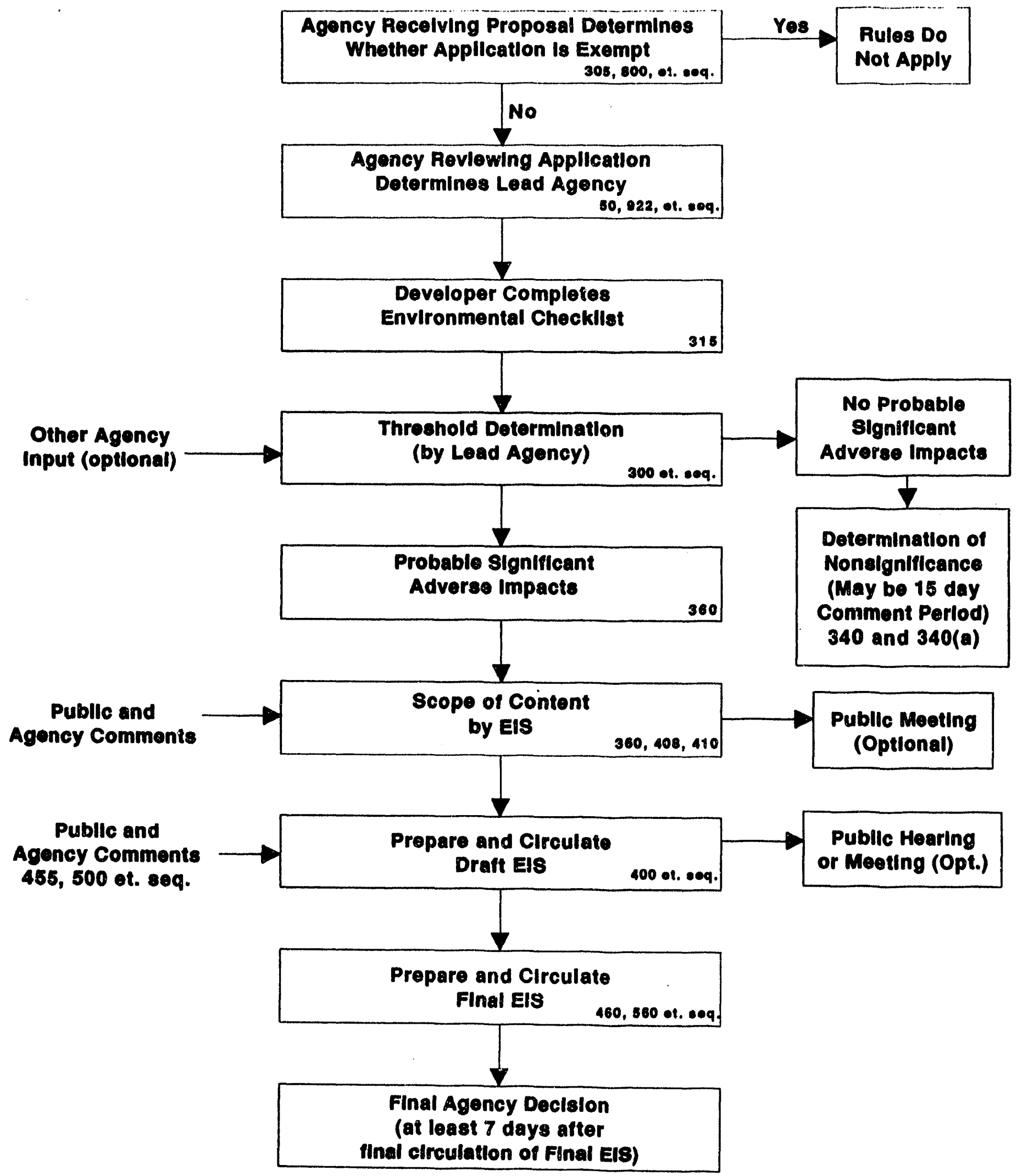

Figure 12: The Washington SEPA Process 
Evaluation Council (WEFSEC) (RCW section 80.50.020). For electrical generation projects under $250 \mathrm{MW}$, the lead agency is the WDNR or the city or county in which the project is located. A public agency proposing a energy project is most likely to be the SEPA lead agency for that project.

When SEPA compliance is required for a project, the developer must complete an environmental checklist, unless the developer and the lead agency agree that an environmental impact statement (EIS) will be prepared. The lead agency gives the checklist to the developer, who may complete it alone or together with the lead agency. The completed checklist provides specific information about the project, helps the developer and the lead agency identify potential impacts from the project (to reduce or avoid these impacts, if possible), and helps the agency decide whether an EIS is required.

When the lead agency receives the completed environmental checklist, it makes the Threshold Determination to decide whether an EIS is needed. If the lead agency determines the project is unlikely to have a significant adverse impact on the environment, it issues a Determination of Non-significance (DNS) and sends it to all agencies with permits or approvals to issue. These include agencies whose services would be affected by the project, affected Indian tribes, and interested persons. The lead agency must also give public notice that the DNS has been issued; the method will vary among agencies. Any person or agency may submit written comments on the DNS to the lead agency within 15 days from the date of issuance. If comments are received, the lead agency must reconsider the DNS. The lead agency is not required to modify the DNS, but may, however, determine that there is a significant impact and require preparation of an EIS.

Whenever the lead agency determines that there may be a probable significant adverse environmental impact, it must prepare an EIS. The EIS provides information about a proposed project and possible alternatives to the project to agency officials, project sponsors, and interested citizens. The lead agency must use a scoping process to narrow the contents of the EIS. During scoping, the lead agency consults with other agencies and the public. The lead agency then writes a draft EIS which focuses on the significant adverse impacts that may result from the project and its alternatives and discusses measures to mitigate or eliminate adverse impacts. The lead agency sends copies of the draft EIS to all agencies requiring a permit or other approval, to Indian tribes that may be affected by the project, and to interested citizens. Agencies and citizens have 30 days in which to comment on the draft EIS. The lead agency must give public notice for both scoping and the draft EIS.

After considering all comments on the draft EIS, the lead agency prepares a final EIS. This document includes all comments, the lead agency's response to the comments, and either the draft EIS is revised to respond to concerns expressed in the comments or corrections are made to the draft EIS. The final EIS is sent to all agencies that must make decisions on permits or other approvals.

Preparing and distributing the draft and final EIS and public hearings generally takes 3 to 6 months, but this can vary substantially. In certain cases, a joint SEPA EIS/NEPA EIS may be 
prepared. However, this requires close coordination with federal and state agencies. In other selected circumstances, a federal environmental assessment may be adopted by the SEPA lead agency as that agency's EIS (WAC 197-11-610).

The Environmental Permit Information Center (EPIC) of WDOE provides a centralized statewide environmental permit information service. The EPIC can answer general questions and provide certain services during the process of obtaining state environmental permits for activities on state and private lands. For WDOE address, see Appendix 1E.

The EPIC's Permit Information Line, (206) 459-6022, provides information on state environmental permits, public notice requirements, processing times, and appeal procedures as well as required federal and local permits. The EPIC can identify the agencies involved and their locations. The EPIC can assemble a Permit Application Packet, tailored to the specific needs of a project, and send it to an applicant.

Permits may be applied for individually, or a special process may be used to obtain several environmental permits as a package. The Environmental Coordination Procedures Act (BCPA) was adopted by the Washington State Legislature in 1973 to coordinate permit procedures. This process gives an applicant the option of submitting a Master Application form to assist in identifying necessary permits for the proposed development. If this service is used, the Center acts as the permit coordinator and assists the applicant from application through final disposition.

Not every energy project requires every state permit listed in Table 24 . Generally, large developments require most of these; a small facility may only need three or four of the possible permits.

\section{Approximate Time Required to Obtain Determination}

Approximate time estimates given for project development are just that-estimates. Time requirements will vary, depending on the complexity of the project and the amount of controversy involved. If several public hearings or court actions are involved before a permit can be issued, the length of time necessary for approval will increase substantially. Approximate time required is 3 weeks to 3 years.

\section{Permit or Regulation: Temporarily Remove or Destroy Survey Monument Statutory Authority: 332-120 WAC} Agency: Washington Department of Natural Resources (WDNR)

This permit is issued by the Washington Department of Natural Resources (WDNR) subject to the provisions of Chapter 332-120 WAC, which requires adequate referencing and replacement of the monument or reference monuments after the development has been completed. A description of existing conditions and reason for removal are required. Coordination with the Washington Coordinate System may be required. 
Approximate Time Required to Obtain Permit

It will take about 1 week to receive this permit.

\section{Safety/Health}

This section deals with regulations designed to protect public health and safety. Included are a number of permits dealing with hazardous, dangerous, and solid waste. The Washington Department of Ecology (WDOE) has several programs devoted to managing waste to protect public health and the environment.

\section{Permit or Regulation: Burning}

Statutory Authority: $R C W$ 76.04.150

Agency: Washington Department of Natural Resources (WDNR)

This permit should be applied for after construction, when the contractor has piled all debris for burning and fulfilled all safety precautions. An inspector will be sent to examine the site; if it is safe, a permit will be issued at the site.

Approximate Time Required to Obtain Permit

It will take about 1 week to receive this permit.

\section{Permit or Regulation: Certificate of Designation}

Statutory Authority: $R C W$ 70.105; $173-303$ WAC

Agency: Washington Department of Ecology (WDOE)

A certificate of designation is issued for voluntary review of potentially hazardous waste. The function of the certificate is to determine designation of waste (Dangerous, Extremely Hazardous, or Undesignated).

\section{Permit or Regulation: Hazardous/Dangerous/Solid Waste}

Statutory Authority: RCW 70.105; 173-303 WAC

Agency: Washington Department of Ecology (WDOE)

The Washington Department of Ecology (WDOE) is responsible for identifying, investigating, and cleaning up hazardous waste sites. Any contaminated site must be reported, by the facilities' owner or operator, to WDOE. Facilities found contaminated and that require remedial action are placed on a hazardous waste site list maintained by WDOE. Contaminated sites must be cleaned up in accordance with state standards. Cleanups may be done independently (without WDOE oversight or approval); however, all cleanups must be reported to WDOE and are subject to later review. For this reason, owners and operators are encouraged to contact WDOE to develop an approvable testing and cleanup plan. 
Permit or Regulation: Hazardous Waste Release Notification

Statutory Authority: $R C W$ 70.105; $173-303$ WAC

Agency: Washington Department of Ecology (WDOE)

Prompt notification to the Washington Department of Ecology (WDOE) is required when spills or releases of hazardous substances occur that have the potential to impact human health or the environment. Responsibility for reporting spills lies with the person who spills or releases the substance; however, any person aware of such spills is encouraged to contact WDOE.

Permit or Regulation: Identification Number/Reporting Requirements (Hazardous Waste) Statutory Authority: RCW 70.105; 173-303 WAC Agency: Washington Department of Ecology (WDOE)

An EPA/State identification number is required for persons who generate, transport, or offer for transport hazardous wastes going to a storage, treatment, and/or a disposal facility.

An annual reporting of hazardous waste management activities is required of the owner or operator of a facility that has an active EPA/State identification number.

Permit or Regulation: On-Site Sewage Disposal Statutory Authority: RCW 90.48; 173-240 WAC Agency: Washington Department of Ecology (WDOE); Washington Department of Health Services (WDOH); or Local Health Department

Businesses and residences that locate outside areas served by sewer systems frequently treat and dispose of sewage on the property where it originates through septic tanks and subsurface disposal fields. These systems are reviewed and approved by local health departments, the Washington Department of Health (WDOH), or the Washington Department of Ecology (WDOE) depending on the size and nature of the system.

Local health departments issue permits for on-site sewage with design flows, at any common point, less than 3,500 gallons/day.

\section{Permit or Regulation: Special Motor Vehicle}

Statutory Authority: RCW 46.44.090

Agency: Washington Department of Transportation (WDOT)

This permit may be issued by the Washington Department of Transportation (WDOT) at the time of application for activities using oversized or overweight vehicles. Information on tire size, number of tires, the weight and size of the vehicle, and the current registration must be supplied. The permit may be applied for by the contractor or by the developer. 
Approximate Time Required to Obtain Permit

This permit can be obtained in 1 day.

Permit or Regulation: Underground Storage Tank Notification Requirement

Statutory Authority: 40 CFR 280.22; RCW 90.76

Agency: Washington Department of Ecology (WDOE)

If a developer has installed or intends to install an underground storage tank (UST), a state UST notification form must be completed. This form is available from the Washington Department of Ecology (WDOE). WDOE administers a federal requirement to report regulated underground storage tanks and information about these tanks.

Currently, under federal requirements, notification is required within 30 days of putting into service a new tank.

\section{Water Quality/Water Use}

Washington State has what appears to be an abundant water supply. However, because of geographic and seasonal shortages, water supplies are not always adequate or available. In addition, the total water supply is finite; there will never be more. Because Washington's population is increasing there is an expanded water demand for all purposes domestic, industrial, agricultural, recreational, as well as power generation. The permits listed below are part of Washington's water resource management strategy.

It is Washington State's policy to "...maintain the highest possible standards to ensure the purity of all waters of the state consistent with public health and public enjoyment...the propagation and protection of wildlife, birds, game, fish and other aquatic life, and the industrial development of the state."

There are many activities during energy exploration and development that have the potential to impact water quality. Pollution from these and other activities can be reduced if appropriate methods are used. During the permitting process, agency experts can design the project to control and prevent pollution of streams, rivers, lakes, and other surface and ground waters of the state.

Water diversion devices will be equipped with a well-maintained fish guard (RCW 75.20.050).

Where practical, dams and other obstructions across or in a stream will be equipped with a durable and efficient fish way (RCW 75.20.060). 


\section{Permit or Regulation: Flood Control Zone}

Statutory Authority: RCW 86.16.080

Agency: Washington Department of Ecology (WDOE)

This permit is required for the construction of any new structure, or the reconstruction or modification of an existing structure within designated flood control zones. Permit applications should include plans showing dimensions and elevations of planned obstructions and provisions for water passage through, around, and over works. Known high water marks and dates should also be included.

The counties of King, Cowlitz, Skagit, Kittitas, Clallam, Thurston, and Clark administer the flood control zone permit systems within their county boundaries. Applications for permits in these counties should be made through the local building or planning department, or through contacting the nearest Washington Department of Ecology (WDOE) Regional Office listed in Appendix 1E. This permit may require SEPA compliance.

Approximate Time Required to Obtain Permit

This permit process should take about 1 month.

\section{Permit or Regulation: Groundwater Management Areas}

Statutory Authority: RCW 90.44; 173-100 WAC

Agency: Washington Department of Ecology (WDOE)

In response to the growing concern about the state's groundwater resource, the Washington Department of Ecology (WDOE) is legislatively mandated to coordinate the development of groundwater management programs. Local governments are responsible for developing WDOEapproved groundwater management plans. Activities within groundwater management areas are required to comply with ordinances/regulations established as part of a groundwater management plan.

Permit or Regulation: National Pollutant Discharge Elimination System (NPDES)

Statutory Authority: RCW 90.43, 90.50, 90.52; 173-220 WAC Agency: Washington Department of Ecology (WDOE)

A National Pollutant Discharge Elimination System (NPDES) permit is required where a waste water source is discharged to "waters of the United States." In lieu of holding such a permit, a state discharge permit is required under provisions of RCW 90.48.160-162.

The application requires information on waste source flow and expected characteristics, disposal method, water supply, waste water disposal, water supply volumes, water utilization, planned improvements, storm water treatment, plant operation, materials and chemicals used, and production. Prior SEPA compliance is required. 
Approximate Time Required to Obtain Permit

The application process takes about 2 to 6 months to complete.

\section{Permit or Regulation: Public Water Supply Approval \\ Statutory Authority: 248-54 WAC \\ Agency: Washington Department of Health (WDOH)}

This approval is given in two parts. First is a preliminary design review that takes 60 days; second, a final plans and specifications review that takes 30 days. See 248-54 WAC, sections 085 and 095 for details. After construction is completed, there will be a final review of the approved plans and the as-built drawings to see if there are any significant changes. Ultimate approval is subject to SEPA compliance. The preliminary design should be turned in as soon as possible, and the final plans shortly before SEPA compliance to allow for review time.

Approximate Time Required to Obtain Approval It will take about 3 months.

\section{Permit or Regulation: Sewage Holding Tank Variance}

Statutory Authority: 248-96 WAC; revised (6/92) 246-272 WAC Agency: Washington Department of Health (WDOH); Local Health Department

An application for this permit can be obtained from the local Health Department. The following should be included with the application: a drawing of the proposed facility including location and size; information on maintenance schedules; precautions to be taken against overflow; and a signed contract with a holding tank pumping firm that indicates a servicing schedule and a backup pumping firm.

\section{Permit or Regulation: State Waste Discharge Permit \\ Statutory Authority: RCW 90.48, 90.52, 90.54; 173-216, 173-224 WAC \\ Agency: Washington Department of Ecology (WDOE)}

Through these permits, the Washington Department of Ecology (WDOE) regulates the discharges or disposal of industrial, commercial, or municipal waste material into the state's groundwaters, and the discharge of industrial or commercial wastes into municipal sewer systems.

The permit application requires information on water supply volume, water utilization, wastewater flow, characteristics and disposal methods, planned improvements, storm water treatment, plant operation, materials and chemicals used, production, and other relevant information. WDOE generally requires public ownership, operation, and maintenance of domestic wastewater facilities. 
Permit or Regulation: Wastewater Facilities Plan Approval

Statutory Authority: $R C W$ 90.48.110 and 173-240 WAC

Agency: Washington Department of Ecology (WDOE)

Engineering reports, plans, and specifications for construction of new sewage or industrial waste treatment or disposal systems, including systems for erosion/sedimentation control, disposal of wastewater from concrete batching and coring, etc., must be subinitted for review and approval by the Washington Department of Ecology (WDOE). Prior SEPA compliance is required.

\section{Permit or Regulation: Water Quality Certification and Modification} Statutory Authority: Section 401, Federal Water Pollution Control Act; 173-225 WAC/RCW 90.48.120; 173-201-035(8e) WAC Agency: Washington Department of Ecology (WDOE)*

A Water Quality Certification is a statement issued by the Washington Department of Ecology (WDOE) that the proposed activity will comply with applicable water quality standards and discharge limitations. Issuance of a certification is exempt from SEPA requirements.

Because most new energy construction activities will unavoidably violate state water quality criteria (particularly the turbidity criterion) on a short-term basis, such projects will require a Shortterm Modification of Water Quality Criteria. A modification may be required before WDOE can issue a Water Quality Certification. SEPA compliance is required for a modification.

To request a certification and/or modification, a letter containing the following information should be sent to WDOE: project description, including location and proposed activities; and the nature of any water quality violation expected, including specific criteria which will be violated, the scheduled duration and extent of these occurrences, and methods proposed to minimize the impact on water quality. Depending on the project, a review of plans and specifications may also be required.

Approximate Time Required to Obtain Certification

This process takes about 2 months to 1 year.

- Applications and letters of request should be sent to the appropriate regional office of WDOE. 


\section{Permit or Regulation: Water Right}

Statutory Authority: RCW 18.104, 43.27A, 90.03, 90.14, 90.16, 90.22, 90.44, and

$90.54 ; 173-100,173-136,173-50,173-154,173-166,173-500$, and 173-590 WAC

Agency: Washington Department of Ecology (WDOE)*

Informati in required for this permit application includes the following:

- a section map

- the source of the water supply

- how the water will be used

- the exact location of the point of diversion or withdrawal

- a legal description of the property on which the water is to be used

- the signature of the legal landowner

- a description of the proposed water system.

This application should be submitted as early as possible to establish a priority date, the nature and amount of proposed use, date construction will be completed, and the date of complete appliation of water to beneficial use. Processing begins when an application is received by the Washington Department of Ecology (WDOE). SEPA compliance is required before issuance of this permit.

Individuals or corporations may exercise the right of eminent domain to acquire water rights or property necessary for water conveyance (see RCW 90.03 or 90.16).

Approximate Time Required to Obtain Permit

It will take anywhere from 18 to 24 months.

\section{Local Permitting and Licensing Requirements}

Local governments such as cities, counties, road districts, flood control districts, and drainage distrirts will have some jurisdiction over energy development in nearly all cases. Most county governments require building permits for construction and entail building code, electrical code, and plumbing code compliance. Most counties also have planning and zoning commissions that will review project plans for compliance with comprehensive plans, zoning regulations, and needs for conditional or special use permits. Counties may also have some jurisdiction over construction in or near defined flood plains and over use of, or construction near, county highways. The county courthouse, the county zoning administrator, and the county highway district are the best contacts for determining what permits or approvals will be required.

- State pernits may be applied for prior to SEPA compliance; however, most permits require SEPA compliance before issuance. 
If a proposed site is within a city's limits or within its area-of-impact, appropriate contact should be made with city officials regarding building permits, zoning regulations, flood plain construction, and highway usage. Contact the city hall of the nearest city for a determination of the required permits and approvals and jurisdiction.

\section{Permit or Regulation: Water Well Construction and Operator's License Statutory Authority: RCW 18.104 Agency: Washington Department of Ecology (WDOE)}

This license authorizes a person to engage in the construction of water wells for compensation. To qualify for a construction operator license the applicant must have at least 2 years of experience with a licensed well driller (or qualifying experience), and pass a written examination administered by the Washington Department of Ecology (WDOE).

All wells constructed in the state must meet the minimum standards for construction and maintenance of wells as outlined in 173-160 WAC. Documentation of well construction must be provided to WDOE in the form of a start card filed before the well is constructed.

\section{Local Permits}

The local county or city government is responsible for the orderly growth ad development of the community. The following will provide general information and directions to the appropriate local offices for obtaining local zoning and building codes comprehensive land use and shoreline plans, and local development policies

As a participating Environmental Coordination Procedures Act (ECPA) agency, a local government may coordinate local permits and approvals with state permits when the ECPA master application process is used.

Smaller communities often issue all permits through a single office, such as the Clerk. In some counties, one or more highway districts exist that are responsible for construction and maintenance of roads. These agencies will be the administrators of all permits/approvals having to do with public rights-of-way.

A number of these permits, mainly those administered by the Planning Department, will irivolve substantial discretionary action on the part of the decision makers, approval being based on conformance of plans with established criteria or standards. Therefore, these decisions wili usually be made by elected or appointed officials (city councilmen, county commissioners, or planning and zoning commissioners). Another group of approvals will be based on the adequacy of technical plans. These will generally be the permits listed as being administered by the public works department and building department. Several items will be simpiy a matter of registration, including the business license and registration of proprietorship. The following is a general description of each of the permits and approvals which may be required. 
Within the framework of federal and state regulation, local governments perform duties which can have unique and significant impacts on energy project development. Local govermments can set an example by financing and developing energy facilities themselves. They can encourage private development through information distribution and active recruiting of facilities. Cities and counties also regulate energy facilities. Below state-level citing thresholds, the jurisdictions are the primary development permitting authority. They set land use policy which controls the type and location of future development and affect construction techniques by enforcing building and electrical codes. They direct the division of lots through subdivision ordinances. They also regulate the type, mix, and location of land uses using zoning ordinances.

Zoning ordinances implement policies established in local land use plans and reduce land use conflicts by dictating: 1) the type of development allowed within the jurisdiction; 2) the design of those uses; and 3) the way potentially conflicting uses may coexist.

Policies and standards reflect both technical information and popular opinion. Local land use law often reflects values that are difficult to evaluate objectively. Public participation in a project approval may reveal concerns for property values, neighborhood quality and scenic quality. These subjective values are difficult to put into laws. Few local governments have done more with energy facility regulation than provide a forum for public involvement in siting decisions.

In some states, counties and incorporated cities prepare and adopt comprehensive land use plans which are acknowledged by a state-level commission. The plans indicate the location and significance of affected resources and provide a regulatory framework for potentially using them. If a conflict is identified which is resolved against energy resource development, then another site must be found, unless the plan is amended. If the conflict is resolved in favor of energy resource development then, from a land use perspective, resource use is feasible. Development still may be subject to conditions which mitigate negative impacts. These requirements are described in the plan and local ordinances. Thus, developers can use comprehensive plans to leam what kind of projects might be feasible, and under what conditions.

In the absence of attention to the energy resource in the local land use plan, a prospective developer may have to champion a project proposal through the entire land use planning, zoning, and ordinance-writing processes. Such an effort would add many months to a project's lead time and increase its cost. Along the way, design changes are likely or the project may be found infeasible. The local government and public would be involved in broad planning, policy making, and ordinance issues in the context of cummunity reaction to a proposed project. 


\section{Air Pollution}

Permit or Regulation: New Air Contaminant Source Registration

Statutory Authority: 70.94.151 - $152 \mathrm{RCW}$

Agency: Air Pollution Control Authority (APCA)

Each county of the state is designated with a air pollution control authority which bears the name of the county it is located. Every activated authority operating an air pollution control program shall have requirements for the control of emissions which are no less stringent than those adopted by the Washington Department of Ecology (WDOE) for the geographic area in which the air pollution control program is located.

\section{Construction}

\section{Permit or Regulation: Commercial Building Permit Agency: Local Planning Department; Building Permit Agency}

Permits to construct permanent buildings or additions to existing facilities are required by counties and cities. The application requires detailed final design plans for structures including electrical plan, plumbing plan, floor layout, sewage facilities, drainage plan, size and shape of lot and buildings, size and shape of foundation walls, beams, air vents, window accesses, and heating or cooling plants, if included in the design. Four sets of detailed plans and specifications must be included in the application.

The Building Permit is dependent on the approval of the Drainage Plan, Shoreline Development Permit, Zoning Variance, and SEPA compliance (the last two may or may not be required).

\section{Permit or Regulation: Grading Permit Agency: Local Planning Department}

Plans and specifications containing the following information should be submitted: the nature, extent, location, and compliance with the Uniform Building Code; existing contours, terrain, and area of drainage; limiting dimensions, contours, and proposed drainage channels after construction; plans and maps for all drainage devices, walls, cribbing, or dams; estimated area runoff; and the location of any existing or proposed building in the grading area. A Soil Engineering Report, the status of SEPA compliance and other local permits, and the Surface Water Drainage Plan should also be included.

This permit cannot be issued until SEPA compliance is established. 
Permit or Regulation: Inter-local Agreement for Construction on County Roads Agency: Local Department of Public Works

The applicant initiates the short-term agreement by sending a letter to the director of the Department of Public Works describing the intended use and proposed upgrading and maintenance work. The letter should contain a draft contract for the agreement between the county and the applicant. The letter should include descriptions of proposed road construction, drawings illustrating materials to be used, and road bed and drainage design. A copy of the state environmental checklist or SEPA document should also be included.

\section{Permit or Regulation: Operate Overweight Vehicles on City or County Roads} Agency: Local Department of Public Works

This permit may be obtained by the contractor. The following information is required for each application:

- the size and number of tires

- weight of vehicle

- the current registration of the vehicle.

Permit or Regulation: Plumbing, Electrical, Mechanical Agency: Local Building Permit Agency

Plumbing, electrical, and mechanical plans prepared by a licensed plumber, electrician, engineer, or architect should be submitted along with an application card. The plans should show all fixtures that will be installed, the types and sizes of pipe, cable, etc., that will be used. A list of fixtures should also be included.

\section{Permit or Regulation: Surface Water Drainage Plan Approval} Agency: Local Department of Public Works

A Drainage Plan Approval is needed prior to issuance of the following permits: Building, Grading, and Shoreline Development. A preliminary drainage review of the natural and planned drainage improvements is prepared and used to determine if a detailed drainage review is necessary. The preliminary approval is sufficient for the shoreline development permit hearings.

\section{Permit or Regulation: Temporary Road Closure} Agency: Local Department of Public Works

This permit can be granted over the counter to the contractor 5 days before it is needed. The application calls for a description of the proposed activity, the construction schedule, and the exact location of the proposed road closure. 
Permit or Regulation: Utility

Agency: Local Department of Public Works

A letter requesting this permit should be sent to the local Department of Public Works. It should include a set of plans relating to the transmission line leading from the power house to the intertie, a description of the proposed construction of the transmission line, and a construction schedule.

\section{Environment and Health}

\section{Permit or Regulation: Sewage Holding Tank Variance}

Statutory Authority:

Agency: County Health Department

An application for this permit can be obtained from the local Health Department. The following should be included with the application:

- a drawing of the proposed facility including location and size

- information on maintenance schedules

- precautions to be taken against overflow

- a signed contract with a holding tank pumping firm which indicates a servicing schedule and a backup pumping firm.

\section{Permit or Regulation: State Solid Waste Management Act}

Statutory Authority: Chapter 173-304 WAC, Chapter 70.95 RCW

Agency: Washington Department of Ecology (WDOE); County Health Departments

The county Health Departments regulate the storage, transport, and disposal of solid waste. The counties have adopted rules consistent with Chapter 173-304 WAC as authorized under the State Solid Waste Management Act, RCW 70.95.

Application of a Solid Waste Permit must be made to the appropriate county health department. the Washington Department of Ecology (WDOE) provides review of the application upon request by the county.

\section{Land Use}

Permit or Regulation: Shoreline Management Substantial Development Permit (Shoreline Permit)

Statutory Authority: RCW 90.58.104; 173-14 through 173-28 WAC

Agency: Washington Department of Ecology (WDOE); Local Planning Department

To determine whether this permit is needed, the Shoreline Master Program at the pertinent county or city office should be consulted. The plan will specify whether energy is an allowed use for the proposed area. The procedure for obtaining this permit varies from county to county. 
Generally, a public hearing is required. The Hearing Examiner will require an affidavit of public notice, a location map, a topographic map, and a site map. If a variance or conditional use permit is required, WDOE must give the final approval. SEPA compliance must be shown hefore final approval will be given.

\section{Permit or Regulation: Flood Plain Development \\ Statutory A uthority: RCW 86.16; 173-158 WAC \\ Agency: Local Planning Department}

Local govemments participating in the National Flood Insurance Program (NFIP) are required to review proposed construction projects to determine if they are in identified flood plains as shown on the NFIP maps. If a project is located in a mapped flood plain, the local government must require a development permit to be obtained prior to construction.

Proposed projects are reviewed and conditions imposed on any permits issued to reduce the potential for damage from flood waters. Permits are required for structures as well as for filling or grading activities in the flood plain.

State law requires that local entities have a local flood plain ordinance that meets or exceeds NFIP requirements. The Washington Department of Ecology (WDOE) has approval authority over these ordinances.

For permit applications or additional information, contact the local city or county Building or Planning Department.

\section{Permit or Regulation: Zoning Conditional Use/Zoning Code Variance Agency: County Boards of Commissioners; County Department of Public Works}

In counties where a master plan is being implemented and where a project would conflict with planned land uses, a Conditional Use Permit or variance is required. The application is reviewed by a Hearing Examiner and requires a public hearing conducted by the Board of Commissioners. A preliminary drainage plan must be approved by the county Public Works Department prior to a public hearing for the substantial development and zoning permits.

\section{Water Quality/Water Use}

\section{Permit or Regulation: On-Site Sewage Disposal Permit Agency: Washington Department of Ecology (WDOE); County Heailh Department}

Businesses and residences that locate outside areas served by sewer systems frequently treat and dispose of sewage on the property where it originates through septic tanks and subsurface disposal field. These systems require approval of local Health Departments, the Washington De- 
partment of Health, or the Washington Department of Ecology, depending on the size and nature of the system. Local Health Departments issue permits for on-site sewage with design flows, at any common point, less than 3,500 gallons/day.

\section{Permit or Regulation: Surface Water Drainage Plan Approval Agency: Local Public Works Departments}

The exact form required for this approval can be found in the local public works department Procedures Manual. A Preliminary Drainage Review of the natural and planned drainage improvements is prepared and used to determine if a Detailed Drainage Review is necessary.

A Drainage Plan Approval is needed prior to issuance of the following permits: Building, Grading, and Shoreline Development. The Preliminary Approval is sufficient for the Shoreline Development Permit hearings. There is no fee for the Preliminary Approval. The fee for the Detailed Review is based on the fee schedule for the associated local permits and approvals requiring the Drainage Plan. Prior to any site work, an inspection fee is required.

\section{Other Permits}

\section{Permit or Regulation: Noise Ordinances \\ Statutory Authority: Chapter 173-60 WAC Agency: Local Planning Department}

Noise abatement and control is primarily the role of local government, and many local entities have adopted noise ordinances. Chapter 173-60 WAC, Maximum Environmental Noise Levels, establishes noise levels that cannot legally be exceeded. Permissible noise levels established by this regulation vary depending on the source of noise (residential, commercial, industrial), and source receiving the noise. For more information about noise ordinances that apply in your area, contact your local planning department. 


\section{Glossary}

\section{A-95 REVIEW}

ACDP

ADVISORY COUNCIL ON HISTORIC PRESERVATION

AIR QUALITY

MAINTENANCE AREA

ALTERNATING CURRENT (AC)

AMBIENT AIR QUALITY

AMICUS CURIAE

APCA

AMW

AQMA

ARCHAEOLOGICAL RESOURCE

\section{ARCHAEOLOGY}

State coordinated review of federally funded projects.

Air Contaminant Discharge Permit

The 19 member Council is composed of a Chairman, Vice Chairman, six other private citizen members, a governor, and a mayor, all appointed by the President of the United States. The Council also includes the secretaries of the Interior and Agriculture, the heads of four federal agencies designated by the President (currently Treasury, HUD, Transportation, and the Office of Administration), the Architect of the Capitol, the Chairman of the National Trust for Historic Preservation, and the President of the National Conference of State Historic Preservation Officers. The Council members usually meet four times during the year. Day-to-day business of the Council involving Section 106 review is conducted by an Executive Director and a professional staff of historians, architects, archaeologists, planners, lawyers, and administrative personnel. The Advisory Council on Historic Preservation formulates the procedures for the protection of historic sites that all federal agencies have to follow, and through Section 106 of the Historic Preservation Act of 1966 the Advisory Council ensures compliance.

Specific populated area where air quality is a problem for one or more pollutants. (Portland-Vancouver, Salem, Eugene-Springfield, Medford-Ashland). AQMAs encompass non-attainment areas.

Electricity that reverses its direction of flow periodically, as contrasted to direct current (DC).

The condition of the air in the surrounding environment

A person who is called in or offers to advise a court on some legal matter.

Air Pollution Control Authority

Average Megawatt

Air Quality Maintenance Areas

A term with legal definition and application that means any material remains of human life or activities that are at least 100 years of age, and that are of archaeological interest.

The subfield of anthropology engaged in the theory and practice of recovering, analyzing, interpreting, and explaining evidence of the human prehistoric and historic past; the 
A.R.M.

ARTIFACT

ASME

ATTAINMENT AREA

AVAILABILITY FACTOR

AVOIDED COST

BACKUP ELECTRICITY

BACKUP RATE

BACT

BAGHOUSE

BASELOAD

BASELOAD CAPACITY

BASELOAD DEMAND

BASELOAD STATION time-depth arm of anthropology. Archaeology as a scholarly encleavor is not limited in the scope of its subject matter by legal or regulatory provisions such as the minimum age assigned to archaeological resources (for enforcement purposes) by the Archaeological Resources Protection Act.

Administrative Rules of Montana

Literally, human made, not natural; any object that shows evidence of human manufacture, modification, or use. In common usage, normally refers to portable prehistoric items such as implements made of stone, bone, pottery, or other durable material.

American Society of Mechanical Engineers

A geographic area where the concentration of specific air pollutant does not exceed federal standards.

The percentage of time a plant is available for power production.

The payment made for the capacity and energy of a small power project; such payment equals the cost to a utility of obtaining and operating additional generating units, or to purchase power from another source, if this power were not available. Also called avoidable cost.

Power and/or services that are only occasionally needed, e.g., when on-site generation equipment fails.

A utility rate applied to backup electricity.

Best available control technology

A device that removes particles from furnace stack gases. Dirty gas is passed through filter bags.

The amount of electric power needed to be delivered at all times and all seasons.

A reference to electricity production; the power output that can be continuously produced. Usually computed by considering equipment that the operator/utility intends to run at least 70 percent of the time.

The minimum demand experienced by an electric utility, usually 30-40 percent of the utility's peak demand. At any time the utility's customers may need power equal to or greater than the base load demand.

A power generating station usually operated at a constant output to take all or part of the base load of a system. 
BATF

BCA

BCC

BEST AVAILABLE CONTROL TECHNOLOGY (BACT)

BHES

BIA

BIOCHEMICAL CONVERSION PROCESS

\section{BIOENERGY}

BIOGAS

BIOLOGICAL ASSESSMENT

BIOLOGICAL OPINION

\section{BIOLOGICAL OXYGEN DEMAND}

Bureau of Alcohol, Tobacco, and Firearms

Building Codes Agency

Board of County Commissioners

An errission limitation based on the maximum degree of reduction of each pollutant subject to regulation and emitted from or which results from any major emitting facility. The permitting authority, taking into account energy, environmental and economic impacts, and other costs, on a case-by-case basis determines what is achievable for each facility through application of production processes and available methods, systems, and techniques. This includes fuel cleaning or treatment or innovative fuel combustion techniques for control of each pollutant.

Board of Health and Environmental Sciences (Montana)

Bureau of Indian Affairs

The use of living organisms or their products to convert organic material into fuels.

The conversion of the complex carbohydrates in organic matter into energy, either by using it directly as a fuel or by processing it into liquids and gases that are more efficient.

A combustible gas derived from decomposing biological waste. Biogas normally consists of 50 percent to 60 percent methane.

The information concerning listed and proposed species and Critical Habitat and proposed Critical Habitat that may be present in the action area that the federal or designated non-federal representative must gather and evaluate on any major construction activity.

The document that states the opinion of the PWS as to whether or not a federal action is likely to jeopardize the continued existence of listed species or result in the destruction or adverse modification of Critical Habitat.

A standard means of estimating the degree of contamination of water supplies, especially those which receive contamination from sewage and industrial waste. It is expressed as the quantity of soluble oxygen required during stabilization of the decomposable organic material. The dissolved oxygen is required to decompose organic matter in water. It is a measure of pollution because heavy waste loads have a high demand for oxygen. 
BIOMASS

BIOMASS ENERGY

BIOMASS FUEL

BLC

BLM

BNRC

BOGC

BOILER

BPA

BRITISH THERMAL UNIT (Btu)

Btu

CANDIDATE SPECIES

CAPACITY

CAPACITY FACTOR

CAPACITY VALUE
Any organic matter which is available on a renewable basis including forest residues, agricultural crops and wastes, wood and wood wastes, animal wastes, livestock operation residue, aquatic plants, and municipal wastes.

Biomass fuel, energy, or steam derived from the direct combustion of biomass for the generation of electricity, mechanical power, or industrial process heat.

Any liquid, solid, or gaseous fuel produced by conversion from biomass.

Board of Land Commissioners (Montana)

U.S. Bureau of Land Management

Board of Natural Resources and Conservation (Montana)

Board of Oil and Gas Conservation (Montana)

A closed vessel in which water is heated, steam is generated, steam is superheated, or any combination thereof, under pressure or vacuum by the direct application of heat from the combustion of fuels, or from electricity or nuclear energy. The term shall include fired units for heating or vaporizing liquids other than water where these units are separate from processing systems and are complete within themselves, and related appurtenances.

\section{Bonneville Power Administration}

Quantity of heat required to raise the temperature of one pound of water 1 degree Fahrenheit.

\section{British thermal unit}

Any species being considered by the Secretary of Interior for listing as an endangered species or a threatened species. Separate lists for plants, animals, and invertebrates are published periodically in the Federal Register.

The maximum power output or the load for which a generating unit, generating station, or other electrical apparatus is rated. Common units include kilovolt-ampere $(\mathrm{kVa})$, kilowatt (kW), and Megawatt (MW).

The ratio of the energy that a plant produces to the energy that would be produced if it were operated at full capacity throughout a given period, usually a year. Sometimes calle the plant factor.

The part of the market value of electric power that is assigned to dependable capacity. 


\section{CAPITAL COST}

CFR

CG

CIRCUIT BREAKER

CLASS I AREA

CLASS II AREA

$\mathrm{CO}$

$\mathrm{COE}$

COGENERATION

COMBUSTION

CONDITIONAL USE

PERMIT (CUP)

COOPERATING AGENCY

$\mathrm{COU}$

COUNCIL

CRITICAL HABITAT
The total investment needed to complete a project and bring it to an operable status that is commercial.

Code of Federal Reguicitions, published by the Office of the Federal Registrar, National Archives and Records Service of the General Services Administration.

Cogeneration

A switch that automatically opens to cut off an electric current when an abnormal condition occurs.

Any area which is designated for the most stringent degree of protection from future degradation of air quality.

Any area cleaner than federal air quality standards which is designated for a moderate degree of protection from future air quality degradation. Moderate increases in new pollution may be permitted in a Class $I$ area.

Carbon monoxide

\section{U.S. Army Corps of Engineers}

The technology of producing electric energy and forms of useful thermal or mechanical energy for industrial, commercial, heating, or cooling purposes, through the sequential use of an energy source.

The transformation of wood into heat, chemicals, and gases through chemical combination of hydrogen and carbon in the wood fuel with oxygen in the air.

Site outside appropriate zoning class approved for use with conditions.

Any federal agency, other than a lead agency, that has jurisdiction by law or special expertise with respect to any environmental impact involved in a proposal (or a reasonable alternative) for legislation or other major federal action significantly affecting the quality of the human environment. The selection and responsibilities of a cooperating agency are described in 1501.6. A state or local agency of similar qualifications or, when the effects are on a reservation, an Indian tribe may by agreement with the lead agency become a cooperating agency.

Consumer-owned utility

The Council on Environmental Quality established by Title II of the National Environmental Policy Act.

An area designated as such in the Bureau of Land Management (BLM) Manual and is any air, land, or water area (ex- 


\section{CULTURAL}

\section{CULTURAL RESOURCE}

CUMULATIVE IMPACT clusive of those existing manmade structures or settlements which are not necessary to the survival and recovery of a listed species) and constituent elements thereof, the loss of which would appreciably decrease the likelihood of the survival and recovery of a listed species or a distinct segment of its population. The constituent elements of Critical Habitat include, but are not limited to: physical structure and topography, biota, climate, human activity, and the quality and chemical content of land, water, and air. Critical Habitat may represent any portion of the present habitat of a listed species and may include additional areas for reasonable population expansion.

Of or pertaining to culture, which is the regularized, patterned, learned behavior shared by members of an interacting social group and passed from generation to generation, comprising the group's technology, economy, religion, arts, social organization, and more; a group's partly subconscious consensus on how things are done. Aspects of culture vary among contemporary groups and change through time. Culture may be viewed as a complex set of instrumental behaviors interposed between a group and its natural and social environment, and may be said to constitute the group's adaptation to its environment.

A broad, general term meaning any cultural property and any traditional life way value, as defined below.

1. Cultural Property: a definite location of past human activity, occupation, or use identifiable through field inventory or survey, historical documentalion, or oral evidence. The term includes archaeological, historic, or architectural sites, structures, or places with important public and scientific uses, and may include definite locations of traditional cultural or religious importance to specified social and/or cultural groups. Cultural properties are concrete, material places and things that are classified, ranked, and managed through the system of inventory, evaluation, planning, protection, and utilization.

2. Traditional Life Way Value: the quality of being useful in or important to the maintenance of a specified social and/or cultural gioup's traditional systems of religious belief, cultural practice, or social interaction, not closely identified with definite locations. Another group's shared values are abstract, nonmaterial, ascribed ideas that one cannot know about without being told. Traditional life way values are taken into account through public participation during planning and environmental analysis.

The impact on the environment which results from the action when added to other past, present, and reasonable 
CUP

dBA

DEIS

UEMANL

DENSIFICATION

DEQ

DESTRUCTION or ADVERSE MODIFICATION

DIGESTER

DIRECT BURIAL

DIRECT CURRENT (DC)

DNS

ECPA

EFFLUENT

EFSC

EFSEC

EIS foreseeable future actions regardless of what agency or person undertakes such other actions. Cumulative impacts can result from individually minor but collectively significant actions taking place over a period of time.

\section{Conditional Use Permit}

Decibels A scale, measures of sound levels. ABA LA-50 refers to a weighted sound level.

Draft Environmental Impact Statement

The rate at which electrical energy is delivered to a system, to part of a system, or to a piece of equipment; it is usually expressed in kilowatts, megawatts, etc.

A process that compresses biomass (usually wood waste) into pellets, briquets, cubes, or densified logs by subjecting it to high pressure.

Division of Environmental Quality (Idaho)

Direct or indirect alteration of Critical Habitat which appreciably diminishes the value of the habitat for both the survival and recovery of a listed species. Such alterations include, but are not limited to, alterations adversely modifying any of those physical or biological features that were the basis for determining the habitat to be critical.

A vessel in which carbon-containing biomass is reacted in water in absence of air to produce methane containing gas (biogas).

Installing a utility facility underground without encasement by plowing.

Electricity that flows continuously in one direction, as contrasted with alternating current (AC).

Determination of Non Significance

Environmental Coordination Procedures Act

The liquid discharge resulting from processing activities, usually containing residues from such use. Waste discharged into the environment, treated or untreated.

Energy Facility Siting Council, a council that coordinates and approves siting for large power plants.

Washington's Energy Facility Site Evaluation Council

Environmental Impact Statement 
EMISSIONS

ENVIRONMENTAL ASSESSMENT

ENVIRONMENTAL EFFECTS

ENVIRONMENTAL IMPACT STATEMENT (EIS)

EPA

EPIC

ER

ESP

ESSENTIAL HABITAT

ETHANOL (ETHYL ALCOHOL)
Substances discharged into the environment as waste material, such as discharge into the air from smokestacks, or discharge into the water from waste streams.

A concise public document for which a federal agency is responsible that serves to briefly provide sufficient evidence and analysis for determining whether to prepare an environmental impact statement or a finding of no significant impact; aid an agency's compliance with the Act when no environmental impact statement is necessary; facilitate preparation of a statement when one is necessary. Shall include brief discussions of the need for the proposal, of alternatives as required by section 102(2)(E), of the environmental impacts of the proposed action and alternatives, and a listing of agencies and persons consulted. Also referred to as EA or ER (environmental review).

Direct effects caused by the action and occur at the same time and place. Indirect effects, which are caused by the action and are later in time or farther time or farther removed in distance, but are still reasonably foreseeable. Indirect effects may include growth inducing effects and other effects related to induced changes in the pattern of land use, population density or growth rate, and related effects on air and water and other natural systems, including ecosystems. Effects and impacts are used in the CEQ regulations are synonymous. Effects includes ecological (such as the effects on natural resources and on the components, structures, and functioning of affected ecosystems), aesthetic, historic, cultural, economic, social, or health, whether direct, indirect, or cumulative. Effects may also include those resulting from actions which may have both beneficial and detrimental effects, even if on balance the agency believes that the effect will be beneficial.

A detailed written statement as required by section 102(2)(C) of the National Environmental Policy Act.

\section{U.S. Environmental Protection Agency}

Environmental Permit Information Center (WDOE)

See Environmental Assessment

Electrostatic precipitator

Criteria for identifying are the same as for Critical Habitat, the only difference being that the area has not been officially designated as Critical Habitat.

A flammable alcohol compound with the chemical formula $\mathrm{CH}_{3} \mathrm{CH}_{2} \mathrm{OH}$ formed during sugar fermentation by yeast. 
EXCAVATION

EXPRESSWAY

EXTRA HIGH VOLTAGE (EHV)

FEASIBILTTY STUDY

FEDERAL ENERGY

REGULATORY COMMISSION (FERC)

FEIS

FERC

FIXED COSTS

FONSI

FPA

FREEWAY

FRONTAGE ROAD

FS

FURNACE

FWS

GASOHOL

GENERATOR

GIGAWATT HOUR (GWh)
The controlled, scientific recovery of subsurface materials and information from a cultural property, through professionally applied archaeological techniques.

A divided arterial highway for through traffic with full or partial control of access and generally with grade separations at major intersections.

A term applied to voltage levels of transmission lines that are higher than the voltage levels commonly used. At present, electrical utilities consider EHV to be any voltage of 345,000 volts or higher. See ultrahigh voltages.

An investigation to develop a project and definitively assess its desirability for implementation.

An agency in the U.S. Department of Energy; regulates the interstate transfer of electrical energy.

Final Environmental Impact Statement

Federal Energy Regulatory Commission

Costs associated with plant investment, including debt service, interim replacement, and insurance.

Finding of No Significant Impact

Federal Power Act

A divided arterial highway providing access with selected public roads only by prohibiting crossings at-grade or direct private driveway connections. Includes interstate highway system.

A local street or road auxiliary to and located on the side of an arterial highway for service to abutting property and adjacent areas and for control of access.

U.S. Forest Service

Any device used to burn biomass materials to produce heat or process heat.

U.S. Fish and Wildlife Service

Registered trade name for a blend of 90 percent unleaded gasoline with 10 percent fermentation alcohol.

A machine that converts mechanical energy into electrical energy.

One million kilowatt hours (kWh) 
GROUNDWATER

gr/SCF

HABITAT

HAZARDOUS WASTE

HIGH PRESSURE, HIGH TEMPERATURE WATER BOILER

HIGHWAY, STREET, or ROAD

HISTORIC PRESERVATION

HISTORIC PROPERTY or HISTORIC RESOURCE

HOGGED FUEL

HUMAN ENVIRONMENT
The supply of water under the earth's surface, as contrasted to surface water.

Grains of pollutant per standard cubic foot of gas; a measure of dust particles in a gas stream following standard methods.

The place where an organism (plant or animal) lives. There are four major divisions of habitat, namely, terrestrial, freshwater, estuarine, and marine.

Any waste or combination of wastes which pose a substantial present or potential hazard to human health or living organisms. Such wastes can be non-degradable, persistent in nature, can be biologically magnified, lethal, or may otherwise cause detrimental cumulative effects.

A water boiler operating at pressure exceeding 160 psig or temperature exceeding $250^{\circ} \mathrm{F}$.

A general term denoting a public way for purposes of vehicular travel, including the entire area within the rightof-way.

Includes identification, evaluation, recordation, documentation, curation, acquisition, protection, management, rehabilitation, restoration, stabilization, maintenance, reconstruction, or any combination of the foregoing activities.

Any prehistoric or historic district, site, building, structure, or object included in, or eligible for inclusion in, the National Register. The term includes, for purposes of these regulations, artifacts, records, and remains that are related to and located within such properties. The term 'eligible for inclusion in the National Register' includes both properties formally determined as such by the Secretary of the Interior and all other properties that meet National Register listing criteria.

Wood waste such as sawdust, planer shavings, and wood chunks used for fuel purposes.

Interpreted comprehensively to include the natural and physical environment and the relationship of people with that environment. This means that economic or social effects are not intended by themselves to require preparation of an environmental impact statement. When an environmental impact statement is prepared and economic or social and natural or physical environmental effects are interrelated, then the environmental impact statement will discuss all of these effects on the human environment. 
IDFG

IDHW

IDL

IDLIS

IDPR

IDT

IDWR

INCINERATOR

INSTALLED CAPACITY

INTERRUPTIBLE ENERGY

INVENTORY

IOU

IPCO

IPUC

ISHPO

ITD

KILOWATT (kW)

kV

$\mathbf{k W}$
Idaho Department of Fish and Game

Idaho Department of Health and Welfare

Idaho Department of Lands

Idaho Department of Labor and Industrial Services

Idaho Department of Parks and Recreation

Idaho Department of Transportation

Idaho Department of Water Resources

Any device used to burn solid and combustible liquid residues or wastes in order to produce heat.

The total of the capacities shown on the nameplates of the generating units in a power plant.

Energy that can be curtailed at the purchaser's discretion.

A term used to refer to both a record of cultural resources known to occur within a defined geographic area, and the methods used in developing the record. Depending on intended applications for the data, inventories may be based on compilation and synthesis of previously recorded cultural resource data from archival, library, and other indirect sources; systematic examinations of the land surface and natural exposures of the subsurface (survey) for indications of past human activity as represented by artificial modifications of the land and/or the presence of artifacts; and the use of interviews and related means of locating and describing previously unrecorded or incompletely documented cultural resources, including those that may not be identifiable through physical examination.

Investor-owned Utility

Idaho Power Company

Idaho Public Utility Commission

Idaho State Historic Preservation Office

Idaho Transportation Department

One thousand watt hours (Wh)-the amount of electrical power produced or consumed by a one kilowatt unit for 1 hour.

Kilovolt

Kilowatt 
kWh

LAER

LCDC

LMA

LOAD

LOAD FACTOR

LOC

LUBA

MAJOR FEDERAL ACTION
Kilowatt hour

Lowest achievable emissions rate; sets emission limit for non-attainment areas.

Oregon Land Conservation Development Commission, state appointed commission to determine land use policy.

Appropriate Public land Management Agency (BLM, FS NPS, tribe).

The amount of power required at a given point or points in an electric system.

The ratio of the average load to the maximum load during a given period.

Local agencies

Oregon Land Use Board of Appeals; seven-member state body appointed to adjudicate land use disputes.

Actions with effects that may be major and which are potentially subject to federal control and responsibility. Major reinforces but does not have a meaning independent of significantly. Actions include the circumstance where the responsible officials fail to act and that failure to act is reviewable by courts or administrative tribunals under the Administrative Procedure Act or other applicable law as agency action.

Actions include new and continuing activities, including projects and programs entirely or partly financed, assisted, conducted, regulated, or approved by federal agencies; new or revised agency rules, regulations, plans, policies, or procedures; and legislative proposals. Actions do not include funding assistance solely in the form of general revenue sharing funds, distributed under the State and Local Fiscal Assistance Act of 1972, 31 U.S.C. 1221 et seq., with no federal agency control over the subsequent use of such funds. Actions do not include bringing judicial or administrative civil or criminal enforcement actions.

Approval of specific projects, such as construction or management activities located in a defined geographic area. Projects include actions approved by permit or other regulatory decision as well as federal and federally assisted activities.

Emissions exceed "significant" rates for non-attainment areas.

Montana Code Annotated 
MDA

MDC

MDFWP

MDHES

MDLI

MDNRC

MDSL

MDT

MEGAWATT (MW)

METHANE

MGWPCS

MILL RESIDUE

MITIGATION
Montana Department of Agriculture

Montana Department of Commerce

Montana Department of Fish, Wildlife, and Parks

Montana Department of Health and Environmental Sciences

Montana Department of Labor and Industry

Montana Department of Natural Resources and

Conservation

Montana Department of State Lands

Montana Department of Transportation

One thousand kilowatts $(\mathrm{kW})$ or one million watts $(\mathrm{W})$

An odorless, colorless, flammable gas that is the primary constituent of natural gas.

Montana Groundwater Pollutant Control System

Wood and bark residues produced in processing lumber.

Avoiding the impact altogether by not taking a certain action or parts of an action.

Minimizing impacts by limiting the degree or magnitude of the action and its implementation.

Rectifying the impact by repairing, rehabilitating, or restoring the affected environment.

Reducing or eliminating the impact over time by preservation and maintenance operations during the life of the action.

Compensating for the impact by replacing or providing substitute resources or environments.

MkWh

Million kilowatt-hours

MOA

MOU

MPDES

MPSC
Memorandum of Agreement

Memorandum of Understanding

Montana Pollutant Discharge Elimination System

Montana Public Service Commission 
MSHPO

MSW

MW

NAAQS

NAMEPLATE RATING
Montana State Historic Preservation Office

Municipal Solid Waste

Megawatt

National Ambient Air Quality Standards of the U.S. Environmental Protection Agency.

The full-load continuous rating of a generator or other electrical equipment under specified conditions as designated by the manufacturer, and written on the nameplate.

NATIONAL ENVIRONMENTAL An act, passed in 1969, requiring that the environmental POLICY ACT (NEPA) impact of most projects and programs be identified. Among its important provisions is one requiring a detailed statement of environmental impact of, and alternatives to, a project to be submitted to the federal government before the project can begin.

NATIONAL REGISTER OF HISTORIC PLACES

NEC

NEGATIVE DECLARATION

NEPA

NEPA PROCESS

NESHAPS

NEW UTILITY

INSTALLATIONS

NFIP

NFS

NGPA
The National Register of Historic Places, expanded and maintained by the Secretary of the Interior, as authorized by section 2(b) of the Historic Sites Act and section 101(a)(1)(A) of the National Historic Preservation Act. The National Register lists cultural properties found to qualify for inclusion because of their local, state, or national significance. Eligibility criteria and nomination procedures are found in 36 CFR Part 60. The Secretary's administrative responsibility for the National Register is delegated to the National Park Service.

National Electric Code

The document that satisfies the NEPA requirement if no significant environmental impacts would result from a project as determined by an initial study.

National Environmental Policy Act of 1969

All measures necessary for compliance with the requirements of section 2 and Title I of NEPA.

National Emission Standards for Hazardous Air Pollution

Initial installations on the highway right-of-way and the replacement of existing facilities with those of a different type, capacity, or design or replacement at a new location on the right-of-way.

National Flood Insurance Program

National Forest Service

National Gas Policy Act 
NMFS

NOC

NOI

NON-ATTAINMENT AREA

$\mathrm{NO}_{\mathrm{x}}$

NPDES

NPPC

NPS

NSPS

OACHP

OBCA

ODEQ

ODFW

ODLCD

ODOA

ODOE

ODOF

ODOGAMI

ODOT

ODPR

ODSL

OEFSC

OFF-PEAK

OFFSETS
National Marine Fisheries Service

Notice of Construction

Notice of Intent

A geographic area in which the quality of the air is worse than federal air pollution standards. PSD requirements do not apply in non-attainment areas.

Nitrogen oxides

National Pollution Discharge Elimination System, federal water quality program administered by the state agency responsible for water quality.

Northwest Power Planning Council

National Park Service

New Source Performance Standards, from EPA New Source Review for very large sources of air pollution.

Oregon Advisory Committee in Historic Preservation

Oregon Building Codes Agency

Oregon Department of Environmental Quality

Oregon Department of Fish and Wildlife

Oregon Department of Land Conservation and

Development

Oregon Department of Agriculture

Oregon Department of Energy

Oregon Department of Forestry

Oregon Department of Geology and Mineral Industries

Oregon Department of Transportation

Oregon Department of Parks and Recreation

Oregon Division of State Lands

Oregon Energy Facility Siting Council

The time of day and week when the demand for electricity is low; see on-peak.

Quantity of air pollutant borrowed from existing permit holder to "offset" pollutants from a new facility. 
OLCDC

ON-PEAK

OPACITY

OPUC

OUTAGE

OUTAGE, FORCED

OUTAGE, SCHEDULED

OUTPUT

OWRC

OWRD

PARTICULATES

PEAKING UNIT

PER

P.L.

PLANT FACTOR

POWER BOILER

PRESSURE VESSEL

PREVENTION OF

SIGNIFICANT

DETERIORATION (PSD)

PRODUCER GAS
Oregon Land Conservation and Development Commission.

The time of day and week when demand for electricity in a region is high.

The relative capacity of smoke or particles emitted into the air to obstruct the transmission of light.

Oregon Public Utility Commission

The period during which a facility is out of service.

The shutdown of a facility for emergency reasons.

The shutdown of a facility for inspection or maintenance, as scheduled.

The amount of power or energy delivered from a piece of equipment, a station, or a system.

Oregon Water Resources Commission

Oregon Water Resources Department

Fine solid particles which remain individually dispersed in stack emissions.

An auxiliary electric power system that is used to supplement the power supply system during periods of peak demand for electricity. Peaking units are usually low-cost, inefficient units having a high fuel cost, or hydroelectric units having low firm capacity.

Preliminary Environmental Review

Public Law

See capacity factor

An internally fired boiler which is primarily intended for temporary location, the construction and usage of which is obviously portable.

A boiler in which steam or other vapor generated at a pressure of more than 15 psig.

A planning and management process for air quality.

Fuel gas high in carbon monoxide $(\mathrm{CO})$ and hydrogen $\left(\mathrm{H}_{2}\right)$, produced by burning a solid fuel (biomass) with a deficiency of air or by passing a moisture of air and steam through a bed of solid fuel (biomass). 
PSD

PSI

PSIG

PUHCA

PURPA

PYROLYSIS

QF

QUAD

QUADRILLION Btu

RCRA

RCW

RDF

RENEWABLE ENERGY RESOURCE

RIGHT-OF-WAY

RIPARIAN RIGHTS

ROADWAY

ROD

ROYALTY
Prevention of significant deterioration

A unit of pressure as measured in pounds per square inch.

Pounds per square inch gauge

Public Utility Holding Company Act

Public Utility Regulatory Policies Act of 1978. This act requires utilities to purchase power from and interconnect with a privately developed facility and mandates the state utility regulatory agency to set a "just and reasonable price."

The breaking apart (destructive distillation) of complex molecules into simpler units by the use of heat. For purposes of this handbook, the process involves chemical decomposition of biomass to producer gas, fuel oil and charcoal.

Qualifying Facility

See Quadrillion Btu

An amount of energy equal to the heat value of 965 billion cubic feet of gas, 175 million barrels of oil (DOE), or 38 million tons of coal.

Resource Conservation and Recovery Act

Rivvised Code of Washington

Refuse derived fuel, combustible portion of municipal solid waste.

Any energy resource that can be replaced after use through natural means such as solar energy, wind energy, hydropower, and energy from growing plants.

A general term denoting land, property, or interest therein, usually in a strip, acquired for or devoted to transportation purposes.

The rights of land owners to the water on or bordering their property, including the right to prevent diversion or misuse of upstream water.

The portion of a highway, including shoulders, for vehicular use. A divided highway has two or more roadways.

Record of Decision

The portion of the proceeds paid to the title holder in exchange for development of a property. 
SBA

SCA

SCRUBBER

SCS

SELP

SEPA

SERP

SHPO

SIGNIFICANT EMISSIONS RATE

SIGNIFICANTLY
Small Business Administration

Site Certification Agreement

A device in which combustible or stack gas is cleaned by liquid spray.

Soil Conservation Service

Small-Scale Energy Loan Program; Oregon Department of Energy.

State Environmental Policy Act

Source Emission Reduction Plan

State Historic Preservation Office

Annual rate of emissions for specified pollutant that identifies a "major" air pollution source in DEQ regulations.

As used in NEPA requires considerations of both context and intensity:

1. Context. This means that the significance of an action must be analyzed in sevieral contexts such as society as a whole (human, national), the affected region, the affected interests, and the locality. Significance varies with the setting of the proposed action. For instance, in the case of a site-specific action, significance would usually depend upon the effects in the locale rather in the world as a whole. Both short- and long-term effects are relevant.

2. Intensity. This refers to the severity of impact. Responsible officials must bear in mind that more than one agency may make decisions about partial aspects of a major action. The following should be considered in evaluating intensity:

a. Unique characteristics of the geographic area such as proximity to historic or cultural resources, park lands, prime farmlands, wetlands, wild and scenic rivers, or ecologically critical areas.

b. The degree to which the effects on the quality of the human environment are likely to be highly controversial.

c. The degree to which the possible effects on the human environment are highly uncertain or involve unique or unknown risks. 


\section{SIP}

$\mathrm{SO}_{2}$

SOLID WASTÈ

SPININING RESERVE

SPP

SRC

STATE HISTORIC PRESERVATION OFFICER

SUI GENERIS

SURFACE WATER

SWITCHING STATION

SYNGAS

THERM

THERMAL PI ANT

THP

TIERING d. The degree to which the action may adversely affect an endangered or threatened species or its habitat that has been determined to be critical under the Endangered Species Act of 1973.

State Implementation Plan

Sulfur dioxide

All solid material considered to be useless, unwanted, or discarded by the person in possession of it. Solid in gaseous or liquid wastes that are in the process of treatment or reuse and naturally occurring rock and soil are not considered solid waste.

Generating capacity that is on-line in excess of the load on the system ready to carry additional electrical load.

Small power producer

State Regulatory Commission

The official in each state authorized by the state at the request of the Secretary of the Interior to act as a liaison for purposes of implementing the National Historic Preservation Act of 1966.

Unique unto itself

Water on the earth's surface that is exposed to the atmosphere such as rivers, lakes, oceans, as contrasted to groundwater.

An assemblage of equipment used for the sole purpose of tying together two or more electric circuits. Selectively arranged switches are used to permit a circuit to be disconnected in case of trouble, or to change electric connections between circuits. A type of substation.

Synthetic natural gas, high quality producer gas made by oxygen, pressure or catalytic gasification of biomass or fossil fuels.

The equivalent of $100,000 \mathrm{Btu}$

An electric generating plant that uses heat to produce electricity. Such plants may burn coal, gas, oil, biomass, or use nuclear energy to produce thermal energy.

Thecretical horsepower

The coverage of general matters in broader environmental impact statements (such as national prograre or policy statements) with subsequent narrower statements or en- 
TRADITIONAL LIFEWAY VALUE

TRANSFORMER

TRANSMISSION

TRIBE

TSP

UBC

UMC

ULTRAHIGH VOLTAGES (UHV)

UNIFORM BUILDING CODE

UNIFORM MECHANICAL CODE vironmental analyses (such as regional or basin wide program statements or ultimately site-specific statements) incorporating by reference the general discussions and concentrating solely on the issues specific to the statement subsequently prepared. Tiering is appropriate when the sequence of statements or analyses is: (a) from a program, plan, or policy environmental impact statement to a program, plan, or policy statement or analysis of lesser scope or to a site-specific statement or analysis; (b) from an environmental impact statement on a specific action at an early stage (such as need and site selection) or a subsequent statement or analysis at a later stage (such as environmental mitigation). Tiering in such cases is appropriate when it helps the lead agency to focus on the issues which are ripe for decision and exclude from consideration issues already decided or not yet ripe.

The quality of being useful in or important to the maintenance of a specified social and/or cultural group's traditional systems of religious belief, cultural practice, or social interaction, not closely identified with definite locations. Another group's shared values are abstract, nonmaterial, ascribed ideas that one cannot know about without being told. Traditional life way values are taken into account through public participation during planning and environmental analysis.

A device used to change the voltage of altemating current (AC) electricity.

The act or process of transporting electrical energy in bulk from a source or sources of supply to other principal parts of a system or to other utility systems.

Appropriate Indian tribe

Total suspended particulates

Uniform Building Code

Uniform Mechanical Code

Voltages greater than 765,000 volts. See extra high voltage (EHV).

Published by the International Conference of Building Officials. Covers the fire, life, and structural safety aspects of all building and related structures.

Sponsored by the Intemational Association of Plumbing and Mechanical Officials and the International Conference of Building Officials. Contains requirements for the installation and maintenance of heating, ventilating, cooling, and refrigeration systems. 
URBAN GROWTH

BOUNDARY (UGB)

USFS

USGS

UST

VISUAL QUALITY

VOC

WAC

WATERMASTER

WDCD

WDF

WDNR

WDOC

WDOE

WDOT

WDOH

WDTED

WDW

WEFSEC

WHEELING

WL\&I

WOAHP

WPCF
Boundary around cities that provides for future expansion into a county.

U.S. Forest Service

U.S. Geological Survey

Underground storage tank

Shall mean those desirable characteristics of the appearance of the facility and its environment, such as harmony between or blending of natural and manmade objects in the environment, continuity of visual form without distracting interruptions, and simplicity of designs which are desirably functional in shape.

Volatile organic compounds

Washington Administrative Code

Employed by Oregon Water Resources Department, allocates available surface or groundwater in state.

Washington Department of Community Development

Washington Department of Fisheries

Washington Department of Natural Resources

Washington Department of Commerce

Washington Department of Ecology

Washington Department of Transportation

Washington Department of Health

Washington Department of Trade \& Economic Development

Washington Department of Wildlife

Washington Energy Facility Site Evaluation Council

The transportation of electricity by an electric utility over its lines for another utility.

Washington Department of Labor \& Industries

Washington Office of Archaeological and Historic Preservation

Water Pollution Control Facility 
WPPSS

WSEO

WUTC
Washington Public Power Supply System

Washington State Energy Office

Washington Utilities and Transportation Commission 


\section{Federal Agencies}

Air Quality

Environmental Protection Agency (EPA), Region X 1200 Sixth Avenue

Seattle, WA 98101

(206) 442-1275

Region 8 (Montana)

Environmental Protection Agency

999 18ia Street, Suite 500

Denver, CO 80202-2405

(303) 293-1603

\section{Regional Offices}

EPA Operations Office

c/o State Department of Ecology

PV-11

Olympia, WA 98504

(206) 459-6000

Idaho Department of Health \& Welfare

Bureau of Air Quality

1410 N Hilton

Boise, ID 83706

(208) 334-5898

\section{Bonneville Power Administration}

P.O. Box 3627

Portland, OR 97208

(503) 230-3000

\section{Bureau of Indian Affairs}

Director

P. O. Box 10

Phoenix, AZ 85011

(602) 379-6600

Columbia River Intertribal Fishery Commission

975 SE Sandy Boulevard, Suite 202

Portland, OR 97214

(503) 238-0667

\section{Bureau of Land Management}

State Offices

Idaho

Bureau of Land Management

3380 Americana Terrace

Boise, ID 83706

(208) 334-1414
EPA, Region I (Idaho, Oregon, Washington)

911 NE 11th Avenue

Portland, OR 97232-4181

(503) 231-6159

Oregon Department of Environmental Qualities

81 i SW 6th

Portland, OR 97204

(503) 229-5630

$1-800-452-4011$
Director

911 NE 11 th Avenue

Portland, OR 97232-4169

(503) 231-6702
Oregon (Washington)

Bureau of Land Management

825 NE Multnomah

P.O. Box 2965

Portland, OR 97208

(503) 231-6281 
Montana (No. Dakota, So. Dakota, Minnesota)

Bureau of Land Management

222 N 32nd Street

P.O. Box 26800

Billing, MT 59107

(406) 255-2885

District Offices

Baker Resource Area

P.O. Box 987

Baker, OR 97814

(503) 523-6391

Klamath Falls Resource Area

2795 Anderson Avenue, Suite 25

Klamath Fa!ls, OR 97603-7891

(503) 883-6916

Burns District

HC 74-12533 Highway $20 \mathrm{~W}$

Medford District

Hines, OR 97738

3040 Biddle Road

Medford, OR 97501

Coos Bay District

1300 Airport Lane

(503) $770-2200$

North Bend, OR 97459

Prineville District

(503) 756-0100

185 E 4th Street

P.O. Box 550

Eugene District

Prineville, OR 97754

1255 Pearl Street

P.O. Box 10226

Eugene, OR 97401

(503) 683-6600

(503) 447-4115

Roseburg District

777 NW Garden Valley Boulevard

Roseburg, OR 97470

Salem District

1717 Fabry Road SE

(503) 672-4491

Salem, OR 97306

Vale District

(503) 399-5646

100 Oregon Street

Vale, OR 97918

(503) 473-3144

Spokane District

E 4217 Main

Wenatchee Resource Area

Spokane, WA 99202

$133 \mathrm{~N}$ Western Avenue

(509) 353-2570

Wenatchee, WA 98801

Tillamook Resource Area

(509) 662-4223

6615 Officer's Row

Tillamook, OR 97141

(503) 842-7546

Bureau of Land Management, Board of Land Appeals

Office of Hearings and Appeals

Arlington, VA 22203 
Bureau of Reclamation

Regional Director

Pacific Northwest Region

Bureau of Reclamation

Box 043

550 W Fort Street

Boise, ID 83724-(1043

(208) 334-1905

\section{Corps of Engineers}

District Engineer

U.S. Army Engineer District

Walla Walla, WA 99362

(509) 522-6720

\section{Field Offices}

Corps of Engineers

Lucky Peak Project Office

HC-33, Box 1020

Boise, ID 83706

(208) 34/3-0671

Corps of Engineers

P.O. Box 2946

Portland, OR 97208-2946

(503) 326-6995

Environmental Protection Agency

Environmental Impact Review Officer

Environmental Protection Agency-Region X

1200 Sixth Avenue

Seattle, WA 98101

(206) 442-1200

Federal Aviation Administration

Washington \& Oregon Regional Office 3105 Airport Way

Boise, ID 83705

(208) 334-1642

Flight Standards District Office

FAA Building

Helena Regional Airport

Helena, MT 59601

(406) 449-5434

Federal Communications Commission

Washington, Oregon, Idaho, \& Montana

Building A

11410 NE 122nd Way, Suite 312

Kirkland, WA 98034

(206) 821-9037
Corps of Engineers

c/o Forest Service

1201 Ironwood Drive

Coeur d' Alene, ID 83814

(208) 765-7237

Corps of Engineers (Montana)

215 N 17th Street

Omaha, NE 68102

(402) $22.1-4125$
Boise Airport Traffic Control Tower 1601 Lind Avenue SW

Renton, WA 98055

(206) 227-2001 
Fish and Wildlife Service

Region I

U.S. Fish and Wildlife Service

911 NE 11 th Avenue

Portland, OR 97232-4181

(503) 231-6159

\section{Regional Offices}

U.S. Fish and Wildlife Service

Boise Field Office

4696 Overland Road, Room 576

Boise, ID 83705

(208) 334-1931

U.S. Fish and Wildlife Service

Montana Regional Office

P.O. Box 25486

Denver Federal Center

Denver, CO 82225

(303) 236-7920

U.S. Fish and Wildlife Service

Olympia Field Office

3704 Griffin Lane, Suite 102

Olympia, WA 98501

(206) 753-9440

U.S. Fish and Wildlife Service

Portland Field Office

2600 SE 98 th Avenue, Suite 100

Portland, OR 97266

(503) 231-617

National Forest Service

Intermountain Region

U.S. Forest Service

Intermountain Region

324 25th Street

Ogden, UT 84401

(801) 625-5149

\section{Northern Region}

U.S. Forest Service

Northern Region

Federal Building

P.O. Box 7669

Missoula, MT 59807

(406) 329-3518

\section{National Forest Supervisors' Ofifices \\ Colville \\ Federal Building \\ 695 S Main Street \\ Colville, WA 99114 \\ (509) 684-3711}

Deschutes

1645 Highway $20 \mathrm{E}$

Bend, OR 97701

(503) 388-2715

Fremont

$524 \mathrm{~N}$ "G" Street

P.O. Box 551

Lakeview, OR 97630

(503) 947-2151

Gifford Pinchot

6926 E 4th Plain Boulevard

P.O. Box 8944

Vancouver, WA 98688-8944

(206) 696-7500

Siskiyou

200 NE Greenfield Road

P.O. Box $\$ 40$

Grants Pass, OR 97526

(503) 479-5301

Siuslaw

4077 Research Way

P.C. Box 1148 (97339)

Corv.lllis, OR 973.33

(503) 757-4480

Umatilla

Malheur

139 NE Dayton Street

John Day, OR 97845

(503) 575-1731

2517 SW Hailey Avenue

Pendleton, OR 97801

(503) 276-3811 
Mt. Baker-Snoqualmie

1022 First Avenue

Seattle, WA 98104

(206) 442-5400

Mt. Hood

2955 NW Division

Gresham, OR 97030

(503) 666-0700

Ochoco

155 N Court Street

P.O. Box 490

Prineville, OR 97754

(503) 447-6247

Okanogan

1240 2nd Avenue $S$

P.O. Box 950

Okanogan, WA 98840

(509) 422-2704

Olympic

P.O. Box 2288

Olympia, WA 98507

(206) 753-9534

Rogue River

$333 \mathrm{~W} 8 \mathrm{th}$ Street

P.O. Box 520

Medford, OR 97501

(503) 776-3600

National Park Service

Regional Director

Pacific Northwest Region

National Park Service

Attn: Regional Environmental Coordinator

83 S King Street, Suite 212

Seattle, WA 98104

(206) 442-5565

Ofrice of Environmental Project Review Department of the Interior

Associate Solicitor

Office of Environmental Affairs

Division of Energy and Resources

Office of the Solicitor

Washington, DC 20240

Northwest Power Planning Council

851 SW 6th, Suite 1100

Portland, OR 97204-1348

1-800-222-3355 (503) 222-5161
Umpqua

2900 NW Stewart Parkway

P.O. Box 1008

Roseburg, OR 97470

(502) 672-6601

Wallowa-Whitman

1550 Dewey Avenue

P.O. Box 907

Baker, OR 97814

(503) 523-6391

Wenatchee

301 Yakima Street

P.O. Box 811 (98807-0811)

Wenatchee, WA 98801

(509) 662-4335

Willamette

211 E 7th Avenue

P.O. Box 10607 (97440)

Eugene, OR 9740

(503) 687-65211

Winema

2819 Dahlia Street

Klamath Falls, OR 97601

(503) 883-6714
Department of the Interior

Regional Environmental Officer

Oregon, Washington, Idaho

911 NE 11th Avenue

Portland, OR 97232-4181

(503) 231-6157 


\section{Federal and State Offices - Idaho}

\section{Federal Agencies to Contact for Geothermal Development}

Bonneville Power Administration

P.O. Box 3627

Portland, OR 97208

(503) $230-3000$

Fish and Wildlife Service

U.S. Fish and Wildlife Service

Boise Field Office

4696 Overland Road, Room 576

Boise, ID 83705

(208) 334-1931

Forest Service

Northern Region

U.S. Forest Service

Clearwater National Forest

Federal Building

P.O. Box 7669

Missoula, MT 59807

(406) 329-3511

12730 Highway 12

Orofino, ID 83544

(208) 476-4541

Nez Perce National Forest

Route 2, Box 475

Grangeville, ID 83530

(208) 983-11963

Panhandle National Forest

1201 Ironwood Drive

Coeur d'Alene, ID 83814

(208) 765-7223

Bitterroot National Forest

316 N 3rd Street

Hamilton, MT 59840

(406) 363-3131

Intermountain Region

U.S. Forest Service

Boise National Forest

324 25th Street

Ogden, UT 84401

1750 Front Street

(801) 625-5431

Boise, ID 83702

(208) $364-4100$

Caribou National Forest

250 S 4th Avenue, Suite 294

Pocatello, ID 83201

(208) 236-7500

Challis National Forest

H/C 63, Highway 93

P.O. Box 1671

Challis, ID 83226

(208) 879-2285

Payette National Forest

P.O. Box 1026

Salmon National Forest

McCall, ID 83638

P. O. Box 729

(208) 634-1333

Salmon, ID 83467

(208) 756-2215

Sawtooh National Forest

2647 Kimberly Road E

Twin Falls, ID 83301

(208) 737-3200 
Targhee National Forest

420 N Bridge Street

P.O. Box 208

St. Anthony, ID 83445

(208) 624-3151

Bureau of Land Management

U.S. Bureau of Land Management

3380 Americana Terrace

Boise, ID 83706

(208) 334-1414

District Offices

Boise District Office

3948 Development Avenue

Boise, ID 83705

(208) 334-1582

Idaho Falls District Office

940 Lincoln Road

Idaho Falls, ID 83401

(208) 529-1020

Shoshone District Office

P. O. Box 2-B

Shoshone, ID 83352

(208) 886-2206

Burley District Office

Route 3, Box 1

Burley, ID 83318

(208) 678-5514

Salmon District Office

P. O. Box 430

Salmon, ID 83467

(208) $756-5400$

Coeur d'Alene District Office

1808 N 3rd Street

Coeur d'Alene, ID 83814

(208) 765-1511

Office of Environmental Project Review

Department of the Interior

Office of Environmental Affairs

$911 \mathrm{NE} 11$ th Avenue

Portland, OR 972324181

(503) 231-6157

Bureau of Reclamation

Pacific Northwest Region

Bureau of Reclamation

Box 043

$550 \mathrm{~W}$ Fort Street

Boise, ID 83724-0043

(208) 334-1905

Corps of Engineers

District Engineer

U.S. Army Engineer District

Walla Walla, WA 99362

(509) 522-6720 
Idaho Field Offices

Corps of Engineers

Lucky Peak Project Office

HC-33, Box 1020

Boise, ID 83706

(208) 343-0671

National Park Service

Regional Director

Pacific Northwest Region

National Park Service

Attn: Regional Environmental Coordinator

83 S King Street, Suite 212

Seattle, WA 98104

(206) 442-5565

Environmental Protection Agency

Environmental Impact Review Officer

Environmental Protection Agency-Region X 1200 Sixth Avenue

Seattle, WA 98101

(206) 442-1200

\section{Bureau of Indian Affairs}

Director

P. O. Box 10

Phoenix, AZ 85011

(602) 379-6600

Columbia River Intertribal Fishery Commission

975 SE Sandy Boulevard, Suite 202

Portland, OR 97214

(503) 238-0667

Federal Aviation Administration

Boise Airport Traffic Control Tower

3105 Airport Way

Boise, ID 83705

(208) 334-1642

\section{State Agencies to Contact for}

Geothermal Development

\section{Water Resources}

Idaho Department of Water Resources

Statehouse Mail

1301 N Orchard Street

Boise, ID 83720

(208) 327-7900
Corps of Engineers

c/o Forest Service

1201 Ironwood Drive

Coeur d'Alene, ID 83814

(208) 765-7237
Director

911 NE 11 th Avenue

Portland, OR 97232-4169

(503) 231-6702 
Regional Offices of Water Resources Northern Region

1910 NW Boulevard, Suite 210

Coeur d'Alene, ID 83814

(208) 765-4639

Eastern Region

150 Shoup, Suite 15

Idaho Falls, ID 83402

(208) 525-7161

Department of Fish and Game

Idaho Department of Fish and Game

$600 \mathrm{~S}$ Walnut Street

P. O. Box 25

Boise, ID 83707

(208) 334-3771

\section{Regional Offices}

Region 1

2320 Government Way

Coeur d'Alene, ID 83814

(208) 765-3111

Region 3

$109 \mathrm{~W}$ 44th Street

Boise, ID 83714

(208) 327-7025

\section{Region 4}

868 E Main

P O. Box 428

Jerome, ID 83338

(208) 324-4359

\section{Region 6}

1515 Lincoln Road

Idaho Falls, ID 83401

(208) 525-7290

Department of Parks and Recreation Idaho Department of Parks and Recreation Statehouse Mail

Boise, ID 83720

(208) 334-2154

Public Utilities Commission Idaho Public Utilities Commission $472 \mathrm{~W}$ Washington

Boise, ID 83702

(208) 334-0300
Southern Region

222 Shoshone Street E

Twin Falls, ID 83301

(208) 734-3578

Western Region 2735 Airport Way

Boise, ID 83705

(208) $334-2190$
Region 2

1540 Warner Avenue

Lewiston, ID 83501

(208) 743-6502

McCall Subregion

P. O. Box 905

McCall, ID 83638

(208) 634-8137

\section{Region 5}

1345 Barton Road

Pocatello, ID 83204

(208) 232-4703

Salmon Subregion

P. O. Box 1336

Salmon, ID 83467

(208) 756-2271 
Idaho State Historic Preservation Ofifice Idaho State Historical Society

210 Main Street

Boisc, ID 837(1)2

(208) 3.34-3847

Department of Health and Welfare

Division of Environmental Quality

Department of Health and Welfare

1410 N Hilton, Suite 101

Boise, ID 83720

(208) 334-5867

\section{Field Offices}

Coeur d'Alene Field Office

2110 Ironwood Parkway

Coeur d'Alene, ID 83814

(208) 667-3524

Pocatello Field Office

224 S Arthur

Pocatello, ID 83204

(208) 236-6160

\section{Department of Lands}

Idaho Department of Lands

Statehouse Mail, Room 121

Boise, ID 83720

(208) 334-3280

Department of Labor and Industrial Services

Statehouse Mail

277 N 6th

Boise, ID 83720

(208) 334-3950

\section{Transportation Department}

Idaho Transportation Department

P. O. Box 7129

Boise, ID 83707

(208) 334-8000
Lewiston Field Office

1118 F Street

Lewiston, ID 83501

(208) 799.3430

Twin Falls Field Office

P. O. Box 1626

Twin Falls, ID 83303

(208) 734-9520 
Montana State Agencies

Department of Natural Resources

and Conservation

Cogswell Building

1520 E Sixth Avenue

Helena, . . 59620

(406) 444-6699

Building Codes Bureau

1218 E Sixth Avenue

Helena, MT 59620

(406) 444-3494

Department of Commorce

1424 Ninth Avenue

Helena, MT 59620

(406) 444-3494

Board of Natural Resour and Conservation

Cogswell Building

1520 E Sixth Avenue

Helena, MT 59620

(406) 444-6699

Department of Health \&.

Environmental Sciences

Cogswell Building

1520 E Sixth Avenue

Helena, MT 59620

(406) 444-3948

Water Rights Bureau

Field Offices

Bozeman

$111 \mathrm{~N}$ Tracy

Bozeman, MT 59715

(406) 586-3136

Missoula

Holiday Village Professional Plaza

Suite 105

P.O. Box 5004

Missoula, MT 59806

(406) 721-4284

Helena

1520 E Sixth Avenue

Helena, MT 59620

(406) 444-6695

Kalispell

3220 Highway $93 \mathrm{~S}$

P.O. Box 860

Kalispell, MT 59903-0860

(406) 752-2288

\section{Havre}

$1708 \mathrm{~W}$ 2nd Street

P.O. Box 1828

Harve, MT 59501

(406) 265-5516

Glasgow

839 1st Avenue S

P.O. Box 1269

Glasgow, MT 59230

(406) 228-2561 
Lewistown

204 S Daws

P.O. Box 438

Lewistown, MT 59457

(406) 5.38-7459

Billings

1537 Avenue D, Suite 105

Billings, MT 59102

(406) 657-2105

State Historic Preservation Office

Montana Historical Society

225 N Roberts

Helena, MT 59620

(406) 444-7715

Department of State Lands

1625 Eleventh Avenue

Helena, MT 59620

(406) 444-2074

Board of Land Commissioners

1625 Eleventh Avenue

Helena, MT 59620

(406) 444-2074

Department of Fish, Wildife, and Parks

1420 E Sixth Avenue

Helena, MT 59620

(406) 444-3186

Department of Transportation

2701 Prospect Avenue

Helena, MT 59620

(406) 444-6201

Department of Labor and Industry

Lockey and Roberts

Heiena, MT 5962n

(406) 444-3555
Miles City

$5 \mathrm{~N}$ Prairie Avenue

P.O. Box 276

Miles City, MT 59301

(406) 232-6359 


\section{Oregon Addresses}

Building Codes Agency

1535 Edgewater NW

Salem, Oregon 97310

(503) 373-1248

(503) $378-3290$

Fire Marshall

3000 Market Street NE, Suite 534

Salem, Oregon 97310

(503) 378-4580

Boiler Inspection \& Licensing

Building Codes Agency

1535 Edgewater Road NW

Salem, OR 97310

(503) 378-3290

Energy Facility Siting Council

Department of Energy

625 Marion NE

Salem, Oregon 97310

(503) 378-4129

Public Utility Commissioner

Utilities Program

Labor \& Industries Building, Room 330

Salem, Oregon 97310

(503) 378-6634

Oregon Water Resources Department

3850 Portland Road NE

Salem, Oregon 97310

(503) 378-3739

Water Resources Department

3850 Portland Road NE

Salem, OR 97310

(503) 370-3739

Department of Geology and Mineral Industries

910 State Office Building

1400 SW 5th

Portland, OR 97201

(503) 229-5580

Department of Environmental Quality

811 SW Sixth

Portland, OR 97204

(503) 229-5696 
Department of Fish and Wildlife

2501 SW First Avenue

Box 59

Portland, OR 97207

(503) 229-5400

Economic Development Department

775 Summer Street NE

Salem, OR 97310

(503) 373-1200

* Department of Agriculture

Plant Conservation Biology Program

625 Capitol Street NE

Salem, OR 97310-0110

(503) $378-3810$

Columbia River Gorge Commission

288 E Jewett Boulevard

Box 730

White Salmon, WA 98672

(509) 493-3323

Oregon Department of Energy

625 Marion Street NE

Salem, OR 97310

(503) $378-4040$

Oregon Parks and Recreation Department

Vick Building

525 Trade Street SE \#301

Salem, OR 97310

(503) 378-6305

Advisory Committee on Historic Preservation 525 Trade Street SE

Salem, OR 97310

(503) 378-5001

Oregon Department of Forestry

State Board of Forestry

2600 State Street

Salem, OR 97310

(503) 378-2511

Oregon Department of Transportation

Oregon Transportation Commission

135 Transportation Building

Salem, OR 97310

(503) 378-6388 
Oregon Division of State Lands

State Land Board

775 Summer Street

Salem, OR 97310

(503) 378-3850

Oregon Water Resources Department District Offices

\section{District}

1

3

4

5

6

7

8

9

10
Lane, Linn

Hood River, Sherman, Wasco

Baker

\section{Counties}

Clatsop, Columbia, Tillamook, Washington

Gilliam, Grant, Wheeler

Morrow, Umatilla

Union

Wallowa

Malheur

Harney
Address

Washington County Courthouse

$155 \mathrm{~N}$ 1st Avenue

Hillsboro, OR 97123

(503) 681-7018

Lane County Courthouse

Environmental Health Department $125 \mathrm{E}$ 8th

Eugene, OR 97401

(503) 687-4011

Wasco County Courthouse Annex

A 400 E 5th

The Dalles, OR 97058

(503) 296-5494

P.O. Box 261

Canyon City, OR 97820

575-0119

3920 Westgate

Pendleton, OR 97801

276-7111

Route 1, Box 1709

La Grande, OR 97850

(503) 963-1010

Wallowa County Courthouse

Enterprise, OR 97828

426-4216

Baker County Courthouse 1995 3rd Street

Baker, OR 97814

(503) 523-8224 or 523-7866

Malheur County Courthouse

Vale, OR 97918

(503) 473-5130

Harney County Courthouse

P.O. Box 1147

Burns, OR 97720

(503) 573-2591 
11

Crook, Deschutes,

Jefferson

12

Lake

13

Jackson

14

Josephine

15

16

17

18
Coos, Curry, Douglas

Clackamas, Marion, Multnomah

Klamath

Benton, Lincoln, Polk, Yamhill
117 E NW Lafayette

Bend, OR 97701

(503) 388-6669

513 Center Street

Lakeview, OR 97630

(503) 947-6038

Jackson County Courthouse

10 S Oakdale, Room 106

Medford, OR 97501

(503) 776-7056

Grants Pass Municipal Building 101 NW "A" Street

Grants Pass, OR 97526

(503) 474-5385

Justice Building, Room 103

Roseburg, OR 97470

(503) 440-4255

3850 Portland Road NE

Salem, OR 97310

(503) $378-8128$

3328 Vandenberg Road Klamath Falls, OR 97603

(503) 883-4182

3850 Portland Road NE

Salem, OR 97310

(503) 378-8128

Oregon County Planning Departments

County
Baker
Benton
Clackamas
Clatsop
Columbia
Coos
Crook
Curry

Deschutes

Douglas

Gilliam

Grant

Harney

Hood River

Jackson

Jefferson

Josephine
County Seat

Baker City

Corvallis

Oregon City

Astoria

St. Helens

Coquille

Prineville

Gold Beach

Bend

Roseburg

Condon

Canyon City

Burns

Hood River

Medford

Madras

Grants Pass
Telephone

523-6414

757-6819

655-8521

325-8611

397-1501

396-3121

447-3211

247-7011

388-6556

672-3311

384-4243

575-1519

573-6655

386-1306

776-7554

475-2317

474-5421 
Klamath

Lake

Lane

Lincoln

Linn

Malheur

Marion

Morrow

Multnomah

Polk

Sherman

Tillamook

Umatilla

Union

Wallowa

Wasco

Washington

Wheeler

Yamhill
Klamath Falls

Lakeview

Eugene

Newport

Albany

Vale

Salem

Irrigon

Portland

Dallas

Moro

Tillamook

Pendleton

La Grande

Enterprise

The Dalles

Hillsboro

Fossil

McMinnville
882-2501

947-4494

687-4061

265-6611

967-3816

473-3185

588-5038

676-9061

248-3043

623-9237

565-3606

842-5511

276-7111

963-1014

426-3048

298-5169

648-8761

763-2911

472-9371 


\section{Washington State Agency Addresses}

Washington Department of Natural Resuurces

201 John A. Cherberg Building

QW-2.1

Olympia, WA 98504

(206) 753-5327

Geology \& Earth Resources Division

4224 Sixth Avenue SE

Rowe Six Building, PY-12

Lacey, WA 98503

(206) 459-6372

Forest Regulation \& Assistance

$1007 \mathrm{~S}$ Washington, EL-03

Olympia, WA 98504

(206) 753-5315

Regional Offices

Central Region

1405 Rush Road S-3

Chehalis, WA 98532

(206) 753-3410

Northeast Region

P.O. Box 190

Colville, WA 99114

(509) 684-5201

Northwest Region

919 N Township Street

Sedro Woolley, WA 98284

(206) 856-0083

Olyinpic Region

Route 1, Box 1375

Forks, WA 98331

(206) 374-6131

South Puget Sound Region

Southeast Region

28329 SE 448th Street

713 E Bowers Road

Enumclaw, WA 98022

Ellensburg, WA 98926

(206) 825-1631

(509) 925-6131

Southwest Region

601 Bond Road

Castle Rock, WA 98611

(206) $577-2025$

Washington State Energy Orfice

809 Legion Way SE, FA-11

Olympia, WA 98504

Department of Ecology

Main Office

PV-11

Olympia-Lacey, WA 98504

(206) 459-6000

Regional Offices

Eastern

N 4601 Monroe, Suite 100

Spokane, WA 99205-1295

Central

$3601 \mathrm{~W}$ Washington

Yakima, WA 98903-1164

(509) 456-2926

(509) 575-2800 
Department of Fisheries

115 General Administration Building

AX-11

Olympia, WA 98504

(206) 753-6600

Parks and Recreation Commission

600 N Capitol Way, GJ-11

Olympia, WA 98504

(206) 753-5755

Department of Social and Health Services

Environmental Health Division

Mail Stop LD-11

Olympia, WA 98504

(206) 753-5955

Department of Wildlife

600 Capitol Way N

GJ-11

Olympia、WA 98501-1091

(206) 753-5700

Energy Facility Site Evaluation Council

809 Legion Way SE

FA-11

Olympia, WA 98504-1211

(206) $956-2000$

Air Quality

Department of Social and Health Services

Twelfth \& Franklin, OB-22

Olympia, WA 98504

(206) 753-7039

Puget Sound Air Pollution Control Agency

200 W Mercer Street, Room 205

Seattle, WA 98119-3958

(206) 296-7330

Spokane County Air Pollution Control Authority

W 1101 College Avenue, Room 230

Spokane, WA 99201

(509) 456-4727

Grant County Clean Air Authority

P.O. Box 37

Ephrata, WA 98823

(509) 754-4313

NW Regional Office (San Juan County

4350150 th Avenue NE

Redmond, WA 98052-5301

(206) $867-7100$
Olympic Air Pollution Control Authority

120 E State Avenue

Olympia, WA 98502

(206) $352-4881$

Southwest Air Pollution Control Authority 1308 NE 134th Street, Suite D

Vancouver, WA 98685

(206) 574-3058

Yakima County Clean Air Authority

209 County Courthouse

North Second \& East B Street

Yakima, WA 98901

(509) 575-4116

Air Pollution Control Authority 650 George Washington Way

Richland, WA 99352

(509) 545-2354 
Omice of Archaeological and Historic Preservation $111 \mathrm{~W} 21$ st Avenue

KL-11

Olympia, WA 98504

(206) 753-4011

U.S. Forest Service

1835 Black Lake Boulevard SW

Olympia, WA 98502

(206) 956-2306 


\section{Indian Tribes of the Northwest}

Idaho Indian Tribes

Chairman

Nez Perce Executive Committee

Nez Perce Tribe

P. O. Box 305

Lapwai, ID 83540

(208) 843-2253

Shoshone-Bannock Tribe

P. O. Box 306

Fort Hall, ID 83203

(208) 238-3700

Montana Indian Tribes

Assiniboine and Sioux Tribes

Fort Peck Agency

P.O. Box 1027

Poplar, MT 59255

(406) 768-5155

Confederated Salish \& Kootenai Tribes

P.O. Box 278

Pablo, MT 59855

(406) 657-2700

Fort Belknap Community Council

P.O. Box 249

Harlem, MT 59526

(406) 353-2205

Chippewa Cree Tribe

Rocky Boy's Agency

Rocky Boy Route, Box 544

Box Elder, MT 59521

(406) 395-4478

\section{Oregon Indian Tribes}

Confederated Tribes of Coos,

Lower Umpqua, \& Sluslaw Indians

$455 \mathrm{~S}$ 4th Street

Coos Bay, OR 97420-1570

(503) 267-5454

Coquille Indian Tribe

P.O. Box 1435

Coos Bay, OR 97420-0330

(503) 267-5454
Shoshone-Paiute Tribe of the

Duck Valley Reservation

P. O. Box 219

Owyhee, NV 89832

(702) 757-3211

Coeur d'Alene Tribal Headquarters

Sub-Agency

Plummer, ID 83851

(208) 274-3101

Blackfeet Nation

P.O. Box 846

Browning, MT 59417

(406) 338-7179

Crow Tribal Council

Box 159

Crow Agency, MT 59022

(406) 638-2601

Northern Cheyenne Tribal Council

P.O. Box 128

Lame Deer, MT 59043

(406) 477-6284
Confederated Tribes of the Grand Ronde Community of Oregon

P.O. Box 38

Grand Ronde, OR 97347-0038

(503) 879-5215

Cow Creek Band of Umpqua Tribe

2400 Stewart Parkway, Suite 300

Roseburg, OR 97470-1563

(503) 672-9405 
Siletz Tribal Council

P.O. Box 549

Siletz, OR 97380-0549

(503) 444-2532

Confederated Tribes of Warm Springs

H.C. 71

100 Pasigo Street

Burns, OR 97720-9303

(503) 573.2088

Washington Indian Tribes

Chehalis Confederated Tribes

P.O. Box 536

Oakville, WA 98568

(206) 273-5911

Hoh Tribe

HC 80 Box 917

Forks, WA 98331

(206) 374-6582

Kalispel Tribe

P.O. Box 38

Usk, WA 99180

(509) 445-1147

Lummi Tribe

2616 Kwina Road

Bellingham, WA 98226-9298

(206) 643-6242

Muckleshoot Tribe

39015 172nd Avenue SE

Auburn, WA 98002

(206) 939-3311

Nooksack Tribe

P.O. Box 157

Deming, WA 98244

(206) $592-5170$

Puyallup Tribe

2002 E 28th Street

Tacoma, WA 98404

(206) 597-6200

Quinault Tribe

P.O. Box 189

Taholah, WA 98587

(206) 276-8211
Umatilla Tribe

P.O. Box 638

Pendleton, OR 97801-0638

(503) 276-3165
Colville Confederated Tribes

P.O. Box 150

Nespelem, WA 99155

(509) 634-4763

Jamestown Klallam Tribe

305 Oly Blyn Highway

Sequim, WA 98382

(206) 683-1109

Lower Elwha Klallam Tribe

1666 Lower Elwha Road

Port Angeles, WA 98362-0298

(206) 452-8471

Makah Tribe

P.O. Box 115

Neah Bay, WA 98357

(206) 645-2205

Nisqually Tribe

4820 She-Nah-Num D. SE

Olympia, WA 98503

(206) 456-5221

Port Gamble Klallam Tribe

P.O. Box 280

Kingston, WA 98346

(206) 297-2646

Quileute Tribe

P.O. Box 279

La Push, WA 98350

(206) 374-6143

Sauk-Sueittle Tribe 5318 Chief Brown Lane

Darrington, WA 98241

(206) 436-0132 
Shoalwater Bay Tribe

P.O. Box 597

Tokeland, WA 98590

(206) 267-6766

Spokane Tribe

P.O. Box 100

Wellpinit, WA 99040

(509) 258-4591

Stillaguamish Tribe

3439 Stoluckguamish Lane

Arlington, WA 98223

(206) 435-2755

Swinomish Tribe

P.O. Box 817

LaConner, WA 98257

(206) 466-3163

Upper Skagit Tribe 2284 Community Plaza

Sedro Woolley, WA 98284

(206) 856-5501
Skokomish Tribe

N 541 Tribal Center Road

Shelton, WA 98584

(206) 877-5213

Squaxin Island Tribe

W 81 Highway 198

Shelton, WA 98584

(206) 426-9783

Suquamish Tribe

P.0. 498

Suquamish, WA 98392

(206) 598-3311

Tulalip Tribes

6700 Totem Beach Road

Marysville, WA 98270-9694

(206) 653-0223

Yakima Confederated Tribes

P.O. Box 151

Toppenish, WA 98948

(509) 865-5121 

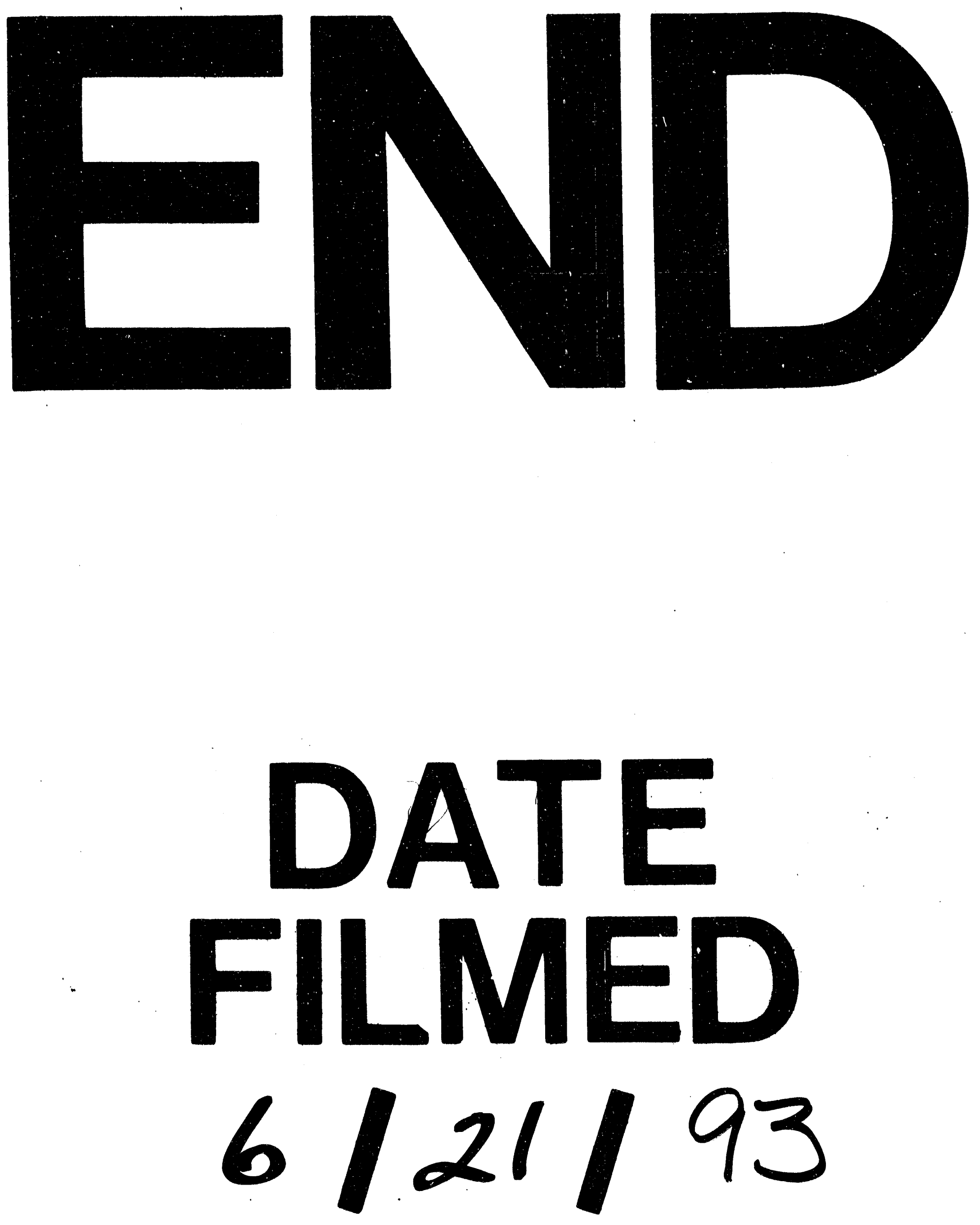